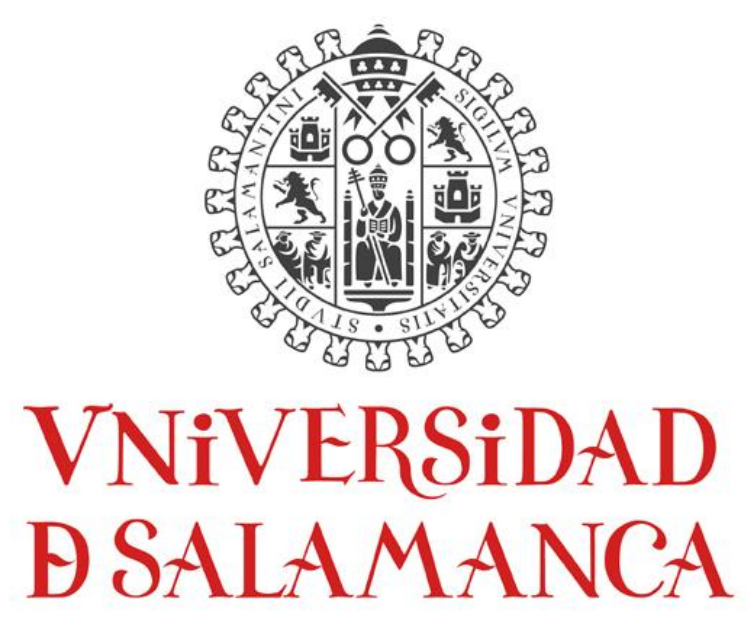

CAMPUS DE EXCELENCIA INTERNACIONAL

Tesis Doctoral

\title{
Efecto de la dexametasona sobre el mecanismo inflamatorio que subyace en el asma
}

Elena Marcos Vadillo

\author{
Directores \\ Dr. D. Ignacio Jesús Dávila González \\ Dra. Dña. Catalina Sofía Sanz Lozano \\ Dra. Dña. María Asunción García Sánchez
}

2016 


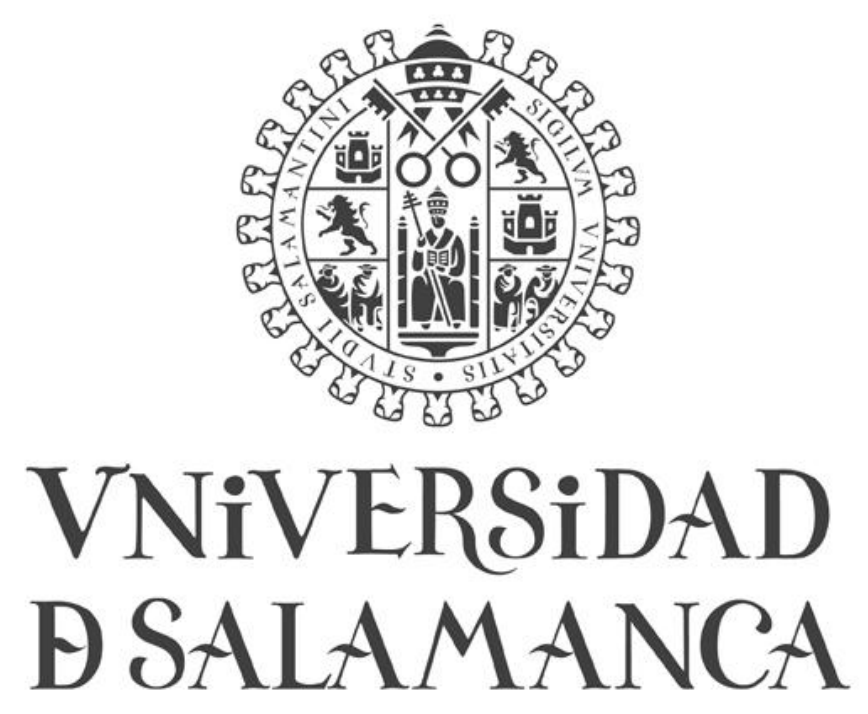

CAMPUS DE EXCELENCIA INTERNACIONAL

Tesis Doctoral

\section{Efecto de la dexametasona sobre el mecanismo inflamatorio que subyace en el asma}

Memoria presentada por Dña. Elena Marcos Vadillo para optar al grado de Doctora

Fdo: Elena Marcos Vadillo

2016 
El Prof. Dr. D. Ignacio Jesús Dávila González, Profesor Titular del Departamento de Ciencias Biomédicas y del Diagnóstico, la Profa. Dra. Dña. Catalina Sofía Sanz Lozano, Profesora Contratado Doctor del Departamento de Microbiología y Genética, y la Profa. Dra. Dña. María Asunción García Sánchez, Profesora Ayudante Doctor del Departamento de Ciencias Biomédicas y del Diagnóstico.

\section{CERTIFICAN:}

Que el trabajo titulado "Efecto de la dexametasona sobre el mecanismo inflamatorio que subyace en el asma", que presenta la licenciada en Biología Dña. Elena Marcos Vadillo ha sido realizado bajo nuestra dirección y reúne, a nuestro juicio, originalidad y contenidos suficientes para que sea presentado ante el Tribunal correspondiente y optar al grado de Doctora por la Universidad de Salamanca.

Y para que así conste y a los efectos oportunos, expedimos el presente certificado en Salamanca a 25 de Mayo de 2016. 
A David

A mis hermanas

A mis padres

... por su apoyo incondicional

... por quererme tanto 


\section{Agradecimientos}

Quisiera dar las gracias a toda la gente que de una forma $u$ otra ha hecho posible la realización de este trabajo.

En primer lugar, a mis directores de tesis, los doctores Ignacio Dávila González, Catalina Sanz Lozano y $M^{a}$ Asunción García Sánchez, por su profesionalidad, por su confianza, y por enseñarme cómo trabaja un buen equipo.

A la doctora María Isidoro García, por su implicación y dedicación en todo momento. Por guiarme en este proyecto.

A Choni y a Laura, porque, aunque no lo sepan, conocerlas me hizo mucho más fácil mi vida en Salamanca. A Laura por su eterna sonrisa, por su amabilidad, por su alegría. A Choni por todo, por enseñarme, por su tiempo, por apoyarme, por su amistad.

A Iñaki por sus charlas y su locura. A $M^{a}$ Paz por su cariño, por cuidarme. Los dos han sido un apoyo importante en esta tesis y en la residencia.

Al Servicio de Inmunoalergia, por acogernos a todos los que pasamos por allí. A Carmen, que nos soporta a todos y a Fernando por ayudarme con los ratones.

Al Servicio de Bioquímica, por enseñarme a trabajar, por los días de guardia, por los cafés en la salita. A mi tutora, Belén, y a mis compañeros residentes. A Virginia por hacer de R mayor cuando no lo era.

A mis padres, por creer en mí. Por apoyarme de forma incondicional, por ser un referente en mi vida. A mis hermanas porque las quiero. A María por sus puzles en la escalera. A Ana y a Fer, porque sé que están ahí. A Daniel y Lucía, porque sin darse cuenta, hacen que se me olvide todo.

A mi David, por esperarme siempre. Por comprenderme, por cuidarme, por ser mi complemento, por toda una vida.

Gracias. 
"Conserva celosamente tu derecho a reflexionar, porque incluso el hecho de pensar erróneamente es mejor que no pensar en absoluto".

Hipatia de Alejandría 
Índice

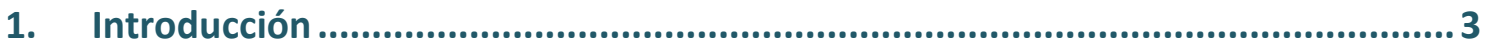

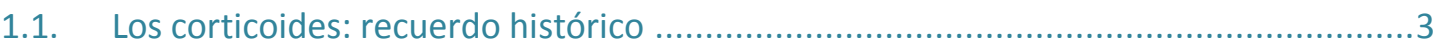

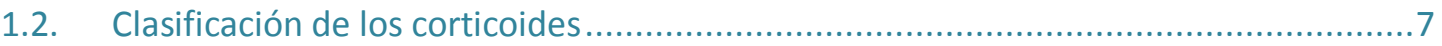

1.3. Mecanismo de acción de los glucocorticoides ........................................................13

1.3.1. Gen del receptor de glucocorticoides ..........................................................13

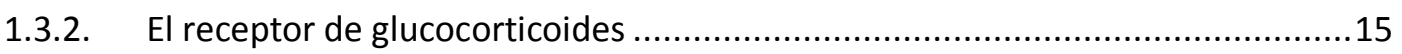

1.3.3. Elementos de Respuesta a Glucocorticoides (GRE) .......................................19

1.4. Genes relacionados con la acción de los corticoides..............................................21

1.4.1. Genes activadores de la respuesta inflamatoria .............................................21

1.4.2. Genes inhibidores de la respuesta inflamatoria..............................................24

1.4.3. Genes relacionados con la estabilidad del ARNm.............................................26

1.4.4. Genes relacionados con la remodelación de la cromatina ...............................27

1.4.5. Genes relacionados con la activación de apoptosis........................................28

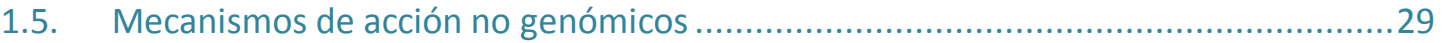

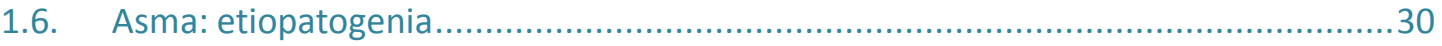

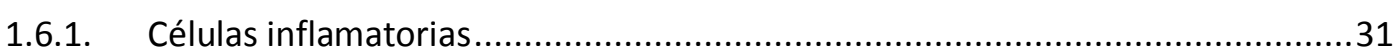

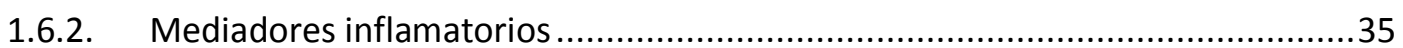

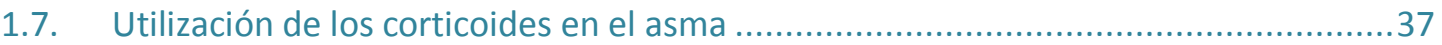

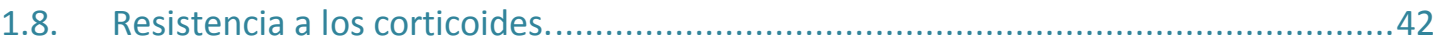

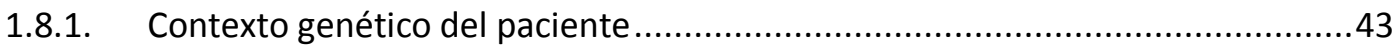

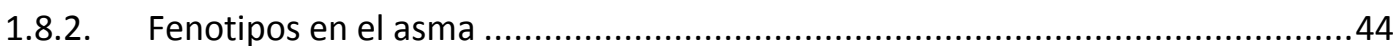

1.8.3. Fallo en la afinidad de GR, en la translocación nuclear, y en su unión a GRE .....46

1.8.4. Incapacidad para inhibir mecanismos proinflamatorios..................................47

1.8.5. Otras causas de resistencia a glucocorticoides. ...............................................48

1.9. El gen PTGDR y su importancia en las enfermedades alérgicas ................................48

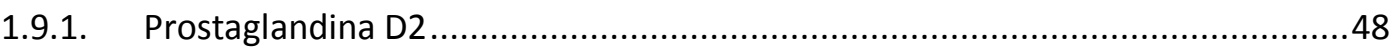

1.9.2. Receptores de la Prostaglandina D2 y su papel en el proceso inflamatorio ........51

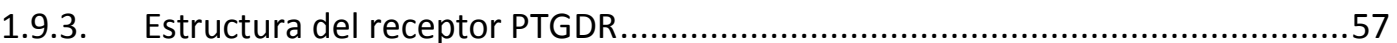

1.9.4. Estudios genéticos de asociación con las enfermedades alérgicas ....................59

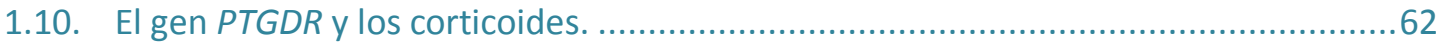

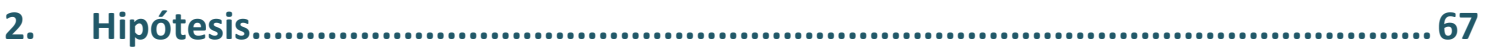

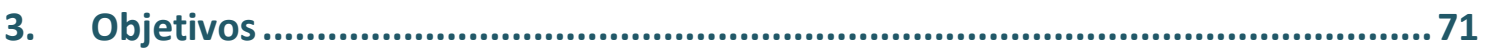

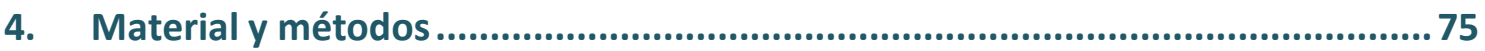

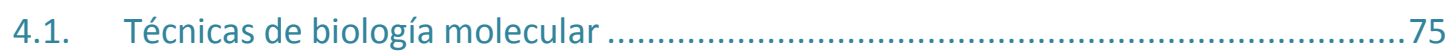




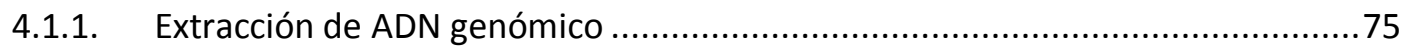

4.1.2. Discriminación alélica de CYP3A5 en cultivo celular........................................76

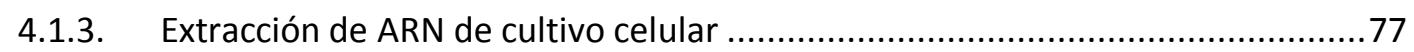

4.1.4. Extracción de ARN de tejido pulmonar de ratón ...............................................78

4.1.5. Síntesis de ADN complementario (ADNc) ....................................................79

4.1.6. Control de calidad de los ácidos nucleicos extraídos........................................80

4.1.7. Reacción en cadena de la polimerasa (PCR).................................................... 81

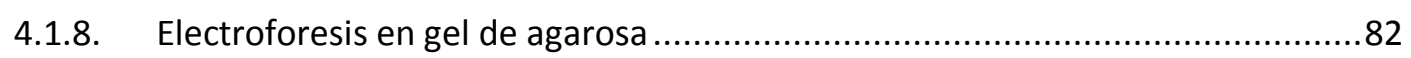

4.1.9. Purificación de los fragmentos amplificados por PCR......................................83

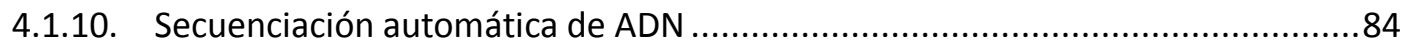

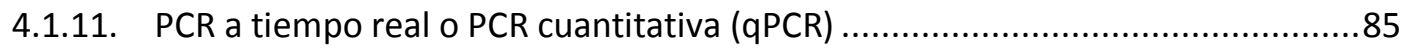

4.1.12. Diseño, síntesis y cálculo de la eficiencia de los cebadores .............................87

4.1.13. Estudio in silico de las variantes polimórficas del promotor de PTGDR .............90

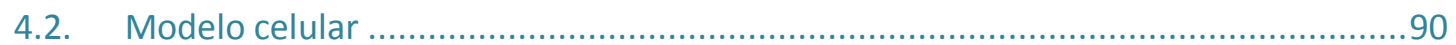

4.2.1. Selección de polimorfismos y generación de los insertos para clonación ...........90

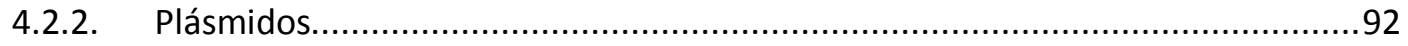

4.2.3. Obtención de ADN plasmídico ....................................................................... 98

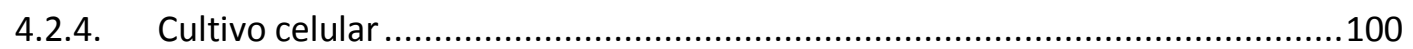

4.2.5. Transfección transitoria con lípidos catiónicos. Lipofección ..............................107

4.2.6. Ensayos de actividad promotora con gen reportero .....................................110

4.2.7. Ensayos de expresión génica con vectores de expresión..................................114

4.2.8. Ensayos de expresión de citocinas en cultivo celular ......................................116

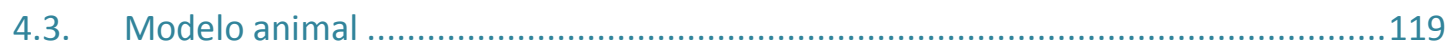

4.3.1. Desarrollo de un modelo animal de alergia/asma respiratoria ........................119

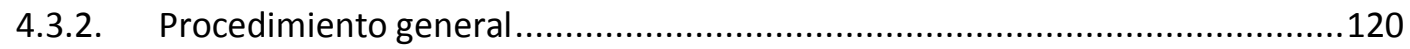

4.3.3. Modelo crónico de asma alérgica en ratón ...................................................123

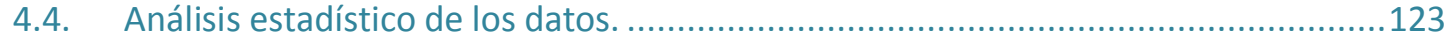

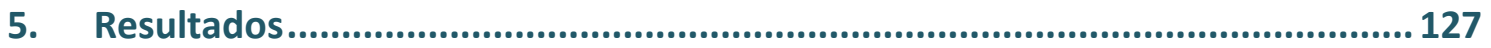

5.1. Desarrollo de un modelo de tratamiento con dexametasona en la línea celular

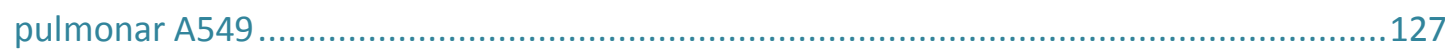

5.1.1. La línea celular A549 presenta una combinación haplotípica CTTT (-613, -549, -

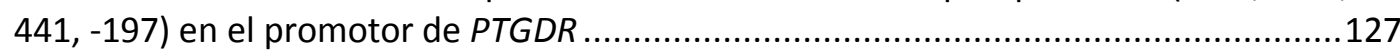

5.1.2. No se detecta expresión de PTGDR en la línea celular A549 ..........................127

5.1.3. La línea celular A549 presenta un genotipo GG para el polimorfismo 6986A>G

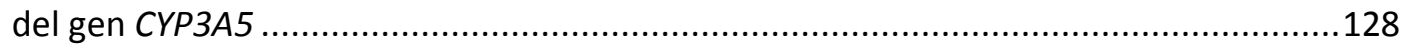

5.1.4. La dexametasona activa la expresión de CYP3A5 en la línea celular A549 ........128

5.2. Efecto de los polimorfismos en el promotor del gen PTGDR sobre su actividad promotora. Análisis del efecto del tratamiento corticoideo. 
5.2.1. La activación del promotor es más evidente a las 12 horas que a las 36 horas.

5.2.2. El haplotipo TCCT presenta la menor actividad promotora y CCCC la actividad más aumentada

5.2.3. La dexametasona produce un aumento de la actividad promotora.

5.2.4. Tras el tratamiento con dexametasona la variante TCCT mantiene el menor nivel de actividad mientras que la variante CTCT presenta el mayor nivel de actividad 134

5.3. Estudio del efecto de los polimorfismos en el promotor del gen PTGDR sobre su expresión génica. Análisis del efecto del tratamiento corticoideo

5.3.1. La presencia de polimorfismos en el promotor de PTGDR varía su expresión..136

5.3.2. El etanol, vehículo de la dexametasona, afecta al nivel de expresión de PTGDR

5.3.3. El efecto de la dexametasona sobre la expresión de PTGDR varía a lo largo del tiempo......

5.3.4. El efecto de la dexametasona sobre la expresión de PTGDR varía dependiendo de la combinación haplotípica presente en su promotor

5.4. Estudio in silico de los cambios en los factores de transcripción en cada una de las variantes del promotor del gen PTGDR

5.5. Análisis del efecto de la presencia de polimorfismos en el promotor de PTGDR sobre la expresión de citocinas.

5.5.1. La transfección de PTGDR en las células A549 modifica el patrón de expresión de la citocinas

5.5.2. La dexametasona produce una variación de la expresión de las citocinas en las células control

5.5.3. La dexametasona ejerce efectos diferentes según la variante transfectada. Las mayores diferencias a las 12 horas se observan en IP-10, RANTES, MIP-1b, IL-12, VEGF, IL6 e IL-8.

5.5.4. El tratamiento con dexametasona origina concentraciones diferentes de citocinas según la variante transfectada. Las mayores diferencias a las 36 horas se observan en MCP-1, IP-10, RANTES, Eotaxina e IFN- $\gamma$.

5.6. Desarrollo de un modelo múrido de asma alérgica crónica y evaluación del tratamiento con dexametasona ...............................................................166

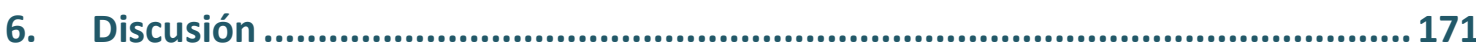

6.1. Modelo experimental en la línea celular A549 .......................................................171

6.1.1. Caracterización y expresión basal de PTGDR ..............................................171

6.1.2. Metabolización de glucocorticoides .............................................................172

6.2. Análisis de la actividad promotora de PTGDR y su respuesta a corticoides .............173

6.2.1. Influencia de los polimorfismos de PTGDR sobre su actividad promotora ........173

6.2.2. Influencia de los polimorfismos de PTGDR sobre la evolución temporal de su actividad promotora.

6.2.3. Efecto del tratamiento con glucocorticoides sobre la actividad promotora de PTGDR....... 
6.2.4. Influencia de los polimorfismos de PTGDR sobre su respuesta a glucocorticoides

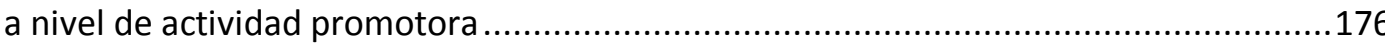

6.3. Análisis de la expresión de PTGDR y su respuesta a corticoides .............................177

6.3.1. Influencia de los polimorfismos de PTGDR sobre su expresión .......................177

6.3.2. Efecto del vehículo del corticoide sobre la expresión de PTGDR ......................180

6.3.3. Efecto del tratamiento con glucocorticoides sobre la expresión de PTGDR .....181

6.3.4. Influencia de los polimorfismos de PTGDR sobre su respuesta a glucocorticoides a nivel de expresión génica.

6.4. Influencia de los polimorfismos en el promotor de PTGDR sobre la unión de factores de transcripción.

6.5. Análisis de la expresión de citocinas y la respuesta a glucocorticoides .....

6.5.1. Influencia de PTGDR y la presencia de polimorfismos en su promotor sobre el patrón de expresión de citocinas.

6.5.2. Efecto del tratamiento con glucocorticoides sobre la expresión de citocinas en las células control.

6.5.3. Influencia de los polimorfismos de PTGDR sobre su respuesta a glucocorticoides a nivel de expresión de citocinas

6.6. Modelo experimental múrido de asma alérgica crónica y respuesta a

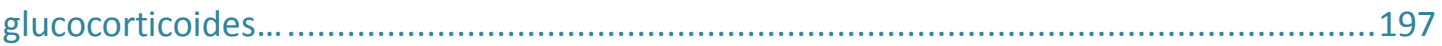

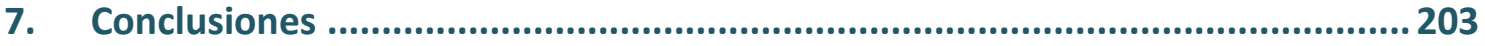

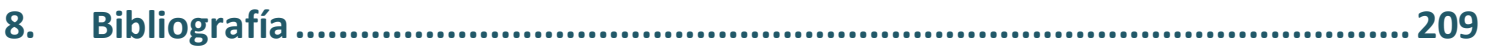

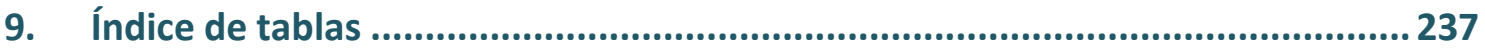

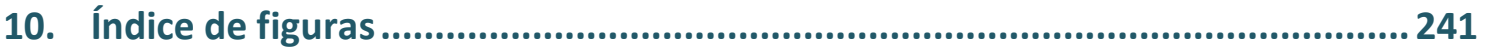

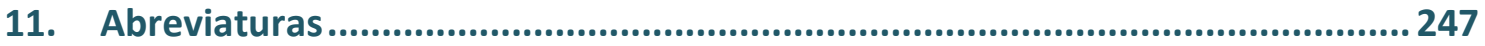





\section{INTRODUCCIÓN}

\subsection{Los corticoides: recuerdo histórico}

El término corticoide o corticosteroide (del latín cortex, corteza, y esteroide, del

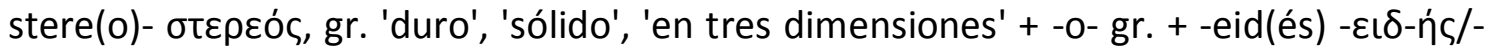
દ́ৎ gr. 'que tiene el aspecto de') hace referencia a un grupo de hormonas de tipo esteroideo con estructura policíclica (1), que se sintetizan en la corteza de las glándulas suprarrenales a partir del colesterol, y que también pueden elaborarse de forma sintética mediante una serie de modificaciones en su estructura básica que mejoran sus propiedades terapéuticas (2).

Aunque las glándulas suprarrenales fueron descritas por primera vez en 1563 por el médico italiano Bartolomeu Eustachi (3), no fue hasta el siglo XIX cuando se demostró su importancia a través de la publicación, en 1855, de la monografía “On the constitutional and local effects of desease of the Supra-renal Capsules" (Figura 1) escrita por Thomas Addison (1793-1860). En esta publicación, Addison puso de manifiesto la relación existente entre el estado de salud de once pacientes, que él mismo describía como "un estado general de languidez y debilidad, desfallecimiento en la acción del corazón, irritabilidad en el estómago y un cambio peculiar en la piel" y que evolucionaban a la muerte del individuo, con el hallazgo posterior de distintas alteraciones en las glándulas suprarrenales durante la autopsia (4). Estos estudios tuvieron gran reconocimiento internacional, y acabó denominándose "enfermedad de Addison" a la insuficiencia suprarrenal. 
Los experimentos realizados en animales a principios de siglo XX consiguieron demostrar que la extirpación de las glándulas suprarrenales provocaba una afección similar a la descrita por Thomas Addison. Además, el tratamiento con extracto de glándulas suprarrenales de ratones previamente adrenalectomizados lograba mermar los efectos provocados (5), por lo debía existir algún compuesto en estas glándulas que podría utilizarse en el tratamiento de la enfermedad de Addison.

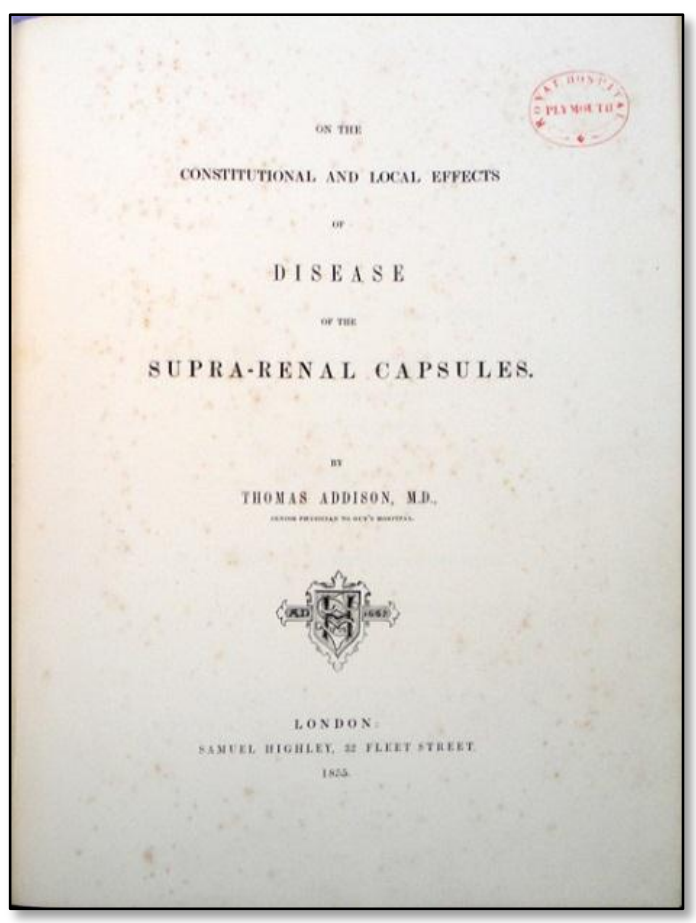

Figura 1: Publicación de Thomas Addison en 1855. Monografía sobre los efectos locales y constitucionales de las enfermedades de la corteza suprarrenal.

En 1929, el médico estadounidense Philip S. Hench (1896-1965), afirmó que debía existir una sustancia química específica, a la que denominó "sustancia X" que provocaba que pacientes con artritis reumatoide mejorasen cuando se quedaban embarazadas o cuando presentaban ictericia. Hench defendía que esta "sustancia X" no sólo tenía propiedades antirreumáticas sino también antialérgicas, con un efecto rápido pero transitorio (6). 
A principio de los años 30, casi de forma simultánea pero independiente, Edward C. Kendall (1889-1972) junto a su equipo en la Clínica Mayo (Rochester), y Tadeus Reichstein (1897-1996) en Suiza, lograron aislar una sustancia cristalina a partir de extractos de glándulas suprarrenales constituida por más de 30 compuestos (7). Ambos consiguieron purificar distintos componentes de esta sustancia comprobando los efectos de cada uno de ellos. De esta forma consiguieron aislar un elemento cristalino de la corteza suprarrenal, que Kendall denominó inicialmente compuesto $E, y$ que posteriormente se conocería como cortisona. Kendall demostró que el compuesto E y la sustancia $X$ de Hench eran lo mismo.

En los años posteriores, ambos grupos llegaron a la conclusión de que la estructura básica de estos compuestos suprarrenales era idéntica a un grupo de hormonas que ya se conocían en la época: los esteroides. En 1940 dos categorías de corticosteroides fueron identificadas, unas provocaban retención de sodio y fluidos (mineralocorticoides), mientras que otras se oponían al choque (shock) y a la inflamación (glucocorticoides) $(8,9)$.

Los procesos de purificación de los compuestos suprarrenales se llevaban a cabo mediante técnicas complicadas y con rendimientos muy pobres. Sin embargo, un hecho histórico impulsó de forma notable el desarrollo final de los corticosteroides y su introducción en la práctica médica. Durante la Segunda Guerra Mundial, y tras los acontecimientos de Pearl Harbor en 1941, el gobierno de Estados Unidos, instó al National Research Council al desarrollo de grandes cantidades de la hormona de la corteza adrenal para utilizarla en operaciones militares. Esta petición vino propiciada por los rumores que aseguraban que los pilotos de la Lufwaffe (fuerza aérea alemana 
de la época nazi) se inyectaban extracto de suprarrenales que les confería una resistencia al estrés, y particularmente a la hipoxia, lo que les permitía volar más alto, además de reducir la fatiga y aumentar la energía corporal. Estos rumores resultaron falsos, pero constituyeron un potente catalizador en la investigación de los corticoides (10).

En 1948, los grupos de trabajo de la clínica Mayo junto con la compañía farmacéutica Merck y Co., lograron producir la primera síntesis a gran escala del compuesto E o cortisona. En este año se trató por primera vez a una paciente afecta de artritis reumatoide con este compuesto, logrando una mejoría importante, que desaparecía al cesar el tratamiento. De esta forma, se introdujo el uso de los glucocorticoides en la práctica clínica, no sólo para pacientes con artritis reumatoide sino también a afectados por Lupus Eritematoso Sistémico, fiebre reumática o polimiositis (11).

Por el descubrimiento de la cortisona recibieron, en el año 1950, el Premio Nobel de Medicina los doctores Hench, Kendall y Reichstein. Desde entonces, el empleo de los corticoides en práctica médica es muy frecuente, no solo como tratamiento sustitutivo en la insuficiencia adrenocortical sino por sus efectos antialérgicos, antiinflamatorios e inmunosupresores (12).

En los años posteriores, muchos grupos empezaron a analizar y comprobar los efectos del tratamiento corticoideo, empezando a describirse los efectos secundarios que las terapias prolongadas provocaban en los pacientes. En las últimas décadas, los esfuerzos se han centrado en obtener derivados sintéticos de los glucocorticoides con mejores propiedades farmacológicas, intentando minimizar lo máximo posible la 
actividad mineralocorticoide. Así, mediante distintas modificaciones químicas de los corticoides naturales, como deshidrogenación, metilación, esterificación o halogenación con flúor o cloro, se ha obtenido toda una batería de compuestos con una acción antiinflamatoria mucho más potente que las hormonas originales, con actividad mineralocorticoide escasa, menos efectos secundarios y mayor vida media. La prednisona, prednisolona, metilprednisona, betametasona, hidrocortisona, o dexametasona (dexa) constituyen algunos ejemplos de glucocorticoides sintéticos utilizados actualmente $(13,14)$.

\subsection{Clasificación de los corticoides}

Las hormonas corticoideas son sintetizadas en la corteza de las glándulas suprarrenales, dos glándulas endocrinas situadas en los polos renales, con dos zonas diferenciadas: la corteza y la médula. En la médula se sintetizan las catecolaminas, y en la corteza los corticosteroides y las hormonas sexuales (15) (Figura 2).

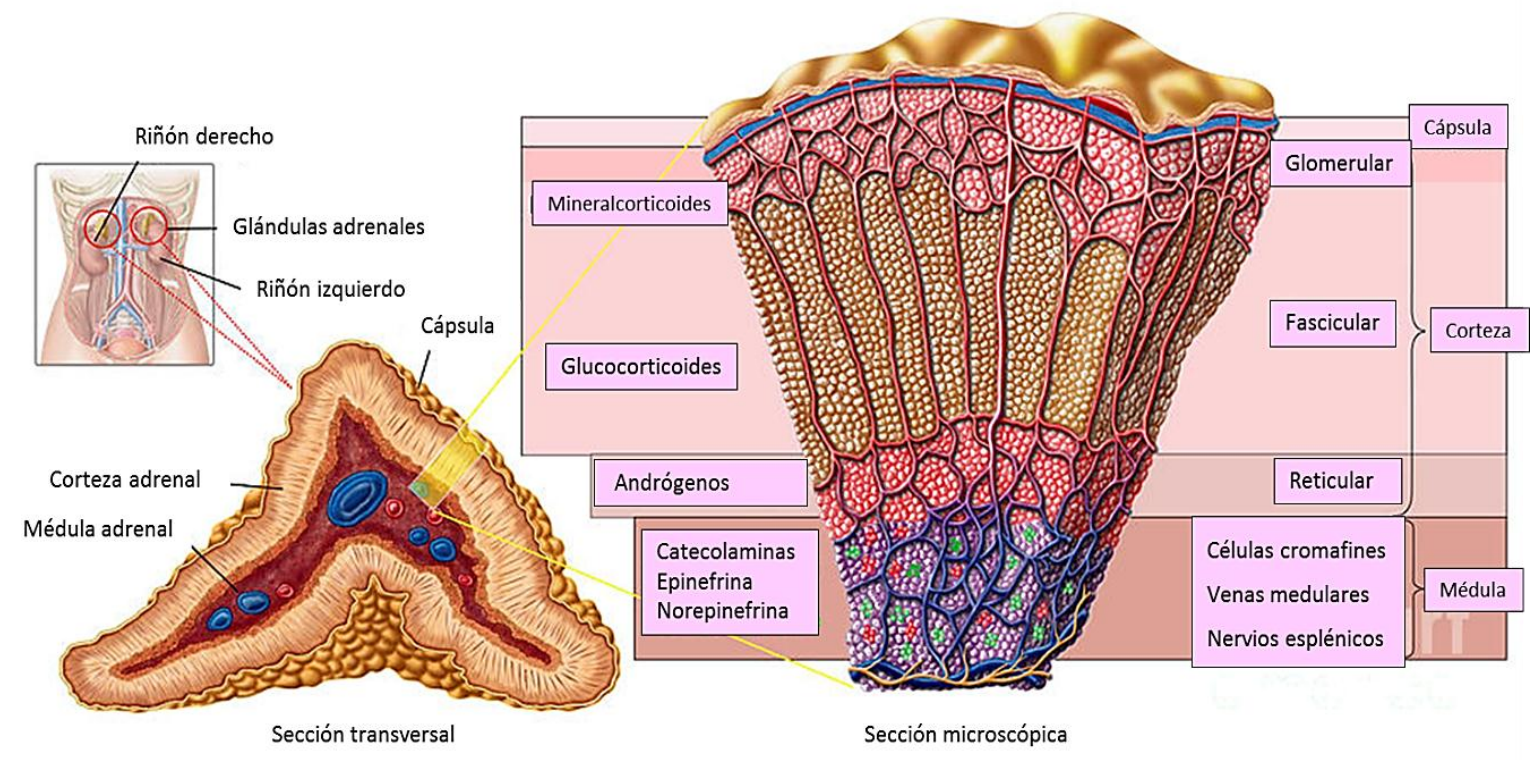

Figura 2: Anatomía de la glándula suprarrenal. Modificado de (16). 
La corteza de las glándulas suprarrenales está dividida en tres partes anatómicamente diferenciadas (17):

- La zona glomerular es la parte más externa y la responsable de la producción de mineralocorticoides. Está regulada por la angiotensina II, los niveles de potasio y la ACTH (hormona adrenocorticotropa o corticotropina).

- La zona fascicular es la zona central y en ella se produce la síntesis de glucocorticoides. Está regulada por la ACTH y, en menor medida, por algunas citoquinas y neuropéptidos (18).

- La zona reticular es la zona limítrofe con la médula adrenal. En ella se sintetizan los andrógenos, aunque también hay una ligera producción de glucocorticoides.

La síntesis de los glucocorticoides está regulada por el eje hipotálamo-hipófisissuprarrenal. Bajo la acción de diferentes estímulos, como el estrés, se produce la liberación del factor liberador de corticotropina (CRF) desde las neuronas del núcleo paraventricular (NPV) del hipotálamo, que produce a su vez la liberación de la hormona adrenocorticotropa o ACTH desde la hipófisis (o pituitaria) anterior. El destino principal de la ACTH circulante es la corteza suprarrenal, donde estimula la síntesis de glucocorticoides, principalmente cortisol (19). La liberación de cortisol sigue un ritmo circadiano regulado por pulsos desde el núcleo supraquiasmático hasta el NPV. El cortisol circulante accede a sus tejidos diana, como el hígado, el corazón o el tejido vascular, donde realiza sus funciones, y a su vez, autorregula su propia síntesis (20). En un mecanismo de retroalimentación negativa, el aumento de la concentración de cortisol en plasma inhibe la síntesis de ACTH y de CRF (Figura 3). 


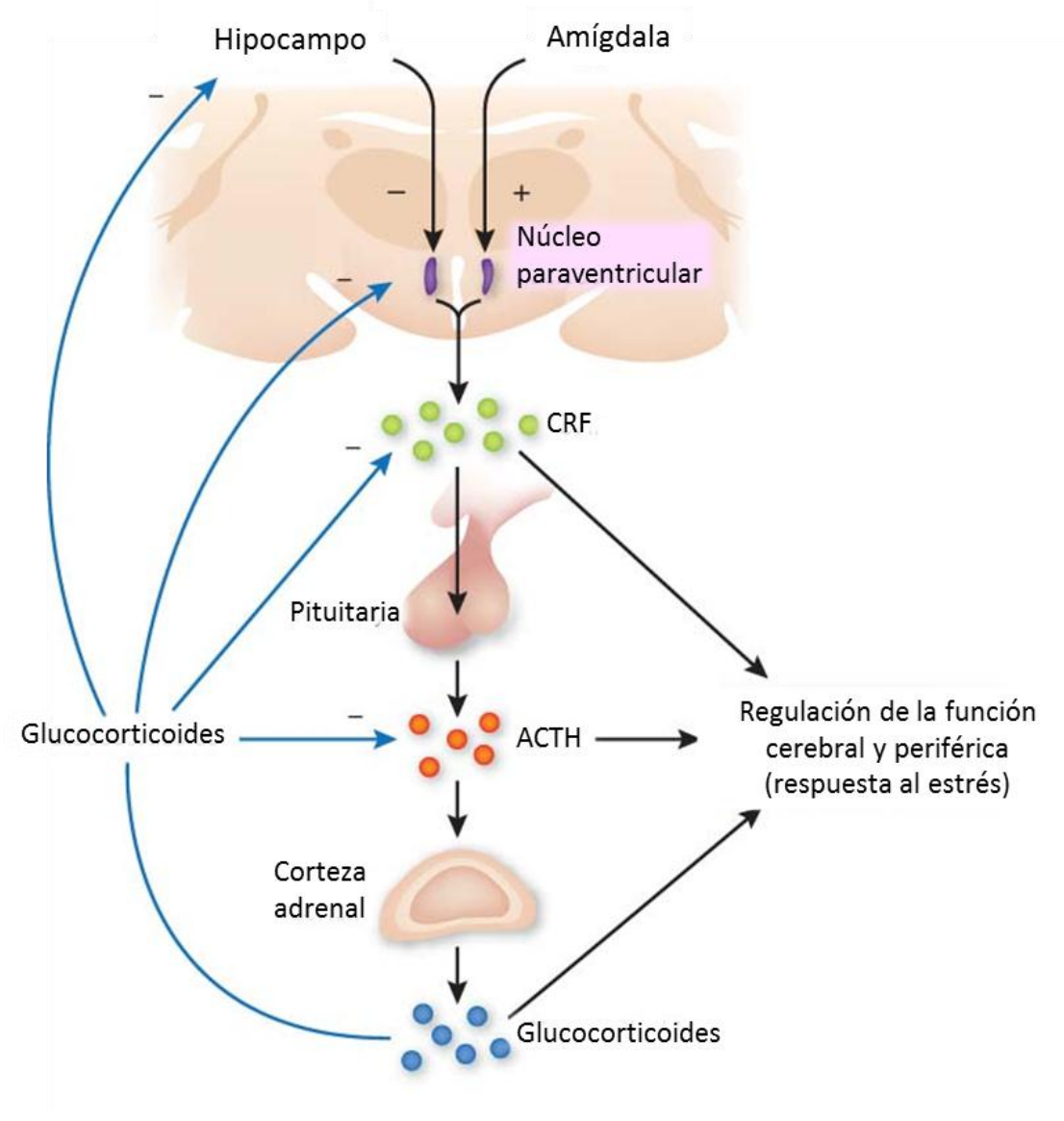

Figura 3: Sistema básico de regulación del eje hipotálamo-hipófisis-suprarrenal. Modificado de (21).

Todas las hormonas corticosuprarrenales son de naturaleza esteroidea, sintetizadas a partir del colesterol, con una estructura básica común consistente en cuatro anillos, denominados A, B, C y D, y formados por 17 átomos de carbono (ciclopentano-perhidrofenantreno) (Figura 4). Se diferencian en el grado de insaturación de sus carbonos y en la orientación espacial de las cadenas laterales (22). Tanto los mineralocorticoides como los glucocorticoides tienen una estructura final formada por 21 átomos de carbono, se consideran las hormonas más importantes de la corteza suprarrenal, y las responsables de sus funciones endocrinas. 


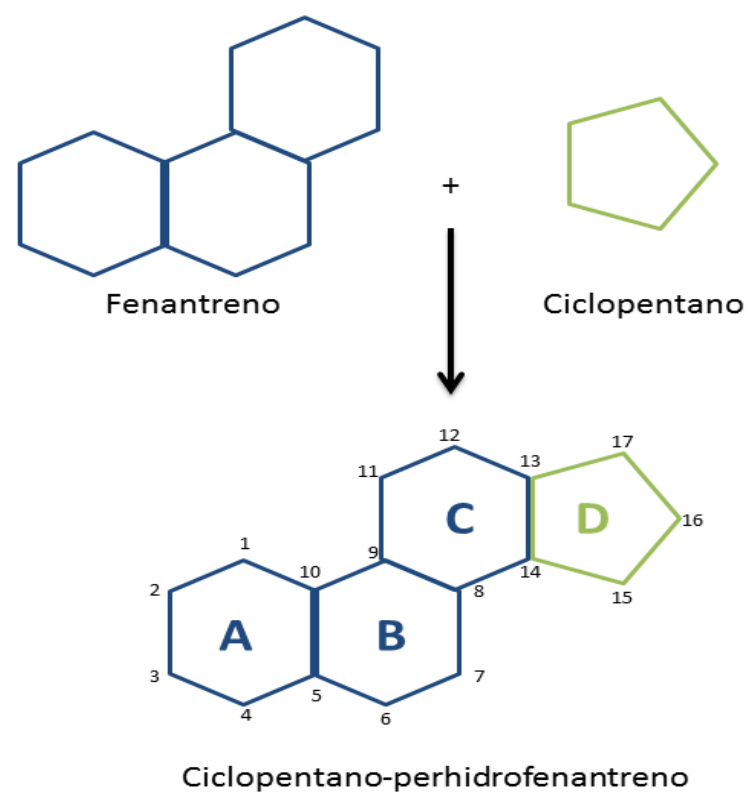

Figura 4: Estructura básica común de los esteroides. Anillo de ciclopentano-perhidrofenantreno.

Como se ha comentado anteriormente, según su actividad fisiológica, los corticoides se dividen en dos grupos principales, los mineralocorticoides y los glucocorticoides. Los mineralocorticoides, cuyo representante principal es la aldosterona, están implicados en la regulación del equilibrio hidroelectrolítico con la regulación de la homeostasis de sal y potasio, aunque también ejerce funciones en el balance ácido-base (23).

Los glucocorticoides (GC), por su parte, juegan un papel importante en el metabolismo de carbohidratos, proteínas y lípidos, en la respuesta inmune y en la respuesta al estrés. Ejecutan acciones musculoesqueléticas, regulan la secreción de otras hormonas como la hormona de crecimiento o la tirotropina (TSH), actúan sobre el sistema endocrino y metabólico, el sistema nervioso central y sobre el aparato gastrointestinal (24). Además, son potentes antiinflamatorios y regulan la función del sistema inmunitario, lo que les convierte en uno de los mayores descubrimientos 
terapéuticos de las últimas décadas en el tratamiento de las enfermedades autoinmunes y alérgicas. El glucocorticoide natural más representativo es el cortisol, aunque la corticosterona, una hormona de la vía mineralocorticoide, proporciona casi el $4 \%$ de la actividad glucocorticoide total (25).

Los corticoides de síntesis poseen una estructura similar a los naturales pero con algunos cambios como la introducción de dobles enlaces, la incorporación de moléculas de flúor o cloro y/o la presencia de un radicales - $\mathrm{OH}$ o-CH3 (26) (Figura 5). La introducción de un doble enlace adicional entre los carbonos C-1 y C-2 del cortisol en todos los corticoides sintéticos incrementa de forma selectiva la actividad glucocorticoide y antiinflamatoria. De hecho, los compuestos sintéticos presentan mayor potencia glucocorticoide, pierden actividad mineralocorticoide y tienen mayor vida media.

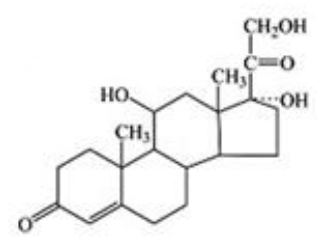

Cortisol

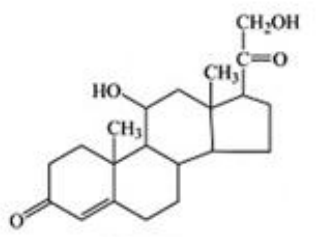

Corticosterona

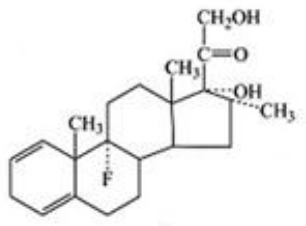

Dexametasona

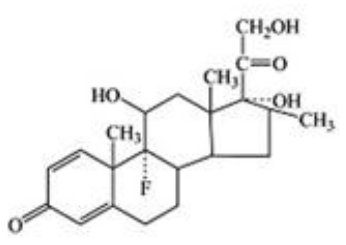

Betametasona

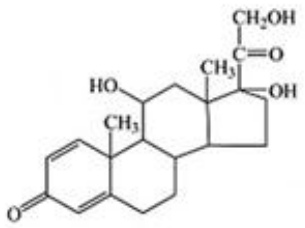

Prednisolona

Figura 5: Estructura molecular de algunos corticoides naturales y sintéticos. 
Los corticoides se clasifican según la combinación entre su potencia y la duración del efecto terapéutico (10). La potencia de la acción glucocorticoide y mineralocorticoide de un compuesto se establece, de forma generalizada, en referencia a la de la hidrocortisona o cortisol, al que se le confiere el valor 1 . A medida que se han ido desarrollando los nuevos corticoides sintéticos, se ha ido perdiendo la actividad mineralocorticoide, debido a las diferentes modificaciones químicas, fundamentalmente a la halogenación, y ha ido aumentando la vida media del fármaco. Así, los corticoides de primera generación, prednisona y prednisolona, que se obtienen por la introducción de un doble enlace en C1-C2, tienen una actividad mineralocorticoide mayor, mientras que los corticoides de segunda generación, como la betametasona y la dexametasona, carecen completamente de actividad mineralocorticoide y cuentan con una actividad glucocorticoide más potente. La introducción de un flúor en posición 9 y de un $-\mathrm{OH}$ en posición 16 de la molécula de prednisona da lugar a la síntesis de triamcinolona, en la que el efecto de retención de sal es prácticamente nulo (27). De acuerdo con la duración de la acción del corticoide se clasifican como de acción corta, con una duración de 6-12 horas, de acción intermedia si la duración está entre 12 y 36 horas, o de duración prolongada en caso de un efecto que dure entre 36-72 horas (14) (Tabla 1). 
Tabla 1: Clasificación de los glucocorticoides. Modificado de (28).

\begin{tabular}{|ccccc|}
\hline & $\begin{array}{c}\text { Potencia } \\
\text { glucocorticoide }\end{array}$ & $\begin{array}{c}\text { Potencia } \\
\text { mineralocorticoide }\end{array}$ & $\begin{array}{c}\text { Duración de } \\
\text { la acción (h) }\end{array}$ & $\begin{array}{c}\text { Dosis } \\
\text { equivalente } \\
\text { (mg) }\end{array}$ \\
\hline Cortisol & 1 & Acción corta & & \\
\hline Cortisona & 0,8 & 0,8 & $6-12$ & 20 \\
\hline Prednisona & 4 & Acción intermedia & & 25 \\
\hline Prednisolona & 5 & 0,3 & $12-36$ & 5 \\
\hline Triamcinolona & 5 & 0,3 & $12-36$ & 5 \\
\hline Metilprednisolona & 5 & 0 & $12-36$ & 4 \\
\hline & & 0 & $12-36$ & \\
\hline Dexametasona & 30 & Acción larga & & 0,75 \\
\hline Betametasona & $25-40$ & 0 & $36-72$ & 0,6 \\
\hline
\end{tabular}

\subsection{Mecanismo de acción de los glucocorticoides}

Debido a su estructura molecular, los glucocorticoides son solubles en lípidos y pueden penetrar fácilmente en el interior de las células diana atravesando la bicapa lipídica de la membrana celular. Una vez dentro, interaccionan con su receptor específico, el receptor de glucocorticoides (GR), que pertenece a la familia de receptores nucleares, entre los que se incluyen los receptores del ácido retinoico, de las hormonas sexuales, la vitamina $D$, y las hormonas tiroideas (29).

\subsubsection{Gen del receptor de glucocorticoides}

El gen que codifica el receptor de glucocorticoides, $G R$, también denominado NR3C1 (Nuclear Receptor Subfamily 3, Group C, Member 1), GCCR o GCR, se localiza en 
el brazo largo del cromosoma 5, en la región 5q31.3 (Figura 6), y consta de 9 exones que por procesamiento (splicing) alternativo dan lugar a distintas isoformas, entre las que destacan GRa y GRß. Además de estas dos isoformas se han descrito otras variantes generadas también mediante procesamiento alternativo, como GRy, GR-A o GR-P (30). Recientemente, se ha descrito un nuevo mecanismo de generación de variantes denominado "por inicio alternativo de la traducción" que ha permitido describir hasta 8 variantes dentro de la isoforma GRa, cada una de ellas más acortada (31).

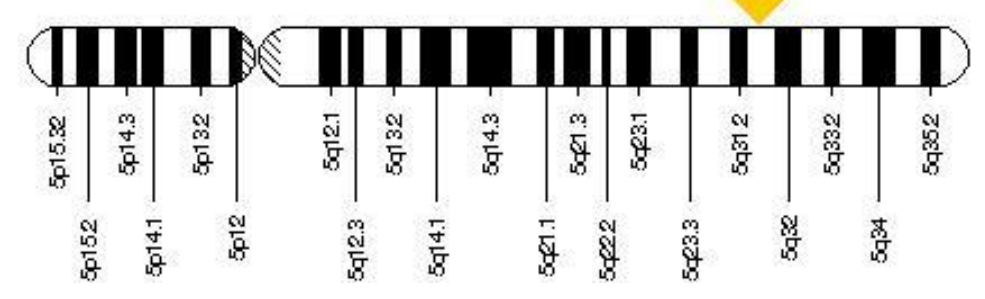

Figura 6: Localización del gen del receptor de glucocorticoide en el cromosoma 5. Se indica con una flecha amarilla la posición del gen.

Las isoformas de $G R$, $\alpha$ y $\beta$, comparten secuencia hasta el aminoácido 727 , a partir del cual GR $\alpha$ presenta 50 aminoácidos adicionales, y GR $\beta$ otros 15 aminoácidos adicionales no homólogos a los de GR (Figura 7). Mientras GR $\alpha$ actúa como un factor de transcripción dependiente de ligando, GRß, con una expresión mucho menor que GR $\alpha$, se une al ADN pero no une glucocorticoides (32) y se localiza constitutivamente en el núcleo. GRß actúa como un inhibidor de la acción de activación génica llevada a cabo por $\mathrm{GR} \alpha$, y se ha comprobado en cultivos celulares que la sobreexpresión de GR $\beta$ actúa como regulador negativo de la transcripción mediada por GR $\alpha$. Además, GRß estimula la producción de citoquinas proinflamatorias, como TNF- $\alpha$ e IL-1. Se han 
propuesto como mecanismos de antagonismo la competición por la unión al elemento de respuesta, la competición por los elementos correguladores de la transcripción y la formación de heterodímeros inactivos $\mathrm{GR} \alpha / \mathrm{GR} \beta$ (33).

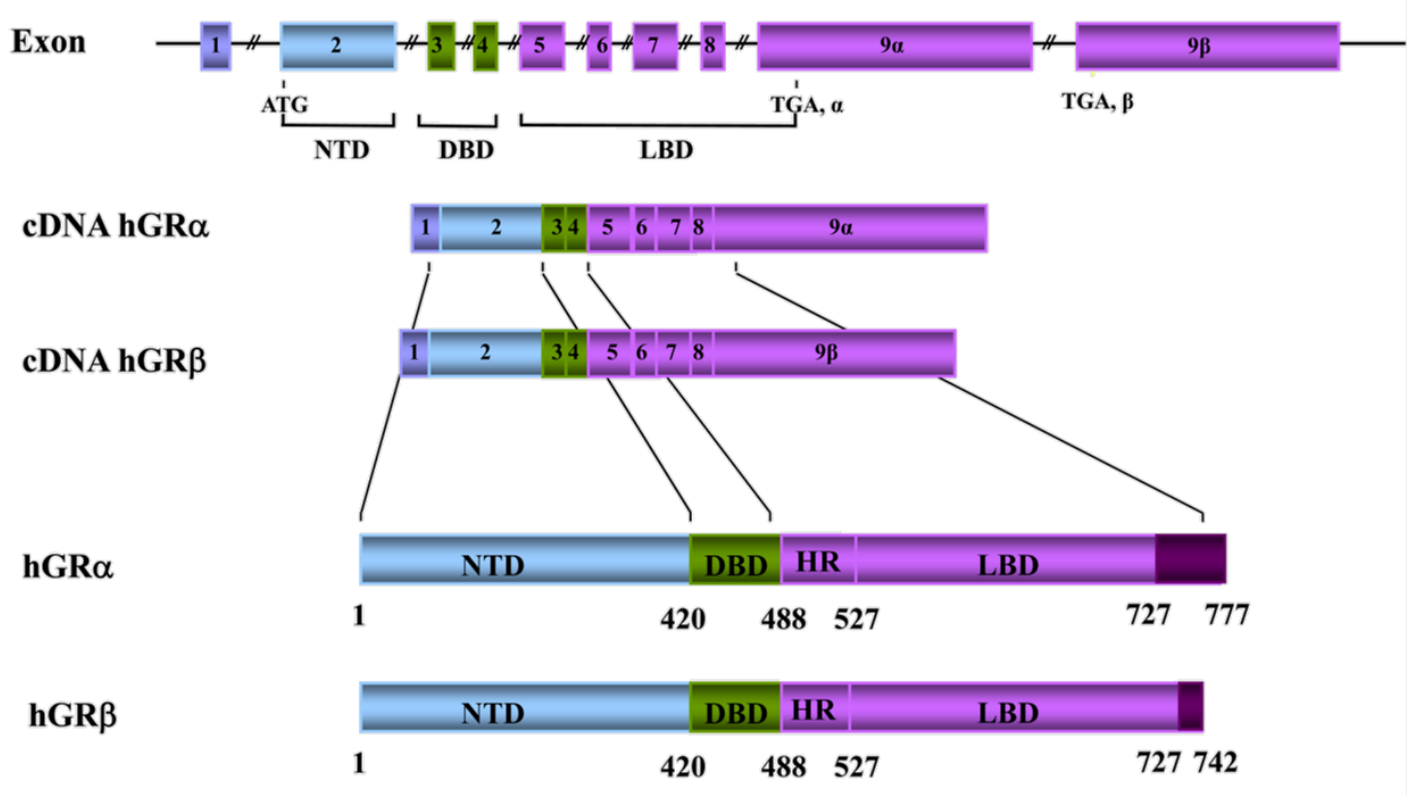

Figura 7: Isoformas del receptor de glucocorticoide GR $\alpha$ y GRß (34).

\subsubsection{El receptor de glucocorticoides}

El GR es una proteína modular de $92 \mathrm{kDa}$ con tres dominios (Figura 8). El dominio amino-terminal (NTD) contiene un dominio de transactivación (AF-1) desde el aminoácido 77 al 262, independiente de ligando, y responsable de la interacción entre el receptor y las moléculas necesarias para iniciar la transactivación, como coactivadores (SWI/SNF, pCIF, GRIP), moduladores de la cromatina (CBP/p300, P/CAF, SRC-1), y factores de transcripción como la propia RNA polimerasa II, TBP y TAFIls. A continuación de este primer dominio, se encuentra el dominio de unión al ADN (DBD), que abarca desde el aminoácido 420 al 480. Este dominio DBD es el responsable de la 
unión a la región promotora de los genes diana a través de dos motivos en dedos de zinc (35). Es el dominio más conservado en los receptores de esteroides y también contiene dominios importantes para la dimerización del receptor y la translocación nuclear. Por último, unido al dominio DBD por una región bisagra que aporta flexibilidad al receptor y que también está implicada en la dimerización, se encuentra el dominio de unión al ligando (LBD). Este último dominio es importante en la activación de GRa por el glucocorticoide y, además, contiene un segundo dominio de transactivación (AF-2) que, en este caso, a diferencia de AF-1, es dependiente de ligando. EI LBD proporciona el sitio de unión a proteínas del choque térmico y otros coactivadores. Tanto el dominio de unión a ADN como el domino de unión a ligando son esenciales en el proceso de translocación del receptor al núcleo y cada uno contiene una señal de localización nuclear, NLS1 y NLS2, respectivamente (34).

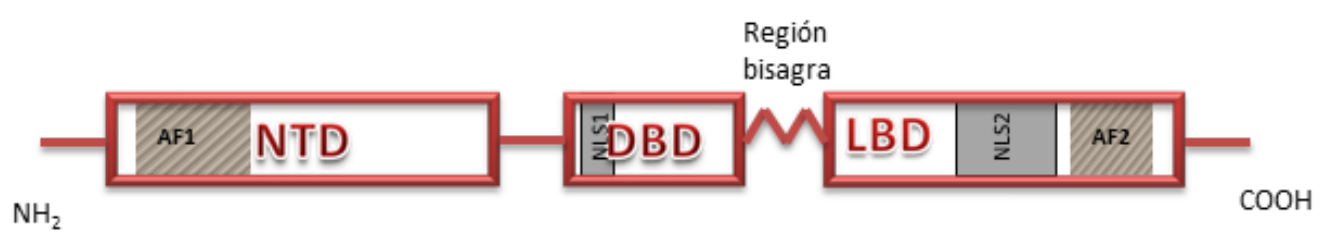

Figura 8: Estructura esquemática del receptor de glucocorticoides.

En ausencia de ligando, el receptor de glucocorticoides se encuentra formando un complejo multienzimático hetero-oligomérico junto a proteínas chaperonas o acompañantes (Hsp90, Hsp70, Hsp50), p23, inmunofilinas de masa molecular elevada (FKBP50, FKBP51, FKBP52, Cyp40) (36), varias proteínas de transmisión de señales (Scr, Raf-1), y algunas proteínas de la familia de las importinas (37). Todas ellas desempeñan un papel clave en la regulación de la unión entre el ligando y el receptor, y son 
responsables de la localización citoplasmática del receptor cuando no está presente el ligando, así como de su transporte al núcleo cuando es activado por glucocorticoides. Hsp90 permite la retención citoplasmática del receptor, al bloquear las dos secuencias de localización nuclear que posee el receptor de glucocorticoide. Por su parte, el complejo Hsp90, Hsp70 y Hsp40 unido al GR hace accesible el sitio de unión al ligando a las moléculas de glucocorticoide $(38,39)$ (Figura 9).

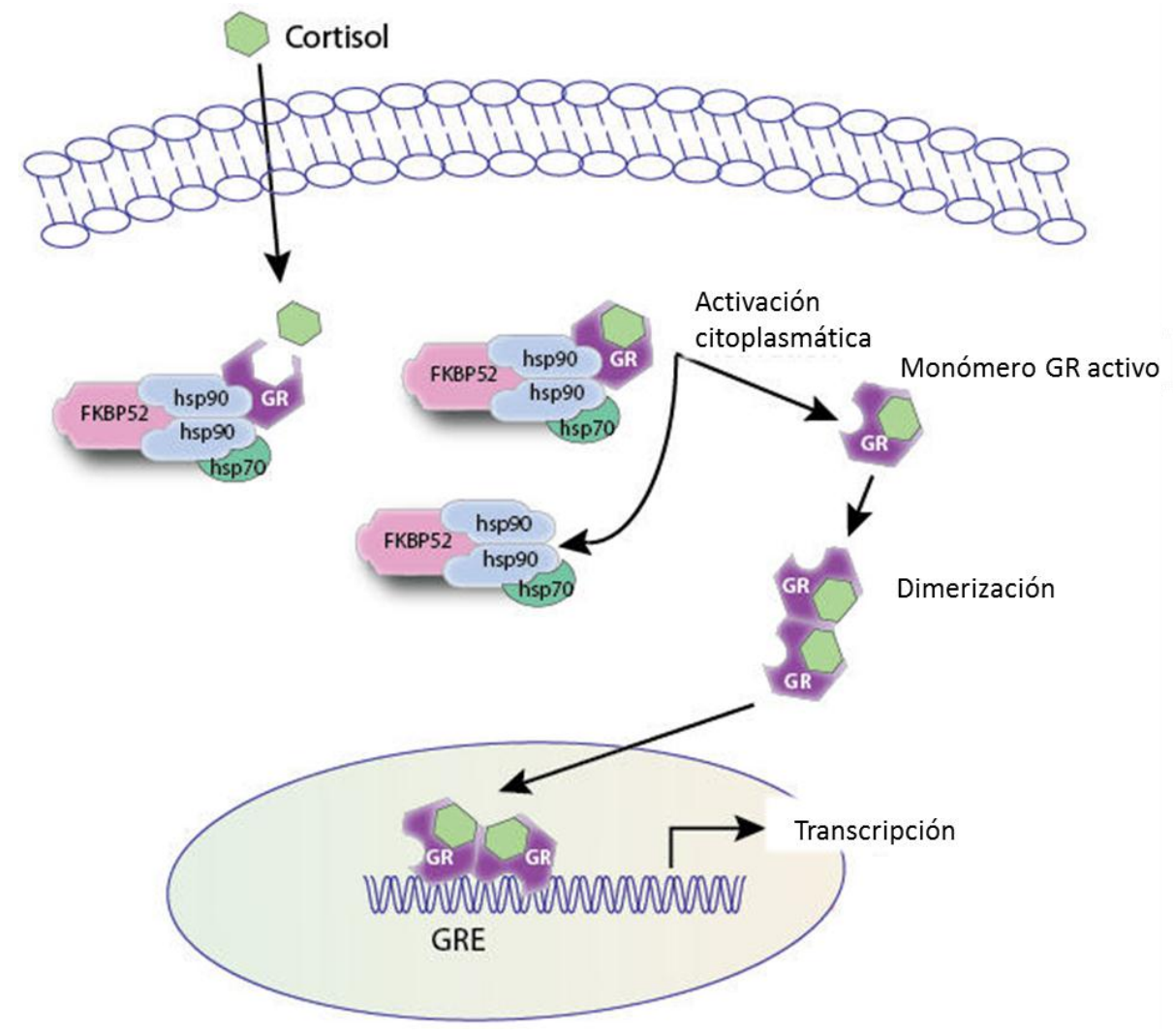

Figura 9: Activación del receptor de glucocorticoide por unión del ligando. Modificado de (40).

Algunos autores sostienen que la disociación de este complejo multiproteico tiene lugar inmediatamente después de la unión del receptor al ligando mediante un cambio conformacional producido por dicha unión. Otros, en cambio, sostienen que Hsp90 no debe disociarse de una forma tan inmediata puesto que la asociación Hsp90.GR·GC es aún necesaria para el transporte del receptor al interior nuclear. 
Según esto, el proceso de transformación de los receptores corticoideos debería ocurrir en un paso subsiguiente al retrotransporte, aunque previo a la unión del receptor a sus secuencias específicas en el ADN. El proceso de transformación conformacional debería ocurrir, por tanto, en el nucleoplasma (41).

El complejo activado GR·GC interacciona con proteínas del citoesqueleto, como la importina- $\alpha$ y la importina- $\beta$, y es transportado al núcleo donde ejerce su acción. Una vez que el receptor se separa de la molécula de glucocorticoide, es expulsado de nuevo al citoplasma mediante la participación de distintas proteínas, como la calreticulina y la exportina-1 (CRM1 o XPO1). El flujo entre el núcleo y el citoplasma también está controlado por la presencia de una señal de retención nuclear (NRS) en el receptor de glucocorticoide. Esta señal NRS se situaría en la región bisagra del GR y reprimiría la exportación a través de la vía de exportación nuclear dependiente de CRM1. Mientras que la importación del GR·GC al interior nuclear es un proceso rápido, la exportación de vuelta al citoplasma ocurre de forma lenta (42).

Una vez en el interior nuclear, el complejo GR.GC lleva a cabo sus funciones antiinflamatorias mediante acciones genómicas y no genómicas que se traducen en la activación de la transcripción de genes antiinflamatorios, así como en la represión de moléculas proinflamatorias. Mientras que las acciones genómicas son lentas (entre horas y días), los efectos no genómicos de los glucocorticoides son muy rápidos (minutos) (43). Se estima que los glucocorticoides influyen directa o indirectamente, en la transcripción de aproximadamente el $1 \%$ del genoma (44). 


\subsubsection{Elementos de Respuesta a Glucocorticoides (GRE)}

Tras la unión con el ligando, el receptor de glucocorticoides se comporta como un factor de transcripción que reconoce y se une a secuencias consenso denominadas "Elementos de Respuesta a Glucocorticoides" (GRE), situadas en la región promotora de diversos genes. Estos elementos de respuesta se pueden clasificar en varios tipos: GRE simples, son los GRE "convencionales"; GRE compuestos, la interacción del GR con el ADN depende de otros factores de transcripción y puede realizarse en forma de monómero; y GRE que precisan amarre (tethering), en cuyo caso el GR no interactúa directamente con el ADN, sino que lo hace a través de interacciones proteína-proteína con otros factores de transcripción (Figura 10). En todos los casos, el GR puede regular la expresión génica negativa o positivamente (45), por lo que, además, se puede hablar de GRE positivos o negativos. En el caso de los GRE simples, cuando se produce la activación de la expresión génica es necesaria la unión del GR en forma de homodímero, mientras que cuando provocan la inhibición de la expresión, se habla entonces de GRE negativos ( $\mathrm{nGRE}$ ), la unión del GR se realiza en forma de monómero. Aparte de esto, los GR pueden unirse a los GRE de tal forma que su unión impida la unión a este elemento de respuesta de otro factor de transcripción. Es este último caso se habla de un GRE competitivo.

Estos elementos de respuesta a glucocorticoides, son palíndromos invertidos hexaméricos separados por tres pares de bases, PuGNACAnnnTGTNCPy, donde cada molécula de GR se une a uno de los palíndromos (34) a través de su estructura DBD en dedo de zinc. Este GRE puede diferir entre promotores en cuanto a secuencia, número de copias, y localización relativa en el promotor (en relación con la caja TATA o con 
otros sitios de unión de factores de transcripción), regulando la especificidad y la magnitud de la respuesta (43).

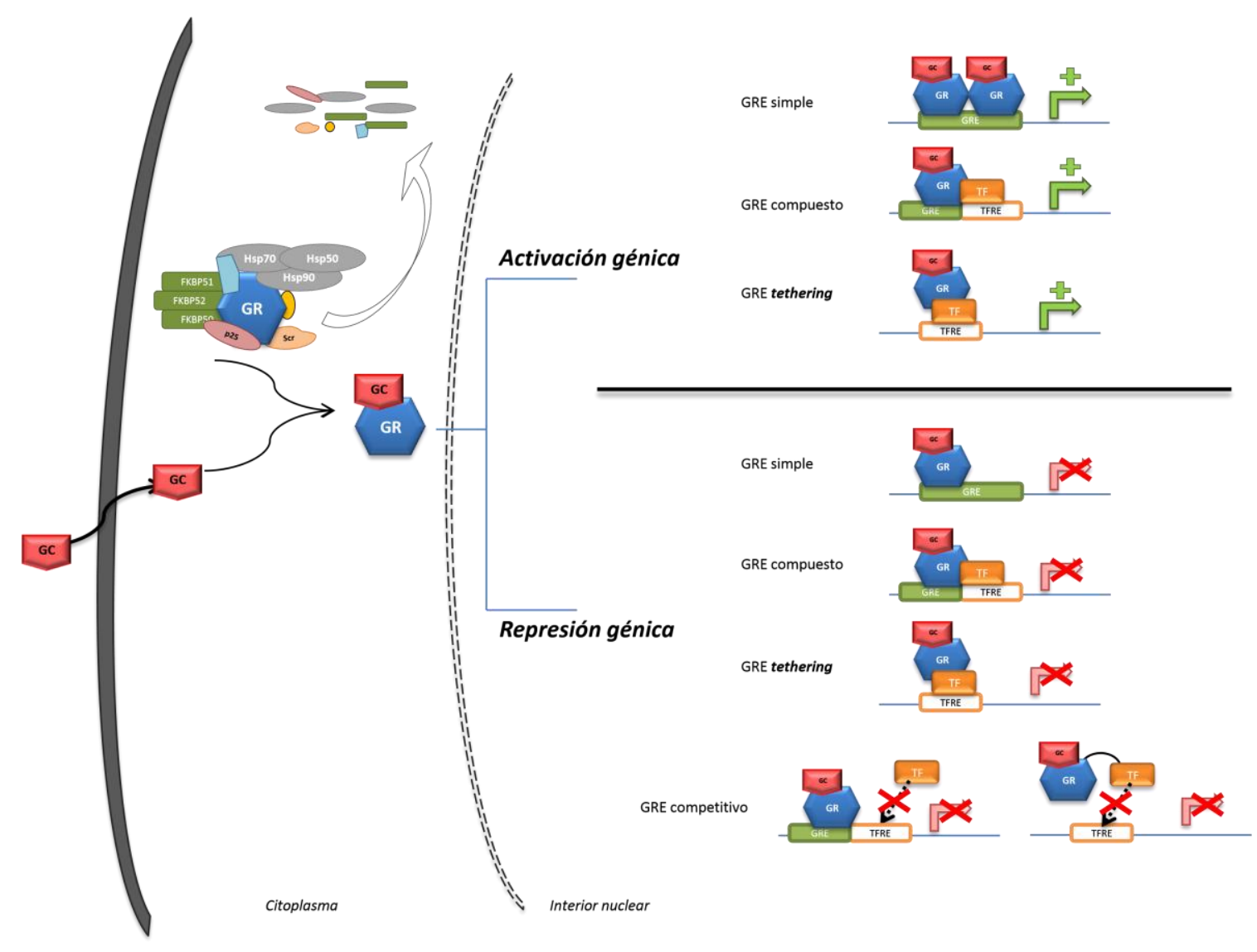

Figura 10: Acción del GR a través de los elementos de respuesta a glucocorticoide. GC: glucocorticoide, GR: receptor de glucocorticoide, GRE: elemento de respuesta a glucocorticoides, TF: factor de transcripción, TFRE: elemento de respuesta a factor de transcripción.

La unión al ADN del GR induce cambios conformacionales en el dominio AF1, de manera que las interacciones entre la secuencia de ADN y el acoplamiento alostérico entre DBD y AF1 desempeñan un papel esencial en la actividad de GR y en su función. Además, el domino AF2 interacciona con distintos péptidos correguladores cuando se une a distintas secuencias (46). La secuencia de aminoácidos NTD que flanquean AF1 pueden influir en los procesos de transmisión de señales (47). 
En estudios recientes, se postula la energética de la unión al ADN como el factor dominante para la actividad transcripcional específica de secuencia del GR, por lo que la regulación génica estaría básicamente bajo regulación termodinámica (48).

\subsection{Genes relacionados con la acción de los corticoides}

\subsubsection{Genes activadores de la respuesta inflamatoria}

Muchos de los efectos antiinflamatorios de la terapia corticoidea son atribuidos a la inhibición directa de los factores de transcripción AP-1 (Activator Protein-I) y NF-KB (Nuclear Factor kappa B). Estos factores de transcripción son responsables de la activación de genes de citoquinas, quimiocinas y moléculas de adhesión implicados en la inflamación como son IL-1 $\beta$, TNF- $\alpha$, IL-2, IFN- - , IL-6, IL-12, RANTES, VCAM-1, ICAM-1, E-selectina, COX-2 e iNOS, entre otras.

\section{- Factor de transcripción AP-1}

AP-1 es un activador transcripcional de numerosos genes inflamatorios, además de estar involucrado en procesos de proliferación celular, diferenciación y apoptosis. Engloba a una serie de familias proteicas como Jun, Fos, ATF, JDP y MAF, y puede presentarse en forma de homo y heterodímeros, siendo el complejo AP-1, compuesto por dímeros c-Fos/c-Jun, el más abundante en el interior celular. Determinadas citoquinas proinflamatorias, como el TNF- $\alpha$ y la IL-1 $1 \beta$, activan la formación de estos heterodímeros mediante la activación de la cinasa MAP c-Jun N-terminal (JNK), que fosforila la subunidad c-Jun favoreciendo su dimerización con c-Fos. El complejo GC.GR puede inhibir o modificar la actividad de AP-1 de varias formas. Por un lado, puede 
interactuar directamente con la subunidad c-Jun reprimiendo la expresión génica mediada por AP-1; esta modulación puede ser recíproca, y, del mismo modo, c-Jun puede unirse físicamente a GR e inhibir la activación mediada por él (33). Por otro lado, el receptor de glucocorticoide puede prevenir la activación de c-Jun mediante la activación de la expresión de MAPK fosfatasa-1 (MKP-1), que inhibe a JNK.

\section{- Factor de transcripción NF-KB}

El NF-KB es un factor de transcripción que desempeña un papel principal en la amplificación de las respuestas inflamatoria e inmune, y engloba a un grupo de proteínas de la familia REL. El heterodímero formado por p50 y p65 (RelA) es la forma de presentación más abundante. El NF-KB se encuentra inactivado en el citoplasma celular por la acción de la proteína inhibitoria I-kB, que impide su translocación al núcleo. En respuesta a citoquinas proinflamatorias, como TNF- $\alpha$, IL-1 13, IL-2, IL-17 y GM-CSF, se activa una cascada de cinasas que termina con la degradación de la molécula I-KB por el proteasoma, lo que conlleva a la activación del NF-KB. De forma análoga a lo que ocurre con AP-1, el GR puede reprimir al NF-KB por interacción física con la subunidad p65/RelA, y, además, por activación de la transcripción génica de I-KB (49). El antagonismo parece ser mutuo.

\section{- Factor de transcripción GATA3}

Por otro lado, los GC suprimen las células Th2, y su producción de citoquinas, mediante la inhibición del factor de transcripción GATA3, que regula la transcripción de genes de citoquinas Th2. El factor de transcripción GATA3 es esencial para la expresión de IL-4, IL-5 e IL-13. En los linfocitos T, GATA3 está situado en el citoplasma, 
y tras su activación, es fosforilado por p38MAPK y translocado al núcleo por la importina $\alpha$. Los GC inhiben la función de GATA3 mediante inhibición de su transporte al núcleo (bloqueando la importina a) y por inhibición de p38MAPK mediante la inducción de MKP-1 (50).

\section{- Ruta de transducción de señales MAP cinasas (MAPK)}

Las rutas de transducción de señales a través de las proteínas MAP (Mitogenactivated protein)-cinasas son esenciales en la respuesta inflamatoria, puesto que activan los factores de transcripción AP-1 y NF-KB, y regulan de la estabilidad del ARNm de otros genes proinflamatorios. En los mamíferos se han identificado varios grupos de estas proteínas, que incluyen ERK, JNK, las isoformas de p38 y ERK5 (51). Los complejos GR·GC inhiben las rutas de transmisión de señales de las MAPK, bloqueando la transducción de la repuesta desde los receptores de citoquinas proinflamatorias hasta el aparato transcripcional (Figura 11). Algunos subgrupos de MAPK, como JNK, regulan la activación del complejo AP-1 (52), y el subgrupo MAPK p38 regula la estabilidad de los ARNm que codifican moléculas proinflamatorias, como TNF- $\alpha$, IL-6, IL-8, factor de crecimiento del endotelio vascular (VEFG) o ciclooxigenasa-2 (COX-2) (53). La regulación negativa de las MAPK por parte de los GC tiene, por tanto, un efecto antiinflamatorio. En general, el GR inhibe la familia MAPK por la inhibición de la fosforilación necesaria para su activación, mediante la activación de la enzima MAPK fosfatasa-1 (MKP-1), mediante la expresión de Anexina-1 que regula la expresión de MKP-1 (54), y mediante la inducción de la síntesis de GILZ (Glucocorticoid-induce leucine zipper) que interacciona directamente con componentes de la cascada MAPK $(55,56)$. 


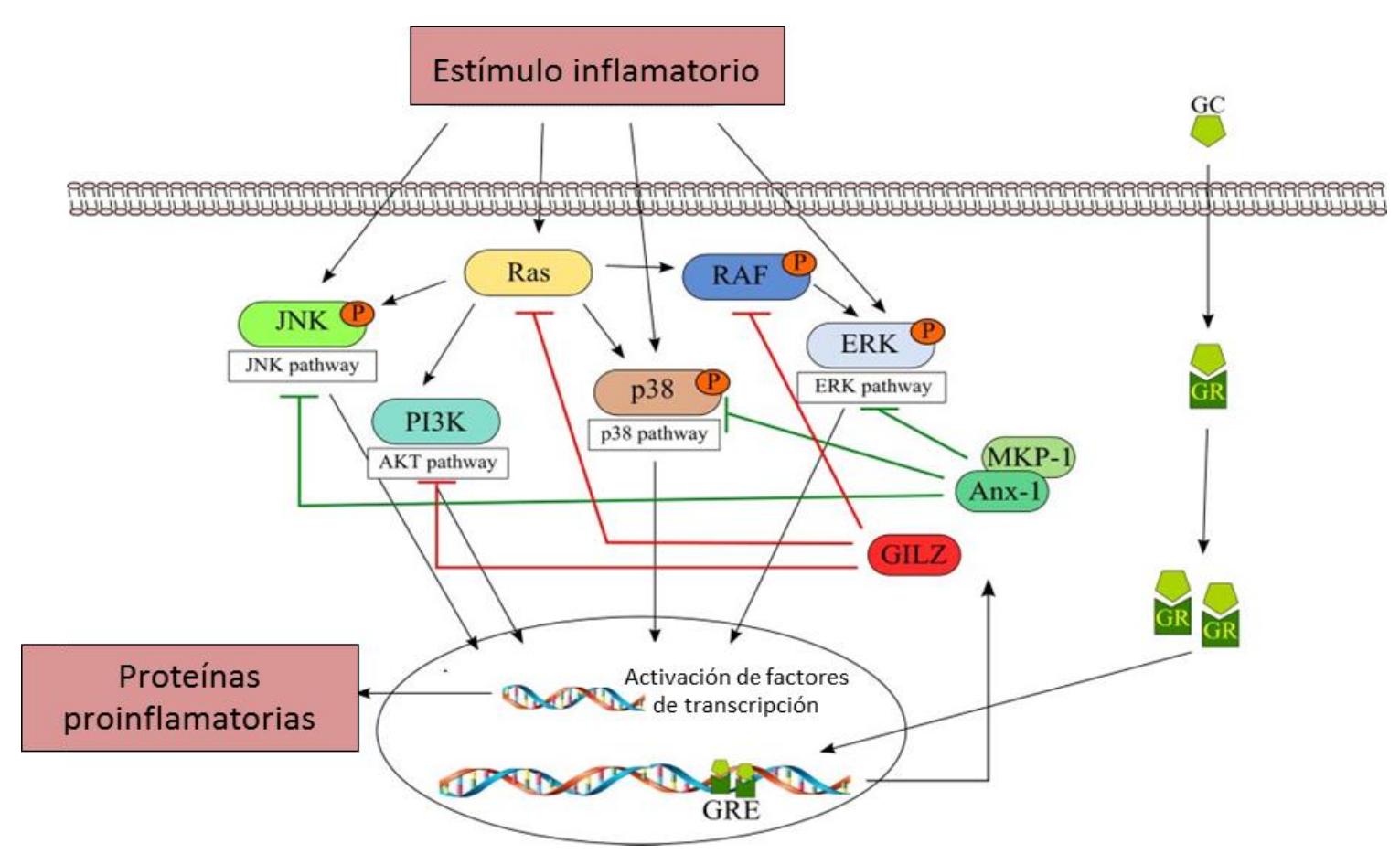

Figura 11: Interacción entre la activación de GR y la inhibición de MAPK. Modificado de (56).

\section{- Otros genes proinflamatorios}

El tratamiento con glucocorticoides puede inhibir otros genes implicados en la enfermedad pulmonar mediante una represión directa a través de la unión a GRE específicos en sus promotores. Así, la adición de dexametasona a cultivos de células pulmonares inhibe la expresión de MUC5AC (principal responsable de la producción de mucinas) mediante unión a dos GRE en su promotor (57).

\subsubsection{Genes inhibidores de la respuesta inflamatoria.}

Muchos de los genes que son activados por glucocorticoides tienen efectos antiinflamatorios, incluidos la anexina-1 (annexin-1, lipocortin-1), SLPI (Secretory leukocyte protease inhibitor), IL-10 e IKB- $\alpha$. A pesar de esto, las dosis terapéuticas de corticoides inhalados no muestran un incremento en la concentración de anexina-1 en 
el lavado broncoalveolar, ni tampoco se ha observado un incremento de IKB- $\alpha$ en muchos tipos celulares, incluidas las células epiteliales. Los GC también activan la síntesis de dos proteínas que afectan a las rutas de transducción de señales proinflamatorias, GILZ, que inhibe tanto NF-KB como AP-1, y MKP-1 que inhibe p38 MAPK (58).

Burnsides y cols. proponen usar sangre periférica total y PCR en tiempo real como método de detección (screening) de la capacidad de respuesta de un individuo al tratamiento con glucocorticoides en distintas enfermedades inflamatorias. Por un lado, comparan la variación de expresión de GILZ, FKBP51, FLAP y MKP-1 entre dos muestras, una no tratada y otra tratada con dexametasona $100 \mathrm{nM}$ (son genes estimulados por dexametasona); y, por otro lado, comparan la variación de la expresión de IL-6, TNF $\alpha$ e IFN $\gamma$ entre una muestra tratada con LPS y otra tratada con LPS + dexametasona (son genes reprimidos por dexametasona). Observan una elevada variación interpersonal entre la inducción o la represión máxima de estos genes. En cambio, encuentran que la variación es menor en aquellas concentraciones de máxima eficacia, tanto estimulantes como inhibitorias, sugiriendo que la eficacia relativa de la dexametasona es similar entre individuos, pero que la extensión o el rango de la respuesta varían. También observan que, mientras que el efecto sobre los genes inducibles se incrementa durante el curso del día, la represión de las citoquinas inducidas por LPS prácticamente no cambia durante el día (59).

El gen PTEN (phosphatase and tensin homologue) ha sido identificado como uno de los genes supresores de tumores más mutados en humanos. Funciona como una fosfatasa de la membrana plasmática que antagoniza la vía de transmisión de 
señales PI3K (phosphoinositide 3 kinase)-AKT. PTEN tiene multitud de efectos en el crecimiento celular, la migración, muerte celular y diferenciación. Se ha comprobado, en modelos animales y en cultivos de células pulmonares humanas A549, que la administración de dexametasona estimula la expresión de PTEN, que se encuentra disminuida en los pacientes asmáticos. PTEN ayuda a reducir la inflamación crónica regulando la expresión de $I L-17$, inhibiendo la óxido nítrico sintasa del endotelio e inhibiendo la migración de las células de músculo liso respiratorio. Por este motivo, algunos autores aseguran que la regulación específica de la expresión de PTEN en humanos puede usarse en los tratamientos del asma (60).

En un estudio realizado por Ben y col., se observó que se producía un incremento de ciertas acuoporinas (AQP3 y AQP5) en células pulmonares humanas (A549) en respuesta a un tratamiento con corticoides. Esto sugiere que AQP3 y AQP5 son la principal ruta del transporte de fluido alveolar en el epitelio respiratorio humano y en la hidratación de las vías respiratorias. La dexametasona y el ambrosol (mucolítico) estimulan la expresión de estas dos acuoporinas a nivel de ARNm y proteína, estando involucradas en la regulación del volumen y la composición del moco mediante mecanismos de transporte de agua (61).

\subsubsection{Genes relacionados con la estabilidad del ARNm}

Muchas proteínas inflamatorias están reguladas post-transcripcionalmente a nivel de la estabilidad del ARNm. Este parece ser un mecanismo de los GC para reducir la producción de proteínas inflamatorias después de que hayan sido activadas (62). La estabilidad de algunos genes inflamatorios viene determinada por la regulación de elementos ricos en $A U$ ( $A U$-rich elementes, $A R E)$, localizados en regiones $3^{\prime}$ no 
traducidas, que interactúan con HuR y tristetraprolina, que pueden estabilizar o desestabilizar, respectivamente, al ARNm. Genes como los que codifican GM-CSF y COX-2, producen un ARNm que es particularmente susceptible a la acción de ribonucleasas que rompen el ARNm. Los corticoides pueden inhibir los efectos de proteínas que estabilizan el ARNm, haciendo más rápida su desintegración, y esto reduce la expresión de las proteínas inflamatorias (63). Así, se ha demostrado que la dexametasona induce la síntesis de tristretraprolina (TTP) en células pulmonares A549 y en tejidos de ratas que se traduce en la disminución de los niveles de TNF- $\alpha$ (64).

\subsubsection{Genes relacionados con la remodelación de la cromatina}

La respuesta a glucocorticoides es diferente según el tejido y el tipo celular, lo que se debe a que la selección de los sitios específicos de unión en el ADN varía de unas células a otras. La accesibilidad de la cromatina, que es independiente de las hormonas, es clave en la unión del GR y define esta especificidad celular de la acción hormonal (65).

Cuando el GR se une al ADN, se reclutan moléculas coactivadoras como Brg1 (ATPasa remodeladora de la cromatina), la histona acetiltransferasa (HAT), CBP/p300 [(CREB)-binding protein/P300] y p/CAF, que desacetilan residuos de lisina del núcleo de las histonas y alteran la estructura de la cromatina hacia un estado accesible para la maquinaria transcripcional. Otros complejos coactivadores, como p/CIF, SW1/SNF y GRIP1/TIF2/NcoA-1 también contribuyen a la remodelación de la cromatina y al reclutamiento de la maquinaria de transcripción, incluyendo TBP y la RNA polimerasa II $(33,62,66)$. Debido a que las acciones de los GR están asociadas a su interacción con 
numerosas proteínas accesorias, la alteración en los factores accesorios puede modificar la sensibilidad y resistencia a los glucocorticoides.

\subsubsection{Genes relacionados con la activación de apoptosis}

La muerte celular programada inducida por el tratamiento con corticoides es selectiva. Mientras que en algunos tipos celulares como eosinófilos, basófilos o linfocitos T induce apoptosis, en otros, como neutrófilos y otras células de origen no linfoide, reprime las señales pro-apoptóticas (Figura 12).

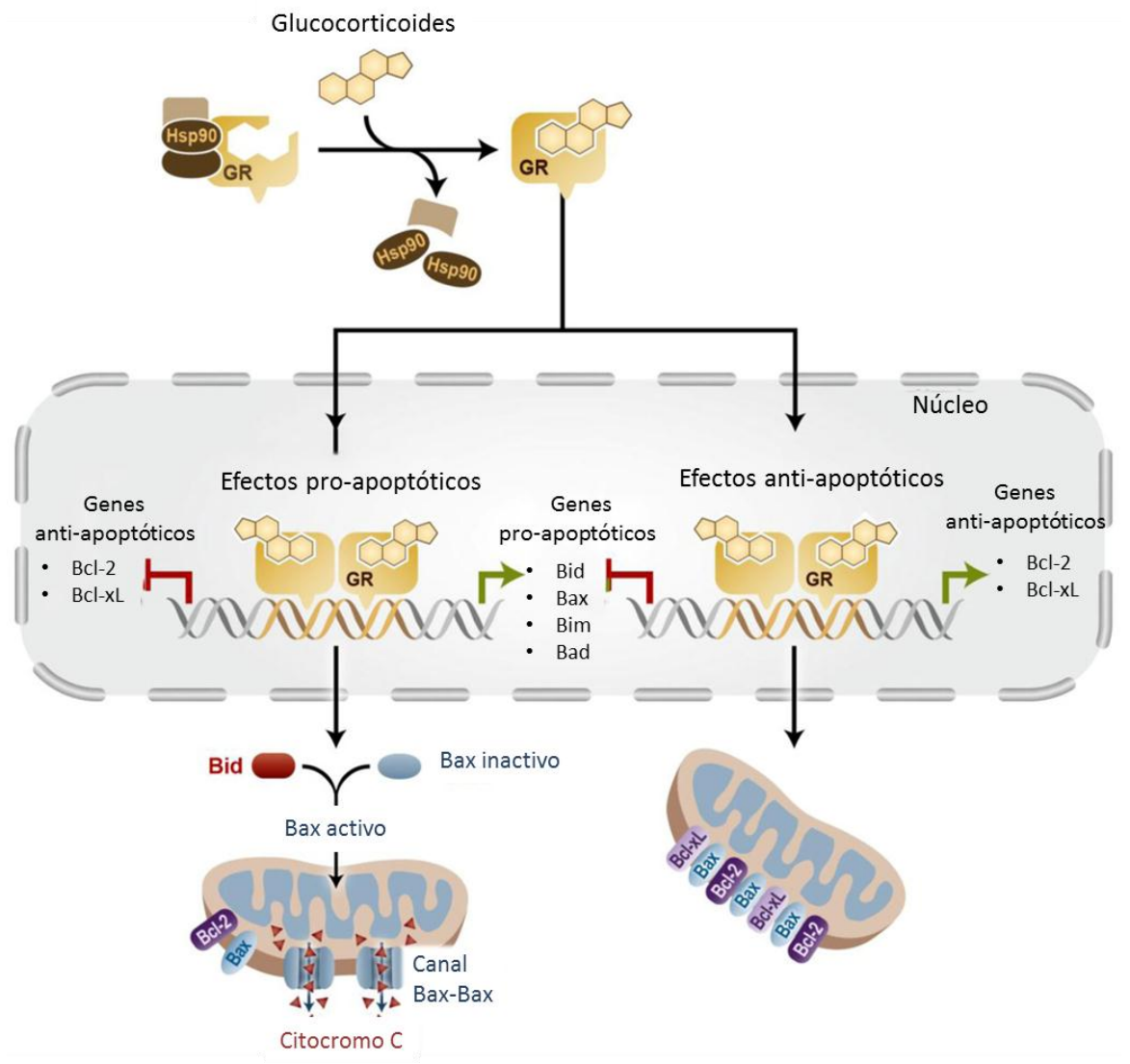

Figura 12: Papel del GR en la regulación del proceso apoptótico. Modificado de (67).

El mecanismo de apoptosis mediada por GC es muy complejo (las cascadas de transmisión de señales no están completamente identificadas), y envuelve 
mecanismos dependientes e independientes (transrepresión) del ADN. En la mayoría de los tipos celulares, los GC actúan modificando el equilibrio entre proteínas proapoptóticas como Bim, Bid, y Bad, y proteínas anti-apoptóticas como Bcl-2 y Bcl-xL (68). El patrón de fosforilación de los receptores de glucocorticoides en cada tipo celular establece el equilibrio de proteínas como Mcl-1 y NOXA (69). Además, los GC reprimen factores de transcripción y citoquinas necesarias para la supervivencia celular mediante la represión de NF-KB y AP-1.

Por otro lado, el nivel endógeno de GR dentro de la célula puede estar regulando la apoptosis mediada por GC. En este sentido, se requeriría un determinado nivel umbral del receptor de glucocorticoides para inducir los procesos apoptóticos. Este nivel de GR es alcanzado en células como los linfocitos $T$, donde existe un incremento aparente de los niveles de GR, a diferencia de la mayoría de las células, donde los niveles de GR están negativamente regulados en respuesta a los glucocorticoides (33).

\subsection{Mecanismos de acción no genómicos}

Los efectos genómicos de los GR no explican los efectos rápidos, a corto plazo, del tratamiento corticoideo. Existen mecanismos de acción no genómicos que tienen la característica de producirse en segundos o minutos, y de durar entre 60-90 minutos. Los GR modulan las rutas de transducción de señales mediante la interacción física y funcional con complejos del receptor de las células T, "T-cell receptor" (TCR), y por interferencia con señales de la vía JNK (70). Además, pueden incorporarse a las membranas celulares y modificar así sus propiedades fisicoquímicas, que pueden 
traducirse, por ejemplo, en la inhibición de la exocitosis mediada por IgE en mastocitos de sus mediadores inflamatorios (71). Se han descrito también receptores de glucocorticoides de membrana (mGR) que estarían involucrados en mecanismos proapoptóticos precoces e inmunomoduladores en células linfoides, y que podrían ejercer un papel de sensibilización o inducción de las actividades ya descritas de los receptores citosólicos (72).

\subsection{Asma: etiopatogenia}

Las enfermedades alérgicas respiratorias constituyen un grupo de patologías crónicas formado por la rinitis alérgica, el asma alérgica y la aspergilosis broncopulmonar alérgica (73), que están experimentando un incremento en su tasa de prevalencia en los últimos años, considerándose por ello una línea prioritaria en la investigación biomédica. Se estima que más de 300 millones de personas en todo el mundo padecen asma (74), con una prevalecía en España del 10\%, similar a la de la Unión Europea (75).

El asma es una enfermedad multifactorial, de etiología compleja, resultado de la interacción entre más de un centenar de genes, y entre éstos y el medio ambiente (76). La Guía Española para el Manejo del Asma (GEMA) define el asma como una "enfermedad inflamatoria crónica de las vías respiratorias, en cuya patogenia intervienen diversas células y mediadores de la inflamación, condicionada en parte por factores genéticos y que cursa con una hiperrespuesta bronquial y una obstrucción variable del flujo aéreo, total o parcialmente reversible, ya sea por la acción medicamentosa o espontáneamente". Se caracteriza por una infiltración de las vías 
aéreas por células inflamatorias, por el daño en el epitelio respiratorio, por el engrosamiento de la membrana basal, y por una hipertrofia del músculo liso bronquial (77). Los principales síntomas que cursan con la enfermedad son tos, disnea, sibilancias y opresión torácica (75).

La reacción inflamatoria subyacente en el asma y los efectos finales provocados en el paciente, vienen determinados por la interacción de varios tipos de células inflamatorias y una plétora de moléculas mediadoras de la inflamación, con múltiples efectos que actúan sinérgica o antagónicamente entre sí (78).

\subsubsection{Células inflamatorias}

\section{- Mastocitos}

Presentan receptores de alta afinidad para IgE (FcعRI) en su superficie, y su activación provoca la liberación de mediadores inflamatorios como prostaglandina $D_{2}$, leucotrienos e histamina, provocando broncoconstricción, secreción de moco y edema. También sintetizan y secretan citocinas proinflamatorias como IL-4, IL-5 e IL-13, que regulan la síntesis de IgE y estimulan la inflamación eosinofílica, y toda una serie de proteasas (triptasa y quimasa entre otras) implicadas en la inflamación de la vía respiratoria (79).

\section{- Eosinófilos}

La infiltración eosinofílica en las vías respiratorias es una de las características del asma. Los eosinófilos liberan mediadores inflamatorios capaces de provocar lesiones en la mucosa respiratoria y de estimular la hiperplasia del músculo liso 
respiratorio y la hiperreactividad bronquial (Figura 13). Además, se les atribuyen funciones de regulación de la respuesta inmune interviniendo en el equilibrio entre las poblaciones linfocitarias Th1 y Th2 (80).

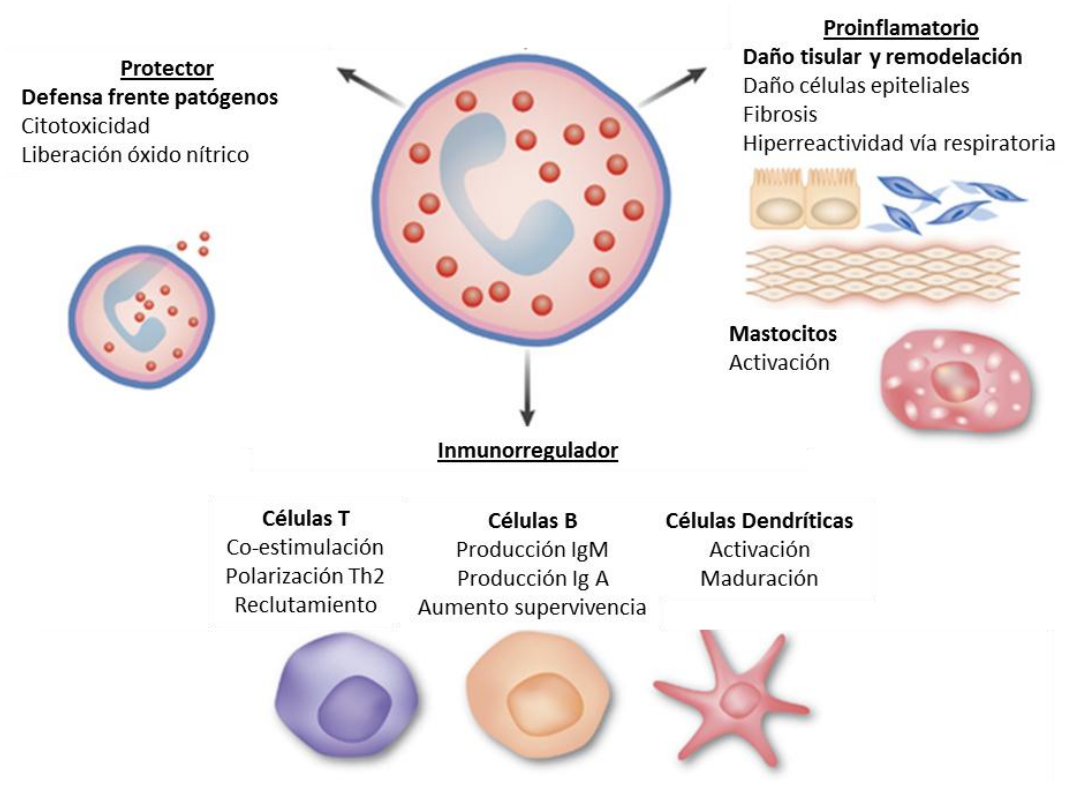

Figura 13: Papel del eosinófilo en la respuesta inmunitaria. Adaptado de (81).

\section{- Linfocitos T}

Los linfocitos T participan en la coordinación de la respuesta inflamatoria en el asma, fundamentalmente a través de la liberación de citocinas Th2 como IL-4, IL-5, IL-9 e IL-13, entre otras. Estas citocinas son responsables del reclutamiento de eosinófilos y mastocitos en las vías respiratorias, y de la inducción de la producción de IgE por las células B activadas $(77,82)$ (Figura 14). 


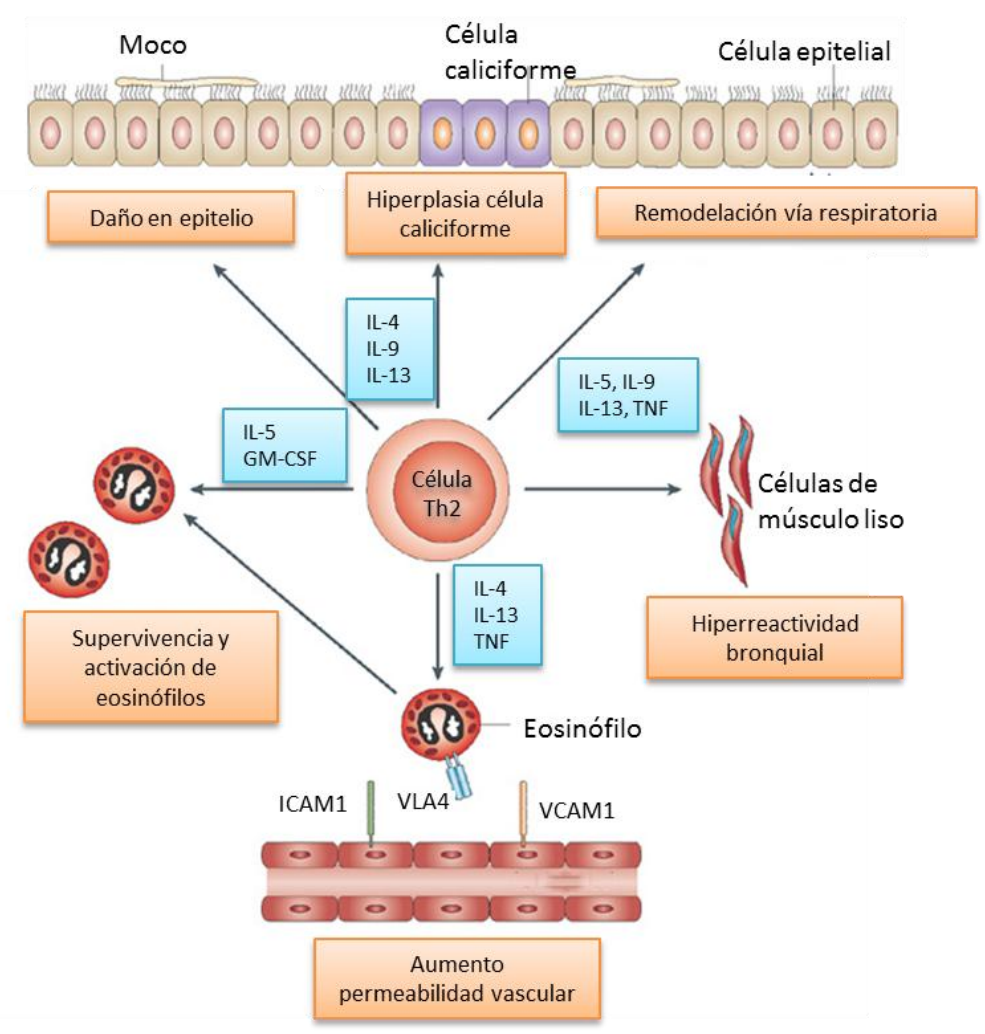

Figura 14: Papel del linfocito Th2 en la inflamación asmática. Modificado de (83).

\section{- Neutrófilos}

La presencia de neutrófilos en sangre periférica y lavado broncoalveolar de pacientes asmáticos se ha asociado a formas graves de la enfermedad y a resistencia al tratamiento corticoideo. Los neutrófilos provocan potentes acciones proinflamatorias a través de citocinas como IL-1, IL-9, TNF- $\alpha$ o GM-CSF, entre otras, que actúan sobre linfocitos T, eosinófilos, mastocitos y células del epitelio respiratorio $(77,84)$.

\section{- Células dendríticas}

Las células dendríticas desempeñan un papel central en el inicio y mantenimiento de la respuesta alérgica a través de sus funciones como células 
presentadoras de antígenos y mediante la activación de linfocitos T. Son capaces de potenciar una polarización Th2 mediante la inhibición de la producción de IL-12.

\section{- Células epiteliales}

Las células estructurales de las vías respiratorias desempeñan un papel fundamental en la patogenia no sólo como diana, sino también como parte activa en el proceso inflamatorio y de reparación de la vía respiratoria (Figura 15). Los alérgenos interaccionan directamente sobre la barrera epitelial y desencadenan la liberación de mediadores inflamatorios como moléculas de adhesión, interleucinas o quimiocinas, que provocan el reclutamiento de otras células inflamatorias que desencadenan la respuesta alérgica (85).

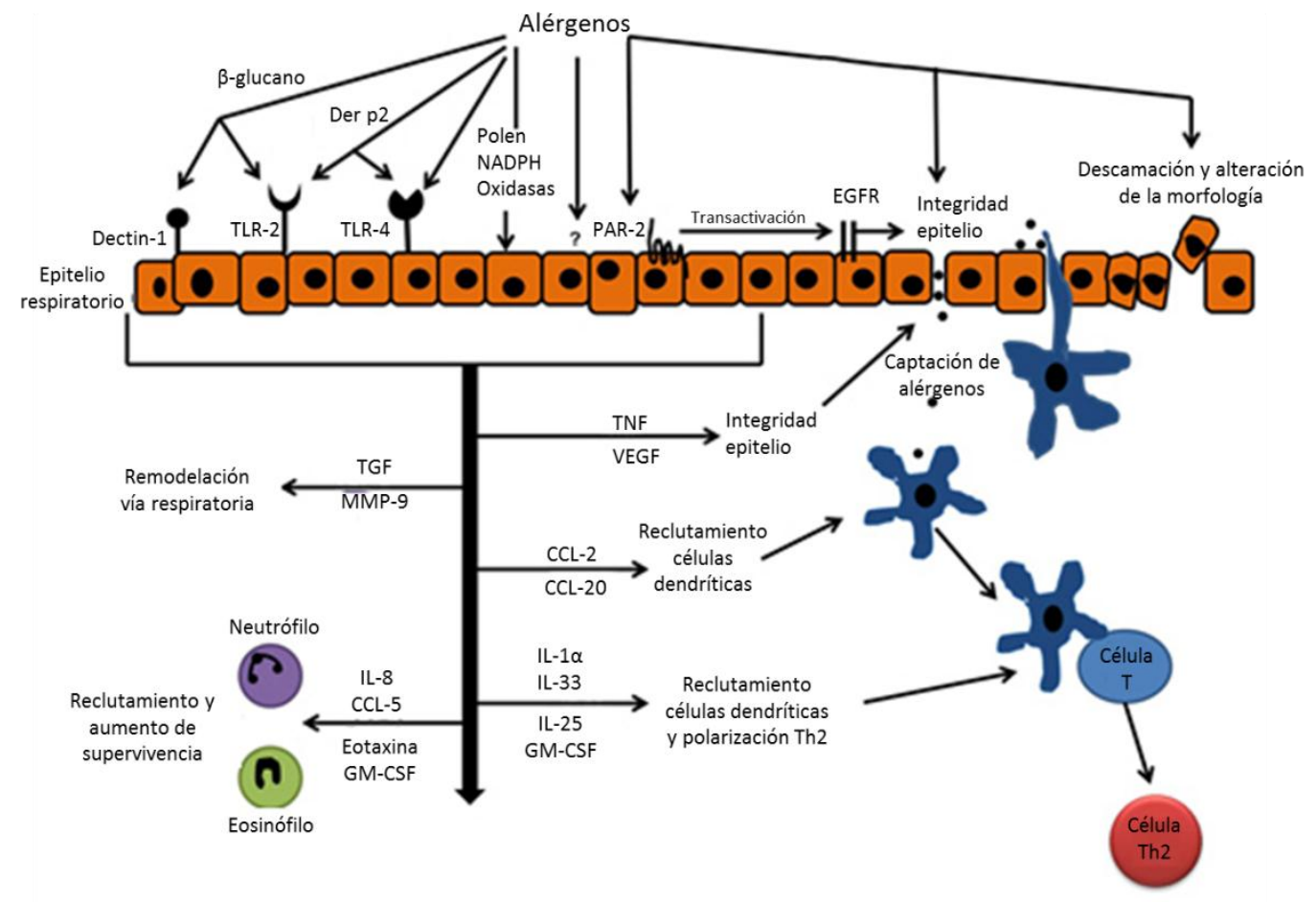

Figura 15: Implicación de las células epiteliales en el desarrollo del asma. Modificado de (85). 


\section{- Macrófagos alveolares}

Los macrófagos alveolares son las células más abundantes en el espacio alveolar y las vías respiratorias y están involucrados en el mantenimiento de la homeostasis inmunológica del tracto respiratorio. Estas células, una vez sensibilizadas, promueven la inflamación eosinofílica y las exacerbaciones asmáticas a través de la estimulación de la secreción de citocinas por los linfocitos $T$, y secretan mediadores proinflamatorias como TNF- $\alpha$, MIP-1 $\alpha$, eotaxina y óxido nítrico $(86,87)$.

\subsubsection{Mediadores inflamatorios}

\section{- Citocinas}

Son los mediadores principales de la respuesta inflamatoria en el asma. Se trata de un grupo de proteínas de masa molecular baja, que intervienen en la interacción y comunicación intercelular, con acciones autocrinas (sobre las mismas células que las secretan), paracrinas (sobre células contiguas) e incluso endocrinas (a distancia del sitio de síntesis) (88). Numerosos estudios han puesto de manifiesto la relación existente entre el asma y los genes codificantes de las citocinas, estableciendo asociaciones entre polimorfismos en estos genes y la susceptibilidad de padecer la enfermedad $(89,90)$. En la tabla 2 se muestran algunas citocinas implicadas en la patología asmática y sus efectos. 
Tabla 2: Relación de algunas de las citocinas implicadas en la patología asmática y sus efectos Modificado de (91).

\begin{tabular}{|c|c|c|c|}
\hline Citocina & Efectos & Citocina & Efectos \\
\hline IL-1 & $\begin{array}{l}\text { - Aumento de la adhesión } \\
\text { vascular } \\
\text { - Reclutamiento de neutrófilos } \\
\text { - Hiperreactividad bronquial }\end{array}$ & IL-13 & $\begin{array}{l}\text { - Activación eosinófilos } \\
\text { - Inhibición de la apoptosis } \\
\text { - Producción IgE }\end{array}$ \\
\hline IL-2 & $\begin{array}{l}\text { - Eosinofilia } \\
\text { - Estimulación células T }\end{array}$ & TNF- $\alpha$ & $\begin{array}{l}\text { - Activación del epitelio y de células } \\
\text { presentadoras de antígeno } \\
\text { - Hiperreactividad bronquial }\end{array}$ \\
\hline IL-4 & $\begin{array}{l}\text { - Eosinofilia } \\
\text { - Estimulación células Th2 } \\
\text { - Inhibición células Th1 } \\
\text { - Producción IgE }\end{array}$ & GM-CSF & $\begin{array}{l}\text { - Inducción de liberación de } \\
\text { leucotrienos } \\
\text { - Proliferación y liberación de células } \\
\text { hematopoyéticas } \\
\text { - Proliferación de eosinófilos }\end{array}$ \\
\hline IL-5 & $\begin{array}{l}\text { - Maduración eosinófilos } \\
\text { - Inhibición de la apoptosis } \\
\text { - Estimulación células Th2 } \\
\text { - Hiperreactividad bronquial }\end{array}$ & TGF- $\beta$ & $\begin{array}{l}\text { - Proliferación de fibroblastos } \\
\text { - Reclutamiento de monocitos, } \\
\text { fibroblastos y mastocitos } \\
\text { - Disminución de la proliferación de } \\
\text { células T }\end{array}$ \\
\hline IL-6 & $\begin{array}{l}\text { - Factor de crecimiento de } \\
\text { células Ty B } \\
\text { - Producción IgE }\end{array}$ & INF- $\gamma$ & $\begin{array}{l}\text { - Inhibición de células Th2 } \\
\text { - Disminución de síntesis de IgE } \\
\text { - Activación de macrófagos alveolares }\end{array}$ \\
\hline IL-10 & \multicolumn{3}{|c|}{$\begin{array}{l}\text { - Disminución de la supervivencia de eosinófilos } \\
\text { - Disminución de la activación de macrófagos } \\
\text { - Inhibición de células Th1 y Th2 }\end{array}$} \\
\hline
\end{tabular}

\section{- Quimiocinas}

Se trata de potentes quimioatrayentes de leucocitos que controlan su migración y su activación. También cumplen funciones de activación celular y promueven la liberación de histamina de los mastocitos (92). Entre las quimiocinas 
más importantes en el desarrollo del asma destacan CCL3 (MIP-1 $\alpha$ ), CCL4 (MIP-1 $\beta$ ), CCL5 (RANTES), CXCL10 (IP-10) y CCL11 (eotaxina).

\section{- Leucotrienos (LT)}

Son compuestos derivados del ácido araquidónico que actúan como potentes broncoconstrictores. Además, provocan vasodilatación actuando sobre los vasos sanguíneos, y aumentan la permeabilidad vascular y la inflamación eosinofílica. Son sintetizados, entre otros, por mastocitos y eosinófilos (93).

\section{- Histamina}

La histamina es un mediador inflamatorio liberado por mastocitos y basófilos que provoca broncoconstricción, vasodilatación y aumento de la permeabilidad $\operatorname{vascular}(94)$.

\section{- Óxido nítrico (NO)}

El óxido nítrico se sintetiza en células endoteliales y epiteliales de las vías respiratorias, y en células inflamatorias como mastocitos o macrófagos, y actúa como potente vasodilatador provocando extravasación plasmática y aumento de la secreción de moco (95).

\subsection{Utilización de los corticoides en el asma}

Desde su descubrimiento, la terapia con corticoides es utilizada frecuentemente en enfermedades cutáneas, oculares, del tracto digestivo, en la insuficiencia suprarrenal, en enfermedades autoinmunes y del tejido conectivo o en 
procesos cancerosos (96-99). Además, desde 1950, cuando se utilizó por primera vez la cortisona en aerosol en el tratamiento del asma bronquial (100), los corticoides constituyen la base del tratamiento en las enfermedades alérgicas y en el asma (101103).

Según la última versión de "Guía Española para el Manejo del Asma" (GEMA), el objetivo a cumplir cuando se instaura un tratamiento para el asma es "lograr y mantener el control de la enfermedad lo antes posible, además de prevenir las exacerbaciones y la obstrucción crónica del flujo aéreo y reducir al máximo su mortalidad". Para el control de la enfermedad se utiliza un tratamiento agrupado en escalones terapéuticos, dependiendo de la respuesta y evolución del paciente, y los fármacos de mantenimiento incluyen los glucocorticoides inhalados ( $\mathrm{GCl}$ ) o sistémicos (GCS), antagonistas de los receptores de leucotrienos (ARLT), agonistas $\beta_{2-}$ adrenérgicos, adrenérgicos de acción larga (LABA), tiotropio y biológicos, de los que sólo se dispone actualmente del omalizumab, un anticuerpo monoclonal anti-lgE (75).

Según esta guía, el uso de glucocorticoides está indicado, de forma inhalada, en cinco de los seis escalones terapéuticos, y como terapia alternativa, por vía sistémica, en el último escalón terapéutico (Figura 16). Los glucocorticoides inhalados (GCI) constituyen, por tanto, el pilar de la terapia en los pacientes con asma, y viene así recogido en todas las guías de tratamiento. Su uso reduce los síntomas, recupera la función pulmonar, reduce el grado de hiperreactividad bronquial y reduce el número de exacerbaciones (104). 


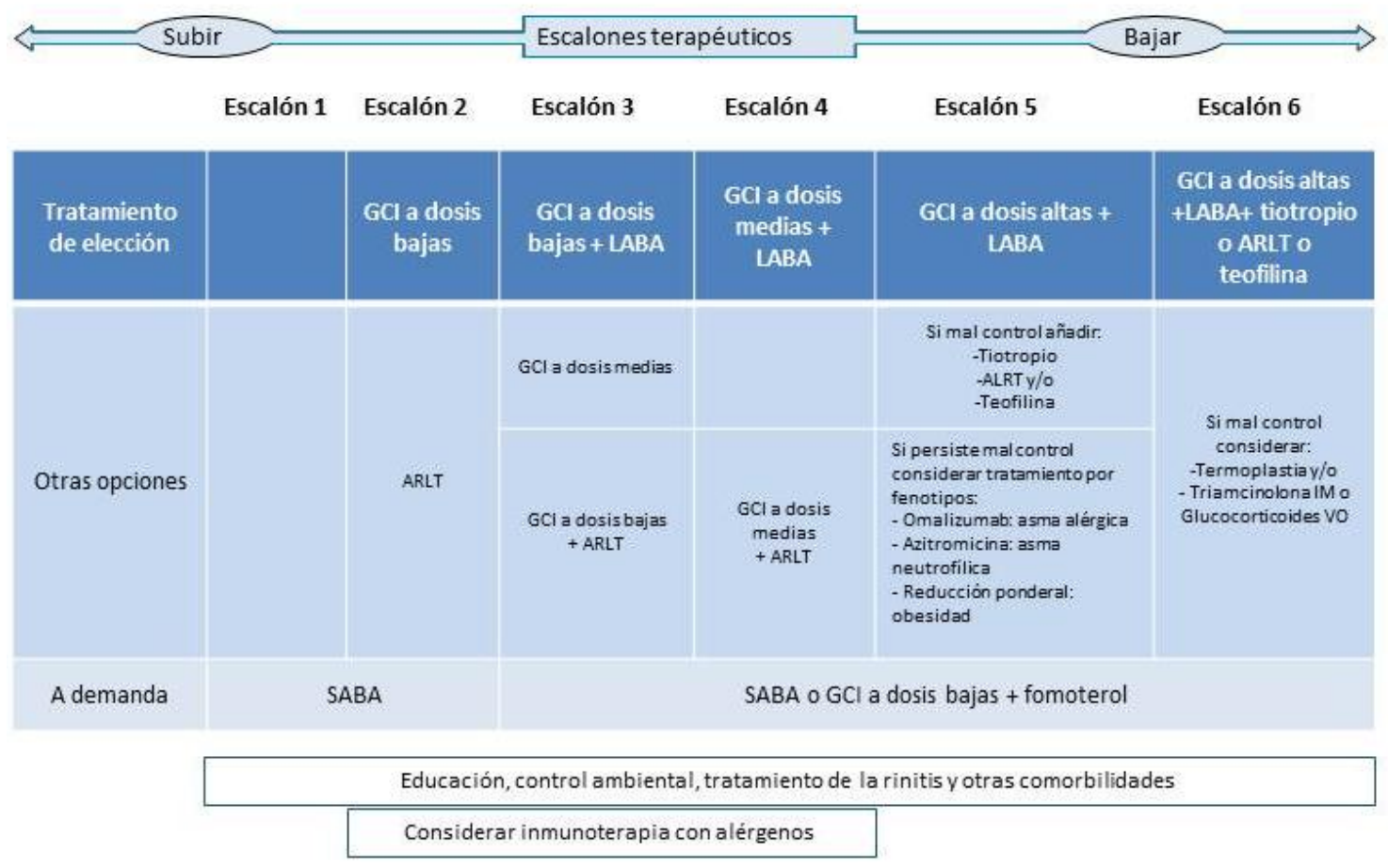

Figura 16: Escalones terapéuticos en el tratamiento del asma. Modificado de (75).

Aunque los $\mathrm{GCl}$ son los medicamentos más efectivos y más comúnmente utilizados en el tratamiento del asma, existe una elevada variabilidad en la respuesta entre individuos (105). Su utilización tiene la ventaja de administrar el fármaco directamente por el árbol bronquial, con una mejor distribución pulmonar, y ha mostrado más efectividad si se sigue un tratamiento diario durante largos periodos de tiempo, que si se hace de forma intermitente. Actualmente se inicia el tratamiento con dosis altas que permitan controlar de forma rápida la enfermedad, para luego ir disminuyendo la carga a la mínima dosis que permita el paciente (2), ya que siempre se debe utilizar la mínima dosis eficaz. En las dosis adecuadas, la utilización de $\mathrm{GCl}$ casi no tiene efectos secundarios aunque pueden producir disfonía, candidiasis, o tos y broncoespasmo, lo que puede reducirse utilizando cámaras de inhalación y enjuagándose la boca inmediatamente después de la administración (106). En 
pacientes asmáticos de edad avanzada, los periodos largos de tratamiento con $\mathrm{GCl}$ pueden aumentar los riesgos de insuficiencia adrenal, candidiasis oral o neumonía (107).

Entre los $\mathrm{GCl}$ disponibles en nuestro país se encuentran el dipropionato de beclometasona (DPB), budenosida (BD) y propionato de fluticasona (PF) siendo los dos últimos los que presentan una relación eficacia/seguridad más favorable. También se dispone de la ciclesonida, que pasa a su forma activa en las vías respiratorias (108). Es importante tener en cuenta los dispositivos de inhalación disponibles que puede ser de polvo, presurizados y nebulizadores. En función de cuál se utilice, se establecerá la dosis adecuada del fármaco, ya que influyen sobre el depósito pulmonar.

Los corticosteroides sistémicos se utilizan en pacientes con asma grave que no se controla con otras opciones terapéuticas, y como tratamiento en las agudizaciones que no responden a broncodilatadores $(109,110)$. La Sociedad Americana del Tórax (ATS, American Thoracic Society) y la Sociedad Europea de Respiratorio (ERS, European Respiratory Society) definen las exacerbaciones graves de asma como eventos que requieren medidas urgentes, y pueden usarse como marcadores de un pobre control de la enfermedad. En el documento de consenso "International ERS/ATS guidelines on definition, evaluation and treatment of severe asthma" publicado por ambas sociedades, se define el asma grave como aquella que "precisa tratamiento basado en las recomendaciones de la GINA escalón 4-5 en el año previo, o corticoides sistémicos durante $>50 \%$ del año anterior". La guía española GEMA define el asma grave no controlada (AGNC) como "la enfermedad asmática que persiste mal controlada pese a recibir tratamiento en el último año con una combinación de $\mathrm{GCl} / \mathrm{LABA}$ a dosis 
elevadas, o bien glucocorticoides orales durante al menos 6 meses". El consenso ATS/ERS (111) define el asma no controlada coma aquella que cumpla al menos uno de los criterios siguientes: (i) mal control sintomático, determinado mediante cuestionarios de control del asma; (ii) exacerbaciones graves frecuentes que han precisado 2 o más ciclos de glucocorticoides orales durante más de tres días; (iii) exacerbaciones graves con al menos una hospitalización en UVI o que precisó ventilación mecánica en el año previo; o (iv) por una limitación crónica del flujo aéreo, con un FEV1 inferior al 80\% (con un FEV1/FVC por debajo del límite inferior de la normalidad) a pesar de un tratamiento broncodilatador adecuado. Como se puede observar, uno de los puntos clave para definir el asma mal controlada es la presencia de exacerbaciones graves. Estas exacerbaciones graves pueden identificarse como aquellos casos en los que se requiere el uso de corticosteroides sistémicos o el aumento de la dosis normal de mantenimiento durante al menos tres días, o aquellos casos que requieren hospitalización, estancia en una Unidad de Cuidados Intensivos, o ventilación mecánica $(111,112)$.

El principal problema del uso de corticosteroides sistémicos es la cuantificación de la dosis y la duración del tratamiento, y que no existen protocolos claros establecidos y consensuados. Además, los corticosteroides sistémicos tienen más peligro de provocar efectos adversos como osteoporosis, fracturas, obesidad, diabetes..., y estarían indicados en aquellos casos en los que los beneficios para el paciente superan los posibles riesgos (113). Pese a esto las diferentes guías publicadas aconsejan el uso de corticoides sistémicos en el tratamiento de agudizaciones graves, y también para exacerbaciones moderadas o leves en las que no hay respuesta a $\beta$ antagonistas y se ha fracasado con otras opciones terapéuticas, además de aquellos 
casos en los que el paciente estaba ya tratado con glucocorticoides orales o presenta antecedentes de crisis asmáticas que necesitaron administración de corticoides sistémicos con anterioridad (75).

El régimen de tratamiento con corticosteroides sistémicos más extendido es el de prednisona o prednisolona por vía oral una o dos veces al día, generalmente durante cinco a diez días, que debe prescribirse lo antes posible, puesto que su efecto comienza a las 4-6 horas tras su administración. Existen publicaciones que indican que dos dosis únicas de dexametasona administradas de forma oral o intramuscular en pacientes que sufren exacerbaciones de asma grave puede ser una vía alternativa al tratamiento con prednisona/prednisolona durante 5 días, incluso en pacientes pediátricos (114). Esta disminución en el tiempo de tratamiento y de dosis necesaria se consigue por la mayor vida media de la dexametasona, aproximadamente el doble que la de la prednisona, y por su mayor efecto antiinflamatorio, que puede superar en cinco veces al de la prednisona (115). Sin embargo, la GEMA recomienda restringir su uso en las crisis graves o en las moderadas cuando no se obtiene mejoría con broncodilatadores, sobre todo en niños.

\subsection{Resistencia a los corticoides.}

Entre un $5 \%$ y un $10 \%$ de pacientes asmáticos no responde bien a la terapia con corticoides y agonistas beta-adrenérgicos (116), desarrollando un asma grave que requiere la administración de dosis elevadas de glucocorticoides con mínima mejoría de su enfermedad. La definición realizada por la GEMA de asma grave no controlada resistente a corticoides incluye aquellos casos que cursan con un FEV1 $\leq 75 \%$ en los 
que, tras el tratamiento con prednisona (40 mg/d durante dos semanas), no se produce una mejoría de al menos el $15 \%$ en el FEV1. Además, establece un tipo de asma grave corticodependiente que se caracteriza por la necesidad de administración continua de glucocorticoides sistémicos.

\subsubsection{Contexto genético del paciente}

Según algunos estudios de perfiles de expresión génica, existe una predisposición genética a la resistencia a glucocorticoides. Hakonarson et al., proponen una serie de 11 genes en células mononucleares de sangre periférica (PBMC) con los que, según sus patrones de expresión, se puede predecir la respuesta clínica a la terapia con GC inhalados con una sensibilidad superior al $80 \%$. Entre estos genes se encuentran el gen que codifica la subunidad de unión del ADN de NF-KB, STAT-4 y el gen IL-4-R (117). También se ha confirmado, mediante GWAS, la asociación de otros polimorfismos localizados en los genes PTGDR, PTGER2, MS4A2, PRPF19, AHNAK, FRMD6 (118), y BMPRIII (119) con el asma grave. Así mismo, polimorfismos localizados en el gen GLCCI1 (Glucocorticoid-induced transcript 1 gene) inducen decrementos substanciales en la respuesta a GC inhalados en pacientes con asma. Un polimorfismo encontrado en este gen, rs37973, puede reducir la apoptosis de linfocitos y eosinófilos mediada por GC, y, por tanto, provocar una menor respuesta clínica al tratamiento con GC inhalados (120).

En el gen del receptor de glucocorticoides también se han descrito varios polimorfismos y mutaciones somáticas responsables de la pérdida de afinidad a dexametasona y la consiguiente resistencia al tratamiento en pacientes con leucemia linfoblástica aguda (30). 


\subsubsection{Fenotipos en el asma}

Se diferencian varios tipos de asma grave (Tabla 3). Entre ellos se encuentra el asma "clásica" o eosinofílica, en la que existe un predominio de eosinófilos. Por otra parte, hay un segundo tipo caracterizado por un aumento de los leucocitos neutrófilos en el esputo y las biopsias bronquiales (121), probablemente derivado de una activación persistente de la inmunidad innata, y que es el que se asocia a una peor respuesta a los GC inhalados (122). Como se ha comentado anteriormente, a diferencia de lo que ocurre con eosinófilos, los GC son incapaces de inducir apoptosis en los neutrófilos, lo que dota a la inflamación neutrofílica de resistencia ante el tratamiento con estos compuestos (123). Algunos autores afirman que en algunos casos, de desarrollo del fenotipo de asma "neutrofílica" puede deberse al propio tratamiento esteroideo, que produce apoptosis de los eosinófilos y neutrofilia. Además, se piensa que esta respuesta neutrofílica puede estar mediada por células Th17, estimuladas por IGF- $\beta$ e IL-6 (124), y productoras de IL-17A, IL-17F, IL-21 e IL-22, que inducen inflamación de las vías respiratorias y estimulan la contractilidad del músculo estriado (125). Las citoquinas Th17, además, inducen proliferación de células musculares de las vías respiratorias mediante activación de la ruta ERK1/2 y de NF-KB (126). La IL-17 puede estar implicada también en la estimulación de la isoforma $\beta$ del receptor de GC, que ejercería una acción inhibitoria frente a la isoforma $\alpha$ (127). Sin embargo, otros autores rechazan el papel de la isoforma $\beta$ en la resistencia a glucocorticoides debido a que no se ha conseguido demostrar el aumento de la expresión de este GRß en PBMC de los pacientes asmáticos corticorresistentes (63). Ather y col. establecen una conexión entre la producción de un reactante de fase aguda en procesos inflamatorios, la proteína sérica amiloide $A$ (SAA), y una 
estimulación de la producción de citoquinas Th17 por células T CD4+, que las hace resistentes a la apoptosis mediada por glucocorticoides, impidiendo la resolución del estado inflamatorio (128).

Tabla 3: Características clínicas y biológicas de los fenotipos del asma grave del adulto. Modificado de (75).

\begin{tabular}{|c|c|c|}
\hline & Clínica función pulmonar & Biomarcadores patogenia \\
\hline Asma alérgica & Síntomas alérgicos & $\begin{array}{c}\text { IgE específica } \\
\text { Citoquinas Th2 } \\
\text { Periostina } \\
\text { Eosinófilos y neutrófilos esputo }\end{array}$ \\
\hline Asma eosinofílica & $\begin{array}{l}\text { Sinusitis } \\
\text { Menos alergia } \\
\text { EREA }\end{array}$ & $\begin{array}{c}\text { Corticorresistente } \\
\text { IL-5 } \\
\text { Cistenil-leucotrienos } \\
\text { Eosinófilos en sangre y esputo }\end{array}$ \\
\hline Asma y obesidad & $\begin{array}{l}\text { Más en mujeres } \\
\text { Muchas síntomas } \\
\text { Menos HRB }\end{array}$ & Estrés oxidativo \\
\hline Asma neutrofilica & $\begin{array}{c}\text { Menor FEV } \\
\text { Mayor atrapamiento }\end{array}$ & $\begin{array}{c}\text { Neutrófilos en esputo } \\
\text { Activación Th17 } \\
\text { IL-8 }\end{array}$ \\
\hline
\end{tabular}

EREA: enfermedad respiratoria exacerbada por el ácido acetilsalicílico. HRB: hiperreactividad bronquial

Por otro lado, la gravedad del asma puede estar relacionada con la presencia de distintos fenotipos de mastocitos. Se han descrito mastocitos triptasa positivos, y mastocitos triptasa y quimasa postivos. Estos últimos están asociados con el asma grave y su activación contribuye a incrementar los niveles de prostaglandina $D_{2}\left(P_{G} D_{2}\right)$. El asma grave se asocia con número más reducido de mastocitos totales, pero con una mayor proporción de mastocitos triptasa y quimasa positivos en la submucosa, mientras que en el asma no grave los más abundantes son los mastocitos solo positivos a triptasa (129). 


\subsubsection{Fallo en la afinidad de GR, en la translocación nuclear, y en su unión a GRE}

La actividad antiinflamatoria de los glucocorticoides está ligada al estado de fosforilación de su receptor. Existen varios residuos de Serina en el GR susceptibles de fosforilación, y los ciclos de fosforilación/desfosforilación regulan la translocación del receptor al núcleo celular y su actividad transcripcional. Así, mientras que la fosforilación en los sitios Ser203 y Ser211 por complejos Cdk2/Ciclina A cinasa se asocian con la activación del GR, la fosforilación por la cinasa c-Jun N-terminal (JNK) en Ser226 inhibe su actividad transcripcional y regula su exportación desde el núcleo celular al citoplasma. Se ha comprobado un aumento de los niveles de GR fosforilado en Ser226 en PBMC de pacientes con resistencia a corticoides, además de la disminución de los niveles de PP2A, una serina/treonina fosfatasa encargada de la desfosforilación del receptor de glucocorticoides en Ser226 (130).

Sher y col., describen dos patrones anormales de unión a ligando en los GR de pacientes asmáticos corticorresistentes, denominados tipo 1 y tipo 2 . El tipo 2 es muy poco común, afectaría a toda la población de células mononucleares, y está relacionado con una densidad reducida de GR pero que tienen una afinidad normal. El tipo 1 es el más común, está asociado con una afinidad de unión reducida del GR, siendo normal el número de receptores, y es específico de linfocitos T (131). En los linfocitos $T$ de estos pacientes existe una sobreexpresión de interleucinas proinflamatorias, como IL-2 e IL-4, que estimulan la activación de p38 MAPK y que se traduce en la fosforilación del GR y la reducción de su translocación al núcleo, y de su afinidad por los GRE (132). En los monocitos, la IL-13 mimetiza estos efectos. Las IL-2, IL-4 e IL-13 también se encuentran incrementadas en las biopsias bronquiales y en el 
lavado broncoalveolar de los pacientes con asma resistente a esteroides (133). Otros autores sostienen que la respuesta más pobre a los corticoides se debe, más que a la sobreexpresión de IL-2/IL-4, a la menor inhibición de la liberación de citoquinas por parte de células mononucleares de sangre periférica. Se han encontrado diferencias significativas en IL-1B, IL8, MIP-1a e IL6, y menos obvias para IL-10, MCP-1 y RANTES (134).

\subsubsection{Incapacidad para inhibir mecanismos proinflamatorios}

Los glucocorticoides inducen la expresión de MAPK fosfatasa-1 (MKP-1), inhibidor de genes MAPK, y, además, reducen su degradación. En los macrófagos alveolares de los pacientes asmáticos que no responden a glucocorticoides existe una menor inducción de MKP-1 que en los pacientes respondedores a glucocorticoides y, como consecuencia, la MAPK p38 está más activada (70). La fosforilación de GR mediada por p38MAPK, y también por GSK3, provoca que la represión de NF-KB mediada por GC esté atenuada (43). Además, en las células mononucleares de sangre periférica de pacientes con asma grave existen niveles incrementados de p65 (RelA), IKB fosforilado (inactivo), y de IKK $\beta$ (cinasa de IkB). Esto conlleva a un exceso de NF-KB activo, que combate la acción antiinflamatoria de los glucocorticoide (135).

Además de los cambios en la activación de NF-KB, en las células mononucleares de los pacientes resistentes a GC existe una inhibición defectuosa de AP-1 en respuesta a GC, debido a una sobreexpresión de AP-1 mediada por citoquinas Th2. La falta de supresión de la fosforilación de JNK, por falta de inhibición de la ruta MAPK conduce a la falta de supresión de la fosforilación de c-Jun y c-Fos, que desemboca en una intensidad de interacción GR·AP1 disminuida (70). 


\subsubsection{Otras causas de resistencia a glucocorticoides.}

Otra característica de los pacientes con asma grave es que presentan una actividad reducida de las enzimas HAT (histona acetiltransferasa) y HDAC (histona desacetilasa), lo que reduce y trastorna la acción de la dexametasona sobre la expresión de marcadores proinflamatorios (136). Además, los niveles de expresión de ciclina D1 están aumentados, no se reducen con la terapia con corticoides y provocan una hiperplasia del músculo esquelético de las vías respiratorias (137).

Por otro lado, se ha comprobado que las infecciones por rinovirus pueden inducir resistencia a corticoides en los pacientes asmáticos a través de la activación de IKK y JNK, y la consecuente potenciación de las vías de transmisión de señales mediadas por NF-KB (138), así como de la fosforilación del GR.

\subsection{El gen PTGDR y su importancia en las enfermedades alérgicas}

\subsubsection{Prostaglandina $D 2$}

Los mastocitos son células inmunológicas localizadas en mucosas y tejidos epiteliales, fundamentalmente en el tracto gastrointestinal, piel y epitelio respiratorio (139). En el comienzo de una reacción alérgica, la unión de complejos alérgeno-lgE a los receptores de membrana FceRI de los mastocitos origina dos procesos importantes (Figura 17). Por un lado, provoca la liberación mediadores preformados de la respuesta alérgica como la histamina, triptasa, heparina, factores quimiotácticos de eosinófilos, neutrófilos y monocitos y factor activador de plaquetas, entre otros $(140,141)$; y, por 
otro lado, se produce la generación y liberación de diversas citocinas, y de metabolitos del ácido araquidónico, entre ellos la prostaglandina $D_{2}\left(P D_{2}\right)(142)$.

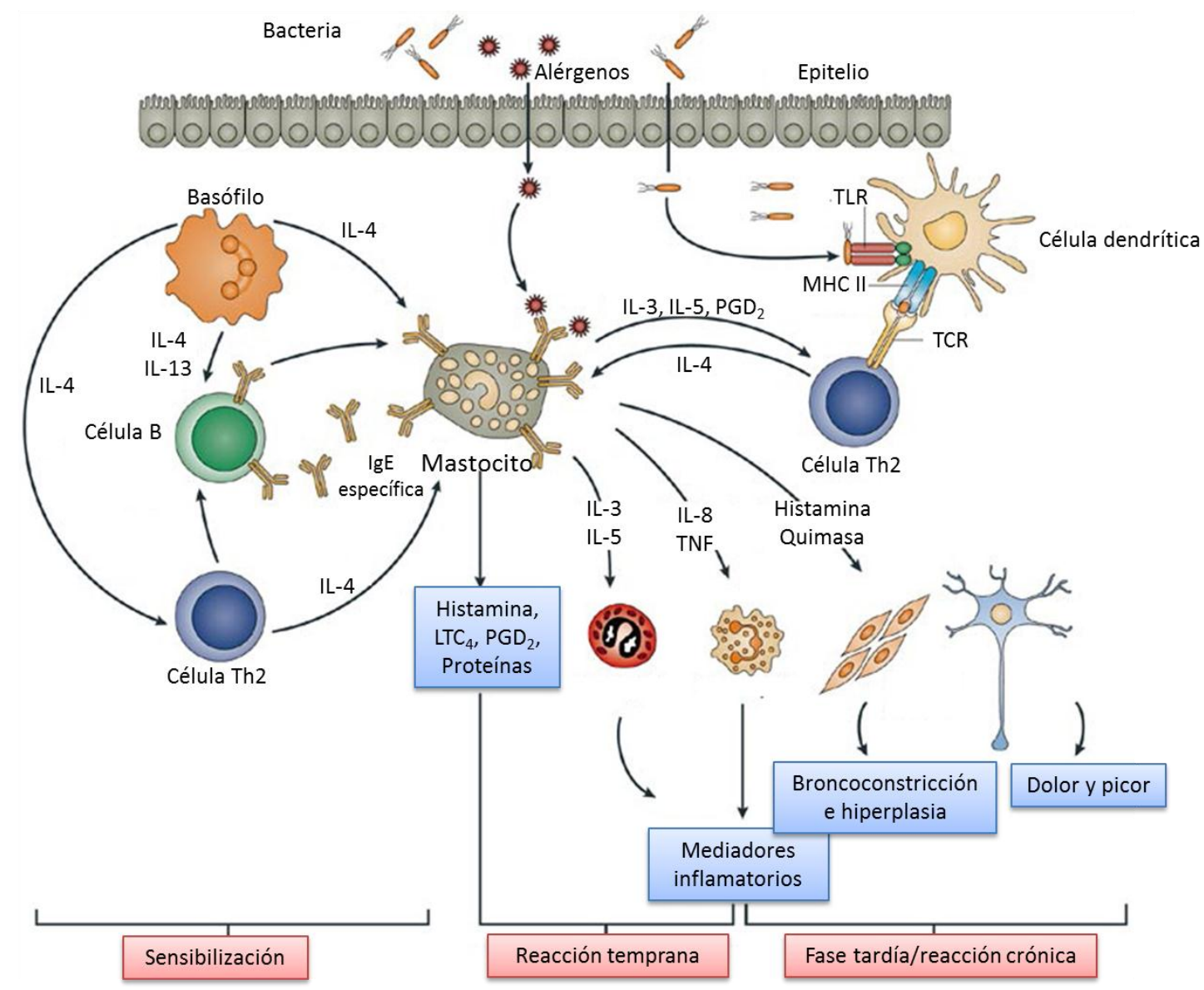

Figura 17: Activación de mastocito por complejo IgE-alérgeno. Modificado de (143).

La estimulación del mastocito provoca la activación de la fosfolipasa $A_{2}\left(P_{2} A_{2}\right)$, que libera ácido araquidónico $(\mathrm{AA})$ a partir de los fosfolípidos de membrana. Una vez en el citoplasma celular el AA da lugar a la síntesis de leucotrienos mediante su metabolización a través de lipooxigenasas, o a la síntesis de prostaglandinas y tromboxanos mediante su metabolización a través de ciclooxigenasas (COX). Todos estos metabolitos del AA son mediadores lipídicos con importantes acciones en los procesos inflamatorios y la respuesta inmunológica (144). 
Se han descrito dos isoformas de enzimas ciclooxigenasas. La isoforma COX-1 se expresa en la mayoría de tipos celulares de forma constitutiva, mientras que la isoforma COX-2 es una enzima inducible que actúa en la respuesta temprana de la reacción inmune (145). Ambas metabolizan el AA mediante su acción ciclooxigenasa dando lugar a la prostaglandina $G_{2}\left(P_{G} G_{2}\right)$, que rápidamente se transforma en prostaglandina $\mathrm{H}_{2}\left(\mathrm{PGH}_{2}\right)$ por la acción peroxidasa de las mismas enzimas. A partir de aquí, y por mediación de sintasas específicas, se producen toda una batería de prostaglandinas $\left(\mathrm{PGD}_{2}, \mathrm{PGE} \mathrm{E}_{2}, \mathrm{PG} \mathrm{F}_{2}\right)$, prostaciclinas $\left(\mathrm{PGI}_{2}\right)$ y tromboxanos $\left(\mathrm{TXA}_{2}, \mathrm{TXB}_{2}\right)$. En los mastocitos, el patrón de expresión de estas sintasas específicas hace que la prostaglandina $D_{2}\left(P G D_{2}\right)$ sea su metabolito más abundante (146). El mastocito, por tanto es el mayor productor de $\mathrm{PGD}_{2}$, aunque también es secretada por células dendríticas (147) y células Th2, fibroblastos (148), células musculares y células epiteliales.

La prostaglandina $D_{2}$ es una molécula de transmisión de señales biológicas que ejerce su acción en diferentes tipos celulares y tejidos, afectando a la regulación del flujo sanguíneo, al ciclo sueño-vigilia (149), a la capacidad de respuesta a la insulina (150), adrenalina y glucagón (151), al metabolismo óseo (152), al desarrollo sexual correcto en el feto (153), a procesos reproductivos (154), a la contracción muscular, o a la regulación de la respuesta inmune y los procesos inflamatorios (155).

Se han identificado dos sintasas de $\mathrm{PGD}_{2}$, la sintasa tipo lipocalina, o L-PGDS, y la sintasa hematopoyética, o H-PGDS (Figura 18). La enzima L-PGDS se expresa en sistema nervioso central, corazón y tejido adiposo, mientras que H-PGDS se expresa en 
tejidos periféricos y células inmunológicas, como mastocitos, macrófagos, células presentadoras de antígenos y algunos linfocitos de tipo Th2 (156).

Posteriormente, mediante reacciones no enzimáticas de deshidratación, la $\mathrm{PGD}_{2}$ se transforman en ciclopentanonas, como son 15 -Deoxy- $\Delta^{12,14}-\mathrm{PGD}_{2}, \Delta^{12}-\mathrm{PGD}_{2}$, $P \mathrm{PJ}_{2}, \Delta^{12}-\mathrm{PGJ}_{2}, 15-$ deoxy$-\Delta^{12,14}-\mathrm{PGJ},(15 \mathrm{~d}-\mathrm{PGJ})(155,157)$.

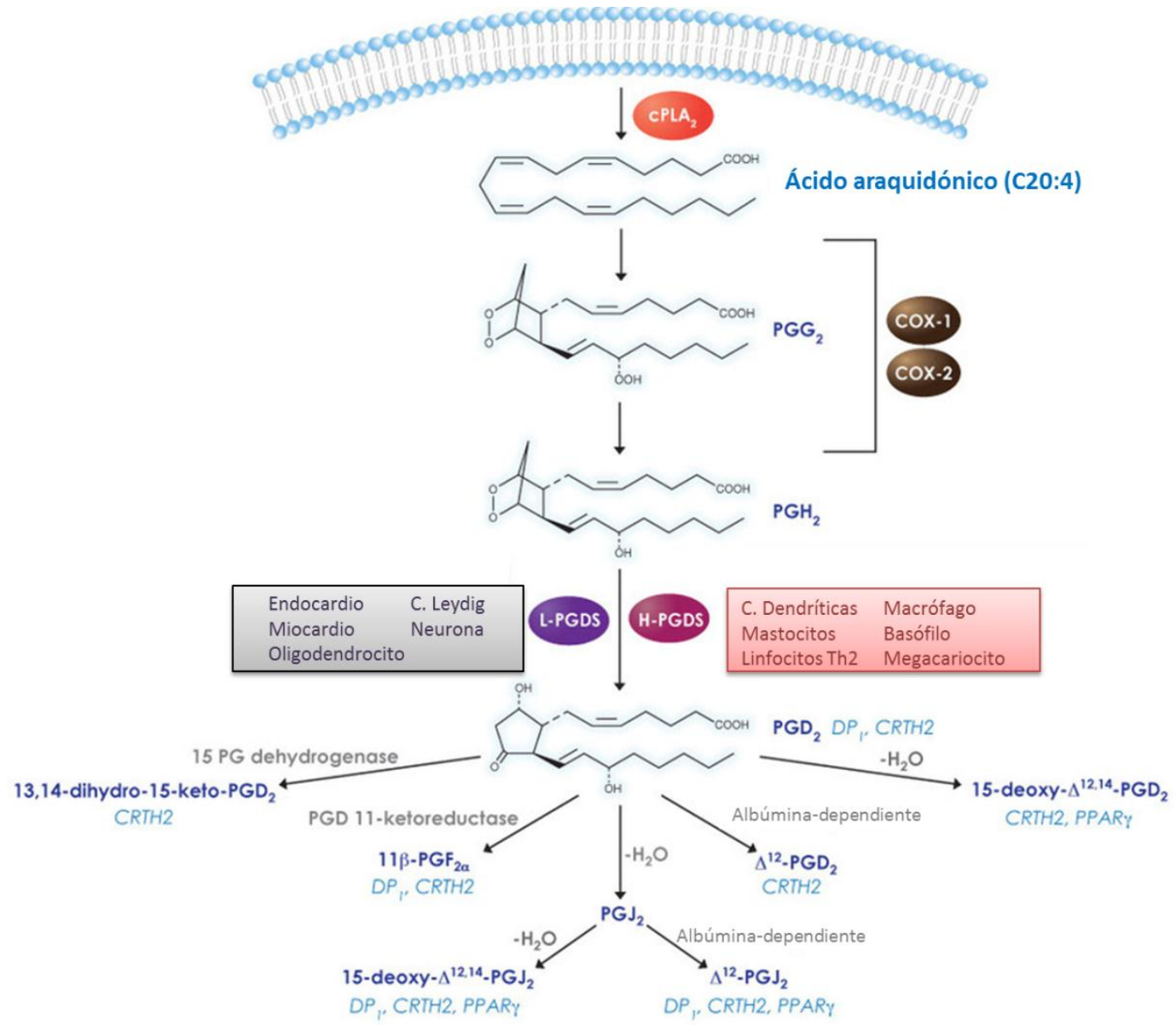

Figura 18: Biosíntesis de $\mathrm{PGD}_{2}$ y sus metabolitos. Modificado de (158). Debajo de cada metabolito se especifica el receptor al que se asocia.

\subsubsection{Receptores de la Prostaglandina D2 y su papel en el proceso inflamatorio}

La actuación de la $\mathrm{PGD}_{2}$ está mediada fundamentalmente por dos receptores transmembranarios específicos, PTGDR (también llamado DP o DP1) y CRTH2 (también 
llamado DP2), ambos pertenecientes a la superfamilia de receptores asociados a proteínas G heterotriméricas (159). El receptor PTGDR se expresa en células del sistema inmune, como linfocitos Th1 y Th2, linfocitos B, células dendríticas, eosinófilos, basófilos y neutrófilos, pero también se expresa en plaquetas, células del sistema nervioso central, en células ciliadas y no ciliadas de los bronquiolos, y en células epiteliales alveolares de tipo I y de tipo II (160). Ejerce su acción asociándose con la proteína Gs $\alpha$ e incrementa la concentración celular de adenosín monofosfato cíclico (AMPc). CRTH2 se acopla con la proteína Gia y produce incremento del $\mathrm{Ca}^{2+}$ y descenso del AMPc (Figura 19), y su expresión se limita a eosinofilos, basófilos y linfocitos Th2 $(161,162)$. A pesar de que ambos receptores coinciden en varios tipos celulares, PTGDR es menos abundante en los eosinófilos y basófilos que CRTH2 (163).

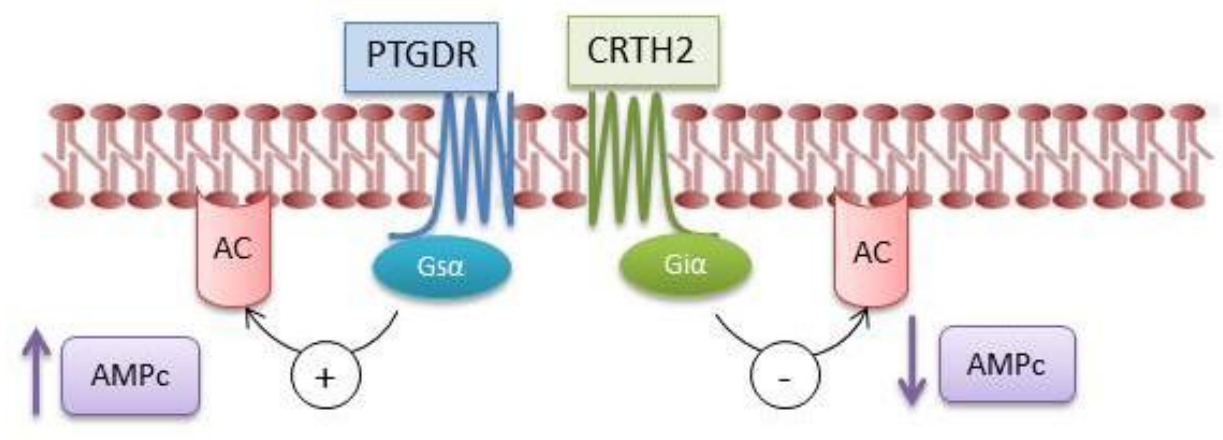

Figura 19: Mecanismo de acción de los dos receptores de prostaglandina $D_{2}$. AC: Adenilato ciclasa.

Aunque de forma clásica se ha considerado únicamente un papel inductor de la $\mathrm{PGD}_{2}$ en procesos inflamatorios, existen estudios que evidencian que también podría realizar una función moduladora e incluso inhibitoria de la cascada inmunológica. Algunos autores ponen de manifiesto que esta acción dual de la $\mathrm{PGD}_{2}$ puede darse 
dependiendo del receptor involucrado, aunque también existen estudios contradictorios en este aspecto (164).

Por un lado, se constata una acción vasodilatadora y broncoconstrictora potente de la $\mathrm{PGD}_{2}$ en pacientes asmáticos por acción directa sobre sus receptores en las vías respiratorias, y, por acción indirecta, a través de la estimulación de la liberación de acetilcolina por los nervios parasimpáticos. También parece incrementar la respuesta broncoconstrictora a la histamina y la metacolina en asmáticos (165). Jandl y col. afirman que en estos pacientes se observa una inducción de la H-PGDS en el compartimento epitelial, de forma que los niveles de $\mathrm{PGD}_{2}$ en el lavado broncoalveolar (BAL) se correlacionan positivamente con la gravedad de la enfermedad. Además, atribuyen a la presencia de los dos tipos de receptores una acción proinflamatoria sobre los macrófagos y los monocitos, mediante la inducción de su migración y su interacción con los neutrófilos, propiciando su desplazamiento al pulmón y aumentando la supervivencia de estos últimos. De esta forma, tanto PTGDR como CRTH2 estarían involucrados en el empeoramiento de la hiperreactividad pulmonar (166).

Luster y Tager describen que la $\mathrm{PGD}_{2}$, además de actuar directamente sobre las células endoteliales, epiteliales y musculares provocando vasodilatación, producción de moco y broncoconstricción, también induce la expresión de quimiocinas como CCL22 en las células epiteliales pulmonares a través del receptor PTGDR, lo que provoca el reclutamiento de células Th2 (167). Pettipher afirma, además, que la activación de PTGDR promueve la polarización de células Th0 a células Th2 a través de la inhibición de la producción de IL-12 en las células dendríticas, y que el CRTH2 media 
el reclutamiento de estas células durante la fase tardía de la respuesta alérgica (168). En ratones $P T G D R^{-/-}$con asma alérgica inducida por ovalbúmina (OVA) se observa una reducción de la inflamación y de la hipersensibilidad, sugiriendo que la $\mathrm{PGD}_{2}$ vía $\mathrm{PTGDR}$ actúa como mediador en la respuesta alérgica (169).

Sin embargo, existen otros estudios que señalan que la acción proinflamatoria de la $P G D_{2}$ se produce cuando se activa el receptor $C R T H 2$, y que la activación del receptor PTGDR tiene efectos antiinflamatorios. Así, Xue y col. también describen una estimulación de la migración y la supervivencia de los neutrófilos en el asma grave por acción de la $\mathrm{PGD}_{2}$ mediante una inducción de la respuesta Th2, pero únicamente lo relacionan con la activación a través de los receptores $\mathrm{CRTH2}$, descartando la implicación de PTGDR (170).

Según Fajt y col., el asma grave se relaciona con una expresión incrementada de $\mathrm{CRTH} 2$, y este, a su vez, se relaciona con las exacerbaciones de la enfermedad, un peor control, la inflamación mediada por células Th2, y la aparición de una eosinofilia más intensa (171). Este receptor también aparece implicado en la infiltración eosinofílica en otras enfermedades como la esofagitis eosinofílica, puesto que los agonistas de CRTH2 generan el mismo efecto, y los antagonistas el contrario. El uso de agonistas de PTGDR como BW245C no incrementa el número de eosinófilos en el epitelio esofágico, lo que descartaría su participación en el proceso (172). Murata y col. apuntan que el agonista de PTGDR (BW245C) incrementa la resistencia transendotelial, lo que provocaría una disminución de la permeabilidad del endotelio (173). Según publican Kobayashi y col., la unión PGD 2 -PTGDR inhibe el aumento de la permeabilidad del endotelio vascular a través de la vía cAMP/PKA/Tiam1/Rac1 (174). 
La administración intratraqueal de BW245 inhibe la migración de las células dendríticas a los nódulos linfáticos en el inicio de una respuesta alérgica pulmonar provocado por la exposición a OVA en experimentos realizados con ratones (175). Se ha demostrado también que el uso de este agonista de PTGDR reduce la inflamación cutánea en la dermatitis atópica interfiriendo en el equilibrio Th1/Th2, probablemente mediante el incremento de IL-10 (176). En la dermatitis o hipersensibilidad por contacto, los ratones deficientes para PTGDR muestran una respuesta cutánea más exacerbada y superior a la de los controles, mostrando un papel inhibitorio de la $\mathrm{PGD}_{2}$ sobre la hipersensibilidad alérgica por contacto a través de este receptor. En estos ratones existen concentraciones mayores de IL-17 y IFN- $\gamma$ junto con un incremento de quimiocinas, como RANTES (CCL5), IP-10 (CXCL10) y eotaxina (CCL11) (177).

La unión de la $\mathrm{PGD}_{2}$ a PTGDR en la membrana del eosinófilo provoca, a través de su interacción con proteínas $\mathrm{Gs} \alpha$, un aumento del $\mathrm{AMPc}$, que disminuye la activación de las células implicadas en la inflamación. Además, aunque la $P G D_{2}$ provoque quimiotaxis de eosinófilos, polimerización de la actina y expresión de CD11b en eosinófilos, este efecto no se reproduce con agonistas de PTGDR, como BW245C, ni se suprime con antagonistas, como BWA868C, por lo que debe ir vía otro receptor (178). Así, el balance entre la actividad inhibitoria o estimuladora de la inflamación de la $\mathrm{PGD}_{2}$ viene determinado por el equilibrio entre la actividad de los receptores PTGDR y CRTH2. En un estudio realizado en basófilos por Yoshimura y col, se demuestra que la utilización de agonistas de CRTH2 provoca un aumento de la concentración intracelular de $\mathrm{Ca}^{2+}$, mientras que el uso de agonistas de PTGDR provoca un efecto inhibitorio sobre la degranulación y migración de los basófilos (179). 
Por último, también existen contradicciones sobre el papel que desempeñan los metabolitos derivados de la $\mathrm{PGD}_{2}$ en el desarrollo de la reacción inflamatoria. Algunos estudios defienden que el metabolito de la $P G D_{2}$, la 15 -Deoxy- $\Delta^{12,14}-\mathrm{PGJ}_{2}$ (15d-PGJ2), actúa como un antiinflamatorio mediante su unión a PPARy (Peroxisome proliferator-activated receptor gamma), que tras su dimerización con RXR (Retinoid $X$ receptor) inhibe la expresión de IL-1 $\beta, \mathrm{IL}-6, \mathrm{TNF}-\alpha, \mathrm{y}$ reduce la producción de especies reactivas del oxígeno (ROS) (180). Se define a este metabolito como un regulador de la intensidad de las reacciones inflamatorias que tiene potentes acciones antiinflamatorias por antagonizar las actividades de NF-KB, STAT3 y AP1 mediante la estimulación del factor de transcripción Nrf2, aunque estos efectos no necesariamente se producen a través de PPARy. También puede inhibir la secreción de citocinas e inducir apoptosis en los linfocitos T (181).

Sin embargo, en sentido contrario, se ha descrito que este mismo metabolito, 15d-PGJ2, induce inflamación y apoptosis de los cardiomiocitos a través del receptor CRTH2 (182). Otro de los productos derivados de la $\mathrm{PGD}_{2}$, el $9 \alpha, 11 \beta-P G F 2$, induce broncoconstricción en los pacientes asmáticos, actuando con efecto vasodilatador, quimiotáctico de eosinófilos, basófilos y células Th2 a través del receptor CP2 o CRTH2 $(183,184)$. Debido a que en los ensayos se utilizan concentraciones de 15d-PGJ2 superiores (1-10 $\mu \mathrm{M})$ a la fisiológica (60-100 nM), algunos autores ponen en duda estos ensayos argumentado que para que este metabolito inhiba la inflamación se tienen que utilizar concentraciones superiores a las que normalmente se producen (185). 


\subsubsection{Estructura del receptor PTGDR}

El receptor PTGDR está codificado por el gen PTGDR, localizado en el cromosoma 14, concretamente en la región 14q22.1 (Figura 20). Tiene un tamaño de 359 aminoácidos, y una masa molecular de 40,27 kDa.

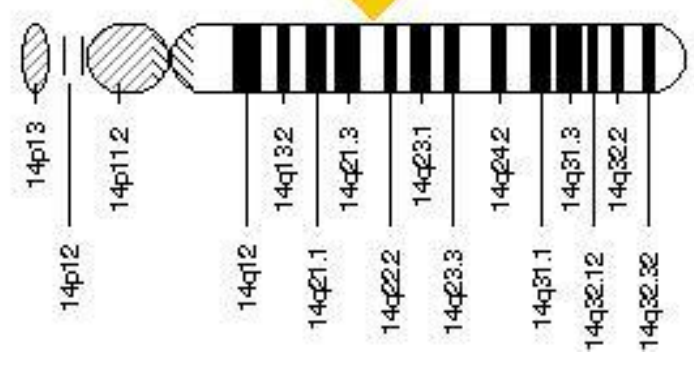

Figura 20: Localización del gen PTGDR dentro del cromosoma 14. La flecha amarilla indica la posición del gen.

Este receptor tiene siete dominios transmembranarios, con un segmento $\mathrm{N}$ terminal extracelular, y una terminación intracelular - $\mathrm{COOH}$ típica de los receptores acoplados a proteínas $\mathrm{G}$ tipo rodopsina (Figura 21). En los lazos extracelulares 1 y 2 , (EL1 y EL2 en la figura 21) se encuentran dos residuos de Cys que forman un puente disulfuro esencial para la estabilización de la conformación del receptor (186). Aparecen tres secuencias consenso para la $\mathrm{N}$-glicosilación en residuos de asparragina (Asn-X-Ser/Thr), uno en la región amino terminal y los otros en los lazos extracelulares 1 y 3, que ejercen un papel importante en el proceso de unión al ligando. También se han descrito seis residuos de serina y treonina, que conforman potenciales sitios de fosforilación, distribuidos en la porción citoplasmática de estos receptores. Estos residuos también son característicos de receptores tipo rodopsina, y 
su fosforilación está relacionada con la capacidad de desensibilización de PTGDR $(187,188)$.

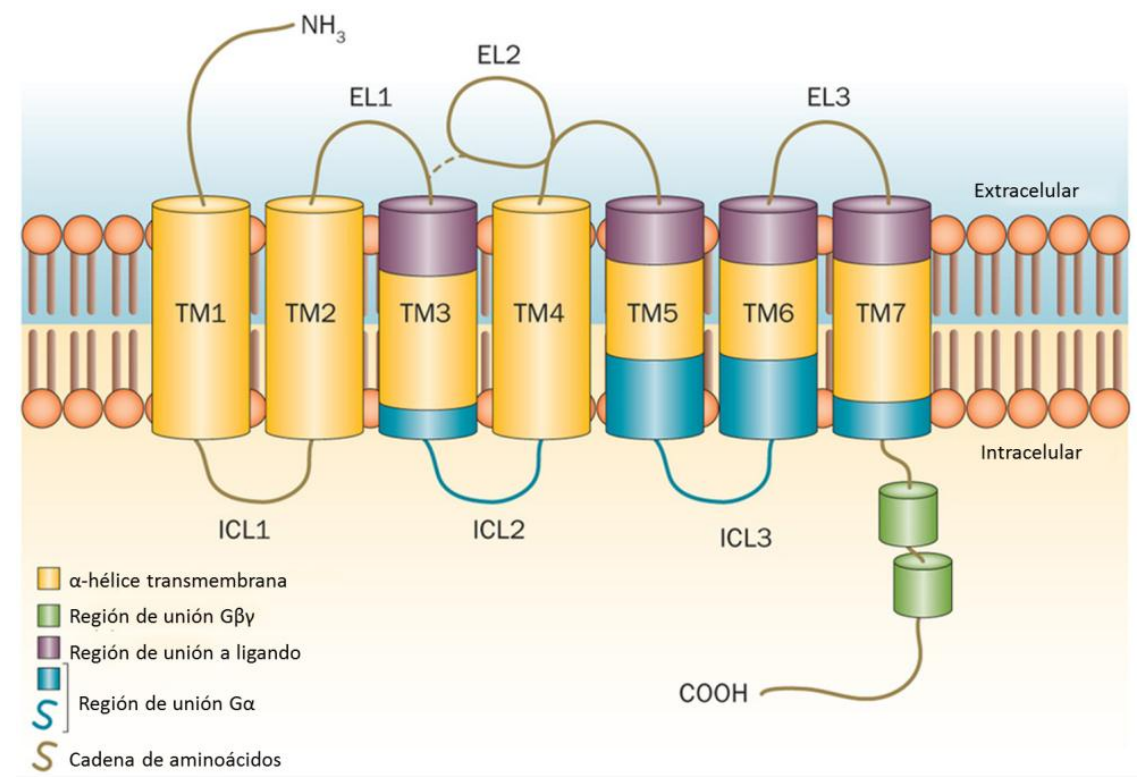

Figura 21: Ejemplo de estructura de receptor acoplado a proteína $G$ con siete dominios transmembranarios. Modificado de (189).

Como se ha comentado anteriormente, realizan su acción a través de su acoplamiento con proteínas $\mathrm{G}$, que estimulan la adenilato ciclasa $(\mathrm{AC})$, con resultado de una elevación de los niveles de AMPc, aunque no se observa una activación de la proteína cinasa A (PKA) (190). No se observa su asociación con el incremento de los niveles de inositol 1-4-5 trifosfato (191).

Mediante la realización de estudios filogenéticos (Figura 22), se ha comprobado que existe un alto grado de similitud entre los receptores de los distintos prostanoides, a excepción de CRTH2, que aparece como el receptor evolutivamente más alejado del resto. Además, se ha comprobado que existe una homología del $88 \%$ entre los 
receptores de prostaglandinas de seres humanos y ratones. En cuanto a la naturaleza del mecanismo de actuación, estos receptores se pueden dividir en dos grupos: aquellos que ponen en marcha cascadas de transmisión de señales a través del AMPc, y aquellos que lo hacen a través del aumento de los niveles de calcio (192).

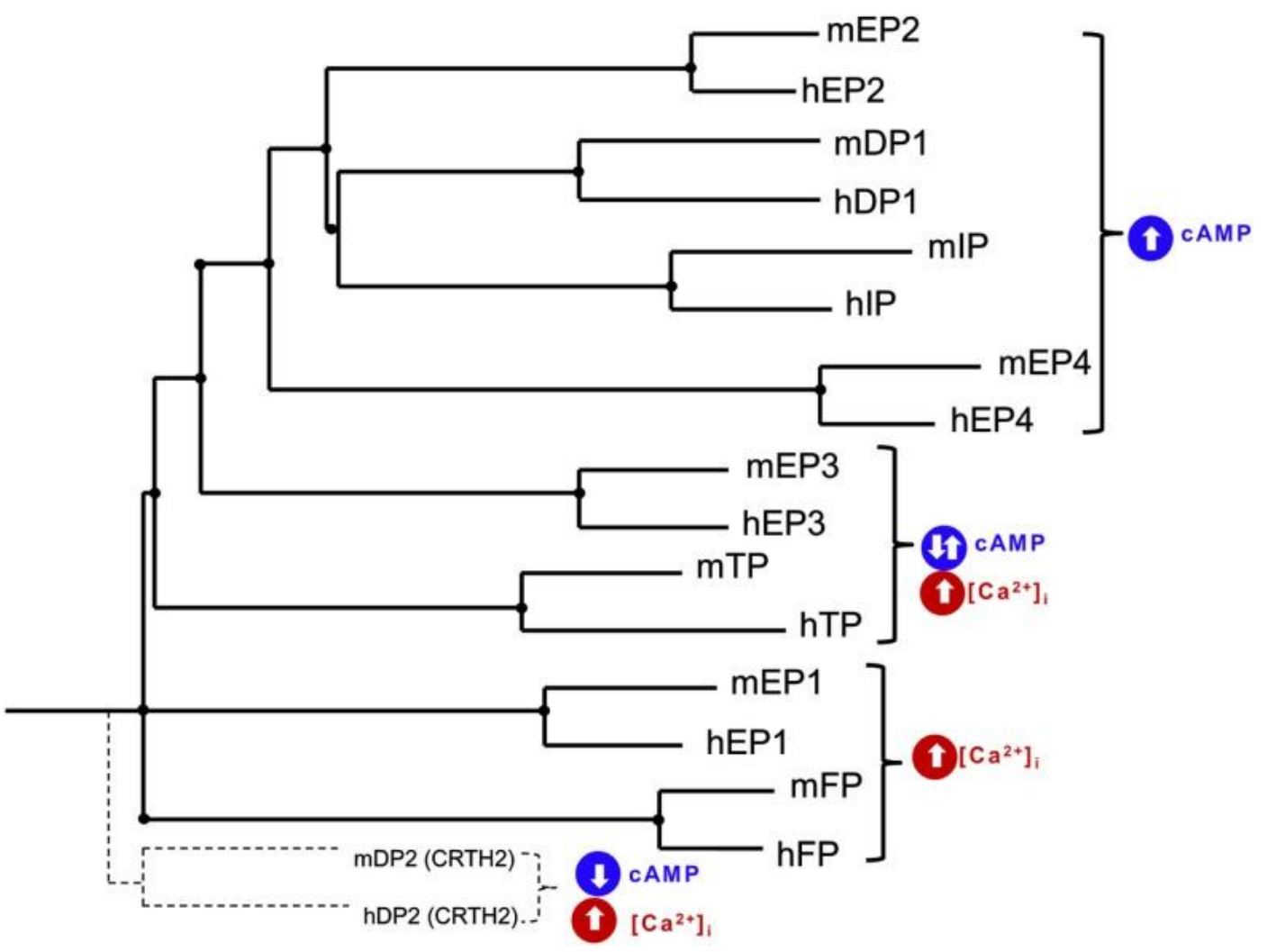

Figura 22: Árbol filogenético de los receptores de prostaglandinas en seres humanos (h) y ratón (m) (192).

\subsubsection{Estudios genéticos de asociación con las enfermedades alérgicas}

En diferentes estudios de ligamiento y asociación se han identificado numerosos marcadores genéticos ligados a patología alérgica en el cromosoma 14, fundamentalmente en la región 14q24 $(193,194)$. Otra región en el cromosoma 14, la 14q13-23, también se ha identificado como una posible candidata a albergar genes 
relacionados con el incremento de IgE en suero total de pacientes asmáticos. Uno de estos marcadores, el D14S63, se encuentra muy próximo al gen PTGDR (195). Estudios transcriptómicos, también identifican a PTGDR, entre otros muchos, como uno de los posibles genes implicados en la apoptosis de eosinófilos, respuesta a alérgenos o interleucinas, y respuesta a corticosteroides inhalados (196). Ungvári y col. establecen una asociación de tres polimorfismos de PTGDR (rs17831682, rs17831675 y rs17125273) con los niveles de IgE y asma (118).

En los últimos años, han sido varios los autores que han publicado estudios en los que relacionan la presencia de determinados polimorfismos en el promotor de PTGDR con la patología alérgica. Oguma y col. describieron tres polimorfismos en la región promotora de PTGDR, concretamente los sitios $-549 \mathrm{~T}>\mathrm{C},-441 \mathrm{C}>\mathrm{T}$ y $-197 \mathrm{~T}>\mathrm{C}$. La presencia de cambios en dichas posiciones provoca modificaciones en la unión de factores de transcripción que aumentan la actividad promotora de PTGDR. Además, relacionaron los polimorfismos $-549 \mathrm{~T}>\mathrm{C}$ y $-441 \mathrm{C}>\mathrm{T}$ con el fenotipo asmático (197).

Posteriormente, Sanz y col. estudiaron la presencia de los polimorfismos $-549 \mathrm{~T}>\mathrm{C},-441 \mathrm{C}>\mathrm{T}$ y $-197 \mathrm{~T}>\mathrm{C}$ en una población caucásica española y corroboraron la asociación de -197T>C con la presencia de asma alérgico. Además, analizando las combinaciones haplotípicas en su población, establecieron una relación entre el haplotipo CCC y el asma (198). En un estudio posterior definieron por primera vez la asociación entre el polimorfismo $-613 \mathrm{C}>\mathrm{T}$ con pacientes alérgicos, y definieron el haplotipo CCCT CCCC (posiciones -613, -549, -441, -197) como más habitual en pacientes asmáticos que en controles (199). Pescador y col. relacionaron estos mismos haplotipos de PTGDR con la presencia de diferentes fenotipos de poliposis nasal, ya 
fuera en solitario o en combinación con asma y con intolerancia a la aspirina (triada de la aspirina) (200).

Grupos como el de Zhu y col, han establecido relación entre otros polimorfismos en la región promotora de PTGDR $(-731 \mathrm{~A}>\mathrm{G})$ y polimorfismos intrónicos (+6541C >T y +6651C >T) con el fenotipo asmático en poblaciones de Reino Unido y Dinamarca (201).

Otro importante mecanismo para la regulación de la expresión génica son las modificaciones epigenéticas, como la metilación, que se asocia con una modificación de la estructura de la cromatina que altera el acceso de los factores de transcripción a sus sitios de unión (202). El grupo de Isidoro-García y col., han descrito una situación de hipometilación del promotor de PTGDR en células B en un grupo de pacientes con asma (203), lo que se correlacionaría con un incremento en el nivel de expresión del receptor.

Sin embargo, los estudios de asociación que relacionan la presencia de polimorfismos en PTGDR con la enfermedad alérgica han generado cierta controversia. Así, existen distintos trabajos en los que no se ha conseguido demostrar esta asociación en ciertos grupos étnicos como mexicanos, costarricenses o africanos (204), ni en la población china o australiana (205-207). Esto puede deberse a problemas con la definición de variables, la caracterización clínica de los grupos a estudio, a problemas técnicos o a que realmente existan diferencias étnicas. 


\subsection{El gen PTGDR y los corticoides.}

Está demostrado que el tratamiento con glucocorticoides modifica las acciones llevadas a cabo por la prostaglandina $\mathrm{D}_{2}$. Así, está publicado que los glucocorticoides suprimen la expresión de la enzima COX-2 en células inmunes (208), y que la dexametasona inhibe la inducción de COX-2 provocada por condiciones de hipoxia (209). También se ha descrito que reduce directamente la síntesis de $P G D_{2}$ en los mastocitos mediante la inhibición de la fosfolipasa A1 $(210,211)$. Además, ciertos metabolitos de la $P G D_{2}$, como $15 \mathrm{~d}-\mathrm{PGJ}_{2}$, pueden interferir en la acción de los glucocorticoides modificando la actividad de su receptor (212).

Aunque sí se ha comprobado la asociación entre algunos polimorfismos de PTGDR con la respuesta a antagonistas de leucotrienos (LTRA) (213), hasta donde hemos podido revisar no hemos encontrado publicaciones que demuestren una relación directa de la presencia de variaciones en la secuencia de PTGDR con la respuesta a glucocorticoides.

Los datos obtenidos hasta el momento relacionan la actividad del receptor PTGDR con los procesos inflamatorios y las reacciones alérgicas. Además, existe evidencia de que la presencia de polimorfismos en su región promotora, así como distintas combinaciones haplotípicas y diplotípicas pueden asociarse con la aparición de la patología asmática y su gravedad. Sin embargo, hoy en día siguen existiendo datos contradictorios sobre el mecanismo de acción de este receptor y su función dentro de la enfermedad.

Es necesario realizar estudios más amplios que permitan dilucidar el papel de PTGDR en el desarrollo y mantenimiento de la enfermedad inflamatoria y el asma, y 
que permitan entender mejor el proceso. Además, puesto que los glucocorticoides constituyen la piedra angular en el tratamiento de estas patologías, sería interesante evaluar la relación del receptor PTGDR con la respuesta a glucocorticoides. 
Efecto de la dexametasona sobre el mecanismo inflamatorio que subyace en el asma 


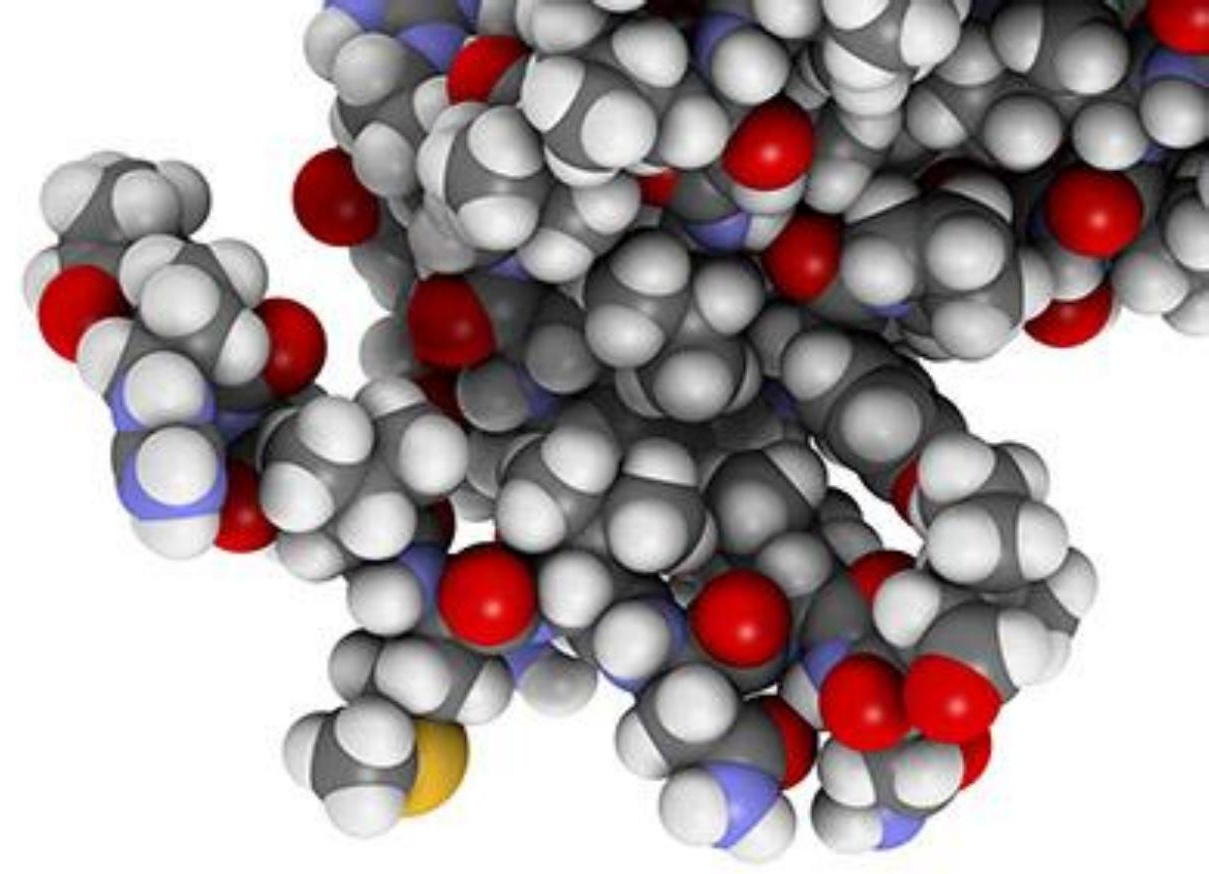

HIPÓTESIS 



\section{HIPÓTESIS}

Dentro del componente genético de la alergia respiratoria, se ha descrito la asociación existente entre los polimorfismos del receptor de la prostaglandina $D_{2}$ (PTGDR) y la respuesta inflamatoria mediada por alérgenos de las vías respiratorias.

La hipótesis principal sobre la que se asienta este trabajo es que los niveles de expresión del gen PTGDR podrían estar relacionados con la presencia de variaciones en su secuencia promotora, que previamente ya han sido asociadas con las características clínico-biológicas de los pacientes con asma.

Además, como hipótesis secundaria se postula que determinadas variantes génicas podrían condicionar la respuesta del gen PTGDR a la acción del tratamiento con corticoides, terapia base de las enfermedades respiratorias alérgicas, en particular el asma. La identificación y caracterización de los mecanismos implicados podría proporcionar importante información sobre las causas de la variación en la respuesta al tratamiento corticoideo que se observa en la práctica clínica. 
Efecto de la dexametasona sobre el mecanismo inflamatorio que subyace en el asma 


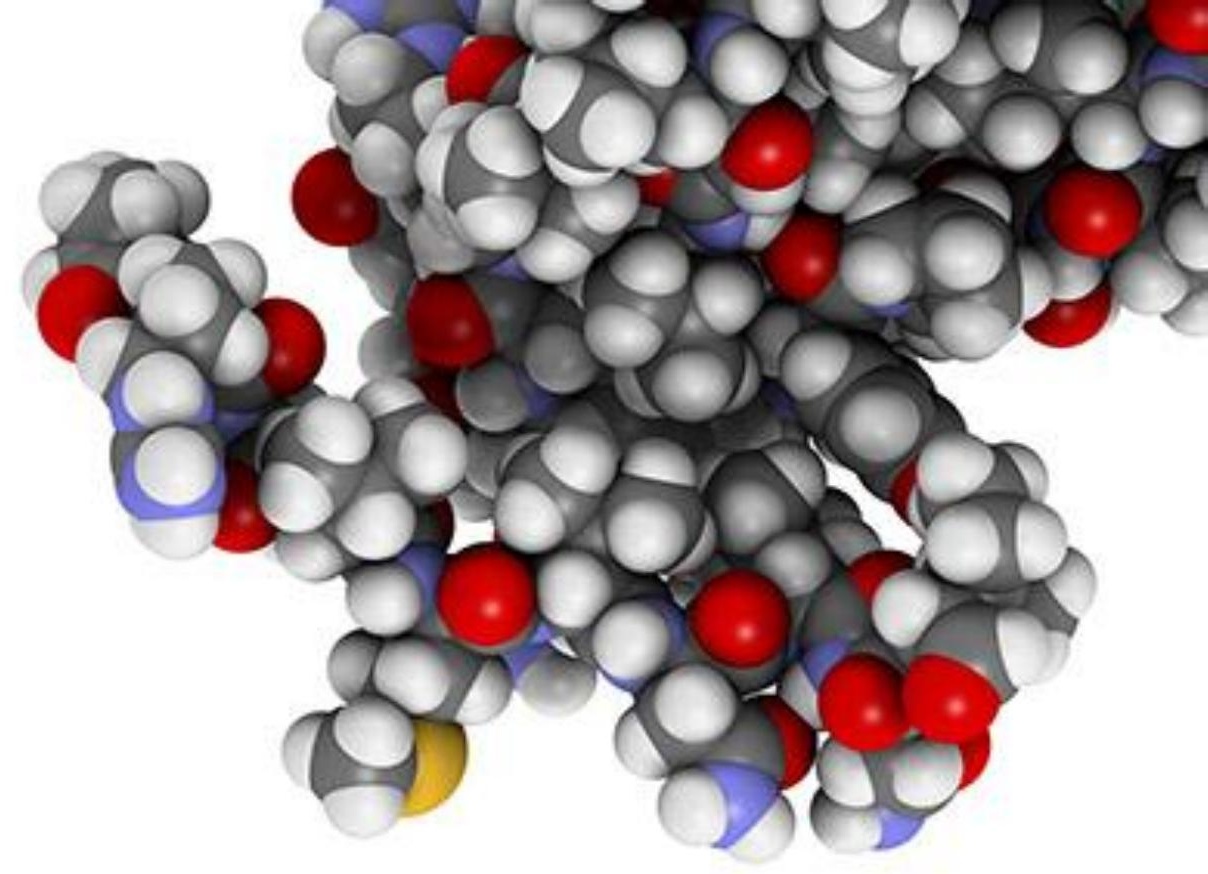

OBJETIV@S 



\section{OBJETIVOS}

1. Desarrollar un sistema celular adecuado para el estudio del efecto del tratamiento corticoideo en la expresión del gen PTGDR.

2. Analizar las diferencias existentes en la actividad promotora del gen PTGDR y en su expresión génica en función de la presencia de distintas variantes polimórficas del mismo.

3. Estudiar el efecto del tratamiento con corticoides sobre la actividad promotora y la expresión génica de PTGDR en función de las variantes génicas objeto de estudio.

4. Identificar posibles sitios de unión de factores de transcripción en la región promotora de PTGDR afectados por la presencia de los polimorfismos.

5. Analizar el posible efecto diferencial de las variantes génicas descritas en la región promotora de PTGDR sobre la expresión de citocinas tras la acción de corticoides en el modelo celular.

6. Diseñar un modelo experimental múrido para el estudio del asma alérgica y analizar la expresión del gen PTGDR tras el tratamiento corticoideo en este modelo.

7. Comparación de los resultados de expresión génica de PTGDR entre ambos modelos experimentales. 
Efecto de la dexametasona sobre el mecanismo inflamatorio que subyace en el asma 



\section{MATERIAL Y MÉTODOS}

\subsection{Técnicas de biología molecular}

\subsubsection{Extracción de ADN genómico}

Las muestras de sangre periférica de los pacientes seleccionados portadores de las combinaciones haplotípicas adecuadas para este estudio se obtuvieron por punción venosa y se recogieron en tubos de vacío con anticoagulante EDTA. Almacenadas las muestras a $-20{ }^{\circ} \mathrm{C}$ hasta su uso, la extracción final de ADN se realizó partir de $1 \mathrm{ml}$ de sangre total, mediante el sistema automatizado MagNA Pure Compact (Roche Applied Science, IN, USA). Este equipo se basa en un sistema de partículas magnéticas que consta de las siguientes fases:

- Lisis celular mediante Tritón X-100 y digestión proteica mediante tampón de lisis y proteinasa $\mathrm{K}$.

- Unión del ADN a la superficie de las partículas de vidrio magnéticas en solución de isopropanol.

- Separación del complejo ADN-partícula magnética.

- Eliminación de los restos celulares mediante varios lavados.

- Separación del complejo ADN-partícula magnética.

- Elución del ADN en $1 \mathrm{ml}$ de Tris-EDTA.

El mismo equipo se utilizó para la extracción de ADN genómico a partir de cultivo celular partiendo de una muestra de 1 millón de células resuspendidas en 100 $\mu l$ de PBS. 


\subsubsection{Discriminación alélica de CYP3A5 en cultivo celular}

La discriminación alélica de CYP3A5 en las células A549 se realizó mediante un análisis de alta resolución de fusión o "High Resolution Melt" (HRM) a través del análisis de las curvas de disociación o curvas melting. Este procedimiento se basa en la detección de pequeñas diferencias en las curvas melting, provocadas por el cambio de una base en la secuencia de DNA amplificada (Figura 23). La presencia de la base conservada o mutada en un polimorfismo concreto generará curvas melting diferentes, pudiendo distinguirse, además, la situación en homocigosis (sólo se generará una curva) o en heterocigosis (se generarán dos curvas).

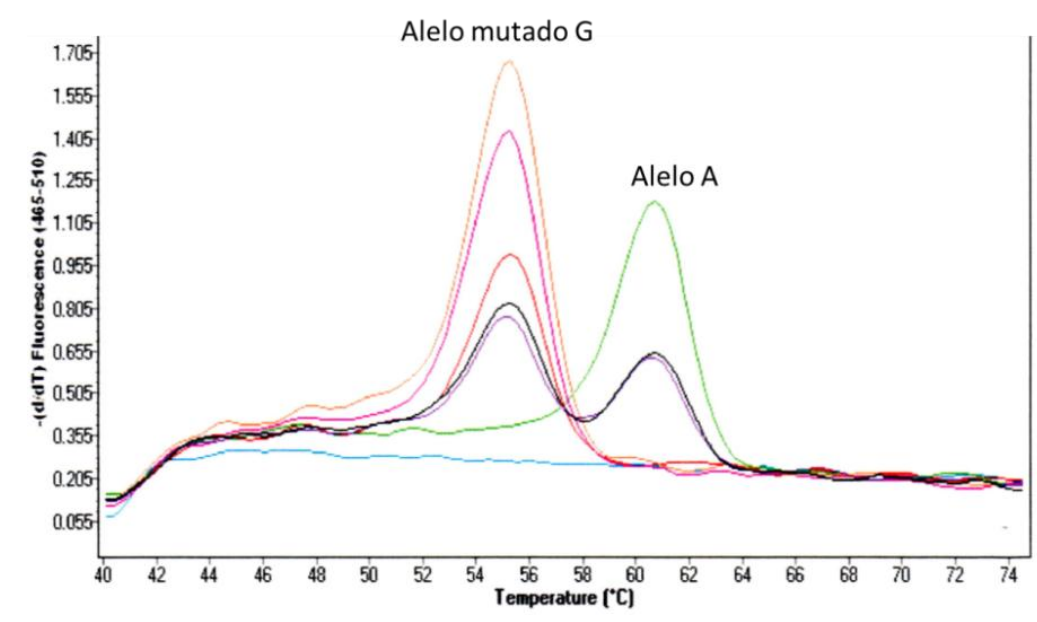

Figura 23: Discriminación alélica de CYP3A5.

Para realizar el análisis, una vez obtenido el ADN de las células A549, se realizó un análisis de PCR a tiempo real empleando sondas FRET, en un equipo "LightCycler 480 System II" (Roche Applied Science, IN, EEUU) utilizando cebadores específicos y sondas adecuadas para las discriminaciones alélicas para el polimorfismo 6986A>Gen el gen CYP3A5. 


\subsubsection{Extracción de ARN de cultivo celular}

La obtención de ARN a partir de las células en cultivo se realizó utilizando el kit comercial RNeasy Plus Mini (Qiagen, Alemania). Este método se basa en la retención de todos los restos de ADN mediante el paso del lisado celular por una columna comercial, la precipitación del ARN utilizando etanol, y la eliminación de contaminantes mediante columnas específicas que retienen el ARN y lavados de la columna con soluciones específicas. De este modo se asegura la purificación todas las moléculas de ARN de más de 200 nucleótidos de longitud.

En todos los casos se partió del lisado de las células cultivadas. Para conseguirlo, una vez retirado el medio de cultivo y tras un lavado de las células con PBS, se añadieron $350 \mu$ de la solución de lisis específica del kit de extracción de ARN (“Buffer RLT"), a cada pocillo. Los lisados se mantuvieron a $-80^{\circ} \mathrm{C}$ hasta su procesamiento.

El ARN final se eluyó en $30 \mu \mathrm{l}$ de agua libre de ARNasas, y se mantuvo a -20 ㄷ para su uso inmediato. Una vez terminado el análisis, las muestras de ARN se almacenaron a $-80 \circ \mathrm{C}$.

Las primeras muestras de ARN obtenidas durante la fase de experimentación fueron tratadas con ADNasa utilizando el reactivo Ambion ${ }^{\circledR}$ TURBO DNA-free ${ }^{\mathrm{TM}}$ Treatment and Removal Reagents (Ambion, Thermo Fisher Scientific, MA, EEUU). Así, se eliminó el ADN añadiendo 2,9 $\mu \mathrm{l}$ de 10x TURBO DNase Buffer y $1 \mu \mathrm{l}$ de la enzima TURBO DNase, e incubando 20-30 minutos a 37으. Pasado este tiempo se paró la reacción con $3 \mu$ de resina de inactivación durante 5 minutos a temperatura ambiente. Por último, se centrifugó y se transfirió el ARN a un tubo limpio. 
Este método provocaba una ligera dilución del ARN, por lo que, para evitarlo, y para evitar la manipulación de esta muestra tan delicada, se optó por continuar el tratamiento con ADNasa utilizando RNase-Free DNase Set (Qiagen, Alemania). Esta nueva fórmula permitió tratar las muestras directamente en la columna de purificación del ARN, antes de la elución.

La calidad del ARN obtenido se midió con el bioanalizador 2100 Bioanalyzer (Agilent Technologies, CA, EEUU), que proporciona un análisis de la integridad del ARN (RNA Integrity Number, RIN). Las muestras analizadas obtuvieron una calificación de 10, que se corresponde con una calidad muy buena ya que se considera que un ARN tiene buena calidad a partir de un RIN de 7.

\subsubsection{Extracción de ARN de tejido pulmonar de ratón}

Para la obtención del ARN a partir del tejido pulmonar de ratón se utilizó el reactivo TRI Reagent ${ }^{\circledR}$ Solution (Ambion, Thermo Fisher Scientific, MA, EEUU). Esta solución permite el aislamiento simultáneo de ARN, ADN y proteínas, pero en este caso sólo se utilizó para aislar ARN.

Las muestras obtenidas en la necropsia de los ratones tras los ensayos agudo y crónico de asma alérgica, se mantuvieron en un eppendorf a -80 ㅇ $\mathrm{C}$ hasta su procesamiento para la extracción de ARN. El tejido congelado se machacó con ayuda de un pistilo hasta reducirlo a polvo dentro de un eppendorf, manteniéndolo en hielo seco. Se añadió $1 \mathrm{ml}$ de reactivo TRI Reagent ${ }^{\circledR}$ Solution para la homogenización del tejido. Este compuesto combina fenol y tiocianato de guanidina, que inhibe la actividad de la ARNasa. El homogeneizado se incubó durante 5 minutos a temperatura 
ambiente y se añadieron $200 \mu \mathrm{l}$ de cloroformo, que provocó la separación del homogeneizado en una fase acuosa (ARN) y una fase orgánica (proteínas), quedando el DNA en la interfase. Se agitó vigorosamente y se incubó durante 5 minutos de nuevo a temperatura ambiente. A continuación se centrifugó la muestra durante 15 minutos, a $12000 \times g$, y a 4 ํ․ La fase acuosa con el ARN se recogió en un tubo limpio y se le añadieron $500 \mu \mathrm{l}$ de isopropanol para la precipitación del ARN. Tras una incubación de 10 minutos, la muestra se centrifugó 12000 x g, 4ํC, durante 8 minutos, y se lavó el pellet generado con $500-1000 \mu \mathrm{l}$ de etanol $70 \%$. Finalmente, tras una nueva centrifugación a 7500 x g durante 5 minutos a 4ํㅡ, el pellet generado se dejó secar y se resuspendió en $30 \mu \mathrm{l}$ de agua libre de nucleasas.

Las muestras de ARN obtenidas se mantuvieron a -80 으 hasta su utilización.

\subsubsection{Sintesis de $A D N$ complementario (ADNc)}

La conversión de ARN a ADNc se realizó utilizando el sistema Superscript ${ }^{\mathrm{TM}}$ III First-Strand Synthesis System for RT-PCR (Invitrogen, Thermo Fisher Scientific, MA, EEUU), que detecta moléculas de ARN de tamaño comprendido entre $100 \mathrm{pb}$ y $12 \mathrm{~kb}$, y puede retrotranscribir desde $1 \mathrm{pg}$ hasta $50 \mu \mathrm{g}$ de RNA. La retrotranscriptasa SuperScript ${ }^{\mathrm{TM}}$ III es capaz de sintetizar ADNc en un rango de temperatura de 42-55으, y debido a que no se inhibe por la presencia de ARN ribosomal ni transferente, puede usarse en muestras de ARN total.

En las reacciones de retrotranscripción se utilizaron como cebadores hexámeros compuestos por una mezcla de hexanucleótidos al azar, que permiten retrotranscribir simultáneamente tanto ARNm como ARNr. Se partió de $1 \mu \mathrm{g}$ de ARN 
total, en un volumen máximo de $8 \mu \mathrm{l}$. En aquellas muestras en las que, por su menor concentración inicial, se superaba este volumen, la cantidad de ARN de partida fue la correspondiente a este volumen máximo, teniéndolo en cuenta en los pasos posteriores.

Siguiendo las indicaciones del fabricante, en primer lugar de desnaturalizó el ARN, junto con la mezcla de hexámeros y dNTP, sometiéndolo a una temperatura de 65ํㄷ durante 5 minutos. Seguidamente, se añadió la mezcla de síntesis de ADNc compuesta por Buffer 10x para RT, $25 \mathrm{mM}$ de $\mathrm{MgCl}_{2}, 0,1 \mathrm{M}$ de DTT, RNase OUT ${ }^{\mathrm{TM}}$ y 1 $\mu$ de enzima SuperScript ${ }^{\mathrm{TM}}$ III $(200 \mathrm{U} / \mu \mathrm{l})$. Se incubó la mezcla final durante 50 minutos a $50^{\circ} \mathrm{C}$ para permitir la síntesis de ADNc, y otros 5 minutos a $85^{\circ} \mathrm{C}$ para terminar la reacción. Finalmente, se eliminaron las hebras de ARN mediante incubación de 20 minutos a $37^{\circ} \mathrm{C}$ con $1 \mu \mathrm{l}$ de RNase $\mathrm{H}(2 \mathrm{U} / \mu \mathrm{l})$. El ADNc obtenido, en un volumen final de $21 \mu \mathrm{l}$, se guardó a -20C hasta su utilización.

Se asumió la retrotranscripción completa del total de ARN añadido a la reacción, por lo que la concentración final de ADNc se calculó dividiendo la cantidad total de ARN entre el volumen final de la reacción de retrotranscripción (214).

Concentración $c D N A(n g / \mu l)=\frac{n g R N A \text { en la reacción }}{21 \mu l}$

\subsubsection{Control de calidad de los ácidos nucleicos extraídos}

Se utilizó un espectofotómetro NanoDrop ${ }^{\circledR}$ ND-1000 (Thermo Fisher Scientific, MA, EEUU). Para el ADN, tanto genómico como plasmídico, se considera una buena 
calidad cuando la ratio $260 / 280$, que indica la ausencia de proteína, se sitúa en torno a 1,8. En el caso del ARN, la ratio 260/280 debe estar en torno a 2.

Además, la ratio 260/230 debe estar entre 2,0-2,2, que nos indicaría que no existe contaminación con soluciones fenólicas que puedan alterar la eficacia de los ensayos posteriores (215).

\subsubsection{Reacción en cadena de la polimerasa (PCR)}

La amplificación de ADN mediante PCR se realizó usando un termociclador modelo Primus 25 de MWG-BIOTECH (Biotech, Alemania), o bien un termociclador Multi Gene Opti Max de LABNET INC (Labnet, NJ, EEUU). La reacción de amplificación se realizó utilizando los cebadores específicos que se muestran en la tabla 4, en un volumen final de $25 \mu \mathrm{l}$. Para cada reacción se añadieron 12,5 $\mu \mathrm{l}$ de PCR Master Mix (Promega, WI, EEUU), 8,5 $\mu \mathrm{l}$ de agua libre de nucleasas, 100-200 ng de ADN y $600 \mathrm{nM}$ de cada cebador (sentido y antisentido).

Tabla 4: Programa de amplificación por PCR utilizado.

\begin{tabular}{|c|c|c|c|}
\hline Programa & Temperatura & \multicolumn{2}{|c|}{ Tiempo } \\
\hline Desnaturalización & $95 \div \mathrm{C}$ & \multicolumn{2}{|l|}{$5 \mathrm{~min}$} \\
\hline \multicolumn{4}{|l|}{ Amplificación } \\
\hline - Desnaturalización & $95 \div \mathrm{C}$ & $1 \mathrm{~min}$ & \multirow{3}{*}{35 ciclos } \\
\hline - Anillamiento & Temperatura específica & $1 \mathrm{~min}$ & \\
\hline - Polimerización & $72 \circ \mathrm{C}$ & $1 \mathrm{~min}$ & \\
\hline Polimerización & $72 \circ \mathrm{C}$ & \multicolumn{2}{|l|}{$3 \min$} \\
\hline
\end{tabular}

*La temperatura idónea de anillamiento se calculó específicamente para cada pareja de cebadores. 


\subsubsection{Electroforesis en gel de agarosa}

Tras la realización de la PCR, se comprobó, tanto el correcto funcionamiento de la amplificación, como el tamaño adecuado de los fragmentos generados, mediante la realización de electroforesis en geles de agarosa. Para la realización de los geles se empleó agarosa Biotools Mb (Biotools B\&M Labs, España) al 1\%, utilizando para ello tampón TBE 10x (Promega, WI, EEUU), compuesto por 890 mM de Tris-borato, 890 mM de ácido bórico y 20 mM de EDTA a pH 8,2-8,4, disuelto al 0,5x con agua destilada. Para la tinción de los ácidos nucleicos se utilizó RedSafe ${ }^{\mathrm{TM}}$ Nucleic Acid Staining Solution [20.000x] (iNtRON Biotechnology, Korea), un agente intercalante que emite fluorescencia a $537 \mathrm{~nm}$ al ser iluminado con luz ultravioleta, añadiendo $3 \mu$ l por cada $100 \mathrm{ml}$ de gel de agarosa, antes de la solidificación del mismo.

En cada gel se cargó el marcador de peso molecular DNA Molecular Weight Marker VIII (Roche Applied Science, Alemania), para comprobar el tamaño de los fragmentos (Figura 24). Se utilizó un volumen de $5 \mu \mathrm{l}$ de cada muestra de PCR junto con $1 \mu$ l de tampón de carga DNA Loading Buffer 6x (Lonza, Suiza).

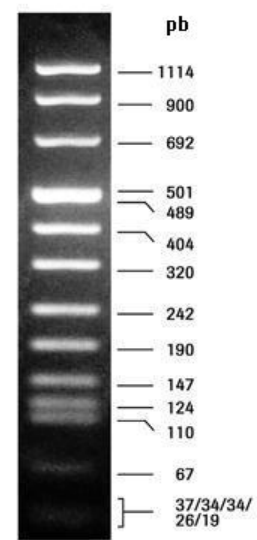

Figura 24: Marcador de peso molecular Marker VIII (Gel de agarosa 2\%). Al lado de cada banda se indica el número de pares de bases $(\mathrm{pb})$ al que corresponde. 
Todas las electroforesis se realizaron aplicando una corriente de 120 voltios durante 20-30 minutos, pudiendo alargarse el tiempo en función de la correcta separación de los fragmentos de ADN. Se utilizó el transiluminador de luz ultravioleta VisiDoc-It ${ }^{\mathrm{TM}}$ Imaging System (Uplant, CA, EEUU) para el análisis de los resultados de cada electroforesis.

\subsubsection{Purificación de los fragmentos amplificados por $P C R$}

Antes de llevar a cabo la secuenciación de los fragmentos amplificados por PCR, fue necesario eliminar los restos de nucleótidos y cebadores no incorporados, ya que podrían interferir en la secuenciación y el análisis de polimorfismos. Con este fin, se trataron las muestras post-PCR utilizando el método ExoSAP-IT (USB, OH, EEUU), basado en la acción conjunta de dos enzimas. La Exonucleasa I (Exol) se encarga de eliminar los restos de cebadores, mientras que la Fosfatasa Alcalina (SAP) de camarón boreal degrada los dNTP que no han sido consumidos en la reacción.

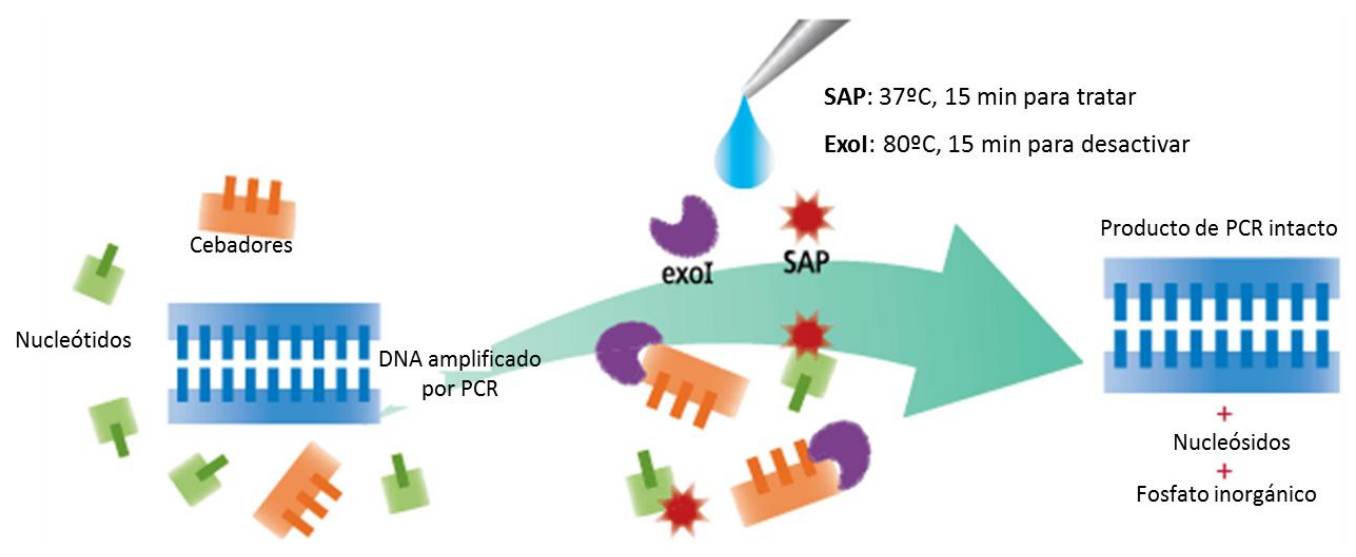

Figura 25: Mecanismo de acción del método ExoSAP-IT. Modificado de (216).

Es un procedimiento rápido, que requiere una incubación durante 15 minutos a $37^{\circ} \mathrm{C}$, en la que ejercen su acción la Exol y la SAP de limpieza del producto de PCR, y 
otra posterior de 15 minutos a $80^{\circ} \mathrm{C}$, donde se inactivan las enzimas del ExoSAP-IT (Figura 25).

Para cada muestra, se utilizaron $4 \mu \mathrm{l}$ de PCR a los que se les añadió $1 \mu \mathrm{l}$ de ExoSAP-IT, resultado un volumen final de muestra purificada de $5 \mu$ l. El programa de purificación se llevó a cabo usando un termociclador MWG-BIOTECH (Biotech, Alemania).

\subsubsection{Secuenciación automática de $A D N$}

Se partió de dos tipos de muestras. Por un lado, para el análisis de los polimorfismos del promotor del gen PTGDR en muestras procedentes de sangre de pacientes y muestras procedentes de cultivo celular, se utilizaron los productos amplificados por PCR a partir de ADN genómico. Por otro lado, para la comprobación de los vectores de clonación, se emplearon directamente los plásmidos purificados mediante MaxiPrep. En ambos casos, la secuenciación de ADN se llevó a cabo en un secuenciador automático ABI PRISM 377 ADN Sequencer (Thermo Fisher Scientific, MA, EEUU).

En las dos situaciones se utilizaron los cebadores específicos correspondientes (Tabla 6), así como terminadores marcados con cromóforos fluorescentes y la enzima Taq polimerasa (Thermo Fisher Scientific, MA, EEUU), siguiendo las instrucciones del fabricante.

En el primero de los casos, los $5 \mu$ l de muestra de PCR purificada resultante del tratamiento con ExoSAP-IT se prepararon añadiendo $3 \mu$ de cebador a una concentración de $1 \mu \mathrm{M}$. 
En el segundo de los casos, los vectores de clonación se diluyeron en agua libre de nucleasas hasta una concentración de 80-120 ng/ $\mu$ l. En la reacción para la secuenciación se utilizaron 400-600 ng total de plásmido y los cebadores universales M13.

\subsubsection{1. $P C R$ a tiempo real o PCR cuantitativa ( $q P C R$ )}

El ADNc obtenido a partir de la retrotranscripción de ARN se amplificó mediante PCR a tiempo real en un equipo LightCycler ${ }^{\circledR} 480$ System II (Roche Applied Science, IN, EEUU), utilizando como fluoróforo SYBR Green I.

Cada reacción de amplificación se elaboró con 20 ng de ADNc, 7,5 $\mu$ l de Master Mix SYBR Green I $2 X$ (Roche Applied Science, IN, EEUU), los correspondientes cebadores a una concentración final de 400 nM, y agua libre de nucleasas hasta un volumen final de $15 \mu \mathrm{l}$ totales. Además, cada situación experimental se analizó por triplicado, en pocillos independientes.

El programa de amplificación utilizado se describe en la tabla 5.

Tabla 5: Programa de amplificación en los ensayos de PCR a tiempo real.

\begin{tabular}{|c|c|c|c|c|}
\hline Programa & Temperatura & Tiempo & \multicolumn{2}{|l|}{ Rampa Tạ } \\
\hline Activación Taq Polimerasa & $95 \div C$ & $10 \mathrm{~min}$ & \multicolumn{2}{|l|}{4,4 으/seg } \\
\hline \multicolumn{5}{|l|}{ Amplificación } \\
\hline - Desnaturalización & $95 \div \mathrm{C}$ & $10 \mathrm{seg}$ & $4,4 \stackrel{\circ}{ } \mathrm{C} / \mathrm{seg}$ & \multirow{3}{*}{45 ciclos } \\
\hline - Anillamiento & $60 \div \mathrm{C}$ & $10 \mathrm{seg}$ & $2,2 \circ \mathrm{C} / \mathrm{seg}$ & \\
\hline - Polimerización & $72 \circ \mathrm{C}$ & $10 \mathrm{seg}$ & $4,4 \stackrel{\circ}{ } \mathrm{C} / \mathrm{seg}$ & \\
\hline Melting curve & $97 \div \mathrm{C}$ & & \multicolumn{2}{|l|}{0,11 으/seg } \\
\hline Enfriamiento & $40 \div C$ & $30 \mathrm{seg}$ & \multicolumn{2}{|l|}{$2,2^{\circ} \mathrm{C} / \mathrm{seg}$} \\
\hline
\end{tabular}




\section{- Método de cuantificación.}

Para el análisis de la expresión se utilizó un método de cuantificación relativa, el método $\Delta \Delta \mathrm{C}_{\mathrm{T}}$ (comparación de $\mathrm{C}_{\mathrm{T}}$ ), que nos permitió cuantificar diferencias en la expresión de los genes problema entre las diferentes muestras. Se siguieron las directrices publicadas en el manual "Guide to Performing Relative Quantitation of Gene Expression Using Real-Time Quantitative PCR" (214).

El método $\Delta \Delta \mathrm{C}_{\mathrm{T}}$ se basa en la comparación del ciclo umbral $\mathrm{C}_{\mathrm{T}}$ (Threshold Cycle, ciclo de amplificación en el que se supera la línea base) de la muestra problema, primero frente a un gen de referencia o control endógeno, $y$, posteriormente, frente $a$ una muestra que actúa como condición basal del ensayo. El gen de referencia o control endógeno permite normalizar la cuantificación de la expresión de los genes diana y evitar, así, las desviaciones que pueden provocar pequeñas variaciones en la cantidad total de ácido nucleico añadido a cada reacción. En nuestro caso, se seleccionó como gen de referencia el gen constitutivo GAPDH (Gliceraldehido-3-fosfato deshidrogenasa), ampliamente avalado en la bibliografía.

De cada una de las muestras se realizaron tres replicados idénticos, es decir, cada una de las mezclas de reacción se amplificó en tres pocillos distintos, a fin de monitorear la precisión de la amplificación. Para el cálculo del $\Delta \Delta \mathrm{C}_{\mathrm{T}}$ se utilizaron las medias de los valores de $C_{T}$ de estos tres replicados, verificando que la desviación estándar no fuera superior a 0,3, y eliminando aquellos triplicados que se desviaron demasiado.

En primer lugar se calculó el $\Delta \mathrm{C}_{\mathrm{T}}$ según la fórmula: 
$\Delta \mathrm{C}_{\mathrm{T}}=\mathrm{C}_{\mathrm{T}}$ gen problema $-\mathrm{C}_{\mathrm{T}}$ gen de referencia

El cálculo del $\Delta C_{T}$ debe realizarse partiendo de la misma muestra, en la que medimos la expresión de los dos genes.

Una vez calculado el $\Delta C_{T}$, se calculó el $\Delta \Delta C_{T}$ según la fórmula:

$\Delta \Delta \mathrm{C}_{\mathrm{T}}=\Delta \mathrm{C}_{\mathrm{T}}$ muestra problema $-\Delta \mathrm{C}_{\mathrm{T}}$ muestra basal

En los ensayos de expresión, la muestra problema fue aquella que provenía de células tratadas con dexametasona, y la muestra basal la que se obtuvo de células tratadas con el vehículo del corticoide (etanol), en el mismo punto temporal.

El dato final de expresión relativa de nuestra muestra problema se calculó de acuerdo con la fórmula:

Expresión relativa $=2^{-\Delta \Delta C T}$

\subsubsection{Diseño, síntesis y cálculo de la eficiencia de los cebadores}

A excepción de los cebadores destinados a la detección de Mycoplasma en cultivos celulares y los cebadores para la secuenciación del inserto clonado en los vectores de transfección, el resto de los cebadores que se han utilizado, tanto en PCR convencional como en PCR cuantitativa, fueron diseñados por nuestro grupo (Tabla 6). Se utilizaron los software "Primer3", "Universal Probe Library Assay Design Center" y "Beacon Designer", para su diseño y para la comprobación de sus temperaturas de anillamiento, la cantidad de bases GC y la ausencia de estructuras secundarias que pudieran interferir en su estabilidad. 
Tabla 6: Secuencias de los cebadores utilizados en los diferentes ensayos.

\begin{tabular}{|c|c|c|c|}
\hline & Objetivo & Primer & Secuencia $5^{\prime} \rightarrow 3^{\prime}$ \\
\hline \multirow{4}{*}{ 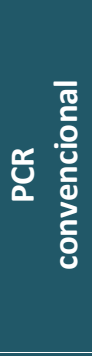 } & \multirow{2}{*}{$\begin{array}{c}\text { Detección } \\
\text { Mycoplasma en cultivo } \\
\text { celular }\end{array}$} & $\begin{array}{c}\text { Mico1 } \\
\text { Forward }\end{array}$ & GGCGAATGGGTGAGTAACACG \\
\hline & & $\begin{array}{c}\text { Mico2 } \\
\text { Reverse }\end{array}$ & CGGATAACGCTTGCGACTATG \\
\hline & \multirow{2}{*}{$\begin{array}{c}\text { Amplificación inserto } \\
\text { de promotor de PTGDR } \\
\text { añadiendo dianas } \\
\text { Xhol/Bglll }\end{array}$} & $\begin{array}{l}\text { PTGDR-Xhol } \\
\text { Forward }\end{array}$ & CTCGAGCTCAGTTTCCTCGCCTATGC \\
\hline & & $\begin{array}{l}\text { PTGDR-BgIII } \\
\text { Reverse }\end{array}$ & AGATCTGAGTGAAGGCTGCGGAAGG \\
\hline \multirow{4}{*}{ 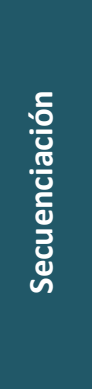 } & \multirow{2}{*}{$\begin{array}{c}\text { Secuenciación } \\
\text { promotor PTGDR } \\
\text { humano }\end{array}$} & $\begin{array}{l}\text { PTGDR } \\
\text { Forward }\end{array}$ & CTCAGT TTCCTCGCCTATGC \\
\hline & & $\begin{array}{l}\text { PTGDR } \\
\text { Reverse }\end{array}$ & GAGTGAAGGCTGCGGAAGGG \\
\hline & \multirow{2}{*}{$\begin{array}{c}\text { Comprobación inserto } \\
\text { en vector }\end{array}$} & $\begin{array}{l}\text { M13 Forward } \\
\text { (Universal) }\end{array}$ & TGTAAAACGACGGCCAGT \\
\hline & & $\begin{array}{l}\text { M13 Reverse } \\
\text { (Universal) }\end{array}$ & AACAGCTATGACCATG \\
\hline \multirow{10}{*}{ 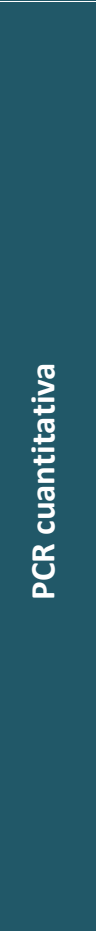 } & \multirow{2}{*}{$\begin{array}{l}\text { Expresión GAPDH } \\
\text { humano }\end{array}$} & $\begin{array}{l}\text { GAPDH } \\
\text { Forward }\end{array}$ & СTCTGCTCCTCCTGTTCGAC \\
\hline & & $\begin{array}{l}\text { GAPDH } \\
\text { Reverse }\end{array}$ & ACGACCAAATCCGTTGACTC \\
\hline & \multirow{2}{*}{$\begin{array}{c}\text { Expresión GAPDH } \\
\text { ratón }\end{array}$} & $\begin{array}{l}\text { GAPDH ratón } \\
\text { Forward }\end{array}$ & CGACTTCAACAGCAACTCCСАСТCTTCC \\
\hline & & $\begin{array}{l}\text { GAPDH ratón } \\
\text { Reverse }\end{array}$ & TGGGTGGTCCAGGGTTTCTTACTCCTT \\
\hline & \multirow{2}{*}{$\begin{array}{c}\text { Expresión PTGDR } \\
\text { humano }\end{array}$} & $\begin{array}{l}\text { PTGDR qPCR } \\
\text { Forward }\end{array}$ & GGCATGAGGCCTAAAAATGAG \\
\hline & & $\begin{array}{l}\text { PTGDR qPCR } \\
\text { Reverse }\end{array}$ & CCTTGACATCCTTAAATGCTCC \\
\hline & \multirow{2}{*}{$\begin{array}{c}\text { Expresión } P T G D R \\
\text { ratón }\end{array}$} & $\begin{array}{l}\text { PTGDR ratón } \\
\text { Forward }\end{array}$ & GACGGTCACCGACTTGCTGG \\
\hline & & $\begin{array}{l}\text { PTGDR ratón } \\
\text { Reverse }\end{array}$ & AGCCCAAAGAAGGACATCAGGAA \\
\hline & \multirow{2}{*}{ Expresión CYP3A5 } & CYP3A5 Forward & TGGACTITTTAAGAGACTGGGAAT \\
\hline & & CYP3A5 Reverse & TCAAATTTCCAGAGACCCTGA \\
\hline
\end{tabular}

Se diseñaron a partir de las secuencias de sus genes específicos depositadas en la base de datos "USCS Genome Browser" (http://genome.ucsc-edu/). La especificidad se comprobó mediante la realización de alineamientos frente a la totalidad del genoma humano a través del programa "BLAST", de la plataforma NCBI 
(http://blast.ncbi.nlm.nih.gov/Blast.cgi). De esta forma se comprobó que únicamente amplificaban la región génica de interés.

Todos los cebadores fueron suministrados por Roche Applied Science (España), en forma de liofilizado, y reconstituidos con agua libre de endonucleasas y almacenados a $-20 \circ \mathrm{C}$.

A través del cálculo de la pendiente en fase logarítmica en una qPCR se comprobó que la eficiencia de los cebadores estaba comprendida entre $90-100 \%$, según la fórmula:

$$
\text { Eficiencia }=\left(10^{(-1 / \text { pendiente })}-1\right) \times 100
$$

Para el análisis de la eficiencia se utilizaron diluciones seriadas de una muestra de ADNc de células cultivadas sin ningún tratamiento, con un rango de concentraciones entre $100 \mathrm{ng} / \mu \mathrm{l}$ y 0,39 $\mathrm{ng} / \mu \mathrm{l}$ (Figura 26).

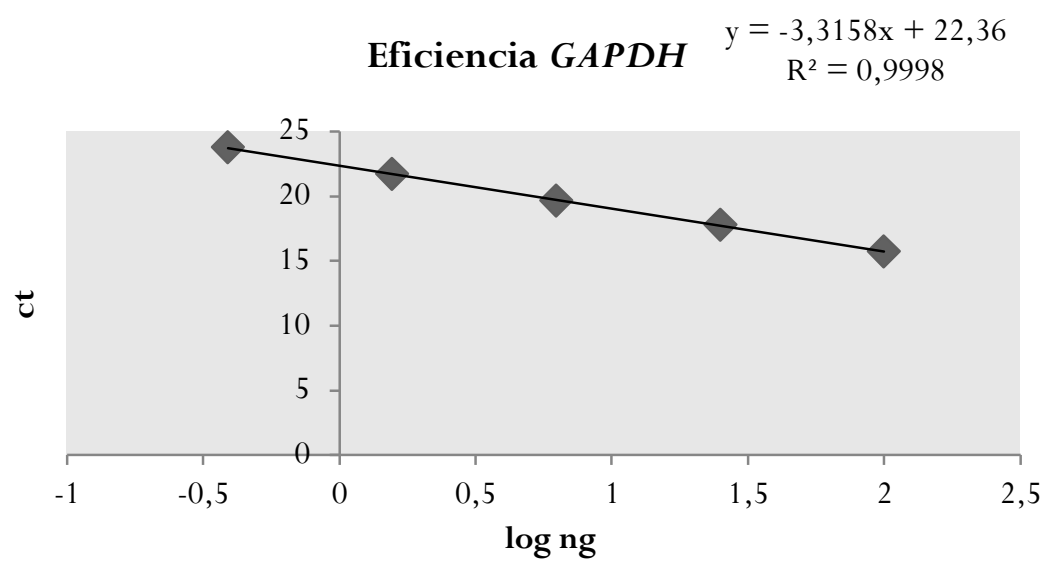

Figura 26: Ejemplo de curva para el cálculo de eficiencia para los cebadores de GAPDH humano 


\subsubsection{Estudio in silico de las variantes polimórficas del promotor de PTGDR}

En este abordaje in silico se utilizaron dos algoritmos informáticos distintos para establecer posibles diferencias entre las variantes del promotor del gen PTGDR en base a los cambios polimórficos $-613 \mathrm{C}>\mathrm{T},-549 \mathrm{~T}>\mathrm{C},-441 \mathrm{C}>\mathrm{T}$ y $-197 \mathrm{~T}>\mathrm{C}$. Estos dos programas informáticos fueron MatInsprector (Genomatix Software GmbH) (www.genomatix.de) y Transfac (Biobase) (http://www.gene-regulation.com/). Ambos programas emplean distintos algoritmos, mediante los cuales proponen una serie de factores de transcripción candidatos a interaccionar con la secuencia introducida. En este estudio fueron evaluadas tanto las posiciones conservadas como los polimorfismos con el fin de comparar los resultados obtenidos en los análisis.

\subsection{Modelo celular}

\subsubsection{Selección de polimorfismos y generación de los insertos para clonación}

El objetivo que se planteó en el diseño del modelo experimental fue reproducir una situación que se aproximara lo máximo posible al contexto genético de los pacientes que presentan asma $(198,199)$. Para ello, se seleccionaron las cuatro combinaciones haplotípicas de la región promotora del gen PTGDR que con más frecuencia aparecen en estos pacientes. Los polimorfismos implicados en estas combinaciones son los siguientes: $-613 \mathrm{C}>\mathrm{T},-549 \mathrm{~T}>\mathrm{C},-441 \mathrm{C}>\mathrm{T}$ y $-197 \mathrm{~T}>\mathrm{C}$, y sus números de referencia se indican en la tabla 7. 
Tabla 7: Números de referencia (rs) de los polimorfismos de PTGDR a estudio.

\begin{tabular}{|c|c|}
\hline Polimorfismo PTGDR & rs \\
\hline$-613 C>T$ & 34236606 \\
\hline$-549 T>C$ & 8004654 \\
\hline$-441 C>T$ & 803010 \\
\hline$-197 T>C$ & 11157907 \\
\hline
\end{tabular}

Se seleccionaron cuatro pacientes que acudieron al Servicio de Inmunoalergia del Complejo Asistencial Universitario de Salamanca y que eran portadores de las combinaciones haplotípicas de interés en homocigosis en el promotor de PTGDR: CTCT, CCCT, TCCT y CCCC (posiciones respectivas $-613,-549,-441$ y -197 ). En todos los casos se siguieron las normas legales para Estudios Clínicos en España y las del Comité de Ética del Complejo Asistencial Universitario de Salamanca, previa firma del consentimiento informado por todos los participantes en el estudio.

Mediante la realización de técnicas de PCR (reacción en cadena de la polimerasa), utilizando cebadores específicos (Tabla 6), se generó un amplicón de 653 pares de bases del promotor de PTGDR que contenía las cuatro posiciones polimórficas seleccionadas (Figura 27). Además, se añadieron las secuencias de reconocimiento (o dianas) de las enzimas de restricción Xhol y $\mathrm{Bg} / \mathrm{ll}$ en los extremos del amplicón, para facilitar su inserción en distintos vectores. Los fragmentos amplificados se secuenciaron para comprobar que el resto de la secuencia presentaba una conformación de tipo silvestre (wild type). 


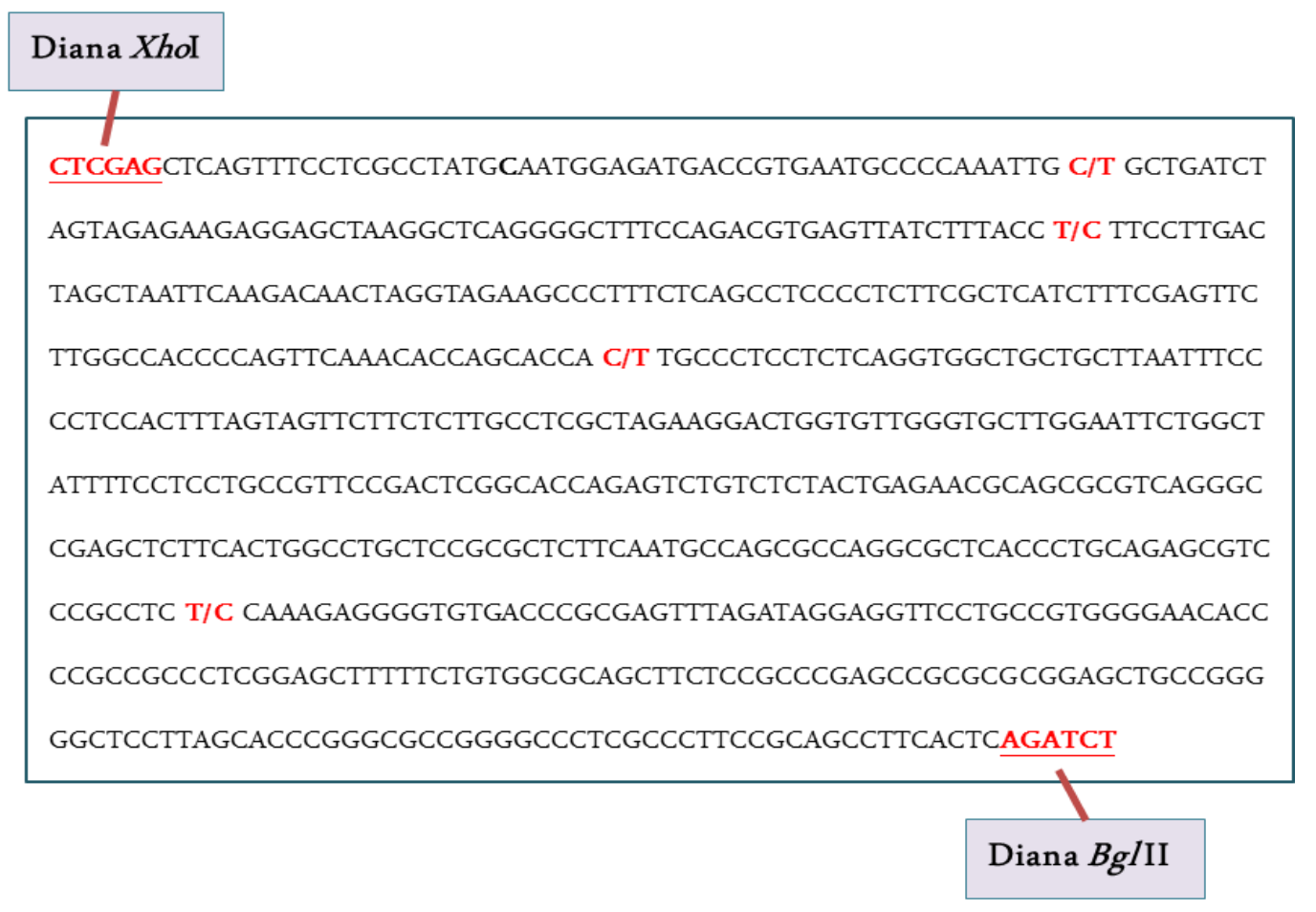

Figura 27: Secuencia del amplicón de PTGDR utilizado para la creación de los vectores específicos. En color rojo subrayado se marcan las dianas utilizadas en la clonación. En color rojo sin subrayar se marcan los polimorfismos a estudio.

\subsubsection{Plásmidos}

- Vectores utilizados en los ensayos de transfección

En los ensayos de transfección celular se utilizaron diversos vectores. En algunos casos fue necesario realizar modificaciones sobre plásmidos comerciales, a fin de satisfacer nuestros requisitos experimentales. Se detallan a continuación:

\section{Vector pSC-A-amp/kan}

Mediante el sistema Strataclone ${ }^{\mathrm{TM}}$ PCR Cloning kit (Stratagene, Agilent Technologies, CA, EEUU), se utilizó el vector pSC-A-amp/kan (Figura 28) para clonar los fragmentos resultantes de la amplificación por PCR que portaban las cuatro variantes 
de la secuencia promotora de PTGDR. Este método de clonación se basa en la unión del residuo de adenina libre en el extremo 3' del producto de PCR generado por la Taq polimerasa, con los residuos de uracilo libres del vector pSC-A-amp/kan linearizado.

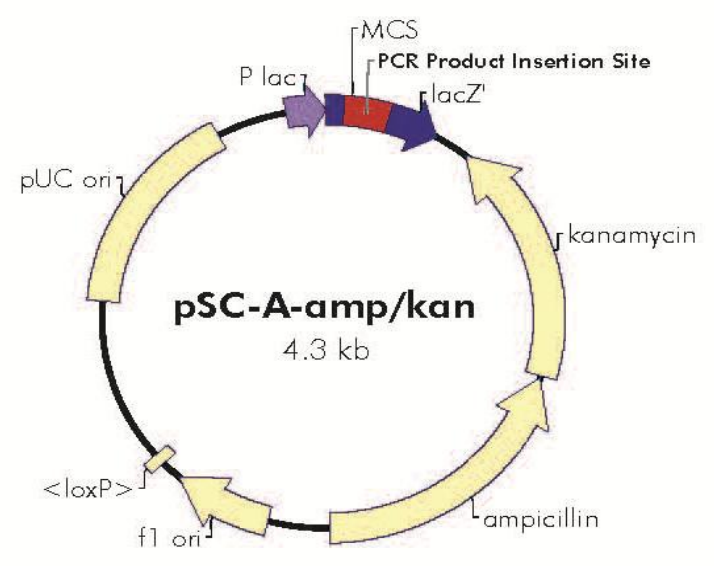

Figura 28: Esquema del vector pSC-A-amp/kan, utilizado para la clonación de los productos de PCR.

\section{Vector pGL3-Basic y modificaciones}

El vector pGL3-Basic (Promega, WI, EEUU) contiene el gen reportero de la luciferasa (luct) de luciérnaga (Photinus pyralis), precedido de un sitio de clonaje múltiple donde se pueden insertar secuencias potencialmente moduladoras de la transcripción génica, tales como promotores, potenciadores (enhancers), etc. De esta forma, la actividad luciferasa estará regulada por la secuencia promotora insertada en sentido 5' del inicio del gen (Figura 29).

En este estudio se utilizó el vector pGL3-Basic para subclonar los insertos introducidos en pSC-A-amp/kan, correspondientes a las secuencias de cuatro variantes polimórficas del promotor de PTGDR. Estos insertos de 653 pares de bases se clonaron utilizando las secuencias de reconocimiento de las enzimas de restricción Xhol y Bg/ll (Roche Applied Science, Alemania), introducidos mediante cebadores específicos 
durante en la PCR. De esta forma, se obtuvieron cuatro vectores portadores el gen reportero de la luciferasa (luct), controlado por las cuatro secuencias a estudio.

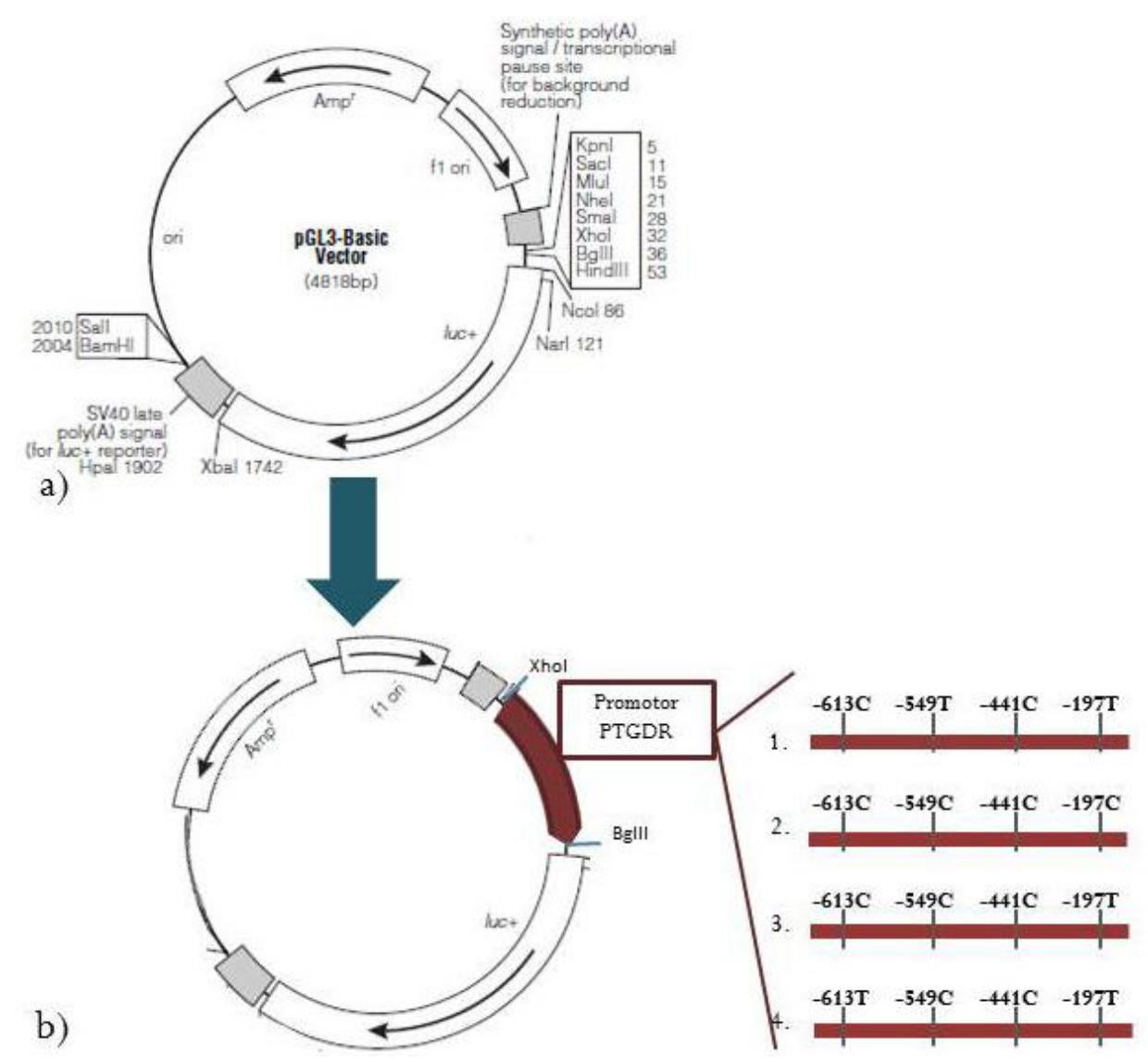

Figura 29: Vector pGL3-Basic y modificaciones. a) Esquema del vector pGL3-Basic. b) Clonación de las secuencias polimórficas del promotor de PTGDR en el vector pGL3-basic.

\section{Vector pRL-SV40}

El vector pRL-SV40 (Promega, WI, EEUU) codifica el gen de la luciferasa Renilla (Renilla reniformis) bajo el control del promotor de expresión fuerte SV40, que le confiere un elevado nivel de expresión (Figura 30). Este vector se utilizó en la estandarización de la señal de luciferasa de luciérnaga (vector pGL3-Basic), realizando co-transfecciones de ambos vectores para reducir la variación inter- e intra-ensayo. 
Estas variaciones pueden provenir de pequeñas alteraciones en el número de células sembradas, de diferencias en la eficiencia del proceso de transfección o de fallos en los procedimientos de medida. La señal proporcionada por la luciferasa Renilla se correlaciona de forma lineal con la expresión de la luciferasa de luciérnaga, por lo que se utilizó como control interno de cada experimento.

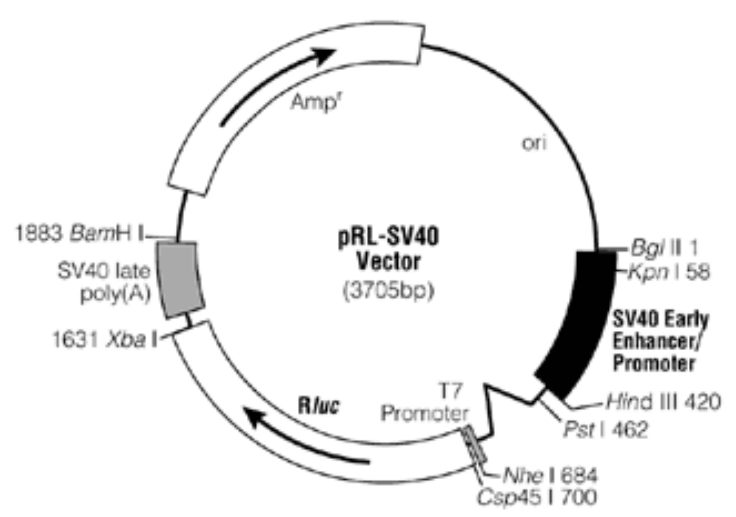

Figura 30: Esquema del vector pRL-SV40.

\section{Vectores de expresión con PTGDR}

Se partió del vector RC208087 (OriGene, MD, EEUU), que contiene y expresa la secuencia codificante del gen PTGDR (NM_000953) insertado en un vector pCMV6entry. Es un vector de expresión en mamíferos, con un tamaño total de $5.9 \mathrm{~kb}$, y con el promotor de Citomegalovirus (CMV) que permite la expresión constitutiva de PTGDR. El promotor SV40 permite la expresión del gen de resistencia a Kanamicina/Neomicina, como marcador de selección.

Se sustituyó el promotor constitutivo de CMV por la secuencia del promotor de PTGDR con las distintas combinaciones polimórficas, partiendo de los vectores generados del mismo modo con pGL3-Basic, utilizando las dianas de las enzimas de 
restricción Xhol y Bg/ll que flanquean estas secuencias. Así, se obtuvieron cuatro vectores distintos, cada uno de ellos con un inserto de 653 pares de bases, portadores de una de las cuatro variantes haplotípicas del promotor de PTGDR: CTCT, CCCC, CCCT o $\operatorname{TCCT}(-653,-549,-441,-197)$. En estos vectores, por tanto, se consigue que la expresión del gen PTGDR esté bajo el control de las secuencias promotoras de interés (Figura 31).
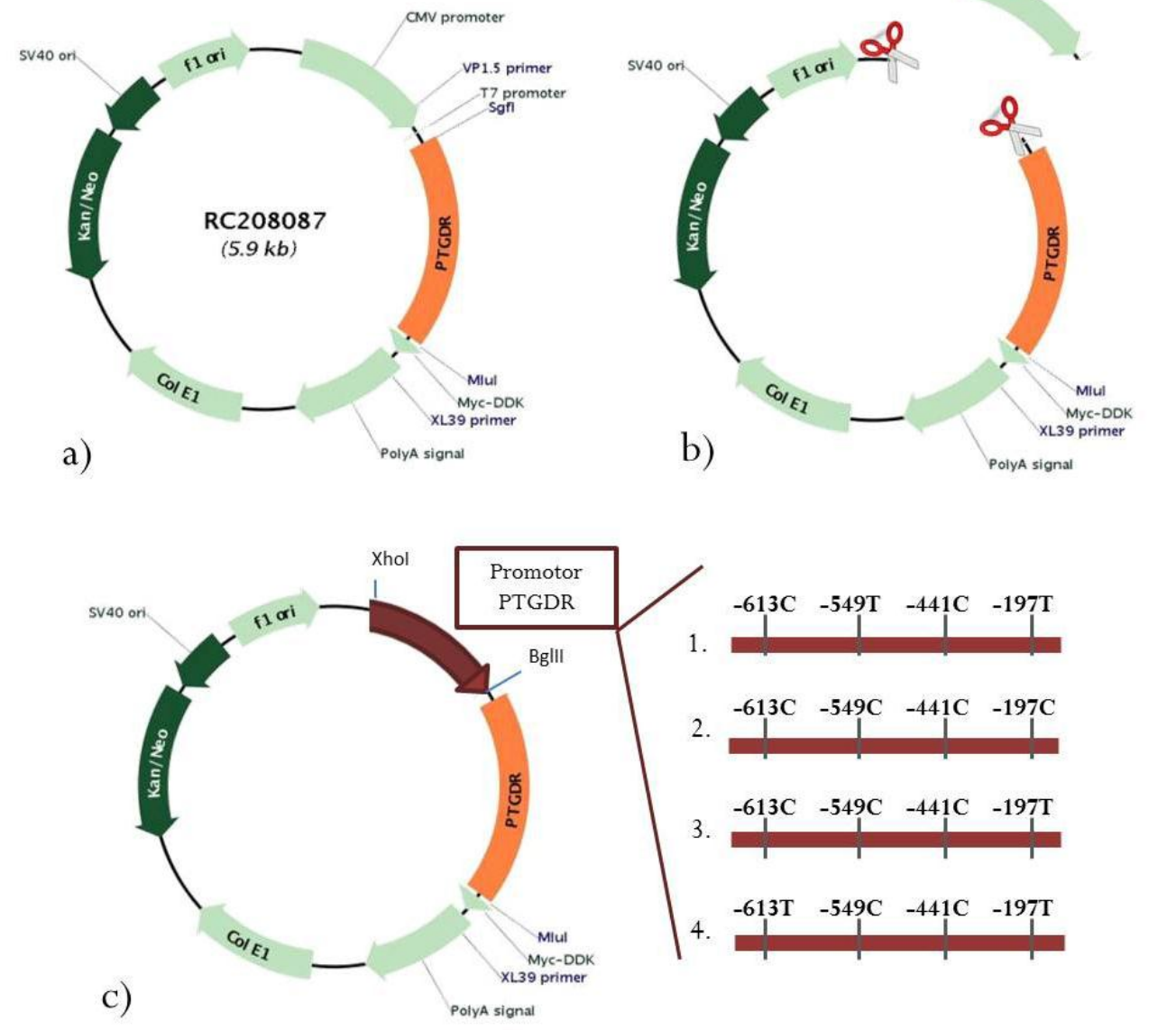

Figura 31: Construcción de vectores de expresión de PTGDR. a) Esquema del vector de partida RC208087, b) Eliminación del promotor fuerte de CMV, c) Clonación de las secuencias polimórficas del promotor de PTGDR. 


\section{Vector pCMV-XL5}

El vector $\mathrm{pCMV-XL5}$ contiene el promotor de CMV pero no presenta ningún gen asociado (Figura 32). Se utilizó como control negativo de transfección en los ensayos de sobreexpresión de PTGDR, ya que se trata del vector de base del anteriormente especificado RC208087. Este tipo de "vector vacío" es el más adecuado para comprobar si la mera presencia del esqueleto plasmídico en la célula modifica su patrón de expresión génica.

\section{$\underline{\text { Vector pUC18 }}$}

El vector pUC18 es un plásmido de alto número de copias, que en este trabajo únicamente se utilizó como vector inocuo, a fin de estandarizar la cantidad de ADN transfectada en todas las condiciones experimentales (Figura 32).

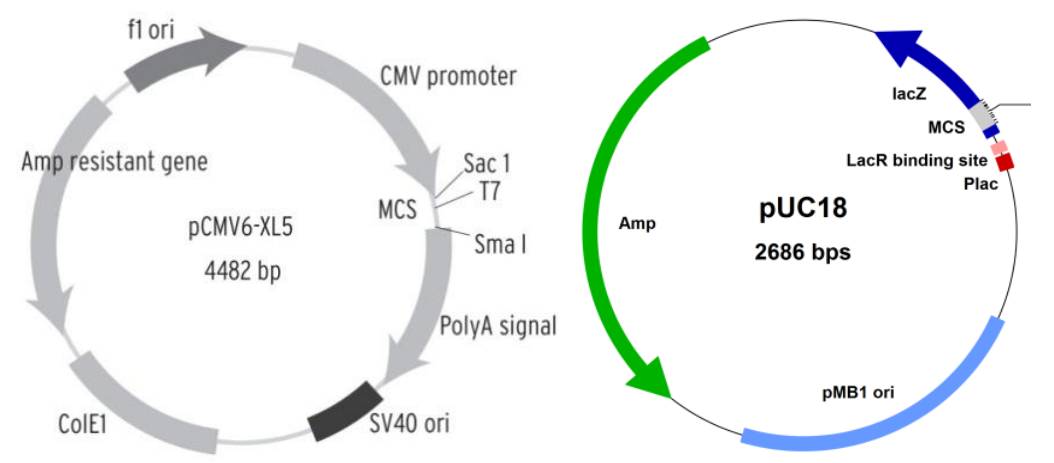

Figura 32: Esquemas de los vectores pCMV6-XL5 y pUC18. 


\subsubsection{Obtención de ADN plasmídico}

\section{- Transformación bacteriana}

La transformación bacteriana con los plásmidos de interés se llevó a cabo sobre células competentes SoloPack Gold (Stratagene, Agilent Technologies, CA, EEUU), que cuentan con una elevada eficiencia de transformación ( $\geq 10 \times 10^{8} \mathrm{cfu} / \mu \mathrm{g}$ pUC18). Cada alícuota de células se transformó con 20-50 ng del ADN plasmídico mediante choque térmico. Para ello, tras incubar en hielo 30 minutos la mezcla de células y ADN plasmídico, se las sometió a un pulso de calor, a $42^{\circ} \mathrm{C}$ durante 60 segundos. Tras esto, se mantuvo a las células en hielo durante 2 minutos $y$, tras añadir $175 \mu$ le medio LB, se incubaron durante 1 hora a $37 \stackrel{\circ}{ } \mathrm{C}$. Finalmente, se plaqueó la mezcla de transformación en placas de LB con el antibiótico adecuado y se dejó incubando a 37ํㅡ hasta el día siguiente.

Una vez se obtuvieron las colonias transformadas, se tomó una colonia única con el extremo de un palillo estéril y se inoculó en 3-5 ml de medio LB con antibiótico, que se incubó a $37^{\circ} \mathrm{C}$ en agitación. De esta manera, se dispone del cultivo preparado para la purificación del plásmido o para elaborar los stocks correspondientes.

\section{- Purificación de plásmidos mediante Maxi-Preps}

Para obtener grandes cantidades de ADN plasmídico, se utilizó el kit comercial QIAGEN Plasmid Maxi kits (Qiagen, Alemania). Como indica el protocolo comercial, se partió de $200 \mu \mathrm{l}$ de un cultivo líquido de bacterias transformadas con el plásmido de interés, que se inocularon en $100 \mathrm{ml}$ de medio selectivo LB para aumentar la cantidad de plásmido final. El método se basa en la lisis alcalina del cultivo bacteriano y la 
posterior selección del ADN plasmídico mediante columnas de intercambio aniónico, bajo condiciones idóneas de $\mathrm{pH}$ y escasa salinidad. Posteriormente, se eliminaron todos los restos de ARN, proteínas, metabolitos y otras impurezas mediante lavados con distintas soluciones de salinidad media. El ADN plasmídico se eluyó mediante la acción de una solución con una elevada concentración de sales, que fueron eliminadas por precipitación del ADN con isopropanol. Tras lavados con etanol, finalmente se obtuvo una concentración elevada (superior a $500 \mathrm{ng} / \mu \mathrm{l}$ ) del plásmido disuelto en agua libre de nucleasas, que se mantuvo a -20ํC hasta su utilización.

\section{- Verificación de los plásmidos clonados}

Es importante asegurar la identificación de los plásmidos a utilizar. Para ello se realizaron digestiones enzimáticas mediante enzimas de restricción y se analizaron los tamaños de los fragmentos obtenidos mediante electroforesis en gel de agarosa al $1 \%$. En el caso de los vectores que portan las cuatro variantes de la fracción de promotor, de forma adicional, se llevó a cabo la secuenciación automática de esos fragmentos (ver apartado 4.3.10).

\section{- Stocks de glicerol}

Se conservaron stocks de glicerol de las distintas cepas bacterianas transformadas con los vectores especificados anteriormente. Para ello, se mezclaron 0,15 $\mathrm{ml}$ de glicerol estéril con 0,85 $\mathrm{ml}$ del cultivo bacteriano en fase logarítmica de crecimiento en crioviales de $2 \mathrm{ml}$. De cada uno de los plásmidos, se guardaron varios stocks. Un cultivo stock o permanente se guardó a -80ํㅡ para conservar las bacterias durante largos períodos de tiempo, y un cultivo semi-stock, como paso intermedio 
entre el cultivo stock permanente y el cultivo de trabajo, se mantuvo mediante congelación a $-20^{\circ} \mathrm{C}$.

\subsubsection{Cultivo celular}

\section{- Línea celular y condiciones basales de cultivo}

En este trabajo se ha utilizado la línea celular A549 de adenocarcinoma de pulmón, que es una línea comercial establecida por la ATCC (American Type Culture Collection, www.atcc.org). Se trata de células humanas de epitelio basal alveolar, obtenidas por primera vez en el año 1972, a partir de muestras de adenocarcinoma de pulmón de un varón caucásico de 58 años. En un pulmón sano, estas células corresponden a las células epiteliales alveolares de tipo II, implicadas en la producción de surfactante, así como en la difusión de agua y electrolitos a través de la superficie del alveolo (217-220). La línea A549 ha sido ampliamente utilizada en el estudio de distintas patologías pulmonares, como la infección por Virus Respiratorio Sincitial (VRS) (221), y en estudios sobre enfermedad pulmonar obstructiva crónica (EPOC) (222), así como en estudios de inflamación alérgica $(223,224)$, y de asma $(225,226)$. Esta línea celular se ha utilizado previamente para el análisis de expresión del gen PTGDR y su asociación con la susceptibilidad al asma (197).

Las células A549, fueron suministradas a nuestro grupo de trabajo por la Dra. MD Odero, desde el Centro de Investigación Médica Aplicada (CIMA) de la Universidad de Navarra. Se han mantenido a $37^{\circ} \mathrm{C}$, en medio RPMI suplementado con $10 \%$ Suero Fetal Bovino (SFB) (Gibco, Thermo Fisher Scientific, MA, EEUU) y antibióticos (Penicilina $10 \mathrm{U} / \mathrm{ml}$ y Estreptomicina $100 \mu \mathrm{g} / \mathrm{ml}$ ), en una atmósfera humidificada y con 
$5 \%$ de $\mathrm{CO}_{2}$. En cultivo in vitro crecen en monocapa (Figura 33) y son células adherentes, que se desarrollan unidas a la base del frasco de cultivo. Se han utilizado frascos de cultivo Roux de $75 \mathrm{~cm}^{2}$ (T-75) estériles, y se ha trabajado en el interior de una cabina de flujo laminar de clase II en condiciones asépticas, para evitar contaminaciones (227).

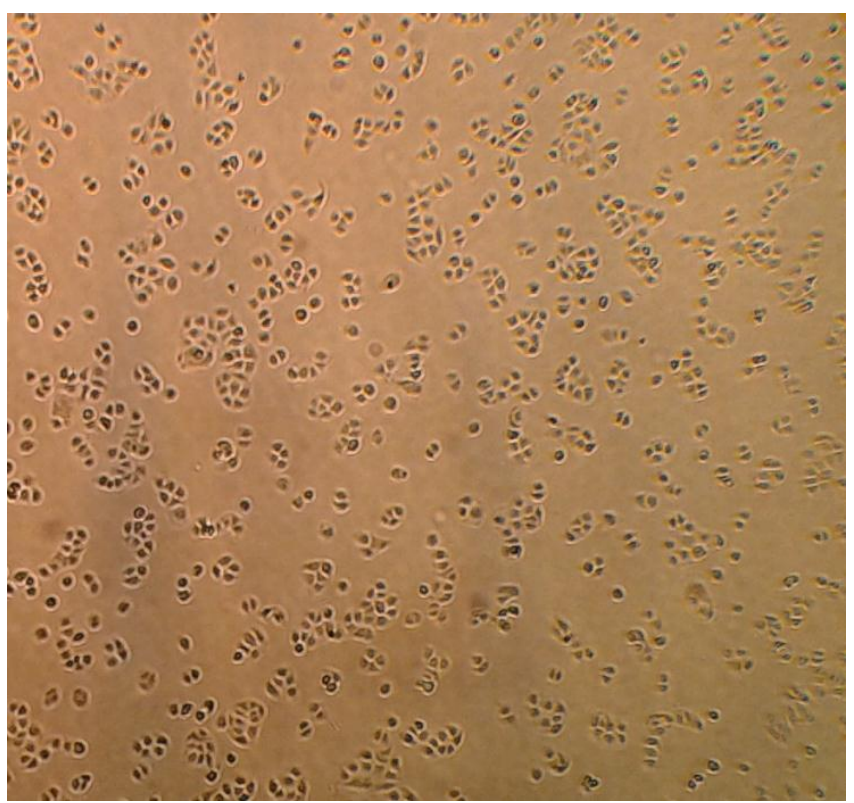

Figura 33. Fotografía de cultivo celular A549. Imagen tomada con el objetivo 40x.

\section{- Técnicas básicas de cultivo celular}

\section{$\underline{\text { Subcultivo de células. Tripsinización y cambio de medio }}$}

La frecuencia con la que se llevó a cabo el subcultivo o pase de células se determinó mediante observación directa al microscopio del cultivo celular, siempre teniendo en cuenta los criterios de densidad celular, envejecimiento del medio de cultivo y el tiempo desde el último pase. Por las características de crecimiento de la línea celular utilizada, esto se correspondió con una frecuencia de pase de 2-3 días, diluyendo el cultivo a una ratio 1:2 o 1:3. 
El primer paso para realizar el subcultivo fue tripsinizar las células para despegarlas de la base del frasco. Para ello se retiró el medio de cultivo existente, se realizó un lavado con PBS y se añadieron $2 \mathrm{ml}$ de solución Tripsina/EDTA (0,25\%/1 $\mathrm{mM}$ ), de manera que toda la superficie estuviera cubierta por dicha solución. A continuación se incubó durante 5-7 minutos a 37으 en el incubador de $\mathrm{CO}_{2}$. Tras observar al microscopio que las células se habían dispersado, se añadió al menos el mismo volumen de medio completo atemperado que de tripsina, a fin de detener la actividad proteolítica de la misma. Con ayuda de una pipeta se homogeneizó la suspensión de células, que fue transferida a un tubo estéril. Este se centrifugó durante 5 minutos a $\geq 235 \times g$ y se eliminó el sobrenadante. El botón celular se resuspendió en $6 \mathrm{ml}$ de medio completo (RPMI con 10\% SFB y antibióticos), de los que $2 \mathrm{ml}$ se transfirieron a un nuevo frasco de cultivo. El cultivo celular se diluyó al añadir $10 \mathrm{ml} \mathrm{de}$ medio completo. Las células subcultivadas se incubaron en las condiciones estándar del cultivo $\left(37^{\circ} \mathrm{C}\right.$ y $5 \%$ de $\left.\mathrm{CO}_{2}\right)$.

\section{Contaje y determinación de la viabilidad celular}

El contaje de células, y la determinación de su viabilidad se realizó mediante tinción celular con la solución de azul de tripano (Thermo Fisher Scientific, MA, EEUU), utilizando una cámara de Neubauer. Para ello, una vez tripsinizadas, se realizó una dilución $1 / 2$ de las células con el colorante, se calculó la media del contaje de los cuatro cuadrantes de las esquinas (de $0,1 \mathrm{~mm}^{3}$ cada uno) de la cámara de recuento, y se estimó la concentración celular de acuerdo con la fórmula:

Células $/ m l=$ recuento medio por cuadrante $\times$ factor de dilució $n \times 10^{4}$ 
El azul tripan, o azul de tripano, es un colorante derivado de la toluidina, que permite evaluar la viabilidad de las células por exclusión de captación. Las células vivas, con membranas íntegras, no permiten la entrada del colorante, mientras que las células muertas, debido a la ruptura de la integridad de la membrana plasmática, sí lo permiten (228). La viabilidad celular se estableció mediante la fórmula:

$$
\% \text { células viables }=\frac{n^{\text {o }} \text { de células no teñidas }}{n^{\text {o }} \text { total de células }} \times 100
$$

\section{Criopreservación}

Una vez tripsinizadas las células, se resuspendieron en $2 \mathrm{ml}$ de SFB. Mediante contaje en cámara Neubauer, se ajustó la concentración a 5-10×10 células/ml en SFB. Se alicuotaron en crioviales de $2 \mathrm{ml}$ a los que se añadieron 1,8 $\mathrm{ml}$ de resuspensión celular, y $200 \mu \mathrm{l}$ de dimetilsulfóxido (DMSO). Tras homogeneizar la mezcla, los crioviales se transfirieron a un contenedor previamente enfriado a 4 으 (StrataCooler Cryo preservation module, Stratagene, Agilent Technologies, CA, EEUU), que permitió la congelación de las células a una velocidad controlada y la mejora de las ratios de supervivencia de las células tras la congelación. El contenedor se transfirió a un ultracongelador de $-80^{\circ} \mathrm{C}$ durante 24 horas. Transcurrido este tiempo, los crioviales se traspasaron a un contenedor de nitrógeno líquido para su almacenamiento indefinido.

\section{Descongelación celular}

La descongelación celular es un proceso que debe realizarse con la mayor rapidez posible para evitar que el contacto con el DMSO merme la viabilidad celular. 
Antes de iniciar la descongelación celular se tomaron $30 \mathrm{ml}$ de medio RPMI en un tubo y se precalentaron a $37^{\circ} \mathrm{C}$ en un baño termostático. Inmediatamente después de sacar el criovial del nitrógeno líquido, y manteniéndolo en hielo, se añadió el medio precalentado con una pipeta Pasteur estéril. De esta forma, a medida que las células se fueron descongelando y traspasando al tubo con el medio atemperado, se diluyó el medio de congelación. Se centrifugó durante 5 minutos a $\geq 370 \times g$. Se resuspendió el pellet en $3 \mathrm{ml}$ de medio, asegurándose de eliminar aglomerados celulares, y se añadió a un frasco pequeño de $25 \mathrm{~cm}^{2}$ (T-25) en el que previamente se habían atemperado otros $2 \mathrm{ml}$ de medio. Al final, las células quedaron resuspendidas en un total de $5 \mathrm{ml}$. Hasta que las células adquirieron la densidad adecuada para su óptimo crecimiento, el medio de cultivo fue RPMI suplementado con $20 \%$ de SFB. Una vez que se alcanzó una cinética de crecimiento adecuada, el cultivo se transfirió a un frasco de cultivo mayor (T-75).

\section{Control de contaminación del cultivo celular por Mycoplasma sp}

Una de las contaminaciones más abundantes en los cultivos celulares es la que se produce por algunas especies de Mycoplasma. Éstas pueden encontrarse en la piel humana, y contaminar los cultivos celulares por manipulaciones poco asépticas o por la utilización de sueros o tripsinas previamente contaminados, provocando alteraciones metabólicas, de la tasa de proliferación y de la capacidad antigénica (229). La contaminación por Mycoplasma puede pasar inadvertida en una observación rutinaria del cultivo, ya que se trata de células procariotas que forman pequeñas colonias no distinguibles fácilmente (230). 
Se realizaron controles de los cultivos celulares mediante análisis de PCR utilizando muestras del sobrenadante celular de cultivos crecidos en ausencia de antibióticos durante varios días para obtener mejor señal. Utilizando cebadores específicos (Tabla 6) se evaluó la contaminación por Mycoplasma mediante la amplificación de una región de $16 \mathrm{~S}$ ARN de ocho especies de Mycoplasma distintas ( $M$. hyorhinis, M. arginini, M. pneumoniae, M. fermentans, M. orale, M. pirum, Acholeplasma laidlawii y Spiroplasma mirum).

Los resultados de la PCR se analizaron mediante electroforesis en gel de agarosa, en el que se observaría una banda de unos 500 pares de bases en caso de contaminación positiva.

A lo largo de la realización de este trabajo, no se detectó contaminación por Mycoplasma en ninguno de los controles realizados.

\section{Microscopía}

Durante todo el proceso experimental, las células se observaron frecuentemente mediante microscopía óptica invertida para comprobar la morfología celular, la tasa de crecimiento, la viabilidad, posibles contaminaciones, etc. Para ello, se utilizó un microscopio invertido AE31, Motic ${ }^{\circledR}$ de campo claro y contraste de fase.

\section{Recolección de células para ensayos moleculares}

Una vez terminado el tiempo de cultivo celular específico de cada ensayo, se recogieron para determinaciones futuras tanto el medio de cultivo en el que habían crecido las células como el extracto celular. El medio de cultivo se recolectó en tubos 
eppendorf o crioviales y, tras una centrifugación de 5 minutos a $\geq 370 \times g$ para eliminar restos de detritus celulares, se mantuvo a -80 ㄷ C hasta su utilización.

Para la recogida de las células se realizó una tripsinización convencional utilizando los volúmenes de tripsina/EDTA $(0.25 \% / 1 \mathrm{mM})$, PBS y medio completo adecuados al tamaño del recipiente de cultivo. El pellet de células generado se resuspendió en la solución adecuada, según los ensayos a realizar posteriormente.

\section{- Tratamiento farmacológico con corticosteroides}

Durante la realización de los ensayos de tratamiento corticoideo, las células se mantuvieron en medio RPMI suplementado con SFB modificado Charcoal Stripped (Gibco, Thermo Fisher Scientific, MA, EEUU) con baja concentración de hormonas. La utilización de este suero minimiza la posible interferencia en el tratamiento derivada de la presencia de hormonas esteroides en el suero fetal bovino convencional.

Se preparó una solución stock de dexametasona (Sigma-Aldrich, MO, EEUU) a una concentración de $2,5 \times 10^{-3} \mathrm{M}$ en etanol absoluto a -80 으 y se alicuotó en tubos eppendorf de 1,5 ml. A partir de este stock, en el momento de su utilización, se realizó una dilución intermedia de $2,5 \times-10^{-5} \mathrm{M}$ en medio RPMI atemperado. De la dilución intermedia se añadió el volumen necesario a las células en cultivo para obtener la concentración final de $2,5 \times 10^{-6} \mathrm{M}$. La solución stock se guardó inmediatamente a -80 ㄷ y las diluciones intermedias se descartaron.

De forma paralela al tratamiento con dexametasona, se replicaron los ensayos con células tratadas con etanol absoluto a una dilución 1/100 (equivalente a la dilución que sufre con la dexametasona) y células sin tratamiento ni aditivos, para obtener los 
controles experimentales necesarios de evaluación de los posibles efectos del vehículo (etanol) sobre el cultivo celular.

Los diferentes tipos de ensayos celulares en los que se midió el efecto del tratamiento con corticoide requirieron la siembra de distinto número de células. Por lo tanto, los volúmenes de medio, corticoide y etanol son específicos para cada uno de ellos (Tabla 8).

Tabla 8: Especificaciones metodológicas de los distintos ensayos.

\begin{tabular}{|lcc|}
\hline & Luciferasa & Expresión génica y citocinas \\
\hline Placas utilizadas & $\mathrm{p}-24$ & $\mathrm{p}-6$ \\
\hline No células sembradas & 50.000 cél./pocillo & 400.000 cél./pocillo \\
\hline Vol. Dexa $2.5 \times 10^{-5} \mathrm{M}$ & $50 \mu \mathrm{l}$ & $200 \mu \mathrm{l}$ \\
\hline Vol. EtOH $1 / 100$ & $50 \mu \mathrm{l}$ & $200 \mu \mathrm{l}$ \\
\hline Vol. final cultivo & $500 \mu \mathrm{l}$ & $2000 \mu \mathrm{l}$ \\
\hline
\end{tabular}

\subsubsection{Transfección transitoria con lípidos catiónicos. Lipofección}

Existen numerosos métodos que permiten la entrada de material genético exógeno en el interior de una célula eucariota. La fórmula elegida para este trabajo ha sido la de la lipofección o transfección mediada por lípidos catiónicos. Esta técnica neutraliza la oposición generada por las cargas negativas, tanto de la membrana plasmática de la célula como de la molécula de ADN, mediante la formación de partículas coloidales con lípidos catiónicos. Estas partículas rodean a la molécula de ADN exógeno y permiten su entrada en la célula mediante la vía endocítica (231). 
Aunque la lipofección tiene un elevado coste económico, proporciona una elevada eficiencia de transfección en cultivos de células adherentes, como es el caso del cultivo de la línea celular A549.

El reactivo que se utilizó en todas los ensayos de transfección fue Lipofectamina 2000 (Invitrogen, Thermo Fisher Scientific, MA, EEUU), que está compuesta por el lípido catiónico 2,3-dioleyloxy-N-[2(sperminecarboxamido)ethyl]N,Ndimethyl-1-propanaminium trifluoroacetate (DOSPA), y el lípido neutral dioleoyl phosphatidylethanolamine (DOPE), en una relación de 3:1 (w/w) (232).

\section{- Procedimiento general}

Tanto en los ensayos de actividad promotora con gen reportero, como en los ensayos de expresión génica y síntesis de citocinas con vectores de sobreexpresión, se trabajaron tres condiciones de ensayo. Por un lado aquellas células que se sometieron al tratamiento con dexametasona, y por otro lado los controles con el vehículo del corticoide (etanol) y los controles sin ningún tratamiento. En todos los casos, se analizaron dos tiempos experimentales, que se establecieron en 12 horas y 36 horas después del inicio de tratamiento. En el caso de las células en las que no se añadió tratamiento, el tiempo comenzó a contar al cambiar el medio de transfección por medio de cultivo completo.

Entre 20-24 horas antes del inicio de la transfección se sembró el número apropiado de células para cada experimento. Para establecer el número óptimo de células a sembrar, de forma preliminar se realizaron pruebas con distintas densidades celulares, eligiendo aquella condición que proporcionó una confluencia entre un $60 \%$ y un $80 \%$ en el momento de la transfección. 
La siembra se realizó en medio suplementado con SFB Charcoal Stripped, para minimizar el efecto de los corticoides contenidos en el suero convencional, y sin la presencia de antibióticos, ya que éstos pueden mermar la eficiencia del proceso debido a la toxicidad celular que generan en combinación con los reactivos de transfección. Para ello, y como se ha explicado anteriormente, se tripsinizaron las células en cultivo y se contaron en una cámara Neubauer tiñendo con azul de tripano (Tabla 9).

Al día siguiente de la siembra de células, se realizó una primera mezcla del ADN plasmídico con medio Opti-MEM ${ }^{\circledR}$ I (Gibco, Thermo Fisher Scientific, MA, EEUU), incubándose durante 5 minutos. Durante este tiempo se preparó la mezcla del reactivo Lipofectamine ${ }^{\circledR} 2000$ (Invitrogen, Thermo Fisher Scientific, MA, EEUU) con medio Opti$\mathrm{MEM}^{\circledR} \mathrm{I}$, y se incubó durante 5 minutos protegido de la luz. Posteriormente, se juntó la mezcla del ADN plasmídico con la mezcla de la lipofectamina, y se mantuvo durante 20-30 minutos a temperatura ambiente y protegido de la luz, para permitir la formación de los complejos ADN-liposoma.

Se añadió la mezcla de transfección a las células sembradas previa retirada del medio de cultivo, y se agregó un volumen idéntico de medio Opti-MEM ${ }^{\circledR}$ I para asegurar que el cultivo celular quedase completamente cubierto.

Se mantuvo a las células con la mezcla de transfección durante 4-6 horas en el incubador de $\mathrm{CO}_{2}$, a 37으. Tras esta incubación, se retiró la mezcla de transfección y se añadió medio RPMI con 10\% de SFB Charcoal Stripped y con el tratamiento indicado en cada caso. 
Tabla 9: Especificaciones para la lipofección en los diferentes ensayos.

\begin{tabular}{|c|c|c|}
\hline & Luciferasa & Expresión génica y citocinas \\
\hline Placas utilizadas & $p-24$ & $p-6$ \\
\hline Tamaño pocillo & $1,88 \mathrm{~cm}^{2}$ & $9,40 \mathrm{~cm}^{2}$ \\
\hline № células sembradas & 50.000 células/pocillo & 400.000 células/pocillo \\
\hline \multirow{2}{*}{ Vectores de transfección } & 500 ng Inserto-luc/ pocillo & $1 \mu \mathrm{g}$ Inserto-PTGDR/ pocillo \\
\hline & 10 ng Renilla/pocillo & 1,5 $\mu \mathrm{g}$ pUC18/pocillo \\
\hline Total ADN transfectado & $510 \mathrm{ng} /$ pocillo & 2,5 $\mu \mathrm{g} /$ pocillo \\
\hline Volumen lipofectamina & $1 \mu \mathrm{l} /$ pocillo & $5 \mu \mathrm{l} /$ pocillo \\
\hline $\begin{array}{l}\text { Volumen total de la } \\
\text { mezcla transfección }\end{array}$ & $100 \mu \mathrm{l} /$ pocillo & $500 \mu \mathrm{l} /$ pocillo \\
\hline
\end{tabular}

\subsubsection{Ensayos de actividad promotora con gen reportero}

\section{- Transfección con vector de luciferasa}

Los ensayos de transfección con los vectores portadores del gen reportero de la luciferasa se realizaron en placas de 24 pocillos, sembrando un total de 50.000 células por pocillo (Tabla 9). Siguiendo las recomendaciones del fabricante, se transfectó una cantidad final de $510 \mathrm{ng}$ de ADN por cada pocillo, en medio Opti-MEM ${ }^{\circledR}$ I hasta $50 \mu$ l. De éstos, 500 ng correspondieron al vector de luciferasa de luciérnaga (Luc) más el inserto correspondiente a la secuencia del promotor de PTGDR, y $10 \mathrm{ng}$ correspondieron al vector portador de la luciferasa de Renilla. El volumen de lipofectamina por pocillo fue de $1 \mu$ l diluido en $49 \mu$ l de Opti-MEM $^{\circledR}$ I. Por cada una de las condiciones se realizaron triplicados intra-ensayo, utilizando tres pocillos para cada 
mezcla de ADN (Figura 34), debido al riesgo de error al manejar volúmenes y número de células tan pequeños.

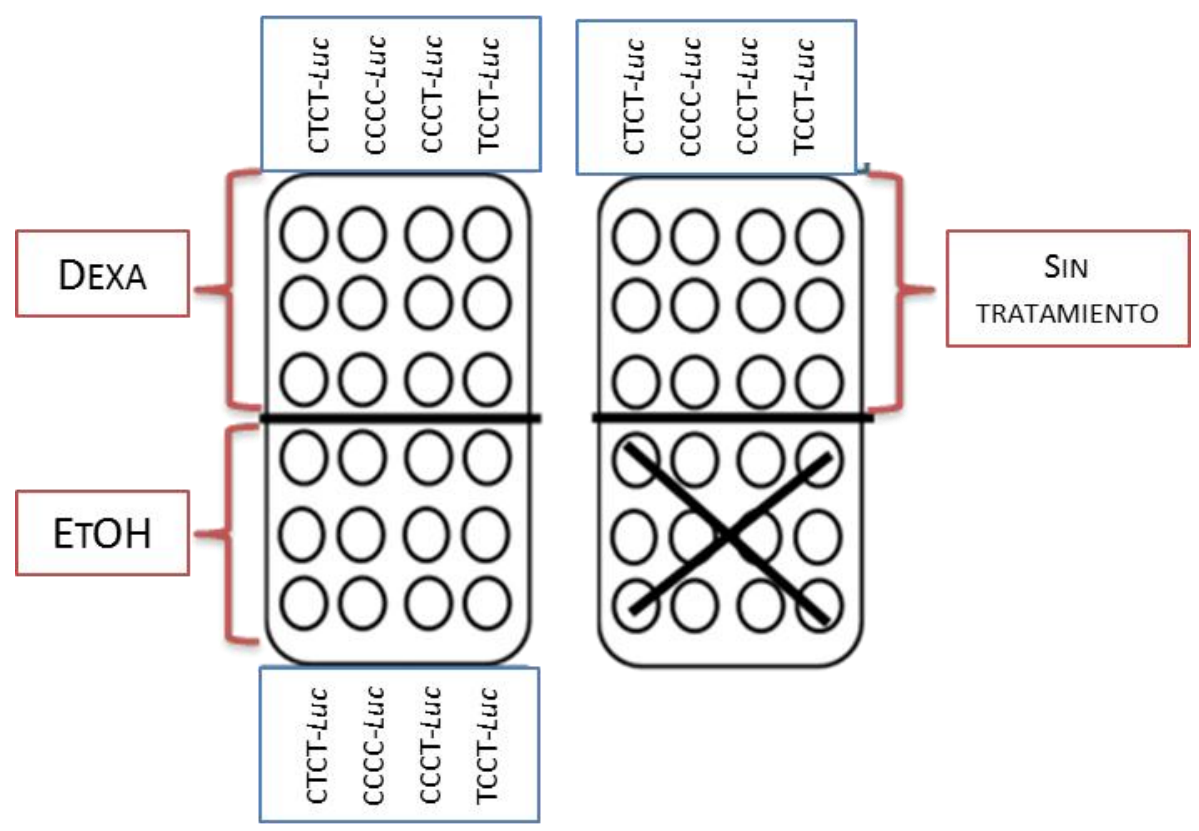

Figura 34: Planificación del ensayo para medir la actividad promotora con luciferasa.

- Análisis de la actividad promotora mediante gen reportero

En el análisis de la actividad promotora mediante gen reportero, se utilizó el sistema Dual-Luciferase ${ }^{\circledR}$ Reporter Assay System (Promega, WI, EEUU). Este sistema se basa en la medición de las actividades de las luciferasa de luciérnaga y Renilla de forma secuencial, en la misma muestra, utilizando sustratos diferentes. El primer reactivo añadido Luciferase Assay Reagent II (LAR II), contiene luciferina de escarabajo que actúa como sustrato de la luciferasa de luciérnaga. Esta enzima, que requiere la presencia de ATP, $\mathrm{O}_{2}$ y $\mathrm{Mg}^{2+}$, cataliza la oxidación de la luciferina a oxiluciferina con la producción de $\mathrm{AMP}, \mathrm{CO}_{2}$ y la emisión de luz verde a 560 nm (Figura 35). 


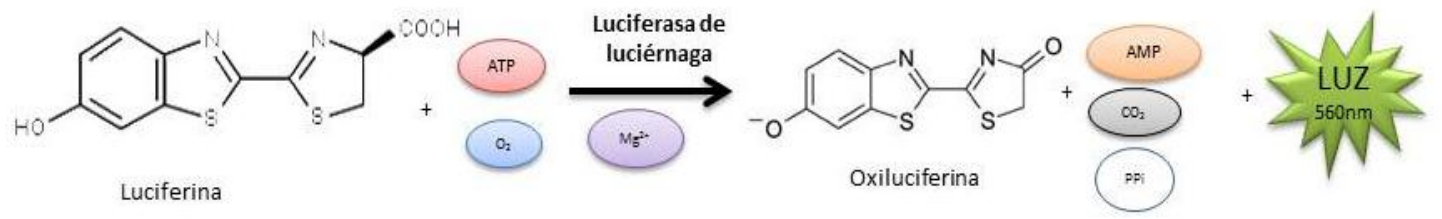

Figura 35: Reacción química llevada a cabo por la luciferasa de luciérnaga.

Cuando la reacción de luciferasa de luciérnaga ha terminado, y tras recoger la emisión de luz producida, se añade el reactivo Stop \& Glo $(S \& G)$. Con este reactivo se detiene la reacción anterior, y se añade el siguiente sustrato, la coelenterazina. La luciferasa de Renilla, en presencia de $\mathrm{O}_{2}$, cataliza la conversión de coelenterazina a coelenteramida, desprendiéndose $\mathrm{CO}_{2}$, y emitiendo luz azul con una longitud de onda de $482 \mathrm{~nm}$ (Figura 36).
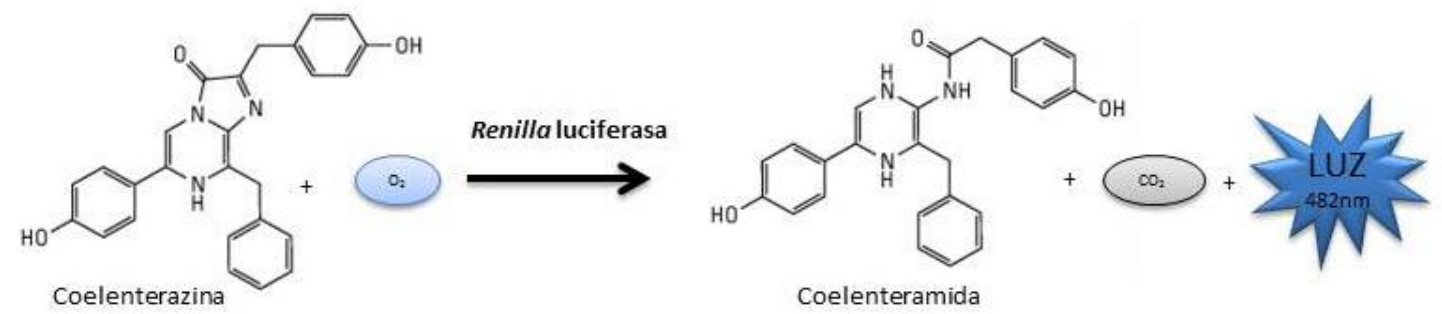

Figura 36: Reacción química llevada a cabo por la Renilla luciferasa.

Una vez finalizado el tiempo de tratamiento establecido, 12 o 36 horas, se recogieron las células sembradas y se analizó la actividad promotora. Para ello, se retiró el medio de cultivo $y$, tras un lavado con PBS, se realizó una lisis pasiva 
añadiendo $100 \mu \mathrm{l}$ de solución de lisis $1 X$ (Passive Lysis Buffer) a cada pocillo. Se dejó incubando durante 15 minutos a temperatura ambiente hasta que la lisis celular fue completa. Las muestras se mantuvieron a $-80^{\circ} \mathrm{C}$ hasta la realización del análisis.

Previamente a la lectura de la luciferasa, se prepararon los reactivos necesarios. Para cada pocillo se utilizaron $50 \mu \mathrm{l}$ del reactivo $L A R I l$ y otros $50 \mu \mathrm{l}$ del reactivo $S \& G$ (diluido hasta $1 \mathrm{X}$ con su propia solución de dilución). Se utilizaron tubos adecuados para introducir en el luminómetro el volumen necesario de cada reactivo, dependiendo de las muestras a analizar. Una vez descongeladas las muestras, y tras centrifugarlas para evitar restos celulares, se cargaron en una placa de 96 pocillos $20 \mu \mathrm{l}$ de cada muestra, y se introdujo en el luminómetro FLUOstar OPTIMA Microplate Reader (BMG LABTECH, Alemania). Este analizador se encarga de ir suministrando el volumen necesario de cada reactivo y de medir las señales luminosas producidas por cada muestra (Tabla 10).

Tabla 10. Programa utilizado para el ensayo de luciferasa en el luminómetro.

\begin{tabular}{|lll|}
\hline & & Tiempo \\
\hline Paso 1 & Adición de reactivo LARII al lisado celular & 3 segundos \\
\hline Paso 2 & Cuantificación de la actividad luciferasa de luciérnaga & 12 segundos \\
\hline Paso 3 & Adición del reactivo S\&G & 3 segundos \\
\hline Paso 4 & Cuantificación de la actividad Renilla luciferasa & 12 segundos \\
\hline Tiempo total requerido para cada muestra & 30 segundos \\
\hline
\end{tabular}

Los datos de los ensayos de luciferasa se expresaron como la ratio:

Unidades relativas de luciferasa $(\boldsymbol{U} \boldsymbol{R} \boldsymbol{L})=\frac{\text { Actividad luciferasa de luciérnaga }}{\text { Actividad Renilla luciferasa }}$ 
Una vez obtenido este valor de URL, se calculó la media y la desviación estándar de los pocillos correspondientes a los tres replicados intra-ensayo de cada mezcla de ADN.

Como ya se ha comentado anteriormente, en cada experimento se testó la acción del tratamiento con dexametasona, del tratamiento con el vehículo etanol y la actividad en condiciones de no tratamiento, de la secuencia promotora de PTGDR con las cuatro combinaciones polimórficas, CTCT, CCCC, CCCT y TCCT (-613, -549, -441, 197). Cada experimento completo se repitió por triplicado, y se realizaron dos tiempos experimentales: 12 horas y 36 horas.

\subsubsection{Ensayos de expresión génica con vectores de expresión}

\section{- Transfección con vectores de expresión}

En el caso de los ensayos para determinar el nivel de expresión de PTGDR en función de los polimorfismos presentes en la región promotora, se utilizaron placas de 6 pocillos y se sembraron 400.000 células por pocillo (Figura 37). Se añadió a cada pocillo $1 \mu \mathrm{g}$ de los vectores generados portadores del inserto con la secuencia del promotor de PTGDR, más el ADNc del gen. Para este tamaño de placa, el fabricante recomienda transfectar con una cantidad total de $2,5 \mu \mathrm{g}$ de $A D N$, por lo que se añadieron a cada pocillo $1,5 \mu \mathrm{g}$ del vector inocuo pUC18, junto con Opti-MEM ${ }^{\circledR}$ I hasta un volumen de $250 \mu \mathrm{l} /$ pocillo. Se sembró un pocillo con células transfectadas únicamente con $2,5 \mu \mathrm{g}$ del vector pUC18 para comprobar si el esqueleto pCMV-XL5 tenía algún efecto. Otro de los pocillos se destinó a células transfectadas con el vector vacío PCMV-XL5 que serviría como control o línea base. 
Se utilizaron $5 \mu \mathrm{l}$ de lipofectamina para cada pocillo disuelta en un volumen total de $250 \mu \mathrm{l}$ de Opti-MEM $^{\circledR} \mathrm{I}$, haciendo un total de mezcla de transfección de $500 \mu \mathrm{l}$ por pocillo. En este caso, no se realizan triplicados intra-ensayo.

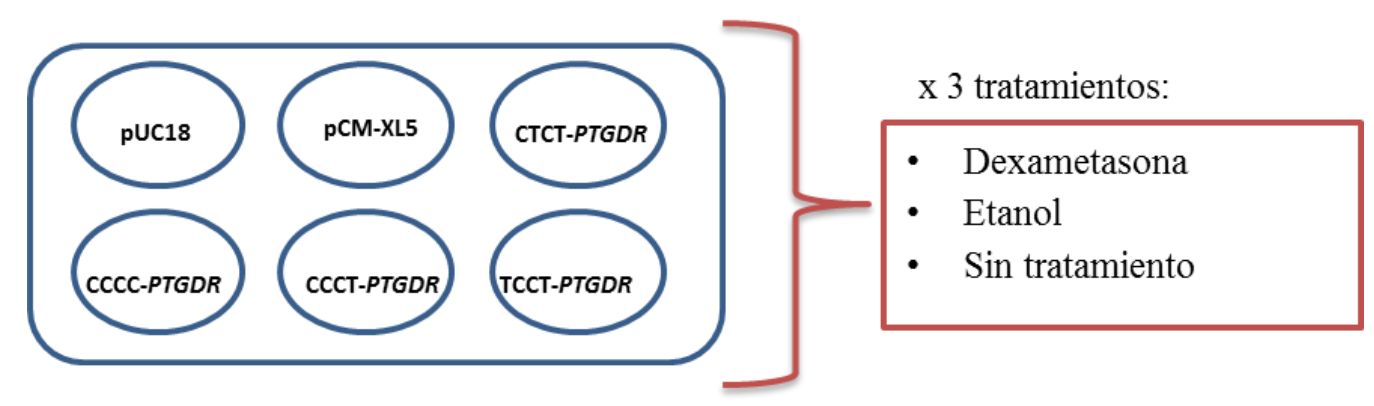

Figura 37: Planificación del ensayo para medir la expresión génica con vectores de expresión.

\section{- Análisis del nivel de expresión}

Una vez finalizado el tiempo de incubación con el tratamiento, se procedió a la recolección de las células sembradas, con el fin de extraer el ARN y llevar a cabo el análisis de expresión por PCR a tiempo real.

Se retiró el sobrenadante celular y se guardó a -80 ํ C tras centrifugarlo durante 15 minutos a $1000 \mathrm{rpm}$ y 4 으. Este sobrenadante se utilizó para el análisis de las citocinas secretadas por las células.

Una vez reservado el medio de cultivo, se lavaron las células con PBS y se recogieron mediante tripsinización con $2 \mathrm{ml}$ de una dilución de tripsina al 25\% en PBS. El pellet de células que se recogió, tras un lavado con PBS, se resuspendió en $350 \mu \mathrm{l}$ de la solución de lisis del kit de extracción de ARN, y se mantuvo a $-80^{\circ} \mathrm{C}$ hasta su procesamiento. Finalmente, se retrotranscribió a ADNc y se procedió al análisis mediante PCR cuantitativa. En cada experimento se testó la acción del tratamiento con 
dexametasona, del tratamiento con el vehículo etanol y la actividad en condiciones de no tratamiento de la secuencia promotora de PTGDR con las cuatro combinaciones polimórficas, CTCT, CCCC, CCCT y TCCT $(-613,-549,-441,-197)$. Cada experimento completo se repitió por duplicado, y se realizaron dos tiempos experimentales: 12 horas y 36 horas.

\subsubsection{Ensayos de expresión de citocinas en cultivo celular}

El sistema Bio-Plex 200 (Bio-Rad, CA, EEUU) para la detección de citocinas en suspensión se basa en reacciones inmunológicas tipo sándwich y en la tecnología Lumine $^{\circledast} \mathrm{XMAP}^{\circledR}$ de citometría de flujo $(233,234)$. En una primera etapa del procedimiento, las moléculas de citocinas son reconocidas por anticuerpos específicos, unidos covalentemente a esferas de poliestireno magnetizadas y codificadas mediante color. En una segunda etapa, un segundo anticuerpo, biotinilado y específico frente a un epítopo diferente, se une a la molécula de citocina conformándose la estructura de sándwich alrededor de ella. Esta formación es reconocida mediante la adición de un conjugado de estreptavidina-ficoeritrina que se une a los anticuerpos biotinilados (235).

Mediante la formación de un flujo uniforme, las esferas pasan de una en una por un doble laser. Un láser clasifica la esfera específica mediante la excitación de su color, determinando de qué citocina se trata, y otro láser se utiliza para excitar la ficoeritrina (Figura 38). De este modo, se produce una doble discriminación de cada complejo sándwich. 


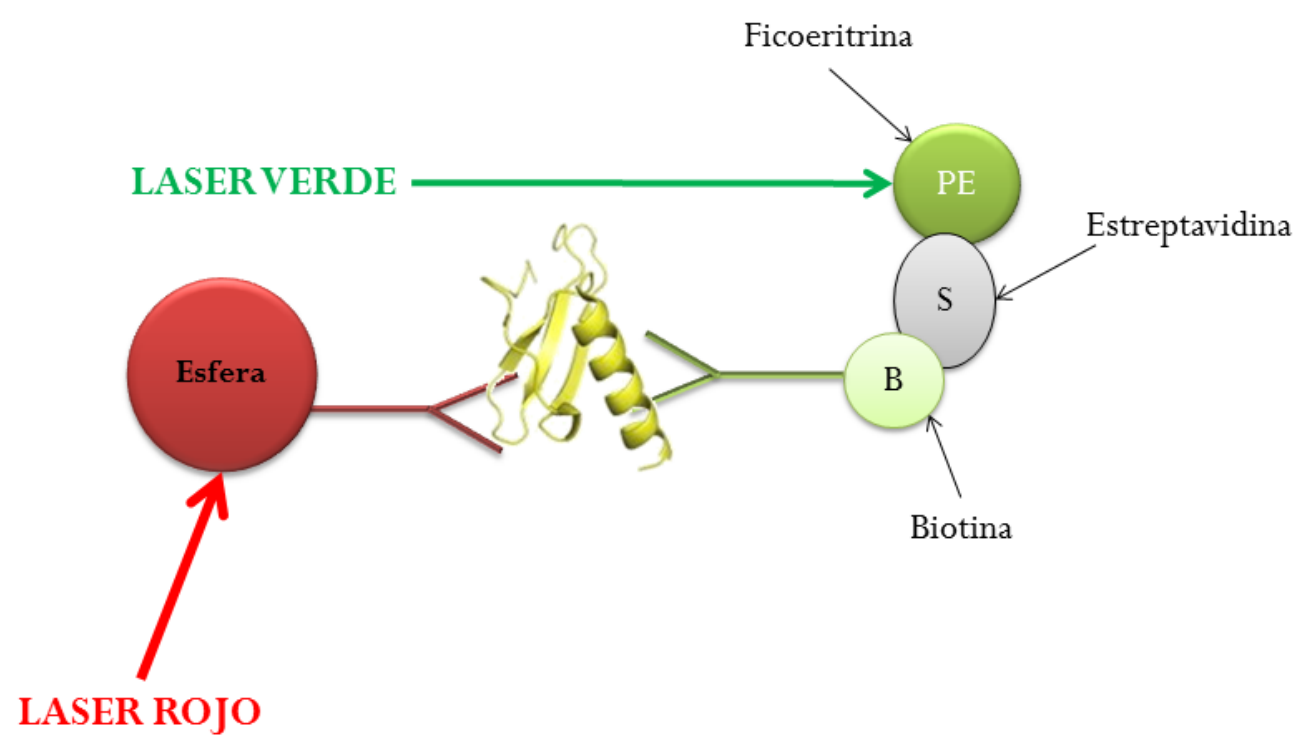

Figura 38: Sistema de reconocimiento de citocinas mediante conjugación con anticuerpos y sistema de doble láser.

\section{- Procedimiento general}

Para el análisis de las citocinas producidas por las células transfectadas con los vectores de expresión, se utilizó el kit Bio-Plex Pro $^{\text {TM }}$ Human Cytokine standard 27-plex, Group I (Bio-Rad, CA, EEUU), mediante el que se cuantifican las citocinas que se detallan en la tabla 11.

La curva de calibración del ensayo se realizó utilizando los estándares del kit resuspendidos en medio de cultivo RPMI más $10 \%$ de SFB Charcoal Stripped para que la matriz fuera igual que en las muestras problema. La curva final se compone de 8 estándares con una relación de 1:4 entre ellos. El blanco también se realizó con medio RPMI con SFB Charcoal Stripped. 
Tabla 11: Panel de citocinas detectadas en el ensayo.

\begin{tabular}{|c|c|c|c|}
\hline \multicolumn{4}{|c|}{$\begin{array}{r}\text { Citocinas detectadas por el kit "Bio-Plex Pro " } \\
\text { standard 27-plex, Group I" }\end{array}$} \\
\hline IL-1 $1 \beta$ & IL-8 & Basic FGF & MIP-1 $\beta$ \\
\hline IL-1ra & IL-9 & G-CSF & PDGF-B \\
\hline IL-2 & IL-10 & GM-CSF & RANTES \\
\hline IL-4 & IL-12p70 & IFN- $\nu$ & TNF- $\alpha$ \\
\hline IL-5 & IL-15 & IP-10 & VEGF \\
\hline IL-6 & IL-17 & MCP-1 & \\
\hline IL-7 & Eotaxina & MIP-1 $1 \alpha$ & \\
\hline
\end{tabular}

Las muestras utilizadas corresponden a los medios de cultivo de las células transfectadas con los vectores de expresión. Se analizaron las citocinas de un replicado completo, que comprende las células sometidas a tratamiento con dexametasona a una concentración de $2,5 \times 10^{-6} \mathrm{M}$, las células sometidas a tratamiento con etanol, y las células sin ningún tratamiento, y a los dos tiempos experimentales realizados (12 horas y 36 horas).

Siguiendo las instrucciones del fabricante, se añadieron $50 \mu \mathrm{l}$ de cada uno de los estándares y de cada una de las muestras, en la placa de lectura en la que previamente se habían añadido $50 \mu \mathrm{l}$ de las esferas a cada pocillo. Tanto las muestras, como los estándares, como el blanco se analizaron por duplicado, por lo que se utilizaron dos pocillos para cada uno.

Las muestras se incubaron durante 30 minutos en agitación junto con las bolas conjugadas con los anticuerpos específicos. Tras este tiempo, y tras realizar tres lavados para eliminar el exceso de esferas, se añadieron $25 \mu \mathrm{l}$ del segundo anticuerpo biotinilado a cada pocillo y se dejó incubar otros 30 minutos en agitación. Se realizaron 
tres lavados para eliminar el exceso, y se añadió el reactivo estreptavidina/ficoeritrina (S/PE), $50 \mu \mathrm{l} /$ pocillo, incubándose 10 minutos en agitación. Por último, y tras lavar de nuevo la placa, se resuspendieron las esferas, que en este punto ya tenían unida la molécula de citocina y el segundo anticuerpo biotinilado y conjugado con S/PE, en 125 $\mu \mathrm{l}$ del Assay Buffer del kit para realizar la lectura en el analizador.

\section{- Análisis de los resultados generados}

El análisis de los resultados obtenidos en el ensayo de expresión de citocinas se realizó mediante el software informático Bio-Plex Manager ${ }^{\mathrm{TM}} 5.0$ (Bio-Rad, CA, EEUU). Este software realiza una curva estándar de cada una de las citocinas analizadas y, a través de un modelo de regresión logística, reporta las concentraciones de cada una de las citocinas de cada muestra a partir de la fluorescencia medida.

Como se ha explicado anteriormente, tanto las muestras como los estándares se midieron por duplicado. La concentración final de cada citocina se calculó a través de la realización de la media de los dos duplicados.

\subsection{Modelo animal}

\subsubsection{Desarrollo de un modelo animal de alergia/asma respiratoria}

Para el desarrollo del modelo animal de asma respiratoria se optó por la línea múrida Balb/c, frecuentemente utilizada en estudios inmunológicos, por la inducción de respuesta de linfocitos Th2 ante la inflamación pulmonar (236). 
Los animales fueron suministrados por Charles River Laboratories, y se manipularon en el Servicio de Experimentación Animal de la Universidad de Salamanca, cumpliendo la legislación vigente contemplada en la normativa europea (2010/63) y española (Real Decreto 53/2013 de 1 de febrero). Todos los protocolos empleados fueron aprobados por el Comité de Bioética de la Universidad de Salamanca.

Se utilizaron hembras de ratón Balb/c de 6 semanas de edad, libres de patógenos, que se mantuvieron en una atmósfera de aire filtrado con acceso libre a agua y comida durante toda la duración de los ensayos. Antes de iniciar el procedimiento experimental, los ratones permanecieron en el animalario durante un periodo de aclimatación de 7 días.

\subsubsection{Procedimiento general}

Para cada experimento se partió de un total de 12 animales. De forma inicial se dividieron en dos grupos de 6 ratones cada uno. Un grupo fue sensibilizado con ovalbúmina (grupo asmático), y otro grupo no (grupo control). La sensibilización con ovalbúmina (OVA) (Sigma-Aldrich, Alemania) se llevó a cabo mediante inyección intraperitoneal (IP) de una mezcla de $20 \mu \mathrm{g}$ de OVA más 2 mg de hidróxido de aluminio (Sigma-Aldrich, Alemania) en un volumen de 0,2 ml de PBS por ratón. A cada ratón del grupo control se les administraron $2 \mathrm{mg}$ de hidróxido de aluminio $\left(\mathrm{Al}(\mathrm{OH})_{3}\right)$ en $0,2 \mathrm{ml}$ de PBS.

Una vez acabada la fase de sensibilización se llevó a cabo la fase de provocación nasal con OVA para provocar la respuesta asmática, y tratamiento con dexametasona. 
Para ello, de forma preliminar, tanto el grupo OVA como el grupo control se dividieron en dos subgrupos. El primer subgrupo de cada grupo recibió tratamiento con dexametasona y el segundo subgrupo no. De esta forma, los ratones quedaron repartidos en cuatro grupos (Figura 39):

- Grupo control sin tratamiento

- Grupo control con tratamiento

- Grupo asmático sin tratamiento

- Grupo asmático con tratamiento

El tratamiento con dexametasona se llevó a cabo una hora antes de las sensibilizaciones nasales, mediante la administración de dexametasona (dexa) (SigmaAldrich, Alemania) vía intraperitoneal a una concentración de 0,2 $\mathrm{mg} / \mathrm{kg}$ en un volumen total de $0,2 \mathrm{ml}$. Los ratones que no recibieron tratamiento con dexametasona recibieron 0,2 $\mathrm{ml}$ de PBS también por vía intraperitoneal.

Al grupo sensibilizado con ovalbúmina se le realizaron provocaciones con OVA $0,1 \%$ en PBS, con un volumen total de $50 \mu \mathrm{l}$, por vía intranasal (IN). A los ratones del grupo control se les suministraron $50 \mu \mathrm{l}$ de PBS también por vía intranasal. Las provocaciones intranasales se ejecutaron con los animales anestesiados con una mezcla de $75 \mathrm{mg} / \mathrm{kg}$ de clorhidrato de ketamina (Imalgene $1000^{\circledR}$, Merial, Francia) más

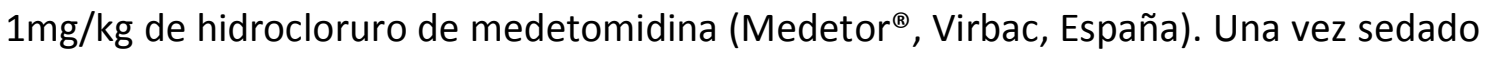
el animal, colocado en posición vertical y con la cabeza ligeramente levantada para evitar la obstrucción de las vía respiratorias, se dejó caer gota a gota la solución de OVA (o PBS) sobre la nariz, consiguiendo la inoculación gracias al propio proceso inspiratorio del ratón. 


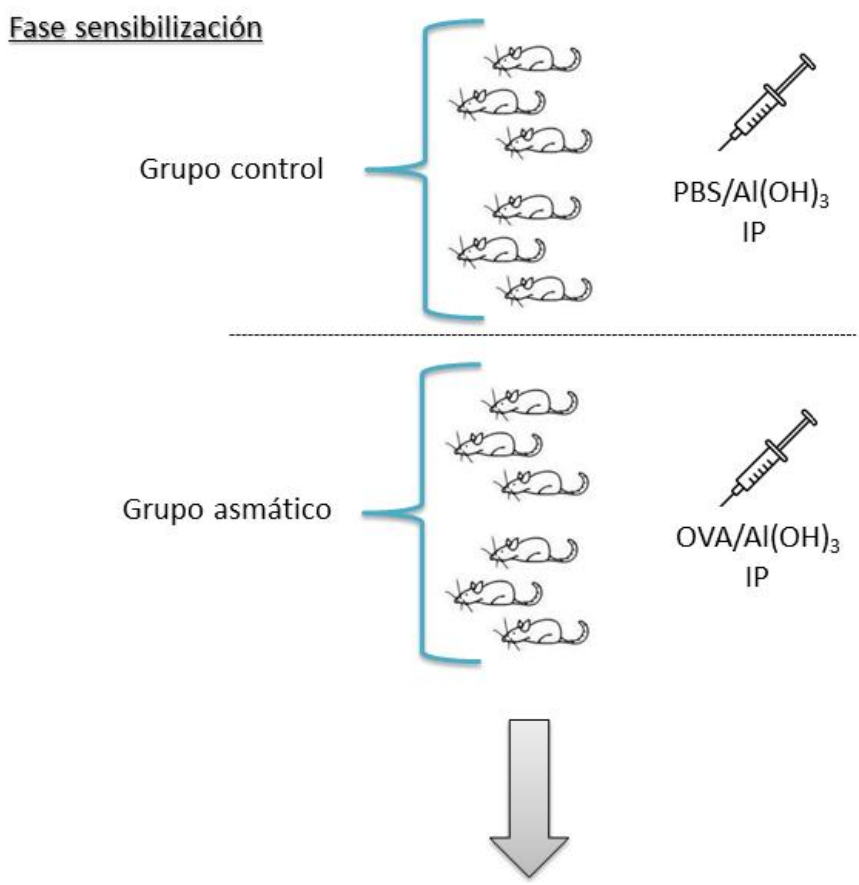

Fase provocación y tratamiento

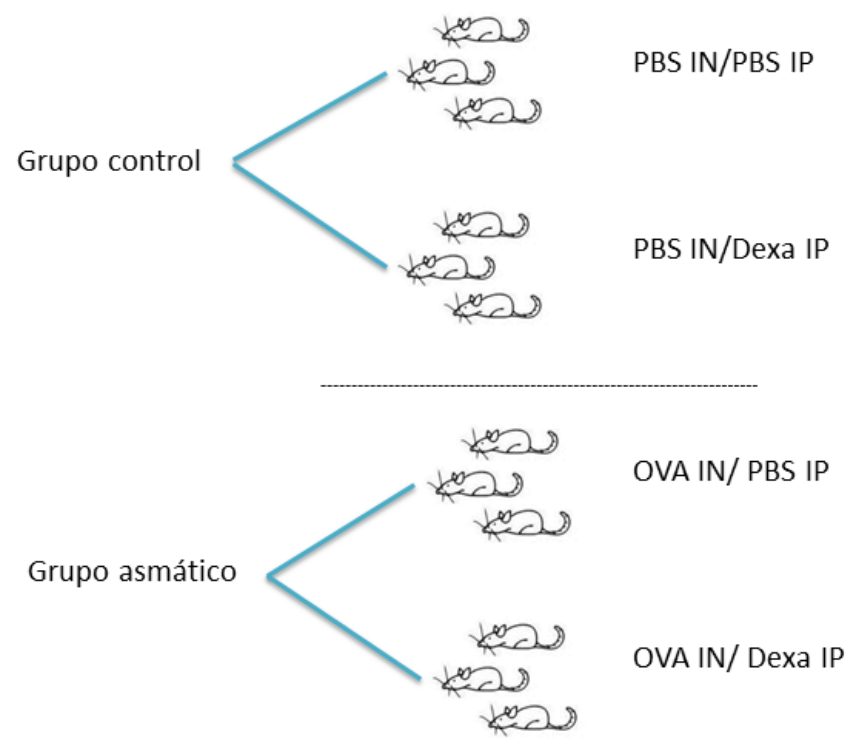

Figura 39: Grupos de tratamiento en el modelo experimental múrido de asma alérgica.

Una vez finalizado el tiempo de tratamiento establecido, tras 48 horas desde la última provocación nasal se llevó a cabo el sacrificio del animal y la recogida de tejido pulmonar, que se mantuvo a $-80^{\circ} \mathrm{C}$ hasta su procesamiento. 


\subsubsection{Modelo crónico de asma alérgica en ratón}

El modelo crónico de asma alérgica en ratón tuvo una duración total de 100 días. El día 0 se procedió a la sensibilización de los ratones del grupo asmático con OVA, y a la administración de PBS al grupo control. El día 7 se repitió el proceso de sensibilización, concluyendo con esta fase.

El día 13 desde el inicio del experimento se realizó la primera inyección con dexametasona a los ratones con tratamiento, y con PBS a los ratones sin tratamiento, pero no se realizó la provocación con OVA hasta el día 14. Como se ha descrito en el procedimiento general, una hora antes de la provocación alérgica se procedió a la inyección de la dexametasona o PBS vía parenteral. Pasado este tiempo y con el animal anestesiado se procedió a la provocación con OVA (o PBS) por vía intranasal. Este procedimiento se repitió tres veces a la semana durante 12 semanas. El sacrificio de los ratones se realizó al 100 día del inicio del experimento.

\subsection{Análisis estadístico de los datos.}

El análisis estadístico se ha realizado utilizando el paquete estadístico SPSS 21.0 (IBM, IL, EEUU). Las pruebas estadísticas que se han realizado con este programa son:

- Medidas de Tendencia Central. dependiendo de las características de las variables se utilizó como medida de tendencia central la media o la mediana.

- Medidas de Dispersión. Las medidas de dispersión que se han utilizado han sido la desviación estándar y/o el rango intercuartílico, en función de las características de las variables. 
- Pruebas de Normalidad. Para evaluar la normalidad de los conjuntos de datos se han realizado el test de Kolmogorov-Smirnov y el test de ShapiroWilk.

- Test de Levene. Prueba estadística utilizada para evaluar la igualdad de varianzas para un variable determinada entre dos o más grupos.

- Prueba de Kruskal-Wallis. Método no paramétrico para comparación de las medias de tres o más grupos que no cumplen homogeneidad de varianzas.

- Prueba de ANOVA. Método paramétrico para comparación de las medias de tres o más grupos que sí cumplen la homogeneidad de varianzas.

- Test de Bonferroni y Test de Tamhane. Pruebas de comparaciones múltiples para concretar las diferencias encontradas entre las medias de tres o más grupos.

- Test de Wilcoxon. Método no paramétrico para comparar la media de dos muestras relacionadas y determinar si existen diferencias entre ellas.

- Test de t-Student. Método paramétrico para comparar la media de dos muestras relacionadas y determinar si existen diferencias entre ellas.

- Estudio del Poder Esatdístico. Representa la capacidad de un test para detectar como estadísticamente significativas diferencias o asociaciones de una magnitud determinada. Esta herramienta permite calcular el tamaño de las poblaciones necesario para detectar diferencias estadísticamente significativas entre ellas. El poder estadístico se calculó utilizando la herramienta informática disponible en www.dssresearch.com. 


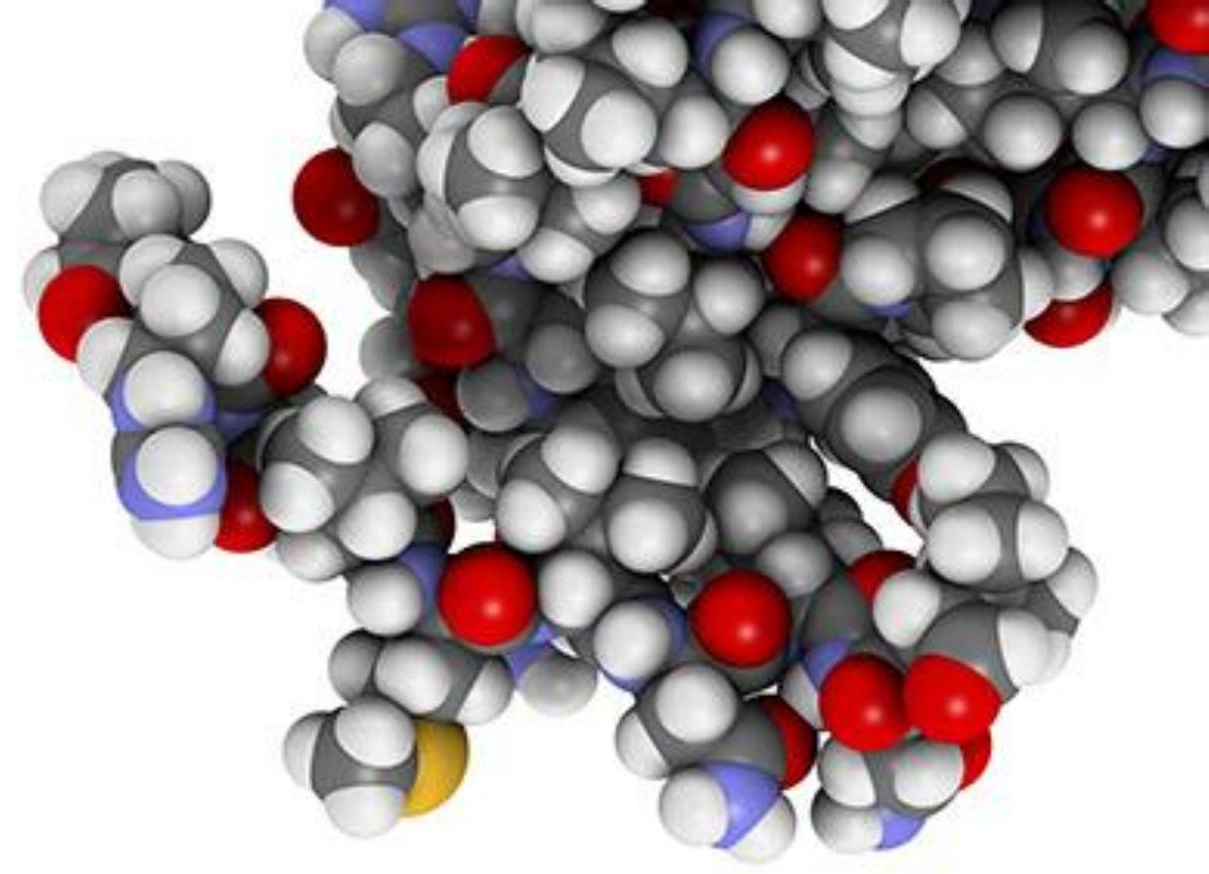

RESVLTAD@S 



\section{RESULTADOS}

5.1. Desarrollo de un modelo de tratamiento con dexametasona en la línea celular pulmonar A549

Las células A549 son células humanas de epitelio basal alveolar que provienen de una línea estable de adenocarcinoma de pulmón. Este modelo celular ya ha sido validado previamente en distintos estudios sobre la acción de los corticoides en la expresión de genes implicados en procesos alérgicos y en EPOC. Además, la línea celular A549, se ha utilizado previamente en estudios de expresión de PTGDR y su implicación en el asma.

\subsubsection{La línea celular A549 presenta una combinación haplotípica CTTT (-613, -549, -}

\section{1, -197) en el promotor de PTGDR}

Con el fin de caracterizar el cultivo utilizado, se llevó a cabo el análisis de genotipo para los polimorfismos del promotor de PTGDR que son objeto de estudio en este trabajo. De esta forma, mediante secuenciación automática se confirmó que la línea celular A549 contiene la combinación haplotípica CTTT en homocigosis para los polimorfismos $-613 \mathrm{C}>\mathrm{T},-549 \mathrm{~T}>\mathrm{C},-441 \mathrm{C}>\mathrm{T}$ y $-197 \mathrm{~T}>\mathrm{C}$.

\subsubsection{No se detecta expresión de PTGDR en la línea celular A549}

El análisis de la expresión del gen PTGDR mediante ensayos de PCR a tiempo real en cultivos de células A549 sin tratamiento, mostró una expresión prácticamente indetectable, con ciclos umbral (Ct) por encima de 35 en todos los ensayos realizados. 
Tampoco se detectaron cambios significativos en los niveles de expresión de PTGDR al tratar las células con dexametasona ni con su vehículo etanol.

\subsubsection{La línea celular A549 presenta un genotipo GG para el polimorfismo 6986A>G del} gen CYP3A5

Continuando con la caracterización genotípica de las células A549, se realizó un análisis de la combinación alélica para el polimorfismo 6986A>G en el gen CYP3A5. Este gen codifica una proteína del mismo nombre que forma parte del complejo multiproteico citocromo P450, y que interviene en el metabolismo de los glucocorticoides. Se comprobó que el cultivo presenta el genotipo GG en esta posición, el mayoritario en la población caucásica.

\subsubsection{La dexametasona activa la expresión de CYP3A5 en la línea celular A549}

Para asegurar la idoneidad del cultivo celular elegido, y su respuesta al tratamiento, se realizó un estudio de dosis-respuesta y tiempo-respuesta de la expresión del gen CYP3A5 tras someter al cultivo celular a la acción de la dexametasona.

En la figura 40 se muestran los cambios en los niveles de expresión de CYP3A5, analizados mediante PCR a tiempo real, que se producen tras la administración de dexametasona a dosis de $2,5 \times 10^{-6} \mathrm{M}$ y $2,5 \times 10^{-7} \mathrm{M}$ durante $12,24,36$ y 48 horas. Los datos se normalizaron con los datos obtenidos en las mismas condiciones temporales, pero con el vehículo de la dexametasona, en este caso etanol. 


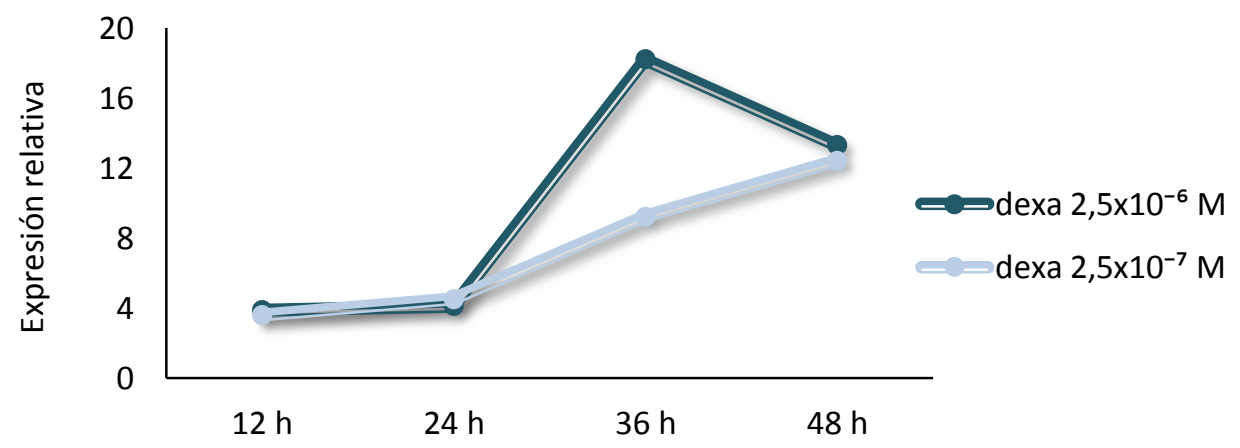

Figura 40: Análisis mediante PCR a tiempo real del nivel de expresión de CYP3A5 en respuesta al tratamiento corticoideo. Las células A549 fueron sometidas a tratamiento con dexametasona a $2,5 \times 10^{-6}$ $\mathrm{M}$ y $2,5 \times 10^{-7} \mathrm{M}$, durante $12,24,36$ y 48 horas. Los niveles de ARNm de CYP3A5 se normalizaron frente a los valores de ARNm del gen constitutivo GAPDH. Los resultados se muestran como la expresión relativa frente a los niveles de expresión obtenidos con etanol en las mismas condiciones.

Se observó que el incremento más importante de expresión de CYP3A5 se produjo a las 36 horas, y que fue la dosis de dexametasona de $2,5 \times 10^{-6} \mathrm{M}$ la que provocó aumentos más significativos en este tiempo. En este punto, la expresión de CYP3A5 tras el tratamiento con dexametasona superó en 18,22 veces la que se obtiene con el vehículo etanol.

Tras analizar estos datos, se estableció la concentración de $2,5 \times 10^{-6} \mathrm{M}$ para todos los ensayos realizados con posterioridad en este trabajo. Así mismo, se seleccionaron dos tiempos experimentales, 12 horas y 36 horas, a fin de poder hacer un seguimiento de la evolución temporal en los ensayos de actividad promotora, expresión y análisis de citocinas. 
5.2. Efecto de los polimorfismos en el promotor del gen PTGDR sobre su actividad promotora. Análisis del efecto del tratamiento corticoideo

Para el análisis de la actividad promotora del gen PTGDR se llevaron a cabo ensayos con el gen reportero de la luciferasa bajo el control de cada uno de los haplotipos a estudio (Figura 29). Los datos se presentan como la media de tres ensayos independientes, en los que en cada uno de ellos cada condición se determinó por triplicado.

\subsubsection{La activación del promotor es más evidente a las 12 horas que a las 36 horas}

Transcurridas 12 horas desde la transfección, en las células transfectadas con la secuencia silvestre del promotor de PTGDR, CTCT $(-613,-549,-441,-197)$, se obtuvo una media de 0,010 $\pm 0,009$ unidades relativas de luciferasa (URL). En el caso de las variantes CCCC, CCCT y TCCT para las mismas posiciones, las medias obtenidas fueron $0,114 \pm 0,009$ URL, 0,104 $\pm 0,012$ URL y 0,089 $\pm 0,010$ URL, respectivamente.

Cuando se determinó la señal de luciferasa a las 36 horas, se observó una ligera disminución de la actividad promotora de PTGDR en todas las variantes respecto a sus valores a las 12 horas, a excepción de la variante con la secuencia CTCT (Figura 41) que mantiene el $100 \%$ de su actividad. Los datos obtenidos a las 36 horas fueron significativamente inferiores a los obtenidos a las 12 horas $(p=0,006)$. Así, a las 36 horas, la variante polimórfica que presentó mayor actividad promotora fue la combinación CCCC $(0,103 \pm 0,004$ URL), y la que presentó una actividad menor fue la combinación TCCT $(0,075 \pm 0,004$ URL). Las variantes, CTCT y CCCT mostraron valores

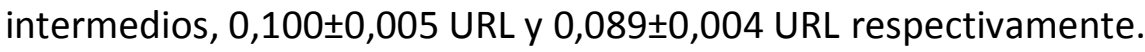




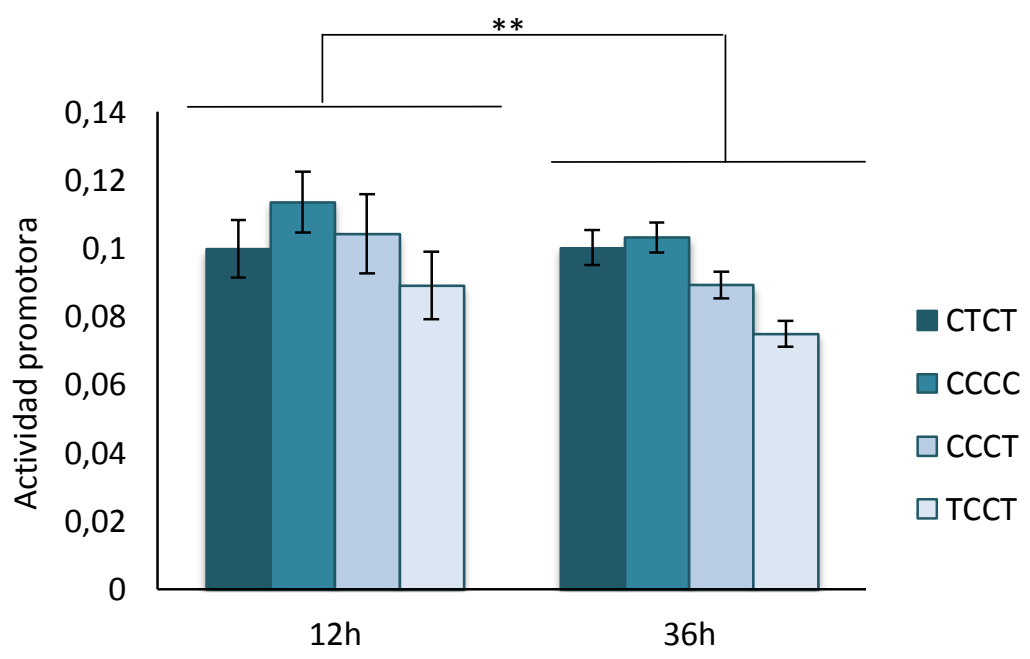

Figura 41: Actividad promotora de PTGDR tras 12 y $\mathbf{3 6}$ horas de cultivo. Las células A549 fueron transfectadas con los vectores portadores del gen reportero de la luciferasa y las combinaciones haplotípicas promotoras CTCT, CCCC, CCCT y TCCT. Los valores se representan como la media $\pm D E$ de las unidades relativas de luciferasa (URL) obtenidas tanto a las 12 horas como a las 36 horas. (**tStudent-p $<0,01 ; n=3)$.

\subsubsection{El haplotipo TCCT presenta la menor actividad promotora y CCCC la actividad más}

aumentada

Normalizando los datos de actividad promotora de las variantes frente a la forma silvestre CTCT, tras 12 horas de cultivo con medio sin tratamiento, la variante con el haplotipo CCCC se mostró como la combinación con mayor actividad promotora, superando a la variante silvestre en 1,14 veces, alcanzando significación estadística en comparación con el resto de variantes (vs CTCT $p=0,002$; vs CCCT $p=0,019$; vs TCCT $p$ $<0,001$ ). A su vez, la variante TCCT fue la que menor actividad presentó (vs CTCT p = 0,013 ; vs CCCC $p<0,001$; vs CCCT $p=0,002$ ) con un valor relativo de 0,89 respecto al haplotipo silvestre, CTCT (Figura 42).

Al aumentar el tiempo experimental a 36 horas, la variante TCCT siguió presentando la menor actividad promotora, alcanzando significación estadística en 
todos los cruces (vs CTCT $p=0,005$; vs CCCC $p=0,003$; vs CCCT $p=0,001$ ) (Figura 42). La variante CCCC siguió siendo la de mayor actividad aunque perdió la significación respecto a la silvestre.

Por otro lado, la variante CCCT mostró una actividad promotora significativamente menor que la variante de mayor actividad, $\operatorname{CCCC}(p=0,028)$, y que la silvestre, СTCT $(p=0,025)$.

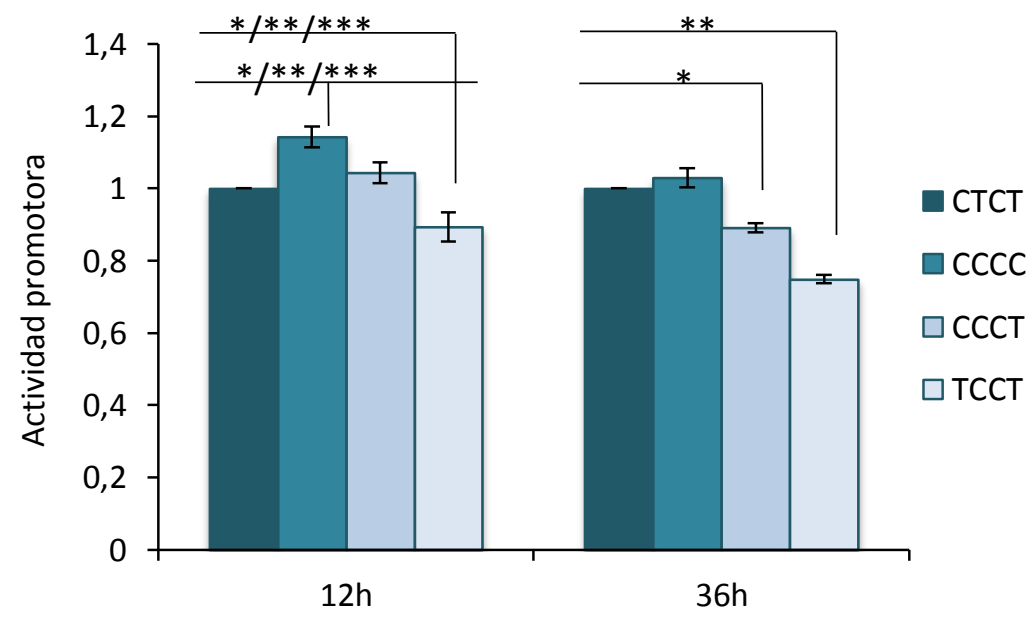

Figura 42: Efecto de las variantes polimórficas de PTGDR sobre su actividad promotora. Las células A549 fueron transfectadas con los vectores portadores del gen reportero de la luciferasa y las combinaciones haplotípicas promotoras CTCT, CCCC, CCCT y TCCT. Los valores se representan como la media $\pm D E$ de las unidades relativas de luciferasa (URL) obtenidas tanto a las 12 horas como a las 36 horas, $y$ tras normalizar frente a la variante silvestre CTCT $\left({ }^{*}\right.$ Fisher- $\mathrm{p}<0,05 ;{ }^{* *}$ Fisher- $\mathrm{p}<0,01 ;{ }^{* * *}$ Fisher$p<0,001 ; n=3)$.

\subsubsection{La dexametasona produce un aumento de la actividad promotora}

Para realizar el estudio del efecto del tratamiento con dexametasona sobre la activación de la región promotora del gen PTGDR, se han tratado las células con el diluyente del fármaco, en este caso etanol, de forma paralela al tratamiento corticoideo. Aunque no se observaron diferencias estadísticamente significativas entre 
los datos de actividad promotora en las células no tratadas y las células tratadas con el vehículo etanol, $\mathrm{ni}$ a las 12 horas (tStudent-p $=0,299$ ) ni a las 36 horas (tStudent- $\mathrm{p}=$ 0,386), se han utilizado los datos obtenidos en la condición con etanol como actividad basal en las comparaciones del efecto del tratamiento con dexametasona para evitar cualquier sesgo (Figura 43).

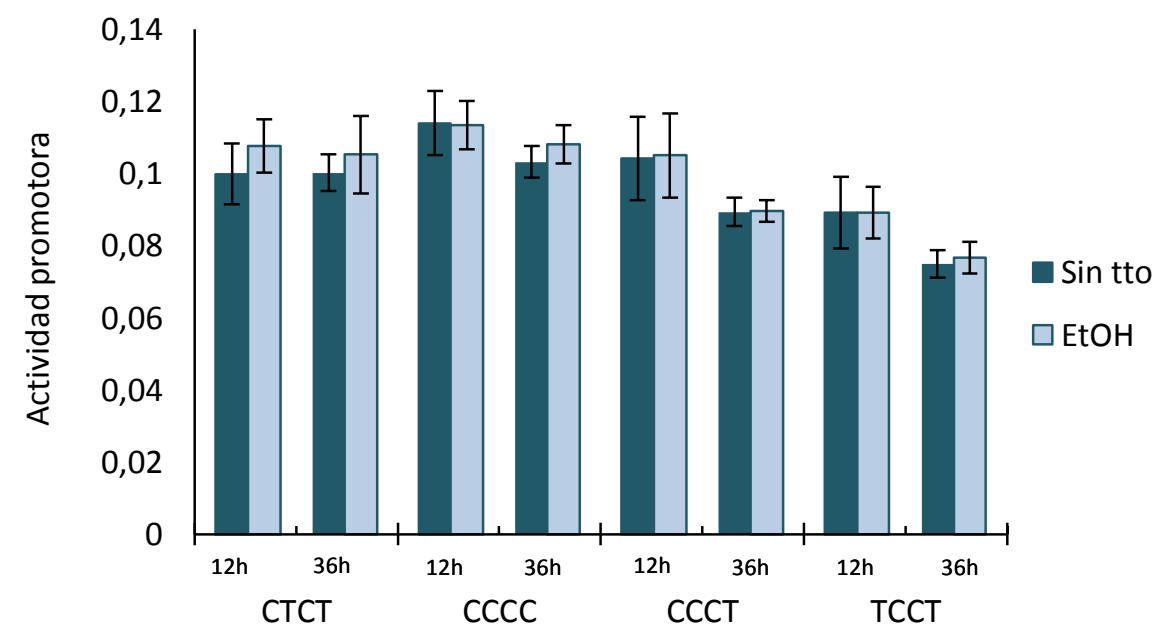

Figura 43: Actividad promotora de las cuatro variantes polimórficas de PTGDR en condición basal sin tratamiento y con etanol. Tras transfectar las células con los vectores reporteros portadores de las combinaciones haplotípicas promotoras, se mantuvo un grupo sin tratamiento y otro tratado con etanol durante 12 y 36 horas. Los valores se representan como la media $\pm D E$ de las unidades relativas de luciferasa (URL) obtenidas en cada condición ( $n=3$ ).

Antes de realizar el análisis comparativo entre las distintas variantes polimórficas del promotor PTGDR, se comprobó que en todas ellas el tratamiento con dexametasona a $2,5 \times 10^{-6} \mathrm{M}$ provocó un aumento significativo en la actividad promotora, tanto a las 12 horas (CTCT $p=0,008$; CCCC $p=0,001 ;$ CCCT $p=0,004$; TCCT $p=0,002)$, como a 36 horas (СTCT $p=0,014$; CCCC $p=0,026$; CCCT $p=0,026$; TCCT $p=$ 0,024) frente al etanol. Este aumento fue más acusado a las 12 horas que a las 36 
horas, aunque manteniendo la significación en comparación con los datos del etanol (Figura 44).

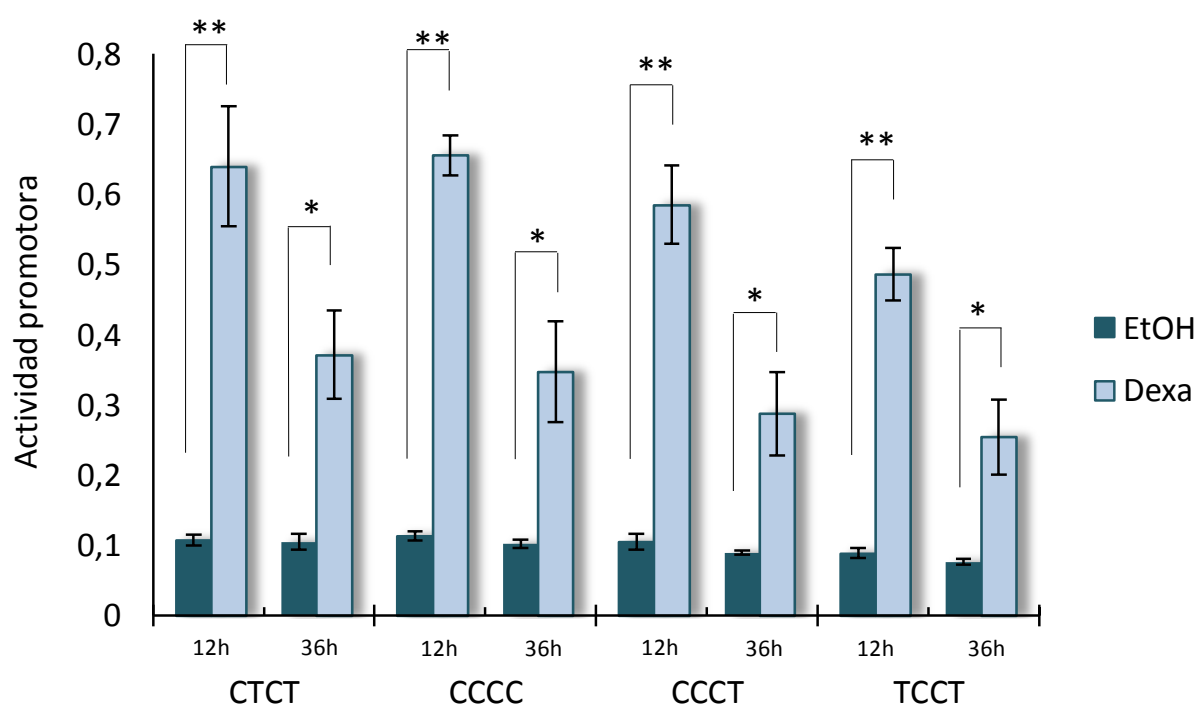

Figura 44: Efecto del tratamiento con dexametasona en la actividad promotora de las cuatro variantes polimórficas de PTGDR. Tras transfectar las células con los vectores reporteros portadores de las combinaciones haplotípicas promotoras, se trató un grupo con dexametasona $2,5 \times 10^{-6} \mathrm{M}$ y otro grupo con etanol durante 12 y 36 horas. Los valores se representan como la media $\pm D E$ de las unidades relativas de luciferasa (URL) obtenidas en cada condición ( ${ }^{*}$ tStudent- $p<0,05 ; * *$ tStudent- $p<0,01 ; n=3$ ).

\subsubsection{Tras el tratamiento con dexametasona la variante TCCT mantiene el menor nivel} de actividad mientras que la variante CTCT presenta el mayor nivel de actividad

Para poder comparar los niveles de actividad entre las cuatro variantes tras el tratamiento con dexametasona, se restaron a cada uno de los valores obtenidos de cada una de las combinaciones polimórficas los resultados obtenidos en la condición basal (con etanol), para así eliminar el fondo y visualizar mejor los cambios producidos únicamente por el glucocorticoide. De esta forma, resultó ser la forma silvestre CTCT la condición de mayor actividad promotora tras 36 horas de tratamiento. Además, se 
confirmó que la variante TCCT se mantuvo como la de menor expresión, también tras el tratamiento corticoideo.

Así, transcurridas 12 horas de tratamiento de las células transfectadas con dexametasona, y considerando como valor 1 el aportado por la secuencia silvestre CTCT, las variantes CCCC y CCCT no mostraron variaciones significativas, con una actividad de $1,02 \pm 0,09$ y $0,91 \pm 0,05$, respectivamente. Sin embargo, la variante TCCT mostró una actividad menor que cualquiera de las otras variantes, con un valor de 0,75 $\pm 0,06$ veces el del haplotipo silvestre (Figura 45). Esta diferencia alcanzó significación estadística frente a CTCT $(p=0,006)$ y frente a CCCC $(p=0,003)$.

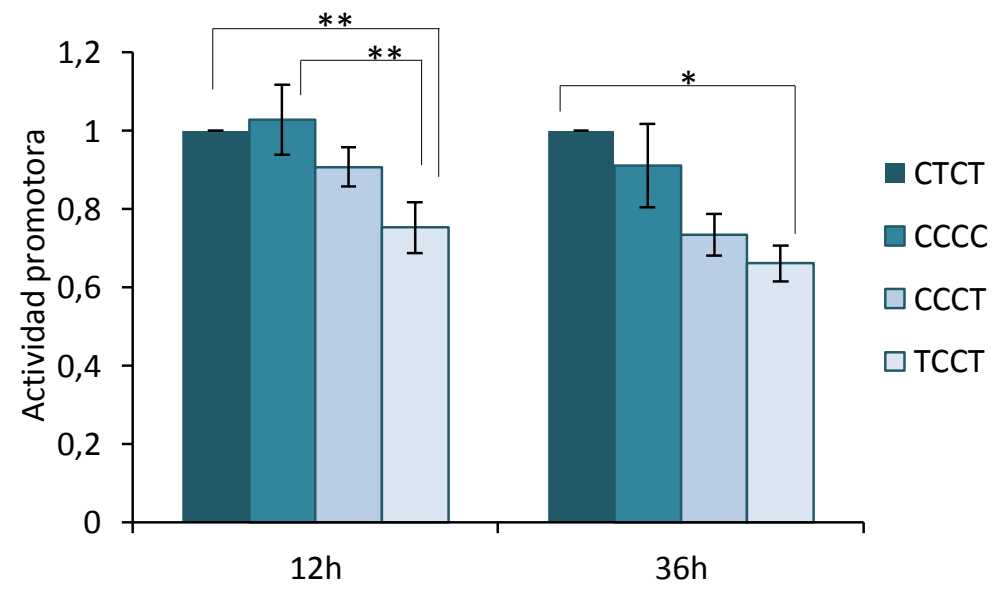

Figura 45: Nivel de actividad promotora tras el tratamiento con dexametasona. Las células transfectadas con los vectores reporteros portadores de las combinaciones haplotípicas promotoras se trataron con dexametasona $2,5 \times 10^{-6} \mathrm{M}$ y con etanol, en grupos independientes, durante 12 y 36 horas. Los valores se representan como la media $\pm D E$ de la diferencia de las unidades relativas de luciferasa (URL) obtenidas con dexametasona menos las obtenidas con el etanol, y normalizados frente al haplotipo silvestre CTCT (*Fisher-p <0,05; **Fisher-p <0,01; $n=3$ ).

Tras 36 horas de exposición a dexametasona, la combinación silvestre CTCT mostró la mayor actividad promotora, y la variante TCCT se mantuvo como el 


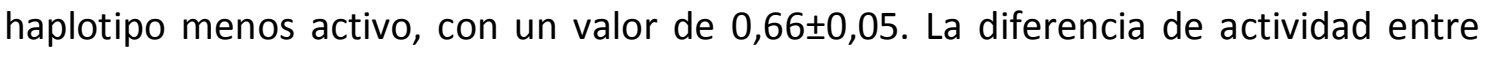
ambas alcanzó una asociación estadísticamente significativa con un $p=0,036$ (Figura

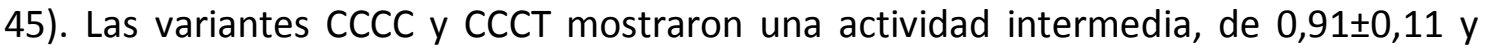
$0,73 \pm 0,05$, respectivamente.

5.3. Estudio del efecto de los polimorfismos en el promotor del gen PTGDR sobre su expresión génica. Análisis del efecto del tratamiento corticoideo

Una vez establecidas las diferencias de actividad promotora entre las cuatro variantes polimórficas del gen PTGDR, se procedió al análisis de las diferencias en los niveles de expresión génica. Para ello, las cuatro combinaciones del promotor, CTCT, CCCC, CCCT y TCCT $(-613,-549,-441$ y -197), se clonaron en un vector de expresión portador de la secuencia codificante completa del gen (Figura 31). Los datos aportados corresponden con las medias de los dos ensayos de expresión realizados de manera independiente.

Los niveles de PTGDR en las células transfectadas con cualquiera de los vectores portadores de las variantes promotoras fueron muy superiores a los niveles que se encontraron en las células transfectadas con el vector vacío, alcanzándose niveles de expresión más de mil veces superiores. Estos datos sirvieron para corroborar que las construcciones utilizadas funcionaban correctamente.

\subsubsection{La presencia de polimorfismos en el promotor de PTGDR varía su expresión}

Tras 12 horas de cultivo en condición basal de no tratamiento, se encontraron diferencias de expresión entre las distintas combinaciones haplotípicas (Figura 46). La 
variante que presentó un menor valor de expresión relativa $(\triangle \Delta \mathrm{Ct})$ de $P T G D R$ fue la variante TCCT $(2,5 \mathrm{E} 3 \pm 1,6 \mathrm{E} 3)$, seguida de la variante silvestre CTCT $(4,2 \mathrm{E} 3 \pm 3,9 \mathrm{E} 3)$ y de la variante $\operatorname{CCCC}(4,4 \mathrm{E} 3 \pm 4,1 \mathrm{E} 3)$. Por último, la variante con mayor expresión fue la variante CCCT $(4,9 E 3 \pm 4,8 E 3)$. Aunque la diferencia entre la variante TCCT y el resto fue de casi el doble, debido a una elevada desviación estándar, no se observaron diferencias estadísticamente significativas entre las variantes.

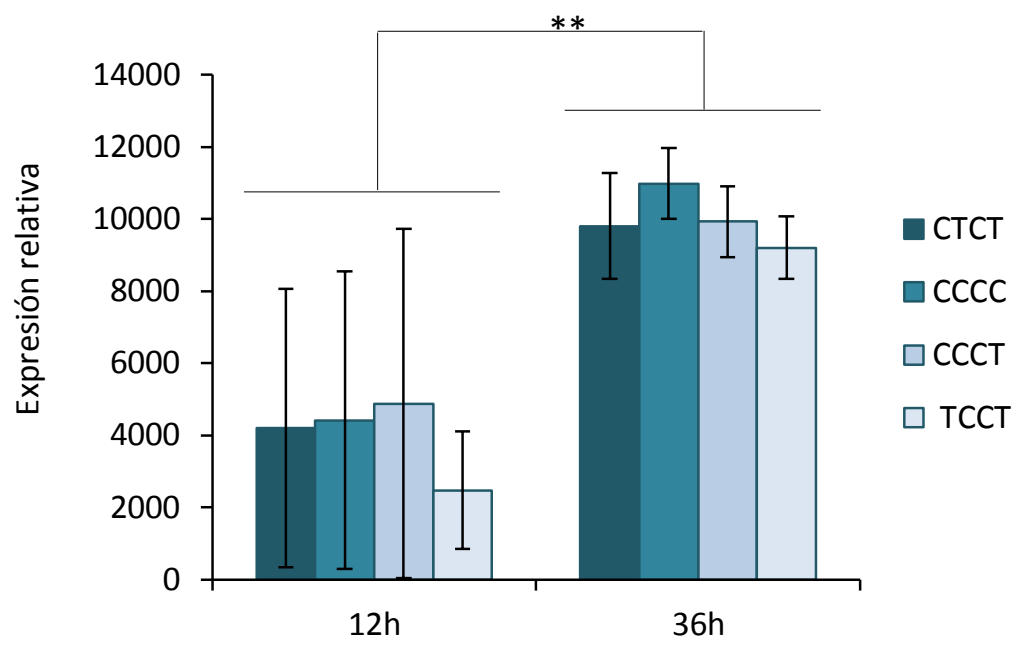

Figura 46: Análisis mediante PCR a tiempo real del nivel de expresión de PTGDR según la combinación haplotípica de su promotor tras 12 y 36 horas de cultivo. Los niveles de ARNm de PTGDR se normalizaron frente a los valores de ARNm del gen constitutivo GAPDH. Los resultados se muestran como la media $\pm D E$ de la expresión relativa frente a los niveles de expresión obtenidos en las células control transfectadas con el vector pCMV-XL5 (**Wilcoxon-p<0.01; $n=2)$.

Tras 36 horas de cultivo, todas las variantes presentaron un aumento significativo de la expresión de PTGDR con respecto a los datos obtenidos a las 12 horas $(p=0,008)$. A este tiempo, la variante silvestre CTCT mostró un valor de

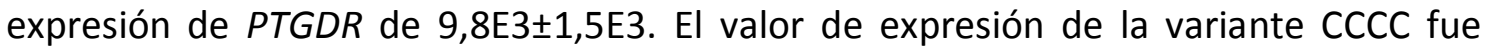
ligeramente mayor, de 10,9E3 $\pm 0,9 \mathrm{E} 3$, igual que el de CCCT que fue de $9,9 \mathrm{E} 3 \pm 1,9 \mathrm{E} 3$. La 
variante TCCT se mantuvo como la de menor expresión, 9,2E3 $\pm 0,9 \mathrm{E} 3$, aunque no se observaron diferencias estadísticamente significativas con el resto.

\subsubsection{El etanol, vehículo de la dexametasona, afecta al nivel de expresión de PTGDR}

Una vez establecido el comportamiento basal de las cuatro variantes polimórficas del promotor de PTGDR, el siguiente paso que nos planteamos es estudiar cómo varía la expresión génica tras la exposición a un tratamiento corticoideo. Para ello, y de forma similar a los ensayos de luciferasa, se trataron las células con dexametasona a una concentración de $2,5 \times 10^{-6} \mathrm{M}$ durante 12 y 36 horas. Otro grupo de células fue tratado con una concentración equivalente de etanol, diluyente del corticoide, para establecer una línea base.

Tras un análisis inicial de los datos, se comprobó que el tratamiento de las células con el vehículo (etanol) provocó cambios en los niveles de PTGDR al compararlo con las células en situación basal (Figura 47). La expresión de PTGDR fue significativamente mayor en las células sometidas al efecto del etanol tanto a las 12 horas como a las $36 \mathrm{~h}(\mathrm{p}=0,007)$.

Los niveles de expresión relativa alcanzados por las variantes CTCT, CCCC, CCCT y TCCT tras 12 horas de cultivo con la presencia de etanol en el medio fueron $13,8 \mathrm{E} 3 \pm 10,1 \mathrm{E3} ; 11,9 \mathrm{E} 3 \pm 6,9 \mathrm{E} 3 ; 13,2 \mathrm{E} 3 \pm 8,9 \mathrm{E} 3$ y $10,8 \mathrm{E} 3 \pm 4,8 \mathrm{E} 3$, respectivamente. De nuevo fue la variante TCCT la que presentó una menor expresión.

Cuando se midió la expresión de PTGDR tras 36 horas de cultivo con etanol, los valores aumentaron de manera significativa con respecto a los valores a 12 horas $(p=$ 0,008), alcanzado valores de $33,1 \mathrm{E} 3 \pm 14,1 \mathrm{E} 3 ; 37,4 \mathrm{E} 3 \pm 13,4 \mathrm{E} 3 ; 35,9 \mathrm{E} 3 \pm 15,4 \mathrm{E} 3$ y 
30,6E3 $\pm 17,4 \mathrm{E} 3$ (CTCT, CCCC, CCCT y TCCT respectivamente). En este caso, también fue la variante TCCT la que menor expresión de PTGDR provocó.

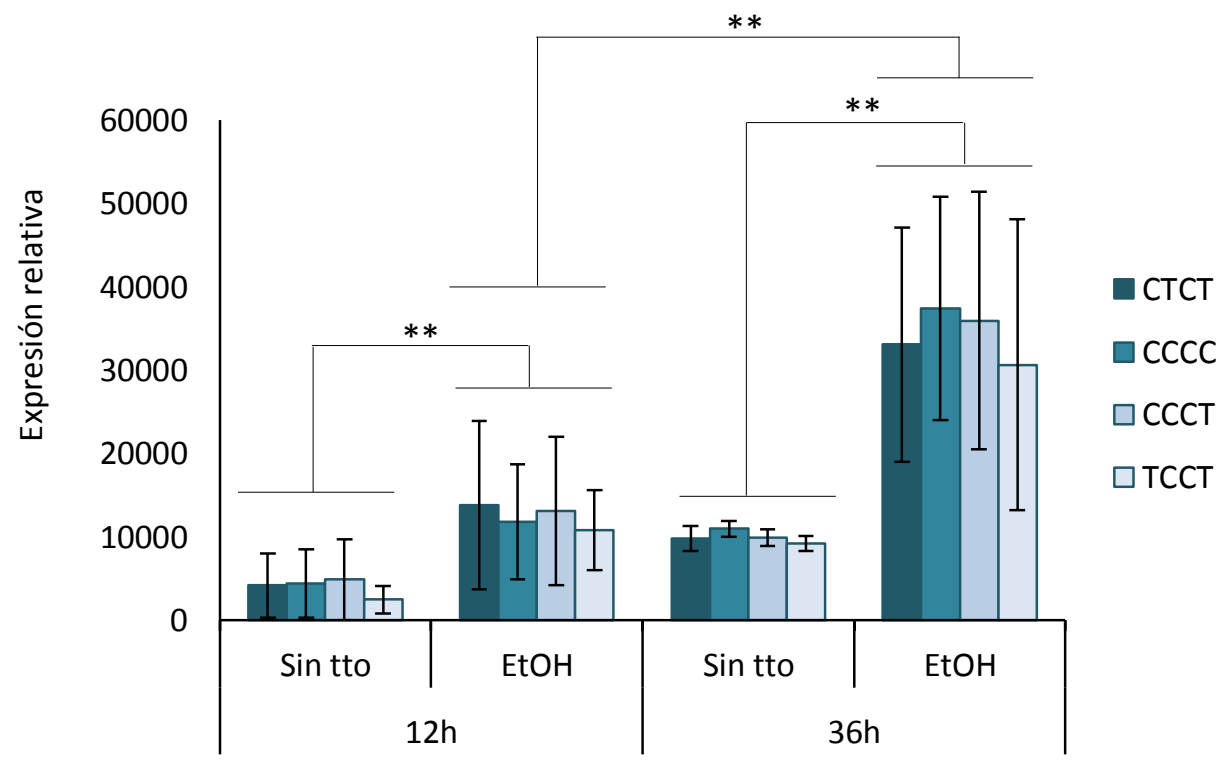

Figura 47: Comparación mediante PCR a tiempo real de los niveles de expresión de PTGDR en células no tratadas y células tratadas con etanol. Los resultados se muestran como la media $\pm D E$ de la expresión relativa frente a los niveles de expresión obtenidos en las células control transfectadas con el

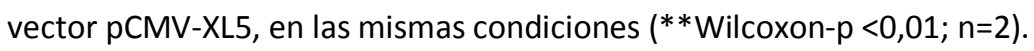

\subsubsection{El efecto de la dexametasona sobre la expresión de PTGDR varía a lo largo del}

$\underline{\text { tiempo }}$

Tras someter a las células A549 a una concentración de dexametasona 2,5×10-6 M durante 12 horas, la expresión de PTGDR, en todas las variantes, sufrió una disminución de casi la mitad con respecto a la situación control con etanol ( $p=0,007)$. Sin embargo, tras 36 horas de tratamiento, los niveles de PTGDR aumentaron en más del doble en las cuatro combinaciones haplotípicas con respecto a los valores obtenidos con etanol $(p=0,007)$ (Figura 48). 


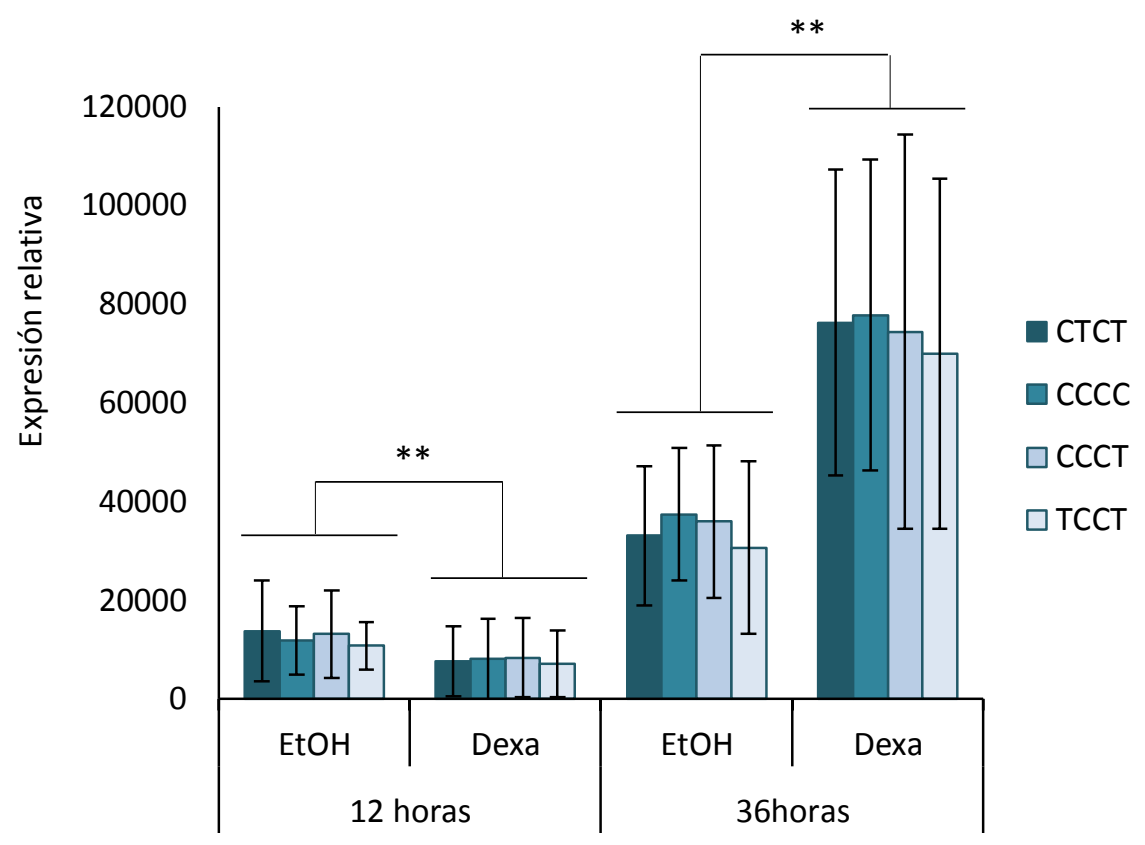

Figura 48: Comparación mediante PCR a tiempo real de los niveles de expresión de PTGDR en células tratadas con dexametasona y células tratadas con etanol. Se utilizó una concentración de dexametasona de $2,5 \times 10^{-6} \mathrm{M}$, y un volumen equivalente de etanol. Los resultados se muestran como la media $\pm D E$ de la expresión relativa frente a los niveles de expresión obtenidos en las células control transfectadas con el vector $\mathrm{PCMV}-\mathrm{XL} 5$, en las mismas condiciones ( $* *$ Wilcoxon- $\mathrm{p}<0,01 ; n=2$ ).

\subsubsection{El efecto de la dexametasona sobre la expresión de PTGDR varía dependiendo de} la combinación haplotípica presente en su promotor

Para realizar un análisis comparativo de los niveles de expresión total de PTGDR en función de la variante haplotípica presente en su promotor, se restó el fondo obtenido con el etanol a los valores mostrados con la dexametasona. De esta forma, el dato resultante corresponde únicamente al efecto causado por el corticoide eliminando el efecto provocado por el vehículo en el que está disuelto.

Como se ha comentado anteriormente, tras 12 horas de tratamiento, las células sometidas a la acción del corticoide presentaron una disminución de la expresión de 
PTGDR respecto a las células que recibieron etanol. De esta forma, la variante silvestre СTCT fue la que mostró una disminución de la expresión más acusada tras el tratamiento con dexametasona a 12 horas (Figura 49), con una expresión de $6,2 \mathrm{E} 3 \pm 3,0 \mathrm{E} 3$ puntos menos que con etanol. En contraposición, la variante TCCT mostró la menor disminución de las cuatro variantes, con una expresión 3,7E3 $31,9 \mathrm{E} 3$ puntos menos que con etanol. Las variantes CCCC y CCCT presentaron una expresión de $3,7 \mathrm{E} 3 \pm 1,3 \mathrm{E} 3$ y $4,8 \mathrm{E} 3 \pm 0,8 \mathrm{E} 3$ puntos de diferencia entre el corticoide y su vehículo. Esto se traduce en que la variante silvestre CTCT presenta mayor respuesta al tratamiento con dexametasona, aunque sin alcanzar significación estadística respecto al resto.

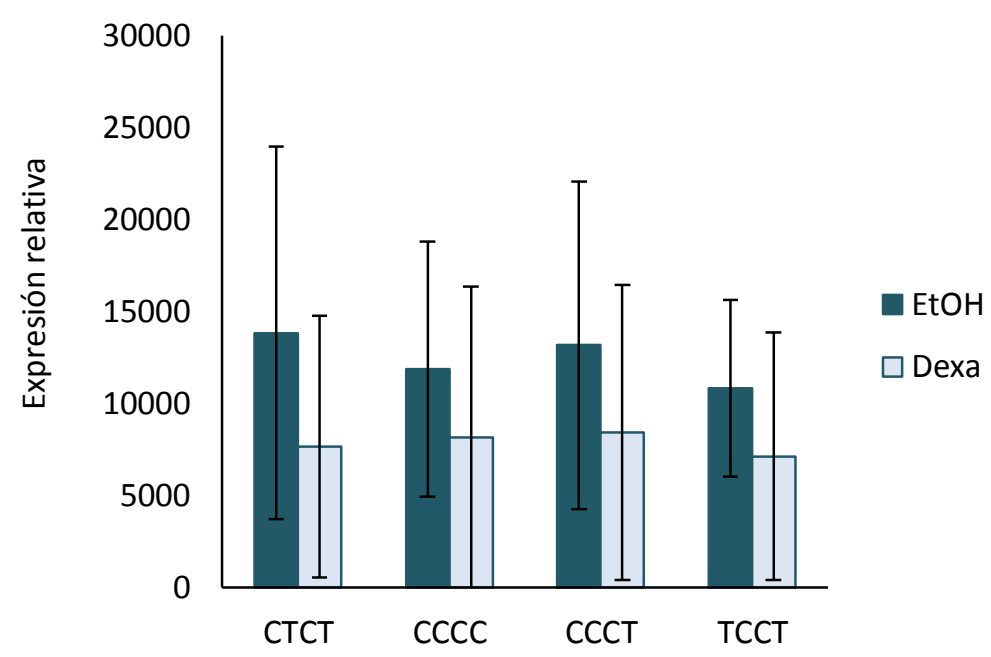

Figura 49: Diferencia de expresión de PTGDR entre el tratamiento con dexametasona y con el vehículo

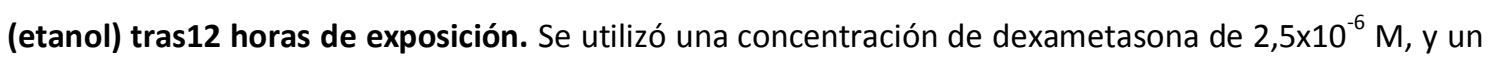
volumen equivalente de etanol. Los resultados se muestran como la media $\pm D E$ de la expresión relativa frente a los niveles de expresión obtenidos en las células control transfectadas con el vector pCMV-XL5, en las mismas condiciones $(\mathrm{n}=2)$.

Los datos obtenidos tras 36 horas de tratamiento mostraron un cambio de expresión en sentido contrario al que se produjo a las 12 horas. A este tiempo experimental, el tratamiento con dexametasona provocó un aumento de los niveles de 
PTGDR con respecto a los valores con etanol. La variante con el haplotipo silvestre CTCT fue la que mayor aumento presentó, con una media de $43,2 \mathrm{E} 3 \pm 16,9 \mathrm{E} 3$, aunque no se obtuvieron diferencias estadísticamente significativas con el resto, mostrando las variantes CCCC, CCCT у TCCT un aumento de 40,4E3 $\pm 18,1 \mathrm{E3} ; 38,5 \mathrm{E} 3 \pm 24,4 \mathrm{E} 3$ y $39,3 E 3 \pm 18,1 \mathrm{E} 3$, respectivamente (Figura 50).

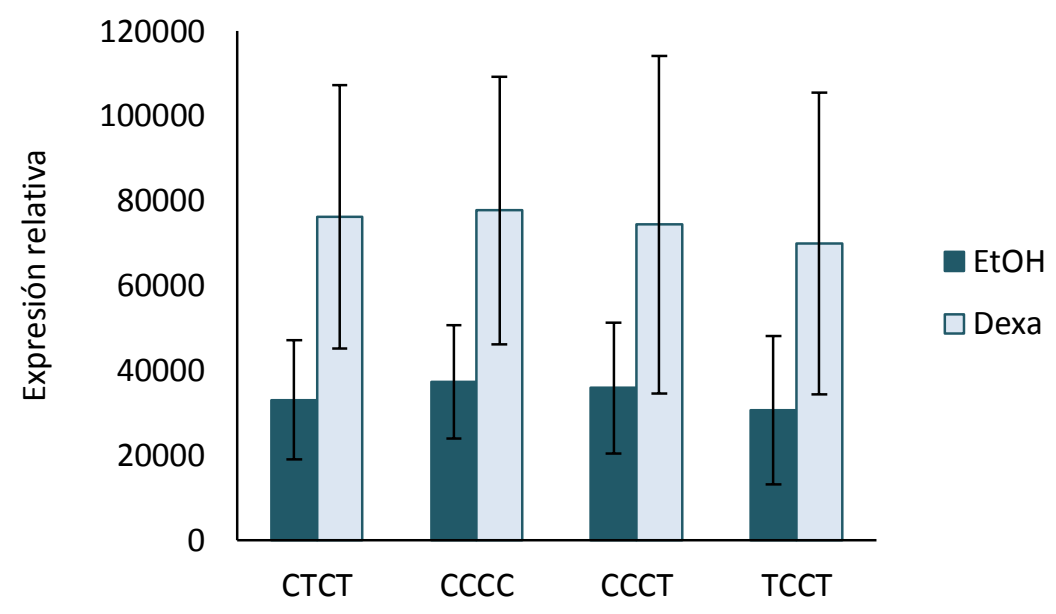

Figura 50: Diferencia de expresión de PTGDR entre el tratamiento con dexametasona y con el vehículo

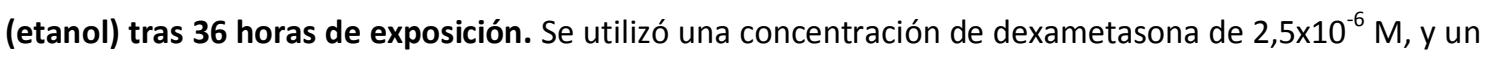
volumen equivalente de etanol. Los resultados se muestran como la media $\pm D E$ de la expresión relativa frente a los niveles de expresión obtenidos en las células control transfectadas con el vector PCMV-XL5, en las mismas condiciones $(n=2)$.

5.4. Estudio in silico de los cambios en los factores de transcripción en cada una de las variantes del promotor del gen PTGDR

Mediante el análisis in silico llevado a cabo se detectaron diferencias en el posible patrón de unión de factores de transcripción entre las cuatro variantes polimórficas del promotor de PTGDR analizadas en este trabajo. El estudio realizado, basado en los algoritmos MatInspector y Transfac (Biobase), predice cambios en los 
potenciales sitios de unión dependiendo de la presencia del alelo silvestre o mutado de las posiciones $-613,-549,-441$ y -197 (Tabla 12).

Cambio -613 C>T: La primera base de datos bioinformática, Matlnspector, establece que únicamente la presencia del alelo silvestre en la posición -613C>T permite la unión de GZF1. Cuando está presente la base mutada (timina), este sitio de unión se pierde, pero aparecen potenciales sitios de unión para SOX15, MAFB y MAFF que no estaban presentes con el nucleótido conservado citosina. Cuando se analizan las secuencias con el algoritmo Transfac (Biobase), no se detectan sitios de unión para ningún factor de trascripción en las posiciones -613 ni en presencia del alelo silvestre ni tampoco en presencia del alelo mutado.

Cambio -549 T>C: Para la posición -549T>C del promotor de PTGDR, MatInspector pronostica que la presencia del alelo mutado, citosina, en lugar del silvestre, timina, origina la pérdida de sitios de interacción para los factores de transcripción PPAR- $\gamma$, NBRE y los heterodímeros CAR/RXR y VDR/RXR. A su vez, este cambio nucleotídico en -549 provoca la aparición de nuevos sitios de unión para ZFP652, PAX6 y GABP y FREAC2. Cuando se analizan las secuencias con el algoritmo Transfac (Biobase) para el sitio de interés, -549 , se establece una pérdida de afinidad para los factores de transcripción NF-ATp, ISGF-3, NF-ATc, NF-ATx y SF-1 cuando está presente el cambio -549 T>C. Además, es importante señalar que, en esta posición, el algoritmo predice la pérdida de un sitio de unión para el receptor de glucocorticoide (GR) en presencia de la base mutada citosina. Esto hace que las tres variantes mutadas CCCC, CCCT y TCCT, que tienen el cambio en posición -549, cuenten con un sitio menos de unión a GR que la variante silvestre CTCT. 
Tabla 12: Resultados del análisis in silico del promotor de PTGDR con las plataformas de MatInspector y Transfac (Biobase). En rojo se representan los factores cuya unión se ve modificada al introducir el cambio de nucleótido correspondiente en cada polimorfismo.

\begin{tabular}{|c|c|c|c|c|c|}
\hline & & $-613 C>T$ & $-549 \mathrm{~T}>\mathrm{C}$ & $-441 \mathrm{C}>\mathrm{T}$ & $-197 \mathrm{~T}>\mathrm{C}$ \\
\hline \multirow{2}{*}{ 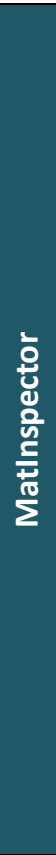 } & Silvestre & $\begin{array}{c}\text { E2F } \\
\text { GZF1 }\end{array}$ & $\begin{array}{c}\text { BACH1 } \\
\text { CAR/RXR } \\
\text { PPARG } \\
\text { MEF2 } \\
\text { HNF3B } \\
\text { EVI1 } \\
\text { NBRE } \\
\text { PPARG } \\
\text { VDR/RXR } \\
\text { BCL6 }\end{array}$ & $\begin{array}{c}\text { LXRE } \\
\text { NRSF } \\
\text { ZNF263 } \\
\text { THRB }\end{array}$ & $\begin{array}{c}\text { E2F1 } \\
\text { SP2 } \\
\text { KKLF } \\
\text { EOMES }\end{array}$ \\
\hline & Mutado & $\begin{array}{l}\text { E2F } \\
\text { SOX15 } \\
\text { MAFB } \\
\text { MAFF }\end{array}$ & $\begin{array}{c}\text { BACH1 } \\
\text { MEF2 } \\
\text { HNF3B } \\
\text { EVI1 } \\
\text { PPARG } \\
\text { ZFP652 } \\
\text { PAX6 } \\
\text { GABP } \\
\text { BCL6 } \\
\text { FREAC2 }\end{array}$ & $\begin{array}{c}\text { LXRE } \\
\text { PPAR/RXR } \\
\text { ZNF263 } \\
\text { THRB }\end{array}$ & $\begin{array}{c}\text { E2F1 } \\
\text { SP2 } \\
\text { MAZ } \\
\text { SRF } \\
\text { KKLF } \\
\text { EOMES }\end{array}$ \\
\hline \multirow{2}{*}{ 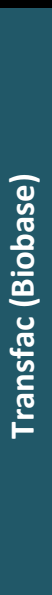 } & Silvestre & & $\begin{array}{c}\text { NF-ATp } \\
\text { ISGF-3 } \\
\text { NF-ATc, } \\
\text { NF-ATp, } \\
\text { NF-ATx } \\
\text { SF-1 } \\
\text { GR }\end{array}$ & & \\
\hline & Mutado & & & & $\begin{array}{c}\text { IRE-ABP, SRY } \\
\text { SP1 } \\
\text { LyF-1 } \\
\text { AP-2alphaA } \\
\text { AP-2alphaB } \\
\text { FREAC2 } \\
\text { CBF, SRF }\end{array}$ \\
\hline
\end{tabular}

E2F: E2 factor. GZF1: GDNF inducible zinc finger protein 1. BACH1: BTB and CNC homology 1, basic leucine zipper transcription factor 1. CAR: Constitutive androstane receptor. RXR: retinoid $X$ receptor: PPAR-叉: Peroxisome proliferator-activated receptor gamma. MEF2: Myocyte-specific enhancer factor 2. HNF3B: Hepatocyte Nuclear Factor 3, Beta. EVI1: Ecotropic viral integration site 1 encoded

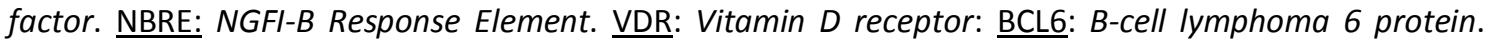
LXRE: LXR response element. NRSF: Neuron restrictive silencer factor. ZNF263: Zinc finger protein 263. THRB: Thyroid Hormone Receptor, Beta. Sp2: Specificity protein 2. KKLF: Kidney-enriched Krüppel-like factor. EOMES: Eomesodermin. SOX15: Sry-related HMG box gene 15. MAFB: V-Maf Avian 
Musculoaponeurotic Fibrosarcoma Oncogene Homolog B. MAFF: V-Maf Avian Musculoaponeurotic Fibrosarcoma Oncogene Homolog F. ZFP652: Zinc finger protein 652. PAX-6: Paired box protein 6. GABP: GA binding protein. FREAC2: Forkhead-related activator 2. MAZ: Myc associated zinc finger protein. SRF: Serum response factor. NF-ATp: Nuclear factor of activated T cells, phosphoprotein. ISGF-3: Interferonstimulated gene factor 3. NF-ATc: Nuclear factor of activated T cells, Cytoplasmic, calcineurin dependent 1. NF-ATX: Nuclear factor of activated T cells X. SF-1: Splicing factor 1. GR: Glucocorticoid receptor. IREABP: Insulin response element-A binding protein. SRY: Sex determining region Y. SP1: Specificity Protein 1. LyF-1: lymphoid transcription factor 1. AP-2alphaA: activating enhancer binding protein 2 alpha A. AP2alphaB: activating enhancer binding protein 2 alpha B. CBF: Core binding factor.

Cambio -441 C>T: En cuanto a la posición -441C>T, la presencia del alelo mutado provoca la pérdida de la capacidad de unión del factor de transcripción NRSF, y a su vez provoca la aparición de un sitio de unión del heterodímero PPAR/RXR, según la base de datos MatInspector.

Cambio -197 T>C: Por último, según el algoritmo utilizado por MatInspector, el cambio en -197 de timina por citosina permite la unión teórica de MAZ y SRF, que no aparecía con el alelo silvestre. Según el análisis realizado con Transfac (Biobase), la presencia esta vez del alelo mutado en la posición -197 T>C provoca la aparición de sitios de unión teóricos para los factores de transcripción IRE-ABP, SRY, SP1, LyF-1, AP2alphaA, AP-2alphaB, FREAC2, CBF y SRF, que no aparecen con el nucleótido conservado.

5.5. Análisis del efecto de la presencia de polimorfismos en el promotor de PTGDR sobre la expresión de citocinas

Con la finalidad de estudiar el efecto que pudiera tener la expresión de PTGDR sobre la cascada inflamatoria, se ha analizado la secreción de citocinas producida por 
las células A549 transfectadas con los vectores de expresión de este gen. Como en el resto de los experimentos, también se han estudiado los efectos derivados la exposición a dexametasona $2,5 \times 10^{-6} \mathrm{M}$, evaluándolos tras 12 horas y tras 36 horas del inicio del tratamiento.

\subsubsection{La transfección de PTGDR en las células A549 modifica el patrón de expresión de}

\section{la citocinas}

- A las 12 horas comienza un incremento generalizado de expresión de citocinas para todos los haplotipos

En la tabla 13 se muestran las concentraciones obtenidas de las citocinas producidas por las células portadoras de las variantes del vector de expresión de PTGDR (con las cuatro combinaciones haplotípicas del promotor), así como las producidas por las células control (transfectadas con el vector control pCVM-XL5). EI patrón de expresión de citocinas fue el mismo en todos los casos, siendo IP-10 la citocina que mayores niveles mostró, seguida de MCP-1, IL-8, RANTES, VEGF, MIP-1b, IL-12, IL-6, INF-ү e IL-7, en este orden (excepto las dos últimas en el caso de CTCT, que tenían el orden invertido).

Se ha comprobado que la transfección de las células con los vectores de expresión portadores de las distintas variantes del promotor de PTGDR junto con la secuencia codificante del gen provocó un aumento del nivel de citocinas, comparándolo con los niveles obtenidos en las células control, excepto en el caso de la variante TCCT para las citocinas IL-7, IL-12, MCP-1, RANTES, donde se observó una ligera disminución, que fue más acusada en el caso de VEGF. 
Tabla 13: Patrón de citocinas expresadas a 12 horas sin tratamiento.

\begin{tabular}{|c|c|c|c|c|c|}
\hline \multirow{2}{*}{ pg/ml } & \multicolumn{5}{c}{ Expresión de citocinas tras 12h sin tratamiento } \\
& Control & CTCT & CCCC & CCCT & TCCT \\
\hline IP-10 & 2020,58 & 3035,51 & 2870,04 & 2469,54 & 2307,85 \\
\hline MCP-1 & 1624,3 & 1822,87 & 1813,28 & 1841,47 & 1468,75 \\
\hline IL8 & 648,76 & 835,42 & 763,98 & 712,74 & 714,21 \\
\hline RANTES & 457,37 & 640,67 & 556,71 & 475,31 & 452,89 \\
\hline VEGF & 352,28 & 454 & 392,13 & 396,21 & 273,29 \\
\hline MIP-1b & 51,83 & 84,97 & 75,09 & 65,35 & 61,83 \\
\hline IL12 & 46,1 & 65,26 & 56,65 & 49,26 & 41,69 \\
\hline IL6 & 24,07 & 39,08 & 37,77 & 31,99 & 30,64 \\
\hline IL7 & 25,96 & 30,2 & 28,78 & 25,96 & 24,57 \\
\hline IFN- $\boldsymbol{1} \boldsymbol{1 1 , 6 8}$ & 34,6 & 26,19 & 18,51 & 18,51 \\
\hline
\end{tabular}

- A las 12 horas, los niveles de citocinas más bajos se observan en el haplotipo TCCT, y los más altos en CTCT

Aunque el patrón general de citocinas fue el mismo en todos los haplotipos, sí se observaron diferencias en cuanto a su concentración, dependiendo de la variante del promotor de PTGDR presente en las células (Figura 51). Si otorgamos el valor 1 a la variante silvestre, de forma generalizada, tras 12 horas de cultivo en condiciones basales, es esta variante CTCT la que mostró una mayor concentración de citocinas, con la única excepción de MCP-1. En las combinaciones CCCC, CCCT y TCCT se han detectado concentraciones progresivamente más bajas, siendo la variante TCCT la que presentó menor expresión en la mayoría de las citocinas.

Por lo tanto, tras 12 horas de cultivo, las mayores diferencias se han observado entre la variante silvestre CTCT y la combinación TCCT $(-613,-549,-441,-197)$. Los casos más evidentes se han obtenido en las citocinas IL-12, INF- $\gamma$ y VEGF, en las que las 
células transfectadas con la combinación TCCT en el promotor de PTGDR mostraron una concentración de $0,64,0,53$, y 0,60 veces la concentración alcanzada en las células transfectadas con la combinación CTCT.

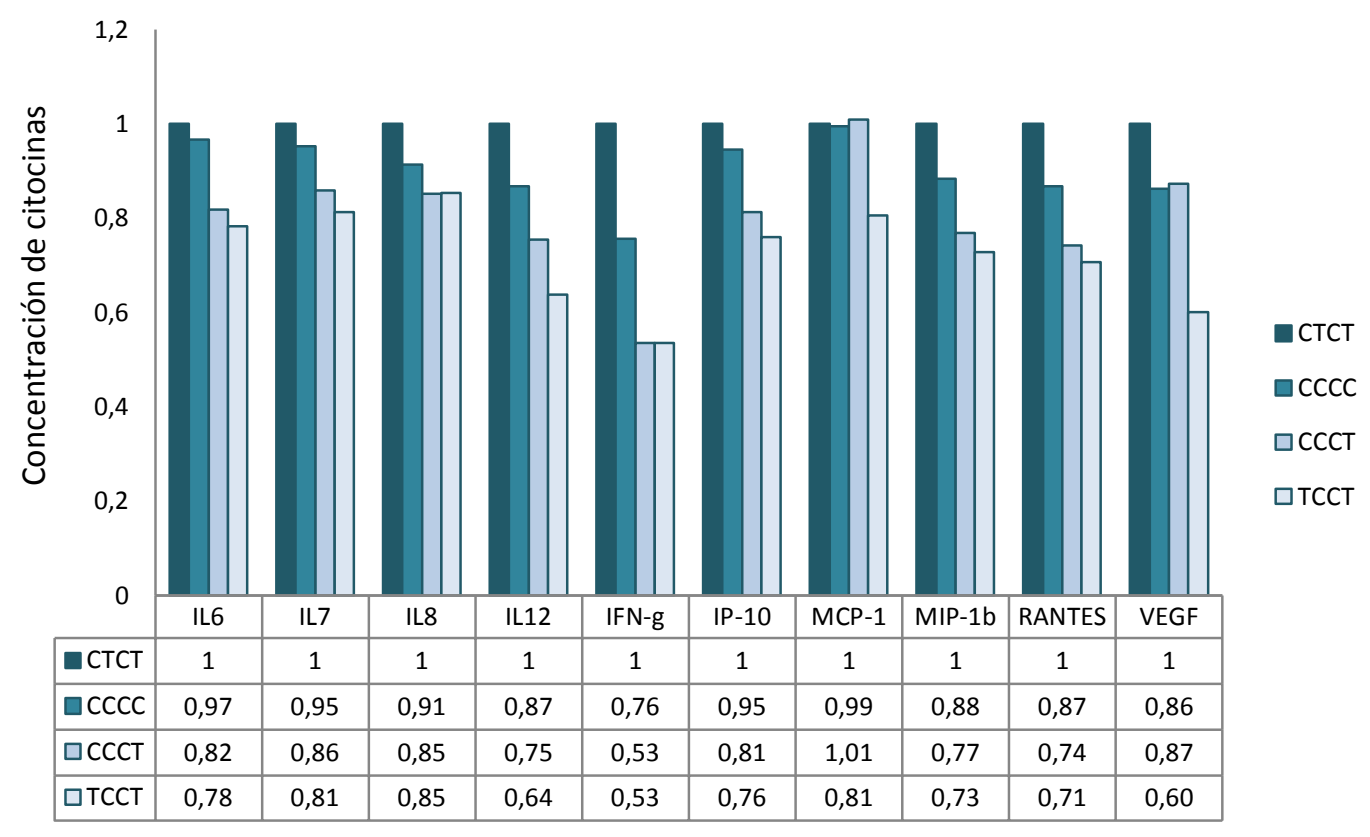

Figura 51: Influencia de la presencia de distintas combinaciones polimórficas en el promotor de PTGDR sobre el nivel de citocinas en células A549 tras $\mathbf{1 2}$ horas de cultivo. Los datos se presentan normalizados frente a la secuencia silvestre CTCT.

- A las 36 horas se confirma el aumento de la expresión de todos los haplotipos, excepto CTCT

Cuando se incrementó el tiempo de cultivo hasta las 36 horas, a las diez citocinas de mayor expresión a las 12 horas, se les sumaron la eotaxina, $\beta$-FGF e IL-1ra, que no se detectaban en el tiempo experimental anterior (Tabla 14). También incrementaron su concentración IL-5 y TNF- $\alpha$, aunque menos que el resto. De nuevo, este patrón de citocinas fue el mismo en las cuatro formas promotoras que se analizaron en este trabajo. 
Tabla 14: Patrón de expresión de citocinas a las 36 horas sin tratamiento

\begin{tabular}{|cccccc|}
\hline \multirow{2}{*}{ pg/ml } & \multicolumn{5}{c}{ Expresión de citocinas tras 36h sin tratamiento } \\
& Control & CTCT & CCCC & CCCT & TCCT \\
\hline IP-10 & $>35109,25$ & $>35109,25$ & $>35109,25$ & $>35109,25$ & $>35109,25$ \\
\hline RANTES & $>4090,75$ & $>4090,75$ & $>4090,75$ & $>4090,75$ & $>4090,75$ \\
\hline IL8 & 1620,27 & 1504,32 & 2194,19 & 1789,77 & 1793,86 \\
\hline MCP-1 & 1179,45 & 1023,58 & 1421,15 & 1431,09 & 1333,64 \\
\hline VEGF & 949,45 & 720,22 & 1152,06 & 887,87 & 992,27 \\
\hline IFN- $\boldsymbol{y}$ & 473,95 & 382,6 & 590,79 & 436,73 & 521,71 \\
\hline MIP-1 $\beta$ & 160,01 & 146,95 & 262,22 & 187,53 & 180,11 \\
\hline IL6 & 85,34 & 92,68 & 140,21 & 110,57 & 106,9 \\
\hline IL12 & 114 & 81,26 & 144,59 & 105,97 & 110,94 \\
\hline Eotaxina & 62,86 & 55,94 & 75,59 & 65,07 & 71,47 \\
\hline B-FGF & 50,99 & 49,78 & 71,04 & 66,4 & 73,01 \\
\hline IL7 & 49,46 & 38,91 & 54,1 & 40,39 & 47,93 \\
\hline IL1ra & 51,04 & 38,5 & 67,98 & 55,25 & 59,48 \\
\hline IL-5 & 19,81 & 16,72 & 27,77 & 21,13 & 20,25 \\
\hline TNF- $\alpha$ & 17,73 & 12,82 & 23,2 & 17,73 & 19,37 \\
\hline
\end{tabular}

De forma similar a lo ocurrido a las 12 horas, se constató que la transfección con los vectores de expresión de PTGDR durante 36 horas influía en la expresión de citocinas. A 36 horas, se produjo un aumento de expresión, con respecto a las células control, que se mantuvo para todas las citocinas en la variante CCCC, y para la mayoría de las citocinas en las variantes CCCT y TCCT. Por el contrario, las células transfectadas con la forma silvestre CTCT mostraron una disminución generalizada de todas las citocinas, a excepción de la IL-6, en comparación con las células control.

Comparando con los datos de cada una de las variantes a las 12 horas, la mayoría de las citocinas analizadas aumentaron su concentración con el tiempo, a excepción de la proteína quimioatrayente de monocitos 1 (MCP-1), que mostró una 
relación de concentración a 36 horas frente la concentración a 12 horas, de 0,56, 0,78, 0,77 y 0,91 para CTCT, CCCC, CCCT y TCCT respectivamente, y de 0,72 para las células control. El resto de citocinas aumentaron entre los dos tiempos experimentales en todas las variantes aunque no en todas en la misma magnitud.

- A las 36 horas, los niveles más bajos de citocinas se observan en el haplotipo CTCT, y los más altos en CCCC

Igual que ocurría a las 12 horas, tras 36 horas de cultivo también se observaron diferencias en cuanto la concentración de citocinas, dependiendo de la variante del promotor de PTGDR presente en las células. Sin embargo, cuando se dejó el cultivo celular durante 36 horas, fueron las células transfectadas con la variante CTCT las que mostraron una concentración menor en todas las citocinas de manera sistemática (Figura 52). Las formas haplotípicas no silvestres exhibieron concentraciones mayores de todas las citocinas, siendo en la variante CCCC en la que se observan los niveles más altos en prácticamente todos los casos, a excepción de MCP-1 y B-FGF. 


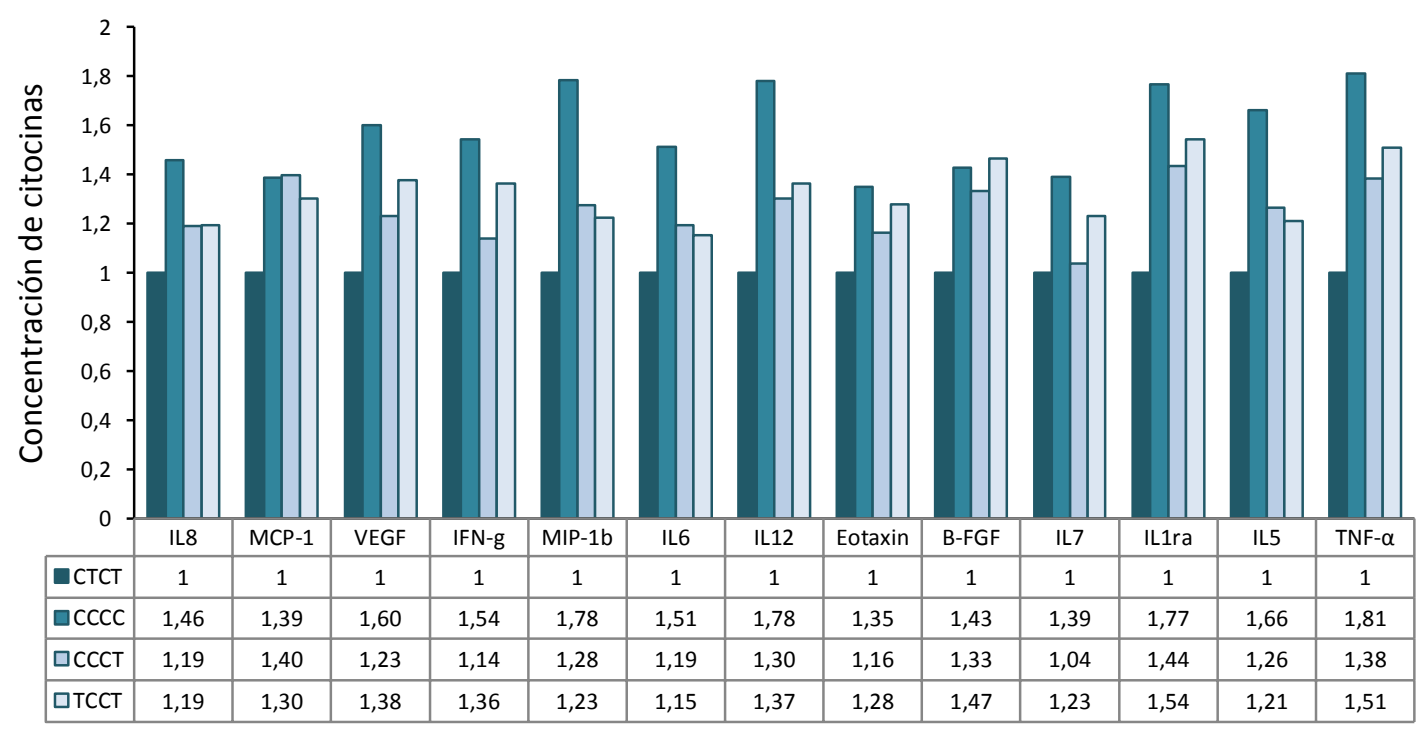

Figura 52: Influencia de la presencia de distintas combinaciones polimórficas en el promotor de PTGDR en el nivel de citocinas en células A549 tras $\mathbf{3 6}$ horas de cultivo. Los datos se presentan normalizados frente a la secuencia silvestre CTCT.

\subsubsection{La dexametasona produce una variación de la expresión de las citocinas en las}

\section{células control}

Como en los experimentos anteriores, a la hora de analizar los efectos provocados por el tratamiento con la dexametasona, se consideró como situación basal la obtenida tras someter a las células al vehículo del corticoide, el etanol. De este modo, se descarta el efecto que pudiese tener el etanol en la secreción de las distintas citocinas.

- Tras 12 horas de tratamiento se produce una disminución generalizada de la expresión de las citocinas en las células control, a excepción de IL-12 y VEGF, que aumentan

El tratamiento con dexametasona durante 12 horas provocó, en las células control, la disminución en los niveles de IL-6, IL-8, IP-10, MCP-1, MIP-1b y RANTES, en 
comparación con los niveles mostrados con etanol. El descenso más importante se observó en IP-10, ya que las células con etanol contaban con una concentración de $2457 \mathrm{pg} / \mathrm{ml}$, que cuando se trataron con dexametasona mostraron un valor de 1109,9 $\mathrm{pg} / \mathrm{ml}$. A IP-10 le siguieron en orden de disminución, MCP-1, IL-8 y RANTES que mostraron una diferencia de $1081,45 \mathrm{pg} / \mathrm{ml}, 616,77 \mathrm{pg} / \mathrm{ml}$ y $256,45 \mathrm{pg} / \mathrm{ml}$ menos con dexametasona que con etanol. La disminución en el resto de citocinas en las células control no fue tan acusada, con una diferencia de $18,91 \mathrm{pg} / \mathrm{ml}$ para IL-6 y de 1,58 $\mathrm{pg} / \mathrm{ml}$ para MIP-1b.

Por el contrario, tras el tratamiento con dexametasona en las células control, la IL-12 pasó de 47,45 pg/ml en etanol a 74,41 pg/ml con el corticoide, aumentando por tanto en 26,96 pg/ml. También aumentó VEFG, con $247,5 \mathrm{pg} / \mathrm{ml}$ más con dexametasona que con etanol.

La citocina IL-7 permaneció inalterada.

- A las 36 horas continúa la disminución generalizada de citocinas en las células control tratadas con dexametasona, con la excepción de IL-7, IL-12, VEGF y MIP-1b

Cuando se aumentó la duración de tratamiento hasta las 36 horas en las células control, se produjo una disminución en los niveles de IP-10, RANTES (por dato inferido de fluorescencia), IL-8, MCP-1, IFN- $\gamma$, IL-6, B-FGF, eotaxina, IL-1ra, IL-5 y TNF- $\alpha$, en orden según la magnitud de la disminución.

En contraposición, las citocinas IL-7, IL-12 y VEGF aumentaron sus niveles en $12,15 \mathrm{pg} / \mathrm{ml}, 107,63 \mathrm{pg} / \mathrm{ml}$ y $987,62 \mathrm{pg} / \mathrm{ml}$, respectivamente. Además, MIP-1b, que 
mostraba una disminución a las 12 horas, tras 36 horas de tratamiento con dexametasona aumentó en $120,46 \mathrm{pg} / \mathrm{ml}$ con respecto al etanol.

\subsubsection{La dexametasona ejerce efectos diferentes según la variante transfectada. Las} mayores diferencias a las 12 horas se observan en IP-10, RANTES, MIP-1b, IL-12, VEGF, $\underline{I L-6 \text { e IL-8 }}$

- Tras 12 horas de tratamiento, la dexametasona reduce los niveles de IP-10, RANTES en CTCT y CCCT, pero los aumenta en CCCC y TCCT

Se han observado diferencias importantes en la respuesta al tratamiento de las variantes CTCT, CCCC, CCCT y TCCT, respecto a las células control, y entre ellas.

En el caso de IP-10 (Figura 53), las células control tratadas con dexametasona presentaron una disminución de la concentración con respecto al etanol de 1347,1 $\mathrm{pg} / \mathrm{ml}$. Este descenso alcanzó los $2426,77 \mathrm{pg} / \mathrm{ml}$ en las células transfectadas con la variante silvestre CTCT, pero fue mucho menor en el haplotipo CCCT, sólo de 190,1 $\mathrm{pg} / \mathrm{ml}$. Por el contrario las concentraciones obtenidas tras la incubación con dexametasona presentaron un aumento de $457,7 \mathrm{pg} / \mathrm{ml}$ y $340,21 \mathrm{pg} / \mathrm{ml}$ en los haplotipos CCCC y TCCT. Analizando los duplicados de cada muestra utilizados en este ensayo, como aproximación estadística, se obtiene una diferencia significativa (Kruskal-Wallis $p=0,01$ ) entre las cuatro variantes de PTGDR para los niveles de IP-10. Además, las diferencias entre la variable silvestre, CTCT, y el resto alcanza un poder estadístico (PE) para alfa 0,05 del $100 \%$, y la diferencia entre CCCC y TCCT del $98 \%$. 
IP-10

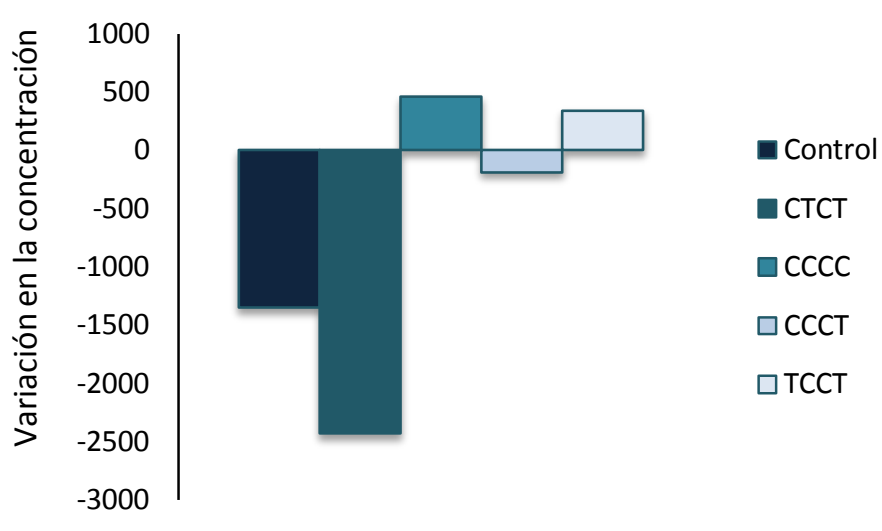

Figura 53: Efecto de la dexametasona sobre el nivel de IP-10 tras 12 horas de tratamiento. Los datos se muestran como la variación en la concentración $(\mathrm{pg} / \mathrm{ml})$ obtenida entre el tratamiento con dexametasona $2,5 \times 10^{-6} \mathrm{M}$ y el tratamiento con su vehículo, el etanol. A los datos obtenidos con el corticoide se les han restado los datos obtenidos con el etanol. El control hace referencia a las células transfectadas con el vector PCMV-XL5 sin PTGDR.

Para RANTES, se observó un patrón similar al de IP-10. Mientras que en las células control y las células con el haplotipo silvestre CTCT se produjeron disminuciones en la concentración de $256,45 \mathrm{pg} / \mathrm{ml}$ y $346,37 \mathrm{pg} / \mathrm{ml}$, respectivamente, esta disminución no fue tan elevada en la variante CCCT, 115,9pg/ml. Por el contrario, las células portadoras de los haplotipos CCCC y TCCT mostraron un aumento en la concentración de RANTES de $32,35 \mathrm{pg} / \mathrm{ml}$ y de $28,47 \mathrm{pg} / \mathrm{ml}$ respectivamente (Figura 54). Estas diferencias también alcanzaron la significación estadística (Kruskal-Wallis $p=$ 0,04). En este caso, el poder estadístico superó el $98 \%$ entre la variante silvestre y el resto, y el 91 \% en la comparación del haplotipo CCCT con CCCC y TCCT. 


\section{RANTES}

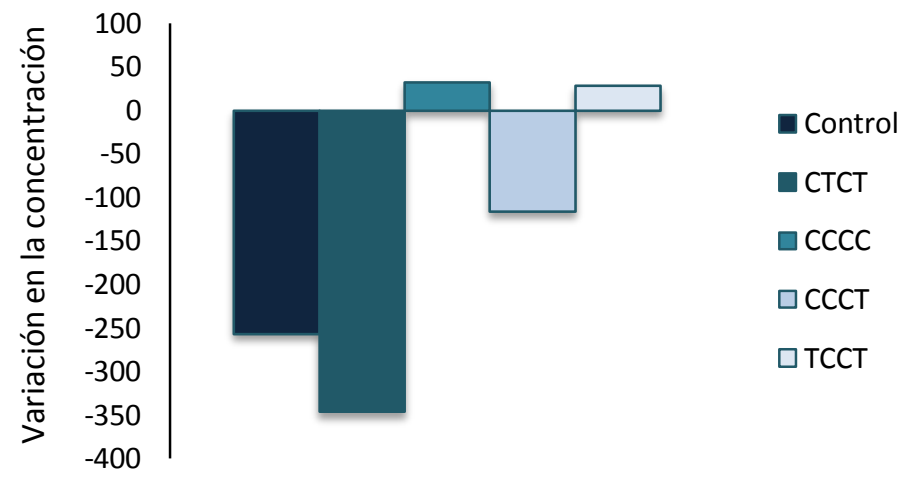

Figura 54: Efecto de la dexametasona sobre el nivel de RANTES tras 12 horas de tratamiento. Los datos se muestran como la variación en la concentración $(\mathrm{pg} / \mathrm{ml})$ obtenida entre el tratamiento con dexametasona $2,5 \times 10^{-6} \mathrm{M}$ y el tratamiento con su vehículo, el etanol. A los datos obtenidos con el corticoide se les han restado los datos obtenidos con el etanol. El control hace referencia a las células transfectadas con el vector PCMV-XL5 sin PTGDR.

- Tras 12 horas de tratamiento, la dexametasona reduce los niveles de MIP-1b en CTCT, pero los aumenta en CCCC, CCCT y TCCT

En la quimiocina CCL4 o MIP-1b, tras 12 horas de tratamiento con corticoide, se observó, para la combinación silvestre CTCT, una disminución de la concentración aún menor que en las células control, con $5,92 \mathrm{pg} / \mathrm{ml}$ menos con respecto a los datos obtenidos en etanol, mientras que en las otras tres combinaciones se produjo un incremento con valores que oscilaron entre $42,99 \mathrm{pg} / \mathrm{ml}$ en el caso de la variante CCCC, y $21,12 \mathrm{pg} / \mathrm{m}$ o $21,4 \mathrm{pg} / \mathrm{ml}$ en las variantes CCCT y TCCT respectivamente (Figura 55). 
MIP-1b

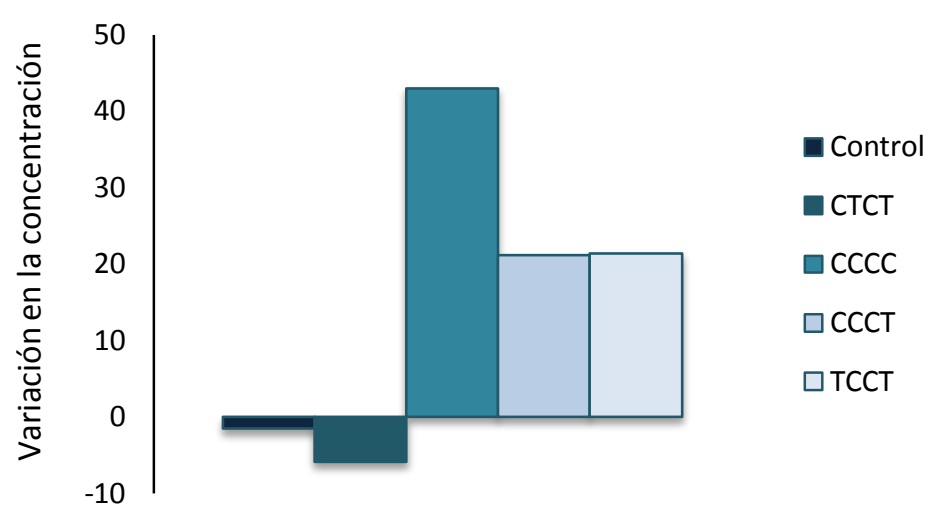

Figura 55: Efecto de la dexametasona sobre el nivel de MIP-1 $\beta$ tras 12 horas de tratamiento. Los datos se muestran como la variación en la concentración $(\mathrm{pg} / \mathrm{ml}$ ) obtenida entre el tratamiento con dexametasona $2,5 \times 10^{-6} \mathrm{M}$ y el tratamiento con su vehículo, el etanol. A los datos obtenidos con el corticoide se les han restado los datos obtenidos con el etanol. El control hace referencia a las células transfectadas con el vector PCMV-XL5 sin PTGDR.

\section{- El aumento de IL-12 y VEGF tras 12 horas de tratamiento es más elevado en CTCT y CCCC que en TCCT y CCCT}

Mientras que en la combinación silvestre CTCT y la variante CCCC se produjeron aumentos superiores a los de las células control, con aumentos de $36,3 \mathrm{pg} / \mathrm{ml}$ y 37,1 $\mathrm{pg} / \mathrm{ml}$ respectivamente para la citocina IL-12 con respecto a sus valores en etanol, la dexametasona provocó aumentos menores en TCCT, de $17,81 \mathrm{pg} / \mathrm{ml}$, e incluso disminución de la concentración en $14,71 \mathrm{pg} / \mathrm{ml}$ en las células portadoras del haplotipo CCCT (Figura 56).

Algo parecido sucedió con los niveles de VEGF. Mientras que en la combinación silvestre CTCT y la variante CCCC se obtuvieron aumentos de concentración mayores a las células control, de $278,92 \mathrm{pg} / \mathrm{ml}$ y $269,78 \mathrm{pg} / \mathrm{ml}$ respectivamente con respecto a los 
valores en etanol, la dexametasona provocó una aumentos menores en TCCT, 74,32 $\mathrm{pg} / \mathrm{ml}$, e incluso la diminución de la concentración en 84,01pg/ml en CCCT (Figura 57).

\section{IL-12}

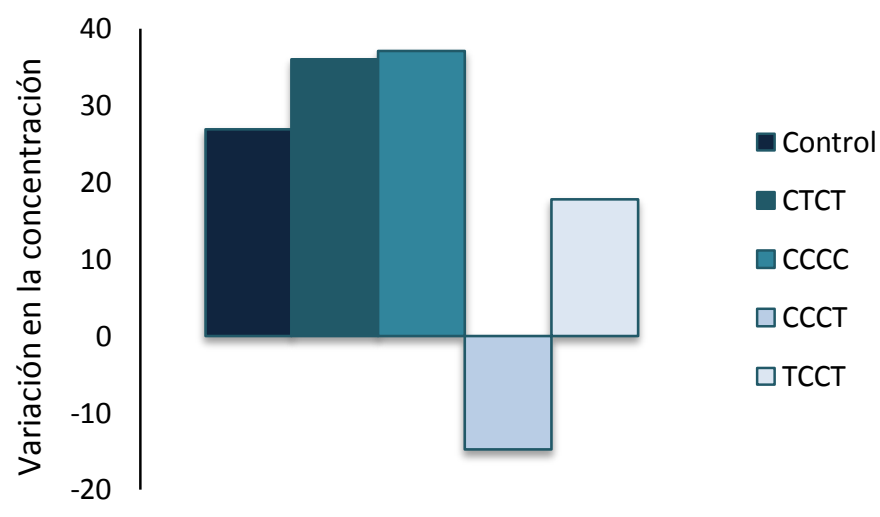

Figura 56: Efecto de la dexametasona sobre el nivel de IL-12 tras 12 horas de tratamiento. Los datos se muestran como la variación en la concentración $(\mathrm{pg} / \mathrm{ml})$ obtenida entre el tratamiento con dexametasona $2,5 \times 10^{-6} \mathrm{M}$ y el tratamiento con su vehículo, el etanol. A los datos obtenidos con el corticoide se les han restado los datos obtenidos con el etanol. El control hace referencia a las células transfectadas con el vector PCMV-XL5 sin PTGDR.

\section{VEGF}

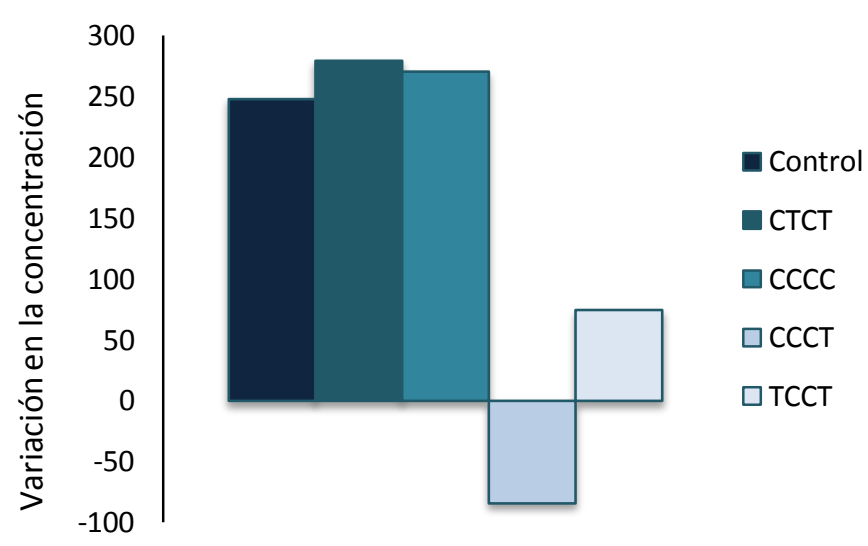

Figura 57: Efecto de la dexametasona sobre el nivel de VEGF tras 12 horas de tratamiento. Los datos se muestran como la variación en la concentración $(\mathrm{pg} / \mathrm{ml})$ obtenida entre el tratamiento con dexametasona $2,5 \times 10^{-6} \mathrm{M}$ y el tratamiento con su vehículo, el etanol. A los datos obtenidos con el corticoide se les han restado los datos obtenidos con el etanol. El control hace referencia a las células transfectadas con el vector PCMV-XL5 sin PTGDR. 
- La disminución de la concentración de IL-6 e IL-8 tras 12 horas de tratamiento con dexametasona es más evidente en CTCT que las otras variantes haplotípicas

La disminución de concentración observada en la variante CTCT para las interleucinas IL-6 e IL-8 fue superior a las células control. Sin embargo, las células portadoras de los haplotipos mutados CCCC, CCCT y TCCT mostraron una disminución menos acusada tras el tratamiento con dexametasona con respecto al tratamiento con etanol (Figuras 58 y 59). En ambos casos, la aproximación estadística realizada mostró diferencias significativas entre las variables. En el caso de la IL-6 se obtuvo una p de Kruskal-Wallis de 0,01 y un poder estadístico superior al $99 \%$ en todas las comparaciones excepto al comparar CCCC y TCCT que sólo alcanzó el 65 \%. En el caso de IL-8, se obtuvo una $p$ de 0,008 y el poder estadístico fue del $100 \%$ en todas las comparaciones.

IL-6

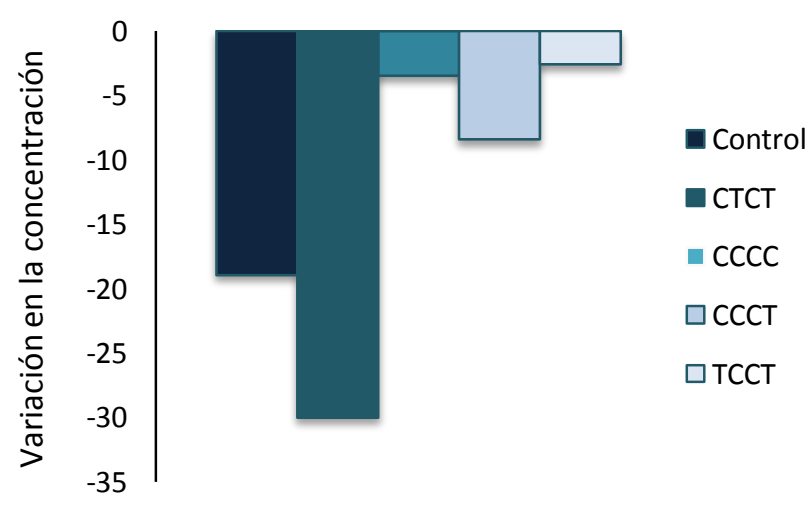

Figura 58: Efecto de la dexametasona sobre el nivel de IL-6 tras 12 horas de tratamiento. Los datos se muestran como la variación en la concentración $(\mathrm{pg} / \mathrm{ml})$ obtenida entre el tratamiento con dexametasona $2,5 \times 10^{-6} \mathrm{M}$ y el tratamiento con su vehículo, el etanol. A los datos obtenidos con el corticoide se les han restado los datos obtenidos con el etanol. El control hace referencia a las células transfectadas con el vector PCMV-XL5 sin PTGDR. 
IL-8

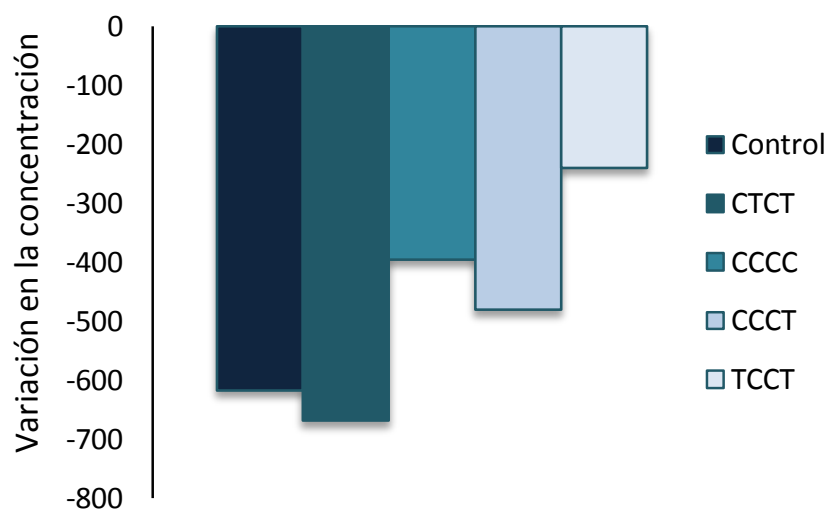

Figura 59: Efecto de la dexametasona sobre el nivel de IL-8 tras 12 horas de tratamiento. Los datos se muestran como la variación en la concentración $(\mathrm{pg} / \mathrm{ml})$ obtenida entre el tratamiento con dexametasona $2,5 \times 10^{-6} \mathrm{M}$ y el tratamiento con su vehículo, el etanol. A los datos obtenidos con el corticoide se les han restado los datos obtenidos con el etanol. El control hace referencia a las células transfectadas con el vector PCMV-XL5 sin PTGDR.

\subsubsection{El tratamiento con dexametasona origina concentraciones diferentes de citocinas} según la variante transfectada. Las mayores diferencias a las 36 horas se observan en MCP-1, IP-10, RANTES, Eotaxina e IFN-p

- Tras 36 horas de tratamiento, la dexametasona reduce los niveles de MCP-1 en CTCT, pero los aumenta en CCCC, CCCT y TCCT

Aunque en las células con el haplotipo silvestre CTCT la disminución provocada por el tratamiento con dexametasona no alcanzó la observada en las células control, se comprobaron concentraciones de $131,14 \mathrm{pg} / \mathrm{ml}$ menos que en etanol. Sin embargo, en el resto de variantes se produjeron elevaciones en el nivel de esta citocina (Figura 60). Así, la concentración de MCP-1 para CCC, CCCT y TCCT aumentó en 157,69; 276,28 y $247,98 \mathrm{pg} / \mathrm{ml}$ respectivamente. 
MCP-1

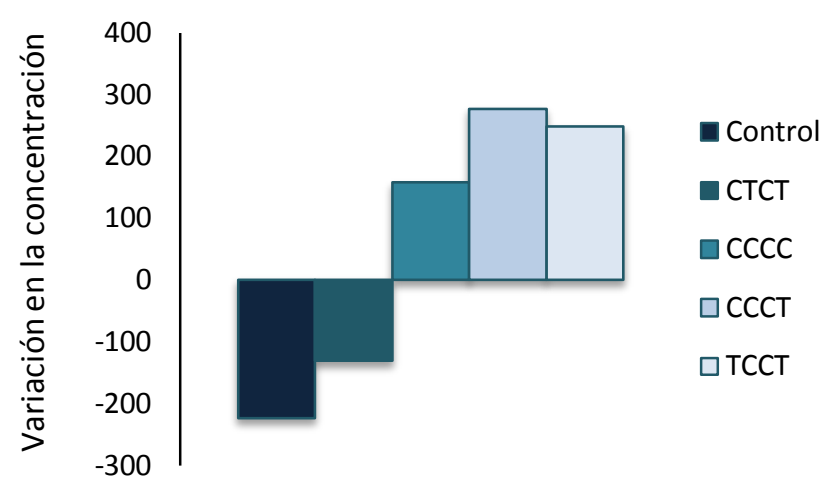

Figura 60: Efecto de la dexametasona sobre el nivel de MCP-1 tras 36 horas de tratamiento. Los datos se muestran como la variación en la concentración $(\mathrm{pg} / \mathrm{ml}$ ) obtenida entre el tratamiento con dexametasona $2,5 \times 10^{-6} \mathrm{M}$ y el tratamiento con su vehículo, el etanol. A los datos obtenidos con el corticoide se les han restado los datos obtenidos con el etanol. El control hace referencia a las células transfectadas con el vector PCMV-XL5 sin PTGDR.

\section{- Tras 36 horas de tratamiento, la dexametasona provoca distinto grado de reducción en los niveles de IP-10 y RANTES en CTCT, CCCC, CCCT y TCCT.}

En todos los ensayos realizados a las 36 horas, las concentraciones de IP-10 y RANTES fueron tan elevadas que sobrepasaban el límite de linealidad de la técnica, por lo que no se pudieron extraer los datos reales de sus concentraciones. Sin embargo, mediante la observación del dato bruto de fluorescencia obtenido en cada caso, se pudo identificar el patrón de comportamiento.

Analizando los datos de fluorescencia de IP-10, parecen indicar una disminución de los niveles en las células control y en las variantes CTCT, CCCC y CCCT tras el tratamiento con el corticoide, mientras que en el caso de la variante TCCT indicaría un aumento de la concentración. 
Por otra parte, los datos de fluorescencia de RANTES, indican una disminución de la concentración de las células control y un aumento en todas las variantes promotoras de PTGDR con mayores niveles en TCCT.

- Tras 36 horas de tratamiento con dexametasona se reducen los niveles de eotaxina en CTCT, pero aumentan en CCCC, CCCT y TCCT

Aunque a las 12 horas no se alcanzaban concentraciones detectables, a las 36 horas se produjo un aumento de la concentración de eotaxina en todas las variables. Esto hizo posible evaluar el efecto que sobre su concentración tiene el tratamiento con dexametasona a este tiempo (Figura 61). En las células transfectadas con la variante silvestre CTCT se observó una disminución de la concentración de eotaxina entre la dexametasona y el etanol de 4,56 pg/ml, muy lejos de la medida en las células control $(20,59 \mathrm{pg} / \mathrm{ml})$. Por el contrario, en las células transfectadas con las otras tres variantes, se produjeron aumentos de la concentración de eotaxina, desde 4,91 pg/ml en la combinación CCCC o de $8,3 \mathrm{pg} / \mathrm{ml}$ en la combinación CCCT, hasta 33,03 pg/ml en la variante TCCT.

- Tras 36 horas de tratamiento con dexametasona se reducen los niveles de INF- $\nu$ en las células control, pero aumentan en las cuatro variantes promotoras de PTGDR

Se comprobó una disminución de los niveles de INF- $\gamma$ de 122,92pg/ml tras 36 horas de tratamiento con dexametasona en las células control con respecto a los valores obtenidos en etanol (Figura 62). En las células portadoras de los vectores de expresión de PTGDR, el efecto fue el contrario, observándose incrementos de concentración en los cuatro haplotipos analizados. Además, se comprobó que las 
variantes mutadas mostraron aumentos mayores que los de la variante silvestre. Así, mientras en el haplotipo CTCT el incremento fue de $18,28 \mathrm{pg} / \mathrm{ml}$, en CCCC, CCCT y TCCT alcanzaron los $70,74 \mathrm{pg} / \mathrm{ml}, 80,07 \mathrm{pg} / \mathrm{ml}$ y $161,31 \mathrm{pg} / \mathrm{ml}$ respectivamente.

\section{Eotaxina}

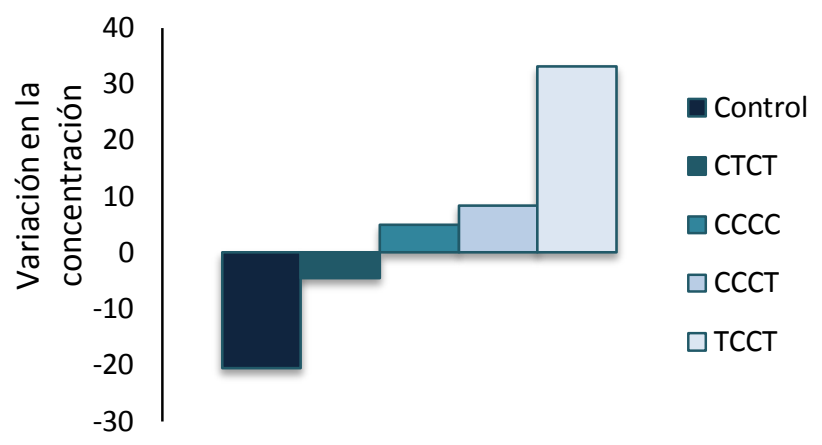

Figura 61: Efecto de la dexametasona sobre el nivel de Eotaxina tras $\mathbf{3 6}$ horas de tratamiento. Los datos se muestran como la variación en la concentración $(\mathrm{pg} / \mathrm{ml}$ ) obtenida entre el tratamiento con dexametasona $2,5 \times 10^{-6} \mathrm{M}$ y el tratamiento con su vehículo, el etanol. A los datos obtenidos con el corticoide se les han restado los datos obtenidos con el etanol. El control hace referencia a las células transfectadas con el vector PCMV-XL5 sin PTGDR.

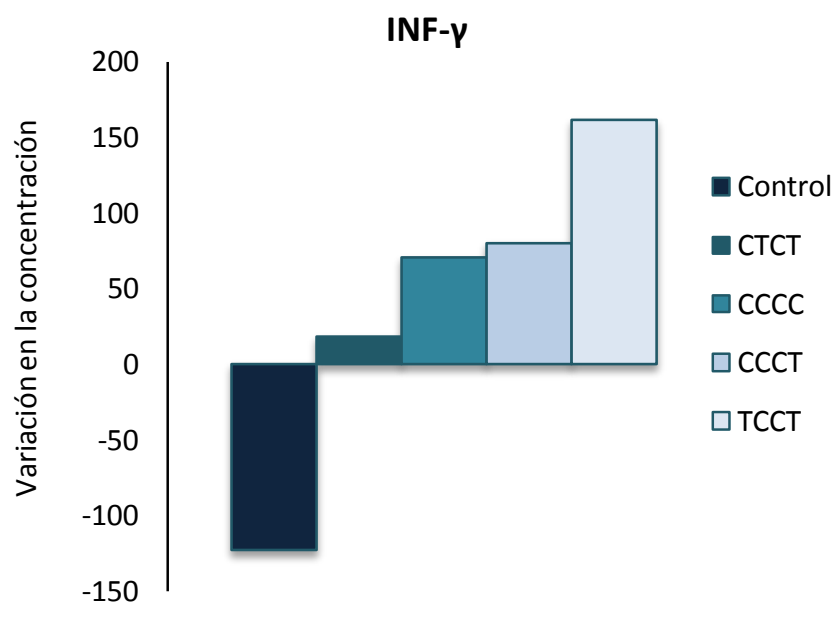

Figura 62: Efecto de la dexametasona sobre el nivel INF- $\gamma$ tras 36 horas de tratamiento. Los datos se muestran como la variación en la concentración $(\mathrm{pg} / \mathrm{ml})$ obtenida entre el tratamiento con dexametasona $2,5 \times 10^{-6} \mathrm{M}$ y el tratamiento con su vehículo, el etanol. A los datos obtenidos con el corticoide se les han restado los datos obtenidos con el etanol. El control hace referencia a las células transfectadas con el vector PCMV-XL5 sin PTGDR. 
- Tras 36 horas de tratamiento, la dexametasona provoca incrementos de las concentraciones de MIP-1b, VEGF e IL-12 superiores en las variantes de PTGDR respecto los de las células control, aunque en distinto grado según los haplotipos

En el caso de las citocinas MIP-1b y VEGF se observaron aumentos de concentración superiores a los mostrados por las células control tras el tratamiento con dexametasona durante 36 horas en las cuatro variantes polimórficas del promotor de PTGDR (Figuras 63 y 64). Comparando los cuatro haplotipos, las células portadoras del haplotipo silvestre CTCT mostraron incrementos superiores a las de las otras variantes, mientras que la variante CCCT fue la que presentó los incrementos más moderados.

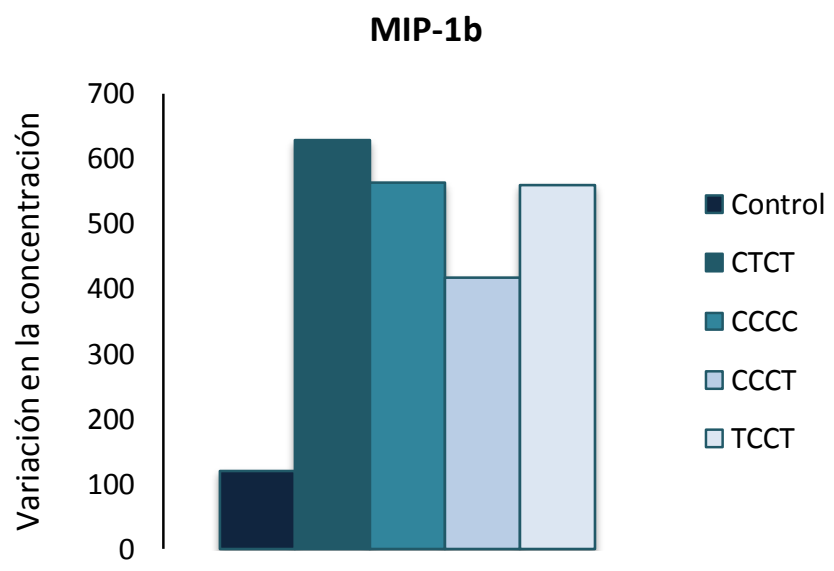

Figura 63: Efecto de la dexametasona sobre el nivel de MIP-1b tras 36 horas de tratamiento. Los datos se muestran como la variación en la concentración $(\mathrm{pg} / \mathrm{ml})$ obtenida entre el tratamiento con dexametasona $2,5 \times 10^{-6} \mathrm{M}$ y el tratamiento con su vehículo, el etanol. A los datos obtenidos con el corticoide se les han restado los datos obtenidos con el etanol. El control hace referencia a las células transfectadas con el vector PCMV-XL5 sin PTGDR. 


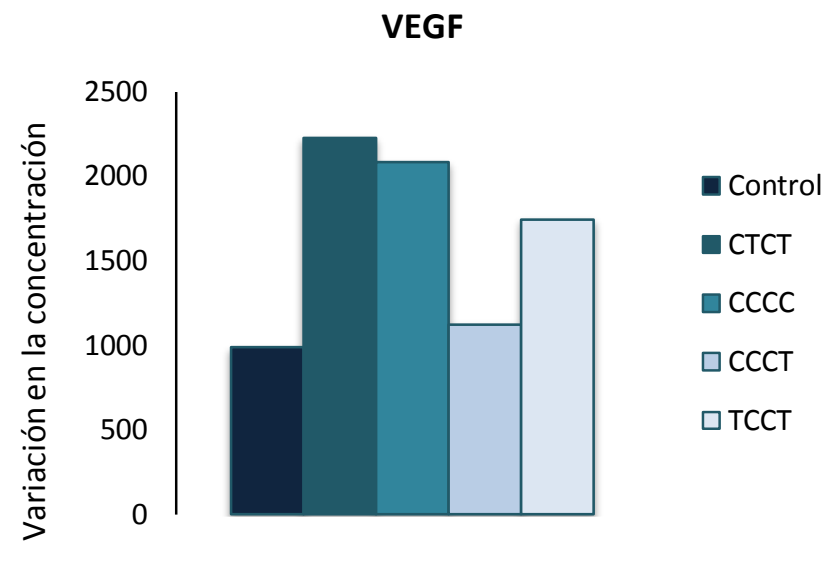

Figura 64: Efecto de la dexametasona sobre el nivel de VEGF tras 36 horas de tratamiento. Los datos se muestran como la variación en la concentración $(\mathrm{pg} / \mathrm{ml})$ obtenida entre el tratamiento con dexametasona $2,5 \times 10^{-6} \mathrm{M}$ y el tratamiento con su vehículo, el etanol. A los datos obtenidos con el corticoide se les han restado los datos obtenidos con el etanol. El control hace referencia a las células transfectadas con el vector PCMV-XL5 sin PTGDR.

Los datos obtenidos de los niveles IL-12 muestran un aumento mayor en las células con el haplotipo TCCT, en contraposición de las células con el haplotipo CCCT que también es la que presenta el incremento más moderado en esta citocina, por debajo incluso de las células control (Figura 65).

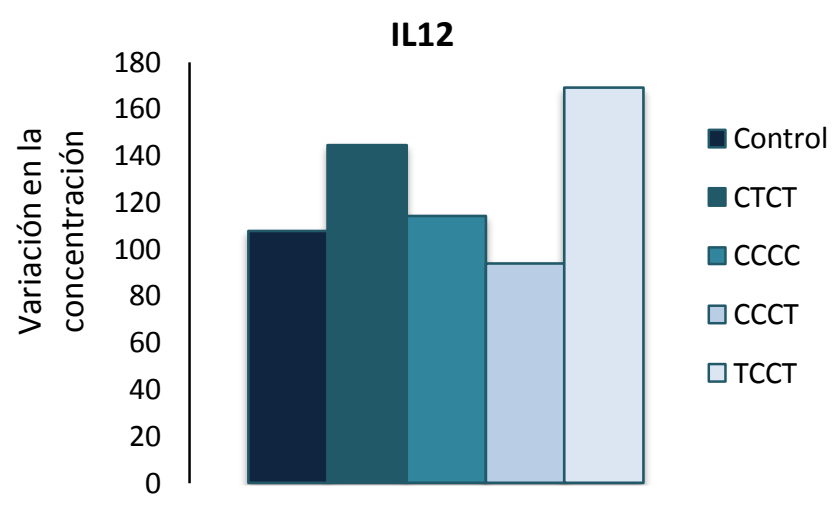

Figura 65: Efecto de la dexametasona sobre el nivel IL-12 tras 36 horas de tratamiento. LoS datos se muestran como la variación en la concentración $(\mathrm{pg} / \mathrm{ml})$ obtenida entre el tratamiento con dexametasona $2,5 \times 10^{-6} \mathrm{M}$ y el tratamiento con su vehículo, el etanol. A los datos obtenidos con el corticoide se les han restado los datos obtenidos con el etanol. El control hace referencia a las células transfectadas con el vector PCMV-XL5 sin PTGDR. 
- Tras 36 horas de tratamiento, la dexametasona disminuye los niveles de IL-6 e IL8, aunque en distinto grado según las variantes

Por último, los datos obtenidos para las diferencias de concentración entre los valores con el tratamiento con dexametasona y los valores con el tratamiento con etanol mostraron disminuciones menores en los niveles de IL-6 (Figura 66) e IL-8 (Figura 67) en las combinaciones CCCT y TCCT. Mientras que en la combinación silvestre CTCT se produjo una disminución de 94,56 pg/ml para la IL-6, y de 2240,64 $\mathrm{pg} / \mathrm{ml}$ para la IL-8, el cambio fue menor en las variantes CCCT y TCCT. Las diferencias observadas en el caso de IL-6 alcanzaron significación estadística (Kruskal-Wallis p = 0,009) con un poder estadístico superior al $98 \%$ en todas las comparaciones excepto entre los haplotipos CTCT y CCCT que no superó el $30 \%$.

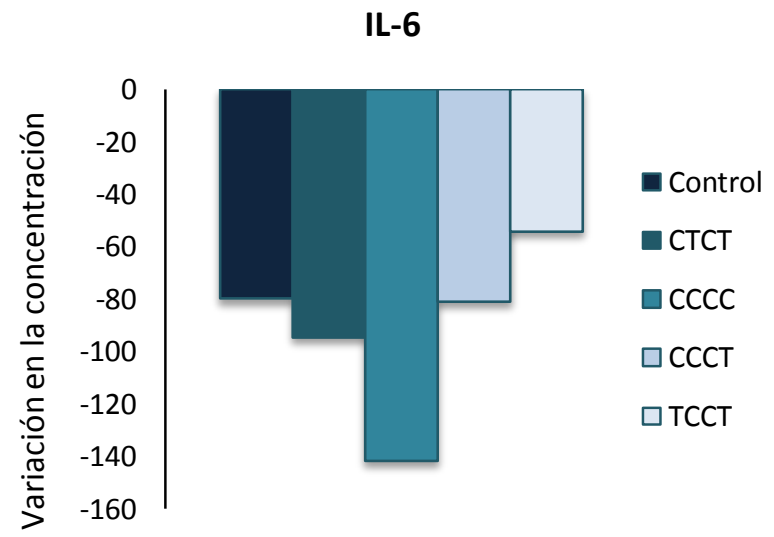

Figura 66: Efecto de la dexametasona sobre el nivel de IL-6 tras 36 horas de tratamiento. Los datos se muestran como la variación en la concentración $(\mathrm{pg} / \mathrm{ml})$ obtenida entre el tratamiento con dexametasona $2,5 \times 10^{-6} \mathrm{M}$ y el tratamiento con su vehículo, el etanol. A los datos obtenidos con el corticoide se les han restado los datos obtenidos con el etanol. El control hace referencia a las células transfectadas con el vector PCMV-XL5 sin PTGDR. 


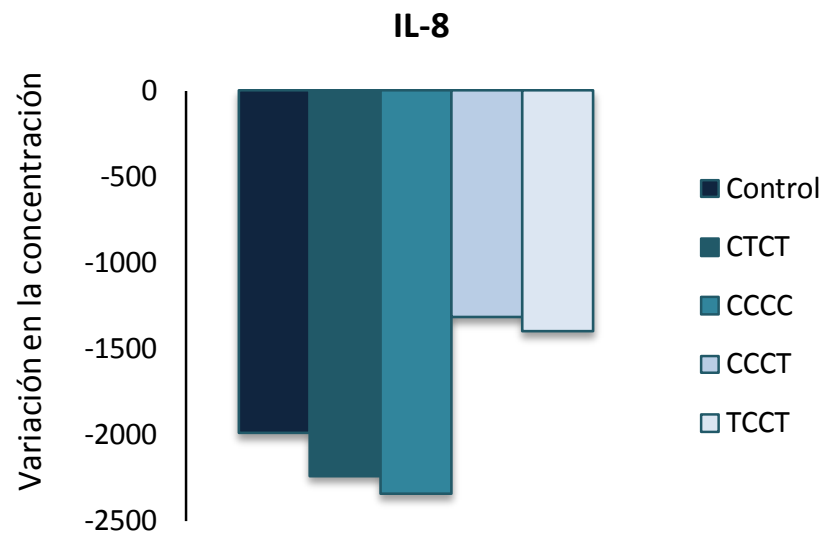

Figura 67: Efecto de la dexametasona sobre el nivel de IL-8 tras $\mathbf{3 6}$ horas de tratamiento. Los datos se muestran como la variación en la concentración $(\mathrm{pg} / \mathrm{ml}$ ) obtenida entre el tratamiento con dexametasona $2,5 \times 10^{-6} \mathrm{M}$ y el tratamiento con su vehículo, el etanol. A los datos obtenidos con el corticoide se les han restado los datos obtenidos con el etanol. El control hace referencia a las células transfectadas con el vector PCMV-XL5 sin PTGDR.

5.6. Desarrollo de un modelo múrido de asma alérgica crónica y evaluación del tratamiento con dexametasona

Para analizar el efecto de la dexametasona en un modelo animal se desarrollaron modelos múridos de asma estimulados con OVA como se ha descrito previamente. Tras analizar mediante PCR a tiempo real la expresión relativa de PTGDR, se observaron diferencias estadísticamente significativas entre las distintas condiciones experimentales (Kruskal-Wallis $p=0,013$ ): grupo control sin tratamiento, grupo control con tratamiento, grupo asmático sin tratamiento y grupo asmático con tratamiento (Figura 68). 


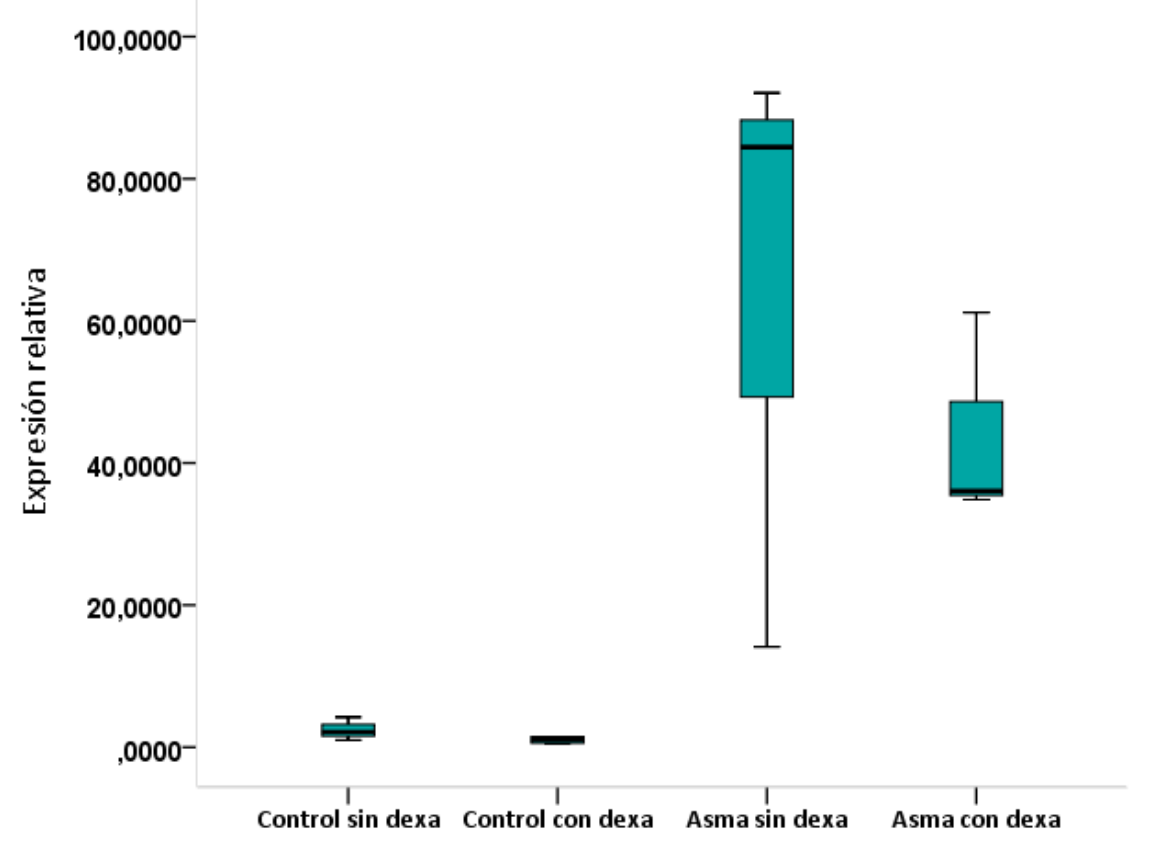

Figura 68: Análisis mediante PCR a tiempo real de la expresión de PTGDR en un modelo crónico de asma alérgica en ratón. Los resultados se muestran mediante diagramas de cajas o Box-Plot en los que se representan la mediana y los cuartiles de la expresión relativa de cada grupo frente a los niveles de expresión obtenidos en una muestra control.

La estimulación con OVA provocó un aumento generalizado de los niveles de PTGDR en los ratones de los grupos asmáticos con respecto a los de los grupos control. Al comparar los grupos sin tratamiento, el grupo control sin dexametasona presentó una mediana claramente inferior al grupo asmático sin dexametasona, con una expresión relativa respecto a una muestra control de 2,17 (rango intercuartílico, RI = $3,25)$ frente a $84,45(R I=77,96)$, respectivamente, con un poder estadístico $(P E)$ del 100 \%. Lo mismo de observó al comparar los datos obtenidos en los grupos que sí recibieron tratamiento. En este caso los controles tratados con dexametasona también presentaron una mediana inferior al grupo asmático que recibió dexametasona, 1,02 $(R I=0,89)$ frente a 36,08 (RI: 26,32), respectivamente, con un $P E=98 \%$. 
Al evaluar el efecto del tratamiento con dexametasona también se observaron diferencias entre los grupos. Tanto entre los dos grupos control como entre los dos grupos de ratones asmáticos, se comprobó que el tratamiento con dexametasona provocó una disminución de los niveles de PTGDR. Así, los ratones control tratados con dexametasona presentaron una mediana inferior, $1,02(\mathrm{RI}=0,89)$, a la mostrada por los controles no tratados, $2,17(\mathrm{RI}=3,24)$. Sin embargo el poder estadístico en este caso fue muy bajo, del 21,5\%. Finalmente, también se observó una disminución de la expresión de PTGDR en los ratones asmáticos y tratados con dexa respecto a los ratones estimulados con OVA pero que no recibieron tratamiento con el corticoide. Las medianas obtenidas fueron 36,08 $(R I=26,32)$ frente a 84,45 (RI=77,96), respectivamente, aunque en este caso el poder estadístico fue incluso menor, del 9,3 $\%$. 


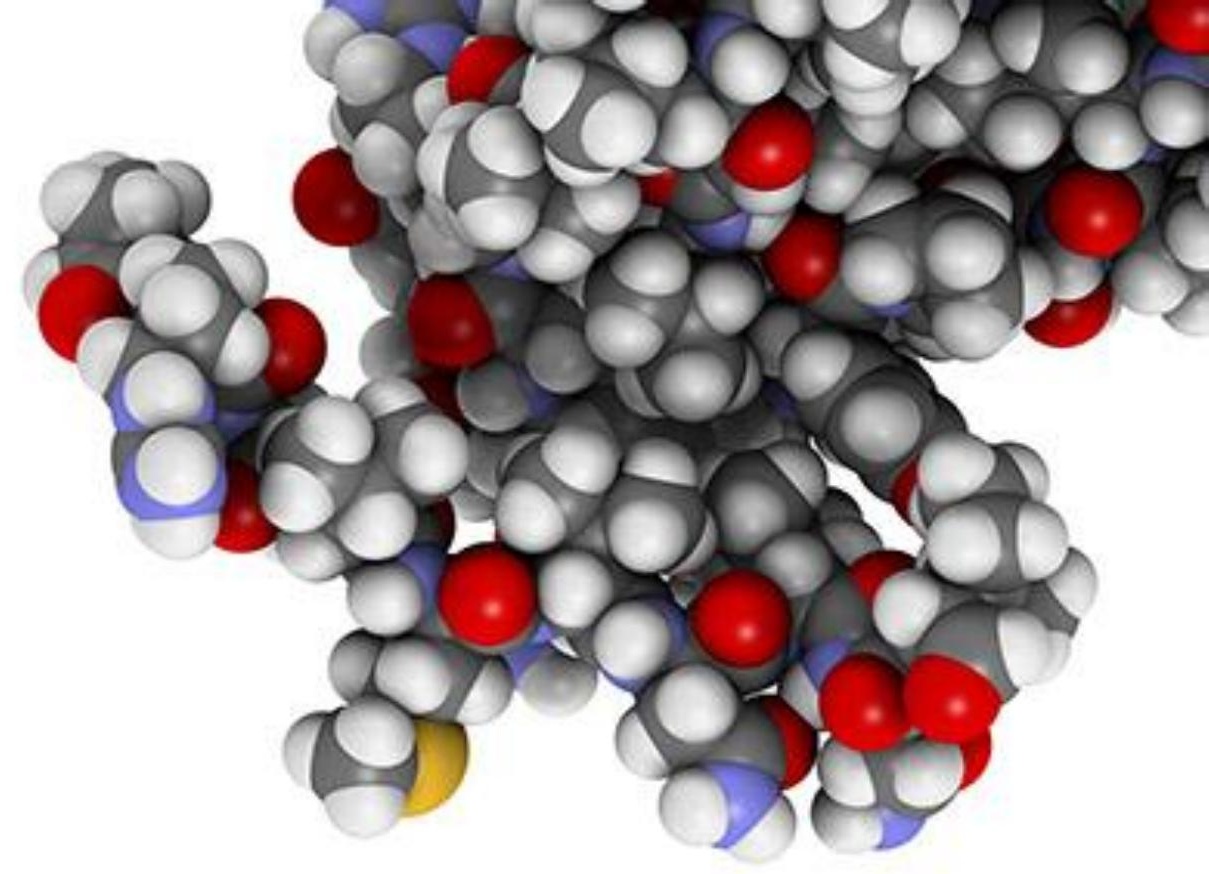

DISCVSIڤ́N 



\section{DISCUSIÓN}

\subsection{Modelo experimental en la línea celular A549}

\subsubsection{Caracterización y expresión basal de PTGDR}

Mediante el genotipado de la línea celular A549 se ha confirmado la combinación haplotípica CTTT en homocigosis para los polimorfismos -613C>T, 549T >C, $-441 \mathrm{C}>\mathrm{T}$ y $-197 \mathrm{~T}>\mathrm{C}$ en el promotor del gen del receptor de la prostaglandina $\mathrm{D}_{2}(P T G D R)$. Esta combinación no se corresponde con ninguna de las cuatro variantes promotoras consideradas en este trabajo, puesto que el cambio en $-441 \mathrm{C}>\mathrm{T}$ se mantiene conservado en las todas construcciones analizadas.

Previamente a la realización de los experimentos programados se comprobó que el grado de expresión endógena de PTGDR de las células A549 es prácticamente nulo. Esto confirma que, en el modelo propuesto, la expresión basal no supone un factor de confusión en la interpretación de los resultados obtenidos tras los ensayos de actividad promotora con gen reportero, de expresión génica con vectores de expresión, y de análisis de la concentración de citocinas en medio de cultivo. Aunque no existen datos previos de los niveles de expresión cuando está presente la combinación CTTT, este haplotipo contiene la combinación TTT (-549, -441, -613), que se asocia con una baja actividad promotora de PTGDR (197). 


\subsubsection{Metabolización de glucocorticoides}

Para comprobar la idoneidad del modelo celular propuesto para el examen de los efectos del tratamiento corticoideo, se estudió su respuesta al tratamiento con dexametasona. Para esto, se analizó un gen que codifica una de las enzimas metabolizadoras de corticoides, CYP3A5, para comprobar la respuesta celular. Esta enzima, junto CYP3A4 y CYP3A7, constituyen los principales componentes del complejo proteico citocromo $\mathrm{P} 450$, responsables de la metabolización de los glucocorticoides, entre otros muchos fármacos. Estas enzimas presentan una expresión diferencial en los distintos tejidos, siendo CYP3A5 la más abundante en el pulmón (237). Además, responde al tratamiento con diferentes corticoides (238). Diversos estudios sostienen que en las células A549 sólo se observa aumento de los niveles del mRNA de CYP3A5 y no de CYP3A4 ni CYP3A7 tras el tratamiento corticoideo, y que no observa actividad enzimática de CYP3A4 ni CYP3A7 $(239,240)$. El análisis genotípico llevado a cabo por nuestro laboratorio ha establecido que las células A549 presentan el cambio en posición 6986A>G, que da lugar a la isoforma CYP3A5*3, la más frecuente en población caucásica (241).

Se ha comprobado que se produce una inducción de la expresión de CYP3A5 tras la exposición al tratamiento corticoideo. El aumento significativo de CYP3A5 en la línea celular A549 tras el tratamiento con dexametasona indica que la línea celular propuesta responde al tratamiento con el glucocorticoide seleccionado y que, por tanto, el modelo celular establecido es válido para nuestro diseño experimental. Estos resultados refuerzan los publicados previamente en los que se observa la inducción de 
la expresión de este gen tras el tratamiento con diferentes glucocorticoides, tanto inhalados como sistémicos (242).

En conclusión, los datos obtenidos avalan la utilización de la línea celular A549 para el estudio de la implicación de la presencia de polimorfismos en el promotor de PTGDR en su expresión, en la respuesta inmune y en la respuesta a la terapia corticoidea.

\subsection{Análisis de la actividad promotora de PTGDR y su respuesta a corticoides}

En este trabajo, por primera vez, se han realizado estudios de la actividad promotora de PTGDR en cultivos celulares analizando el efecto de la presencia de las variantes génicas en las cuatro posiciones $-613,-549,-441$ y -197 . Los estudios previos sobre la influencia de los polimorfismos del promotor de PTGDR en su actividad transcripcional no incluían el polimorfismo en -613C >T (197).

\subsubsection{Influencia de los polimorfismos de PTGDR sobre su actividad promotora}

Tras 12 horas de cultivo y normalizando los datos de todas las variantes frente a la silvestre CTCT para su comparación, se encontró una actividad promotora significativamente mayor al resto en la combinación $\operatorname{CCCC}(-613,-549,-441,-197)$. Estos datos parecen indicar la necesidad de la presencia conjunta de las dos mutaciones, -549C y -197C, que están presentes en la construcción CCCC, para provocar el aumento significativo detectado en la actividad promotora. Esta mayor actividad promotora refuerza resultados previos en los que, sin tener en cuenta el polimorfismo en -613 , la combinación $\operatorname{CCC}(-549,-441,-197)$ se asociaba con una 
mayor expresión de luciferasa a las 24 horas (197). Por otra parte, se detectó una actividad significativamente menor de TCCT, es decir, parece que la presencia simultánea de los cambios -613T y -549C en una misma combinación (TCCT) provoca una disminución significativa en la actividad promotora de PTGDR tras 12 horas de cultivo.

A las 36 horas, como consecuencia de la disminución de la actividad promotora de todas las variantes excepto de la variante CTCT, que mantiene los niveles de expresión, las diferencias observadas entre la variante con el haplotipo silvestre CTCT y la variante CCCC, perdió significación, aunque permaneció la combinación CCCC como la que mostraba el dato más elevado. Por otro lado, se acentuó la diferencia de la variante silvestre con la variante CCCT, y con la variante TCCT. Por lo tanto, la presencia del cambio -549T>C tanto en solitario, como en combinación con el cambio $613 C>T$, provoca una activación promotora significativamente menor que en el resto de las variables.

En los datos aportados por Oguma y col. (197), la combinación CCT (-549, -441, -197) mostraba una actividad promotora superior a la forma silvestre TCT. Estas diferencias pueden deberse a que en este trabajo no se tenía en cuenta la presencia de polimorfismos en la posición -613. Además, el inserto que ellos utilizaban constaba de 1107 pares de bases, mientras que el nuestro sólo tiene 653 pares de bases. Al ser un inserto mayor, podrían estar influyendo otras posiciones polimórficas. 


\subsubsection{Influencia de los polimorfismos de PTGDR sobre la evolución temporal de su} $\underline{\text { actividad promotora }}$

Se ha observado una disminución del grado de activación promotora a lo largo del tiempo para las variantes haplotípicas CCCC, CCCT y TCCT, aunque no así en la variante silvestre CTCT, que mostró una actividad promotora estable, ya que a las 36 horas conservó el $100 \%$ de su actividad a las 12 horas. De forma generalizada, las variantes presentes en las combinaciones haplotípicas CCCC, CCCT y/o TCCT, podrían provocar una dificultad para mantener los niveles de actividad promotora iniciales.

No existen estudios anteriores que asocien la presencia de estos $u$ otros haplotipos en el promotor de PTGDR con variaciones de la actividad promotora a lo largo del tiempo. Sin embargo, estos datos sugieren que estos cambios nucleotídicos en la región promotora podrían estar afectando a la estabilidad de su interacción, bien con factores de transcripción o bien con otros elementos implicados en el proceso transcripcional, dependientes del tiempo.

\subsubsection{Efecto del tratamiento con glucocorticoides sobre la actividad promotora de} $\underline{\text { PTGDR }}$

Aunque se han identificado polimorfismos en distintos genes que modifican la respuesta a la acción de los corticoides como tratamiento en la enfermedad asmática (243-249), en este estudio se analiza por primera vez el efecto de la presencia de distintas combinaciones haplotípicas en el promotor del gen PTGDR sobre su respuesta al tratamiento corticoideo. 
Los datos obtenidos tras la administración de dexametasona al cultivo celular, mostraron un incremento global de la actividad promotora, independientemente de la combinación haplotípica presente en las células. Este incremento fue mayor a las 12 horas que a las 36 horas, aunque en ambos casos se mantuvo la significación estadística respecto a los datos obtenidos en etanol. Podemos concluir que el efecto máximo de la dexametasona se detecta a las 12 horas del inicio de tratamiento, y que, aunque en menor grado, los efectos se prolongan como mínimo hasta las 36 horas, tal como cabría esperar, puesto que la dexametasona cuenta con una vida media en los tejidos de 36-54 horas (vida media plasmática alrededor de 190 minutos).

\subsubsection{Influencia de los polimorfismos de PTGDR sobre su respuesta a glucocorticoides a} nivel de actividad promotora

Aunque todas las variantes responden al tratamiento aumentando su actividad promotora, se observó un mayor grado de respuesta en la variante silvestre CTCT. Esto se traduce en que, aunque la variante con mayor expresión basal es la CCCC, tras el tratamiento con dexametasona, es la variante silvestre CTCT la que presenta un mayor aumento de la expresión, disminuyendo su diferencia de actividad con los niveles de actividad de CCCC a las 12 horas, y sobrepasándolos a las 36 horas. Estos datos indican que la combinación con las posiciones $-613,-549,-441$ y -197 conservadas tiene una mayor capacidad de respuesta al tratamiento con dexametasona.

Por otra parte, el haplotipo TCCT, que ya contaba con una menor actividad promotora en condición basal, también es la que menor actividad presentó tras la administración de dexametasona, tanto a 12 horas como a 36 horas, con diferencias significativas frente a CTCT en ambos tiempos. 


\subsection{Análisis de la expresión de PTGDR y su respuesta a corticoides}

La actividad transcripcional de un gen no viene determinada únicamente por su secuencia promotora, sino que pueden existir elementos situados en otras regiones implicados en la regulación de su expresión. Por este motivo, se han completado los ensayos de actividad promotora realizados, con el estudio del comportamiento de las cuatro variantes haplotípicas de PTGDR en presencia de la secuencia codificante completa del gen.

\subsubsection{Influencia de los polimorfismos de PTGDR sobre su expresión}

Se ha observado un aumento de la expresión de PTGDR en las células transfectadas con los vectores portadores de la secuencia codificante completa del gen, que ha sido mayor tras 36 horas de cultivo que tras 12 horas de cultivo, a diferencia de lo observado en los ensayos de actividad promotora, en los que ésta sufría una disminución al prolongar el tiempo experimental. Esta divergencia en los resultados podría explicarse por la presencia de elementos reguladores en la secuencia codificante del gen, necesarios para una correcta transcripción génica o para el mantenimiento de la estabilidad de la unión de la maquinaria de transcripción, y que estarían ausentes en los ensayos de luciferasa. Ya se ha demostrado la presencia de sitios de unión de factores de transcripción en exones de distintos genes (250-252) y de secuencias reguladoras exónicas $(253,254)$ que complementan la acción promotora y su interacción con la RNA polimerasa II (255). Esto podría estar sucediendo también en el control de la expresión génica del gen PTGDR. 
En cuanto a las diferencias en el nivel de expresión dependiendo de la variante promotora presente, aunque no se lograra alcanzar la significación estadística, se ha observado que la combinación haplotípica TCCT tiene una menor expresión de PTGDR que el resto, tanto a las 12 como a las 36 horas. Esta variante también mostraba los menores niveles de actividad promotora en los ensayos de luciferasa, lo que sugiere que cuando se asocian las dos mutaciones, -613T y -549C, (TCCT) se produciría una menor actividad promotora, que conlleva una menor expresión de PTGDR. De nuevo, la presencia de ciertas variantes génicas en la región promotora de PTGDR podría dar lugar a diferencias en los niveles de expresión de este gen que pudieran estar relacionadas con una mayor probabilidad de desarrollo de la enfermedad alérgica.

En los otros tres haplotipos, CTCT, CCCC y CCCT, se observa un comportamiento variable. A las 12 horas, es la variante CCCT la que muestra una mayor expresión, por encima de CCCC y de la variante silvestre CTCT. Sin embargo, a las 36 horas, es la variante CCCC la que muestra una expresión mayor. Las variantes CCCC y CCCT tienen una expresión que supera a la de la variante silvestre CTCT en ambos tiempos, lo que parece indicar que la combinación de polimorfismos podría tener un efecto en la respuesta temporal.

Los datos aportados por los ensayos de actividad promotora y expresión génica realizados en este trabajo evidencian diferencias entre las cuatro combinaciones haplotípicas de PTGDR, que podrían estar relacionadas con los diferentes fenotipos observados en los pacientes y/o con la susceptibilidad de los individuos portadores al padecimiento de enfermedades alérgicas. De hecho, existen varios estudios publicados que relacionan estos polimorfismos con el asma. En 2004, Oguma y col. establecían 
una asociación entre el cambio -549T>C con el asma (197), y más tarde, Sanz y col., hicieron lo propio con el polimorfismo -197T>C, demostrando además, una mayor presencia del haplotipo CCC $(-549,-441,-197)$ en pacientes asmáticos y, en especial, en el asma alérgica (198). Isidoro-García y col. relacionaron posteriormente el polimorfismo $-613 C>T$ en $P T G D R$ con la alergia, principalmente al polen y a los ácaros (203). Estudios previos realizados en nuestro laboratorio indican que la presencia del alelo $\mathrm{T}$ en esta posición se asocia con el asma atópica, en particular con la sensibilización a pólenes, ácaros o a ambos, y se ha detectado una mayor frecuencia de la combinación TCCT $(-613,-549,-441,-197)$ en los pacientes asmáticos con sensibilización simultánea a ácaros y pólenes en comparación con el grupo control.

Sin embargo, otros trabajos no han podido replicar la asociación entre los polimorfismos de PTGDR y la enfermedad alérgica $(204-206,256)$. Esto podría deberse a diversos factores como las diferencias étnicas, a diferencias en los criterios de selección de pacientes y/o el tratamiento de los datos, o a la necesidad de analizar los polimorfismos de forma conjunta, en secuencias haplotípicas concretas, y no por separado y de forma individualizada. En este sentido, los resultados obtenidos en el presente trabajo apoyan esta última observación al confirmar que es necesaria la presencia conjunta de los polimorfismos $-549 \mathrm{~T}>\mathrm{C}$ y $-197 \mathrm{~T}>\mathrm{C}$ para determinar el aumento de la actividad promotora observado en los ensayos con luciferasa, así como la presencia conjunta de las variantes en $-613 \mathrm{C}>\mathrm{T}$ y $-549 \mathrm{~T}>\mathrm{C}$ para determinar una disminución de dicha actividad.

Por otro lado, según San Segundo y col. (manuscrito en preparación), se pueden observar niveles más elevados de expresión de PTGDR en sangre periférica en 
los pacientes alérgicos. Teniendo en cuenta que el haplotipo silvestre CTCT es el más frecuente en la población control, sí se cumple que las combinaciones CCCC y CCCT presentan niveles de expresión superiores. Por tanto, el cambio -549C, de forma individual (CCCT), o en combinación con el cambio -197T (CCCC) estarían provocando mayores niveles de expresión de PTGDR que la combinación silvestre, relacionándose, así, con el grado de susceptibilidad alérgica. Esto estaría en consonancia con los estudios que relacionan los polimorfismos $-549 \mathrm{~T}>\mathrm{C}$ y $-197 \mathrm{~T}>\mathrm{C}$ con el asma alérgica $(197,198)$. Además, estudios publicados por Sanz y col. sugieren que el diplotipo CCCC CCCT es el más frecuente en los pacientes con asma (199). Sin embargo, la menor expresión de PTGDR en las células portadoras de la variante TCCT parece no coincidir con estudios que relacionan este haplotipo con los pacientes alérgicos y con el asma atópica (203).

\subsubsection{Efecto del vehículo del corticoide sobre la expresión de PTGDR}

En este trabajo se analiza por primera vez el efecto del tratamiento con dexametasona sobre la expresión de PTGDR, así como la influencia de la presencia de distintas variantes haplotípicas en su promotor sobre la respuesta al tratamiento. En primer lugar, se ha observado que la presencia de etanol, vehículo en el que va disuelta la dexametasona, provoca aumentos significativos de la expresión de PTGDR en todas las variantes y en los dos tiempos experimentales. Estos datos corroboran la necesidad de realizar el análisis de los efectos de la dexametasona referidos a los datos de su vehículo, ya que el efecto del tratamiento será un efecto combinado de ambos. Este efecto del etanol sobre la expresión génica no se observaba en los ensayos de actividad promotora, por lo que también reafirma la conveniencia de completar los 
ensayos de actividad promotora con ensayos de cuantificación de la expresión génica para tener una información lo más completa posible de los factores que puedan estar influyendo en el proceso a estudio.

Está comprobado que la presencia de etanol puede alterar el normal funcionamiento de las células, la supervivencia celular $(257,258)$, las funciones de los receptores, la homeostasis mitocondrial o las rutas celulares de transmisión de señales, o puede inducir estrés oxidativo (259). Algunos autores sostienen que, además, modifica la respuesta inflamatoria en cultivos celulares. Aunque diversas publicaciones sugieren que el etanol provoca una disminución de citocinas proinflamatorias $(260,261)$, otros estudios muestran un aumento de la expresión de citocinas inflamatorias en modelos murinos de dermatitis atópica así como una exacerbación de la reactividad alérgica, lo que estaría en consonancia con el efecto de incremento de expresión de PTGDR en las células tratadas con etanol (262-264).

En cualquier caso, para evitar cualquier sesgo en el estudio del efecto del tratamiento corticoideo se ha tenido en cuenta el posible impacto que pudiera tener el etanol en todos los ensayos realizados.

\subsubsection{Efecto del tratamiento con glucocorticoides sobre la expresión de PTGDR}

Al tratar las células con dexametasona se ha observado que se produce un patrón de respuesta alternante a lo largo del tiempo. Tras 12 horas de tratamiento se observó una disminución en los valores de expresión de PTGDR, mientras que a las 36 horas se produjo una elevación de estos valores que superaron los mostrados por las células sin corticoide a este tiempo. Esta regulación dinámica de la transcripción de 
PTGDR, podría estar provocada por distintos fenómenos implicados en la unión del receptor de glucocorticoide al genoma y en su acción sobre la expresión génica, que provocan cinéticas de regulación muy dispares (265). La mayoría de las modificaciones en la expresión génica provocadas por glucocorticoides cumplen patrones complejos en los que se alternan fases de activación y de represión (266). Así, el efecto de la dexametasona sobre la expresión de PTGDR estaría cumpliendo un patrón de respuesta tiempo-dependiente, en el que primero se produce una represión rápida pero transitoria, seguida de una fase de incremento de la expresión.

En los ensayos de actividad promotora no se evidenciaba el efecto represor a 12 horas. Una explicación podría residir en la necesidad de que estén presentes secuencias reguladoras en sentido $3^{\prime}$ del sitio de inicio de la transcripción, como ocurre, por ejemplo, con sitios de regulación localizados en secuencias exónicas del gen $B c l-2$ (267).

Estos datos refuerzan la necesidad de completar los ensayos de actividad promotora con ensayos de expresión.

\subsubsection{Influencia de los polimorfismos de PTGDR sobre su respuesta a glucocorticoides a} nivel de expresión génica

Aunque el patrón de respuesta se mantiene en todas las variantes, sí se han observado diferencias en la intensidad con que se produce esa respuesta. Como se ha comentado anteriormente, tras 12 horas de tratamiento se observó una represión de la expresión génica que fue más acusada en la variante silvestre CTCT. Del mismo modo, el aumento en los niveles de PTGDR observados tras 36 horas de tratamiento es 
más notable en la construcción tipo silvestre. El hecho de que la dexametasona provoque efectos mayores en CTCT ya ha sido observado en este trabajo mediante otra aproximación experimental completamente distinta, como es el análisis de la actividad promotora. Estos resultados parecen indicar la presencia de elementos de respuesta específicos en la variante tipo silvestre, que se pierden en los cambios polimórficos.

Por otro lado, la menor represión a las 12 horas se observó en la variante TCCT, portadora de los cambios $-613 T$ y -549C. Este haplotipo también presentó niveles más bajos de expresión de PTGDR que la variante silvestre tras 36 horas de tratamiento. La presencia de estos dos cambios polimórficos de forma conjunta, podría estar relacionada, por tanto, con una menor respuesta al tratamiento corticoideo.

La presencia conjunta de los cambios -613T y -549C (TCCT) vuelve a relacionarse con la patología asmática, ya que en este caso podría indicar que los pacientes con estas mutaciones en la región promotora de PTGDR podrían tener menor capacidad de respuesta al tratamiento. Esto tal vez pudiera estar en relación con las diferencias observadas en la clínica en la respuesta al tratamiento con corticoides entre unos pacientes y otros, de un modo similar al que relaciona el cambio -441C>T en PTGDR con la respuesta a la terapia con antagonistas del receptor de leucotrienos (213). 
6.4. Influencia de los polimorfismos en el promotor de PTGDR sobre la unión de factores de transcripción.

Se ha planteado un abordaje mediante algoritmos informáticos para la identificación de sitios de unión de factores de transcripción en la secuencia del promotor de PTGDR a estudio. Así, mediante dos bases de datos bioinformáticas, MatInspector y Transfac (Biobase), se han detectado alteraciones en la afinidad de unión de diversos de factores de transcripción en función de la presencia del nucleótido conservado o mutado en las posiciones -643 C > T, -549 T>C, -441 C >T y -197 $\mathrm{T}>\mathrm{C}$.

Según el algoritmo informático Matlnspector, la presencia del alelo silvestre citosina en la posición -613 proporciona un sitio de unión para el factor de transcripción GZF1, también conocido como ZNF336. Se trata de una proteína con dedos de $\mathrm{Zn}^{2+}$ inducida por el factor neurotrófico derivado de células gliales (GDNF, glial cell-line-derived neurotrophic factor), con capacidad para unión a ADN, y con actividad represora transcripcional (268) a través de dominios BTB/POZ (269). Además, este factor de transcripción contiene un elemento de respuesta a glucocorticoides (270), lo que podría explicar la mayor represión de la expresión de PTGDR mediada por dexametasona en las variantes con citosina en esta posición, CTCT, CCCC y CCCT, en comparación con la variante TCCT.

Cuando en esta posición, -613, aparece una timina en lugar de una citosina, sólo presente en la variante TCCT, se crean sitios posibles de interacción con SOX15, MAFB y MAFF. SOX15 aparece sobreexpresado con mayor frecuencia en casos de adenocarcinoma de pulmón, aunque está reprimido en muchos otros tipos de cáncer 
(271). MAFB y MAFF pertenecen a la misma familia Maf de factores de transcripción, que está implicada en el desarrollo, diferenciación, y funcionamiento de multitud de órganos, con efectos sobre el páncreas, el cartílago, tejido adiposos, mieloma, etc. (272). Unos niveles incrementados de MAFB se asocian con la gravedad de la enfermedad pulmonar obstructiva crónica, y un empeoramiento de la función pulmonar en fumadores (273), mediante la inhibición de la apoptosis de macrófagos (274). Por tanto, la unión de estos factores de transcripción en la variante TCCT podría tener relación con la patología asmática.

La variante silvestre CTCT es la única de las estudiadas en este trabajo que mantiene conservado el nucleótido en posición -549. Este hecho hace que sea el único haplotipo con sitios de interacción para los heterodímeros CAR/RXR y VDR/RXR, según el algoritmo MatInspector. Estos factores de transcripción son receptores para androsteno (CAR), ácido retinoico (RXR) y vitamina $D(V D R)$. Tanto la vitamina $D$ como el ácido retinoico son potentes inmunomoduladores, con un importante papel en el equilibrio entre las respuestas Th1/Th2 y en el desarrollo del asma alérgica. Ambos metabolitos estarían implicados en la diferenciación de una respuesta inmune tipo Th2 (275), que también se ha relacionado con la prostaglandina D (170). Sin embargo, se ha descrito que la vitamina $D$ provoca una disminución de citoquinas inflamatorias en los pacientes con asma, incluso podría aumentar la acción antiinflamatoria de la dexametasona cuando se utilizan de forma combinada. Además, se ha propuesto que la vitamina D podría ayudar a revertir la resistencia a corticoides promoviendo la acción de células T reguladoras secretoras de IL-10 (276). Por su parte, el ácido retinoico ha demostrado atenuar la inflamación pulmonar, y la administración de ATRA (all-trans retinoic acid) disminuye los niveles de citoquinas Th2 (277). El receptor 
nuclear CAR desempeña un papel crucial en la respuesta celular a la acción de diferentes fármacos mediante la regulación de la expresión de sus genes diana, y la regulación de la expresión de enzimas constituyentes del complejo Citocromo P450 (278). Además, se han descrito elementos de respuesta a glucocorticoides en el gen codificante del CAR (279), aumentando su expresión en presencia de dexametasona (280, 281). Esta relación entre CAR y el receptor de glucocorticoides podría estar detrás de la mayor respuesta a dexametasona observada en la variante silvestre CTCT.

Además, la presencia del alelo silvestre T en -549 proporciona un sitio de unión a NBRE (NGFI-B Response element, elemento de respuesta a NGFI-B). NGFI-B (o Nur77) modula la acción de los macrófagos, a través de la inhibición de la expresión de genes inflamatorios mediante la represión de NF-KB (282). Está descrito que la deleción del gen NUR77 provoca una polarización de monocitos y macrófagos a un estado proinflamatorio (283).

Utilizando el algoritmo bioinformático Transfac (Biobase) la variante CTCT, por mantener el nucleótido T en posición -549, cuenta con sitios de unión para factores de transcripción NFAT e ISGF-3. NFAT constituye una familia de factores de transcripción que está implicada en el desarrollo de células $T$, y en la activación de células $T$, células B y mastocitos (284). Algunos estudios sugieren que la inhibición de NFAT en las células $\mathrm{T}$ debilita el desarrollo de la repuesta inmune Th2 y previene la patología pulmonar asociada a la inflamación alérgica de las vías respiratorias (285). Por otro lado, ISGF-3, es un factor de transcripción heterotrimérico (STAT2, STAT1, IRF9) que media la regulación de los genes estimulados por interferón (286), y que responde principalmente al interferón $\alpha / \beta$, inhibidor de la producción de citocinas Th2 (287). 
Cuando, por el contrario, en la posición -549 está presente el cambio T>C, lo que ocurre en todas las variantes haplotípicas excepto en la silvestre, aparecen sitios de unión a GABP y FREAC según el algoritmo MatInspector. GABP, es un miembro de la familia de factores de transcripción Ets, que se ha relacionado con el desarrollo de timocitos y la respuesta inmune mediada por células $T$, mediante la activación del receptor de IL-7 en linfocitos T (288). También parece estar implicado en la expresión de $\beta_{2}$-integrina o CD18 y en la migración de células Th2 y neutrófilos a los sitos de inflamación (289). Por su parte, FREAC2 (FOXF2 o LUN) es un factor de transcripción altamente expresado en pulmón, que contribuye al estrés oxidativo provocado por la exposición al humo de cigarrillo (290). Este factor de transcripción provoca la activación transcripcional de sus genes diana mediante la unión a TBP y TFIIB, dos componentes del complejo de transcripción, que interaccionan a su vez con otros factores de transcripción (291). Además, hay que tener en cuenta que según el algoritmo Transfac (Biobase) el cambio polimórfico en -549 provoca la pérdida de un sitio de unión al receptor de glucocorticoide, lo que podría estar detrás de una menor respuesta a la dexametasona de las variantes CCCC, CCCT y TCCT, con respecto a las variantes silvestre CTCT.

Por último, según el algoritmo MatInspector, el cambio -197 T>C provoca la aparición de un sitio de unión a MAZ y a SRF que no está presente con el nucleótido conservado. La familia de factores de transcripción MAZ media en la respuesta inflamatoria (292) y su unión al DNA y su actividad transcripcional aumentan en respuesta a la estimulación por citoquinas (293). 
Según Transfac (Biobase), el cambio en -197 también permite la unión de SP1 y Lyf-1. SP1 activa el promotor del receptor de glucocorticoide (294), pudiendo unirse físicamente con el receptor de glucocorticoide y mediar en los efectos provocados por este (295). LyF-1, por su parte, estaría implicado en etapas tempranas del desarrollo de linfocitos T y B (296). Además, este algoritmo también predice en este punto, cuanto está presente el alelo C, otro sitio de unión para FREAC2 (FOXF2 o LUN), que también aparece en el cambio -549T>C. Esto provocaría que la variante con los dos cambios de forma simultánea, CCCC, contara con dos sitios de unión para este factor de transcripción. De ser así, puesto que FREAC2 parece provocar activación transcripcional, podría ser esta la explicación para los mayores niveles de actividad promotora y expresión génica que se observan en esta variante respecto al tipo silvestre (CTCT) a las $36 \mathrm{~h}$.

Aunque las discordancias encontradas en los resultados de estos dos algoritmos ponen de manifiesto el carácter teórico de esta aproximación, los dos algoritmos coinciden en predecir la aparición de un sitio de unión a SRF cuando se produce el cambio nucleotídico -197T>C. SRF, es un factor de transcripción implicado en la migración de neutrófilos en respuesta a los procesos inflamatorios $(297,298)$, y relacionado con patologías cardiacas, musculares, digestivas y pulmonares (299).

En definitiva los estudios de unión de factores de transcripción muestran la complejidad de la regulación promotora. Las modificaciones en el patrón de unión del receptor del glucocorticoide determinadas por la presencia de polimorfismos en la región promotora de PTGDR contribuyen a explicar las variaciones en la expresión génica de PTGDR. 
6.5. Análisis de la expresión de citocinas y la respuesta a glucocorticoides

\subsubsection{Influencia de PTGDR y la presencia de polimorfismos en su promotor sobre el} patrón de expresión de citocinas

\section{- Patrón de citocinas a las 12 horas}

El análisis de la expresión de citocinas en los cultivos celulares transfectados con los vectores de expresión, reveló que el aumento de los niveles de PTGDR en el medio, incrementa de forma generalizada la concentración de citocinas, fuere cual fuere la variante presente en el promotor del gen, en comparación con las células control no transfectadas. Estos datos sugieren que la presencia de PTGDR en el medio podría tener un efecto inductor de la respuesta inflamatoria en las células pulmonares A549. Está descrita una inducción preferencial de las citocinas Th2 por parte de la prostaglandina $D$, aunque, como se adelantaba en la introducción, existe controversia sobre si esta acción selectiva hacia una respuesta Th2 se produce a través de su receptor PTGDR o a través de su receptor CRTH2 (300). Entre las citocinas que presentaron mayor concentración en el cultivo celular, con independencia de la presencia o no de PTGDR, la mayoritaria fue IP-10 (CXCL10), que, aunque se ha relacionado principalmente con una respuesta Th1, se ha demostrado que contribuye a la inflamación tipo Th2 en modelos múridos de asma alérgica inducida por OVA, provocando el reclutamiento de linfocitos Th2 y eosinófilos (301). MCP-1 (CCL2), la segunda citocinas más abundante, también actúa en la polarización de células Th0 hacia un fenotipo Th2 (302), y juega un papel importante en la inflamación alérgica de la vía respiratoria (303) y en la hiperplasia de las vías respiratorias en el asma (304). Otras de las citocinas con mayor expresión, como RANTES y VEGF también se asocian 
con la patología asmática aumentando el reclutamiento de células inflamatorias y propulsando la inflamación Th2 en el pulmón $(305,306)$.

Por otra parte, la sobreexpresión de PTGDR en el cultivo celular provoca también aumentos en IL-8. Esta interleucina se ha propuesto como un marcador del control de la enfermedad, junto con el número de neutrófilos (307).

El aumento de todas estas citocinas implicadas en procesos inflamatorios y en la patología asmática cuando se aumentan los niveles de expresión de PTGDR en el cultivo celular, hace pensar que el papel del receptor de prostaglandina $D_{2}$ en el desarrollo de la enfermedad alérgica está relacionado con el patrón de expresión de citocinas. Esta relación estaría en consonancia con los datos obtenidos recientemente por nuestro grupo de trabajo en los que se observan niveles más elevados de expresión de PTGDR en los pacientes alérgicos. Sin embargo, no se detectaron cambios cualitativos en el patrón de citocinas expresado por las células con sobreexpresión de PTGDR respecto a las células control, por lo que no podemos concluir una acción específica del receptor de prostaglandina $D_{2}$ sobre ninguna citocina concreta, sino una acción generalizada en el proceso inflamatorio.

- Influencia de los polimorfismos de PTGDR sobre el patrón de citocinas a las 12 horas

Aunque tras la transfección de las células con los vectores de expresión de PTGDR se produjo un aumento generalizado del nivel de citocinas, no en todos los casos esta respuesta tuvo la misma intensidad. El cultivo celular en el que se produjo una mayor liberación de citocinas fue aquel transfectado con la variante silvestre CTCT $(-613,-549,-441,-197)$ del promotor de PTGDR. Por el contrario, la variante TCCT fue 
la que provocó una liberación de citocinas menor. Comparando estos datos con los datos de expresión de PTGDR, sí se correlaciona una menor liberación de citocinas en la variante TCCT con una menor expresión de PTGDR. Las variantes con mayor expresión, CTCT, CCCC y CCCT, mostraban pequeñas variaciones entre ellas, aunque claramente superaban a la variante TCCT.

\section{- Patrón de citocinas a las 36 horas}

Al ampliar el tiempo experimental hasta las 36 horas, se observó, en primer lugar, que existe un aumento generalizado de las citocinas en comparación con sus valores a las 12 horas, tanto en las células control como en las células con elevada expresión de PTGDR, con la única excepción de MCP-1. Esta citocina mantiene una evolución distinta al resto, disminuyendo su nivel a las 36 horas, de forma similar en las células control que en las transfectadas, por lo que la presencia de PTGDR no parece influir en este hecho. Esta evolución podría ser fruto de una autorregulación de los niveles de citocinas por la interacción entre ellas. De hecho, está descrita una regulación de la citocina MCP-1 en los astrocitomas, donde, tras una primera inducción, le sigue una fase refractaria de represión de MCP-1 mediada por el INF- $\gamma$ (308).

Sin embargo, comparando las células con sobreexpresión de PTGDR y las células control, se observó que mientras que en las variantes CCCC, CCCT y TCCT los niveles de citocinas son superiores a las células control, como ocurría a 12 horas, en el haplotipo silvestre CTCT los niveles de citocinas son menores que en las células control, y por ende, menores que en el resto de haplotipos. Es decir, existe una moderación en el aumento de citocinas en las células que expresan la variante silvestre 
CTCT de PTGDR, con respecto al resto de variantes. Parece que la presencia de la combinación silvestre para los polimorfismos $-613 \mathrm{C}>\mathrm{T},-549 \mathrm{~T}>\mathrm{C},-441 \mathrm{C}>\mathrm{T}$ y $-197 \mathrm{~T}>\mathrm{C}$ en el promotor de PTGDR influye en la evolución temporal de los niveles de citocinas.

Es interesante señalar que el haplotipo silvestre CTCT se ha descrito como significativamente más frecuente en los controles que en los pacientes con asma alérgica $(197,198,203)$. Los datos obtenidos hacen pensar que la combinación de las posiciones silvestres en este haplotipo podría otorgar al promotor del gen PTGDR un control temporal de la expresión de citocinas que diese lugar a una atenuación en etapas posteriores (36 horas). Esta atenuación de la expresión cuando la cantidad de PTGDR en el medio alcanza una concentración elevada, determinaría una reducción de los niveles de citocinas, que a su vez, podría estar ligado con una menor predisposición al proceso alérgico. Por el contrario, los haplotipos con distintas combinaciones de las variantes mutadas, habrían perdido esta capacidad de atenuación de la expresión de citocinas en los pacientes portadores de estas variantes, que podrían estar ligados a una mayor predisposición a desarrollar la enfermedad.

- Influencia de los polimorfismos de PTGDR sobre el patrón de citocinas a las 36 horas

Como consecuencia de lo anterior, al comparar los niveles de citocinas entre las variantes polimórficas de PTGDR, fue la variante silvestre CTCT la que presentó las menores concentraciones. Por el contrario, la variante CCCC es la que mostró los niveles más altos de citocinas de manera global.

Se constata una correlación clara entre los datos observados en la variante CCCC a las 36 horas en todos los ensayos realizados. Este haplotipo presenta los 
valores de actividad promotora más elevados a las 36 horas, que se correlacionan con mayores niveles de expresión y con niveles de citocinas elevados, y que confirman estudios anteriores (197). Esto no se cumple para la variante silvestre CTCT, ya que, aunque presenta los menores niveles de citocinas, no es la combinación que presenta el menor nivel de expresión de PTGDR a las 36 horas. Una explicación a este hecho podría ser que los polimorfismos no solo afecten a la actividad transcripcional del gen, sino también a sus modificaciones postranscripcionales, de tal manera que se provoquen cambios en la actividad del receptor PTGDR.

\subsubsection{Efecto del tratamiento con glucocorticoides sobre la expresión de citocinas en las}

\section{células control}

El tratamiento con dexametasona durante 12 horas provocó un descenso generalizado de las citocinas secretadas por las células control respecto a los valores obtenidos sin tratamiento. Este resultado concuerda con el efecto inmunosupresor y antiinflamatorio de la dexametasona descrito ampliamente en la bibliografía, y confirma una inhibición no selectiva de este corticoide de numerosos mediadores inflamatorios (309-311) reforzando nuestros resultados.

Sin embargo, se observaron aumentos en las citocinas IL-12, VEGF tanto a 12 como a 36 horas, y de IL-7 a 36 horas. Además, se observó un patrón variable en la citocina MIP-1b, que mostraba un descenso leve a 12 horas pero aumentó su concentración a 36 horas.

El aumento en los niveles de IL-12 tras el tratamiento con dexametasona podría explicarse por el papel regulador de esta citocina, capaz de reprimir la respuesta Th2 
mediante la inducción de citoquinas Th1 como el INF- $\gamma$ (312). Recientemente, se ha comprobado, en modelos animales de asma alérgica, que la secreción de IL-12 podría disminuir la liberación de histamina por parte de los mastocitos (313) y, por tanto, disminuir la reacción alérgica. Del mismo modo, el aumento en los niveles de IL-7 tras el tratamiento con dexametasona se podría explicar por su relación con la diferenciación de células Th1 $(314,315)$, como una forma de controlar la respuesta Th2 típica de la enfermedad alérgica.

El factor de crecimiento del endotelio vascular (VEGF) se encuentra tradicionalmente relacionado con el desarrollo de asma alérgica e inflamación Th2 (316), provocando hiperpermeabilidad y edema, respondiendo a la terapia corticoidea con una disminución de sus niveles (317). No se ha encontrado bibliografía que explique estos aumentos de VEGF tras el tratamiento con dexametasona en el modelo celular propuesto. Recientemente se ha descrito que el tratamiento con dexametasona encapsulada en liposomas induce la secreción de citocinas proinflamatorias como TNF$\alpha$ o IL- 6 en macrófagos no estimulados, pero reduce sus niveles bajo condiciones inflamatorias (318). Dado que en nuestros ensayos no se somete a las células a ningún tipo de estimulación inflamatoria, esta podría ser la causa de los patrones de secreción observados.

En el caso de MIP-1b, existen datos contradictorios sobre su papel en los procesos patológicos pulmonares y el asma. Por una parte, MIP-1b es una de las citocinas que se detectan en el lavado broncoalveolar de pacientes con asma (307), y se ha detectado una relación entre niveles más elevados de MIP-1b con la exposición al humo de tabaco y la hiperplasia de glándulas mucosas en el pulmón (319). Sin 
embargo, otros autores aseguran que la expresión intracelular de MIP-1b está disminuida en células CD4+ y CD8+ en asmáticos alérgicos en comparación con no asmáticos, relacionando esta disminución con una polarización de la respuesta Th2 (320), puesto que la síntesis de MIP-1b se asocia con una respuesta inmune de tipo Th1 (321).

\subsubsection{Influencia de los polimorfismos de PTGDR sobre su respuesta a glucocorticoides a}

\section{nivel de expresión de citocinas}

\section{- Efecto a las 12 horas de tratamiento}

Tras 12 horas de tratamiento con dexametasona, se observaron diferentes respuestas en función de la variante haplotípica del promotor de PTGDR presente en las células. Así, la tendencia observada fue que la variante con el haplotipo silvestre CTCT mostrase una disminución más acusada de las citocinas IP-10, RANTES, MIP-1b, IL-6 e IL-8, superando incluso la bajada provocada por la dexametasona en las células control. En las células portadoras de las variantes mutadas, para estas citocinas, el efecto provocado por la dexametasona fue menor, e incluso contrario en algunos casos. Este patrón no se repite en el caso de las citocinas IL-12 y VEGF, en las que las concentraciones más bajas se observaron en las variantes CCCC y TCCT. Si tenemos en cuenta que en las células control el tratamiento corticoideo también provocó un aumento en estas dos citocinas, siguen siendo las variantes mutadas las que menor respuesta muestran.

Parece ser que la presencia de los nucleótidos conservados para los polimorfismos $-613 \mathrm{C}>\mathrm{T},-549 \mathrm{~T}>\mathrm{C},-441 \mathrm{C}>\mathrm{T}$ y $-197 \mathrm{~T}>\mathrm{C}$ en el promotor de $\mathrm{PTGDR}$, como 
ocurre en el haplotipo silvestre CTCT, proporciona una mayor capacidad de respuesta global al tratamiento con dexametasona, no sólo a nivel de la expresión del gen sino también a nivel de la expresión de citocinas. Como ya se ha señalado anteriormente, esta variante se observa con mayor frecuencia en los individuos control $(197,198,203)$ y parece relacionarse también con una mayor sensibilidad a los corticoides.

\section{- Efecto a las $\mathbf{3 6}$ horas de tratamiento}

El análisis de los niveles de citocinas tras 36 horas de tratamiento con dexametasona, manifestó de nuevo, una tendencia de respuesta variable en función del haplotipo de PTGDR presente en las células. La presencia de las variantes mutadas CCCC, CCCT y TCCT provocó aumentos en la concentración de MCP-1 y eotaxina, que en presencia de la variante silvestre CTCT disminuían. Como se ha comentado anteriormente, MCP-1 participa en la inflamación de las vías respiratorias y en la polarización de la respuesta inflamatoria hacia un patrón Th2. La eotaxina, por su parte, es un potente quimioatrayente de eosinófilos que, además, puede provocar una degranulación de los basófilos independiente de la $\lg E(322,323)$, participando así en el mantenimiento de la reacción alérgica y de los síntomas asmáticos. Además, CCCT y TCCT mostraron disminuciones menores de los niveles de IL-6 e IL-8.

De forma global, y con las limitaciones de contar con los datos de citocinas de un único ensayo, parece que la presencia de las variantes haplotípicas CCCT y TCCT, provocan una menor respuesta a la dexametasona, y que la secuencia silvestre CTCT responde mejor. En este sentido, y como se apuntaba anteriormente, la variante CTCT contiene un sitio teórico adicional de unión al receptor de glucocorticoide, que podría provocar esta mayor respuesta al tratamiento. 
Es importante recalcar, por tanto, que las diferencias observadas entre los distintos haplotipos de PTGDR en este trabajo podrían relacionarse con la distinta respuesta al tratamiento observada en la clínica. Por este motivo, sería muy interesante avanzar en esta línea de investigación, y estudiar en futuros trabajos las posibles diferencias genotípicas existentes entre los pacientes que responden bien al tratamiento y aquellos en los que se produce un fracaso terapéutico.

\subsection{Modelo experimental múrido de asma alérgica crónica y respuesta a glucocorticoides}

La provocación de asma alérgica crónica a través de la sensibilización y provocación con ovalbúmina en ratones $\mathrm{BALB} / \mathrm{c}$, es un modelo ampliamente avalado por la bibliografía (324-326). Está comprobado que la exposición crónica a alérgenos en ratones reproduce varios de los puntos clave del asma en humanos como la inflamación mediada por una respuesta Th2 con infiltración eosinofílica de la mucosa respiratoria y la hiperreactividad bronquial (327).

El análisis de los datos obtenidos en nuestro modelo múrido de asma alérgica crónica mostró que la estimulación con OVA en los ratones provoca un aumento generalizado y significativo de la expresión de PTGDR. Este resultado refuerza la posible implicación del recetor de la prostaglandina $D_{2}$ en el desarrollo del asma alérgica. Además, está en concordancia con el papel descrito para PTGDR en el proceso alérgico $(161,187)$ y con resultados previos en nuestro grupo en los que identificamos aumentos de la expresión de PTGDR en sangre periférica de los pacientes alérgicos (San Segundo y col., manuscrito en preparación). 
Al analizar el efecto de la dexametasona sobre este modelo animal se comprobó que PTGDR responde al tratamiento corticoideo. De esta forma se ratifica en un modelo in vivo lo evidenciado en los estudios anteriormente descritos en este trabajo, en los que se observó un control de PTGDR por dexametasona tanto a nivel de actividad promotora, como a nivel de expresión génica y de secreción de citocinas. En este caso se observó una disminución significativa de los niveles de PTGDR tras el tratamiento con el dexametasona, que podría estar relacionada con el papel de los corticoides en el tratamiento de la alergia.

Como se ha descrito anteriormente, en el modelo celular el tratamiento con dexametasona dio lugar a una respuesta tiempo-dependiente que provocó una disminución inicial de la expresión de PTGDR a las 12 horas seguida de un aumento de esta expresión a las 36 horas. En el modelo múrido, el efecto final detectado tras meses de estimulación fue la disminución de los niveles de expresión de PTGDR. En este sentido es importante destacar que mientras que en los ensayos con cultivos celulares se administraba la dexametasona únicamente al inicio del experimento, en el modelo crónico de ratón, las inoculaciones de las dosis del corticoide se repitieron en cada una de las provocaciones, según el patrón temporal establecido. Además, los efectos provocados en el modelo in vivo son el resultado de la interacción entre múltiples redes de citocinas y otros mediadores inflamatorios, junto con la acción provocada por distintos tipos celulares implicados en el proceso alérgico y todos los mecanismos partícipes en la regulación de la respuesta inmunitaria. Por este motivo el efecto final identificado en los ratones puede deberse al modelo crónico desarrollado, en el que la regulación es mucho más compleja, con la intervención de redes de citocinas, posiblemente moduladas, a su vez por otros factores, entre los que puede 
estar el sistema nervioso, no siendo así en el modelo celular. Mientras que en el modelo múrido se analiza el efecto provocado por el tratamiento a largo plazo, en el modelo celular se analiza el efecto provocado a corto plazo, limitado a las 36 horas.

Por otro lado, el hecho de que se observe una respuesta a la dexametasona a nivel de la expresión de PTGDR en un modelo in vivo donde confluyen todos los mecanismos descritos anteriormente, hace que la hipótesis sobre su implicación en el proceso alérgico y en la terapia corticoidea se vea reforzada.

Finalmente, aunque el poder estadístico de los resultados de la estimulación con OVA es muy alto, no ocurre lo mismo con el tratamiento con dexametasona por lo que consideramos que son necesarios estudios con un tamaño de muestra mayor para confirmar estos efectos. 
Efecto de la dexametasona sobre el mecanismo inflamatorio que subyace en el asma 



\section{CONCLUSIONES}

1. La expresión endógena de PTGDR en el cultivo celular A549 es indetectable. Esto hace que el modelo experimental propuesto en base a esta línea celular constituya una aproximación metodológica adecuada para el estudio del efecto de determinados polimorfismos del gen PTGDR sobre su expresión. Del mismo modo, este modelo permite analizar la implicación de PTGDR en la respuesta al tratamiento corticoideo, como lo demuestra la activación de genes de metabolización como CYP3A5.

2. La presencia de polimorfismos en el promotor de PTGDR modifica su actividad en distinta medida según la combinación haplotípica presente. Además, modifica el patrón temporal de expresión, que se mantiene constante en la variante silvestre CTCT.

3. La presencia conjunta de las variantes mutadas de los polimorfismos $-613 C>T$ y -549 T $>C$ parece responsable de una actividad promotora basal y unos niveles de expresión inferiores al resto de combinaciones estudiadas. Por el contrario, la combinación de las variantes mutadas -549T>C y $-197 T>C$ le confiere una actividad promotora basal mayor que el resto lo que sugiere que los efectos de los polimorfismos no deben ser considerados de manera individual en los estudios de asociación.

4. El tratamiento corticoideo induce una activación de la actividad promotora de PTGDR con una intensidad que se modifica según la variante génica presente. De 
nuevo la combinación de variantes mutadas de los polimorfismos $-613 \mathrm{C}>\mathrm{T}$ y $-549 \mathrm{~T}>\mathrm{C}$ provocan una menor capacidad de respuesta a la terapia que la variante silvestre.

5. El efecto del tratamiento con dexametasona sobre la expresión génica de PTGDR muestra una evolución temporal en distintas fases. Las diferencias observadas en los patrones de evolución temporal entre los ensayos de actividad promotora y los ensayos de expresión génica sugieren otros mecanismos reguladores independientes de la región promotora de PTGDR.

6. La presencia de variantes génicas en el promotor de PTGDR modifica la intensidad de la respuesta al tratamiento con corticoide a nivel de su expresión. La variante silvestre es la que mayor grado de repuesta muestra ante la terapia corticoidea aplicada.

7. La presencia de polimorfismos en el promotor de PTGDR provoca modificaciones en el patrón de unión de factores de transcripción que podrían ser responsables de los cambios observados en su actividad promotora y en sus niveles de expresión génica. Además, la pérdida de un sito de reconocimiento del receptor de glucocorticoide en las variantes mutadas podría estar causando una menor respuesta a la terapia corticoidea en comparación con la variante silvestre.

8. La presencia de PTGDR en el medio celular provoca cambios en el patrón de expresión de citocinas en las células pulmonares A549, que varían dependiendo de la variante polimórfica observada. El haplotipo silvestre es capaz de frenar el aumento de la concentración de citocinas provocado, mientras que las variantes portadoras de alelos mutados generan una elevación que se mantiene en el tiempo. Estos datos sugieren, por un lado, que PTGDR estaría implicado en desarrollo de la reacción 
inflamatoria, y, por otro, que la variante silvestre, que en los estudios de asociación se ha observado más frecuentemente en los individuos control, se asociaría con una menor respuesta inflamatoria.

9. El tratamiento con dexametasona provoca una disminución generalizada de los niveles de citocinas, excepto para IL-7, IL-12, VEGF y MIP-1b que podría relacionarse con el control del equilibrio Th1/Th2.

10. La presencia de polimorfismos en la región promotora de PTGDR condiciona la capacidad de respuesta a la acción de corticoides, puesto que se han identificado diferencias en los niveles de citocinas en función del haplotipo presente. Parece existir una tendencia de mayor respuesta al tratamiento con corticoides de la variante silvestre CTCT, y una respuesta más pobre de la variante con el haplotipo TCCT.

11. Se ha comprobado la implicación del receptor de prostaglandina $D_{2}$ (PTGDR) en el desarrollo del asma alérgico in vivo como indica el aumento de sus niveles de expresión tras la exposición a ovalbúmina en el modelo animal llevado a cabo.

12. Se ha observado una disminución de los niveles de expresión de PTGDR en los ratones control tras el tratamiento con dexametasona, así como en los ratones sensibilizados con ovalbúmina y tratados con el corticoide. Sin embargo, el poder estadístico en estos casos fue muy bajo. Esto pone de manifiesto la necesidad de aumentar el tamaño muestral en este modelo, para así confirmar los datos obtenidos.

13. El estudio del efecto de la dexametasona sobre la expresión de PTGDR en dos modelos experimentales ha permitido analizar la distinta respuesta de este gen a corto 
(horas) y largo plazo (meses) lo que proporciona interesante información en relación con la acción temporal del tratamiento corticoideo sobre este gen. 


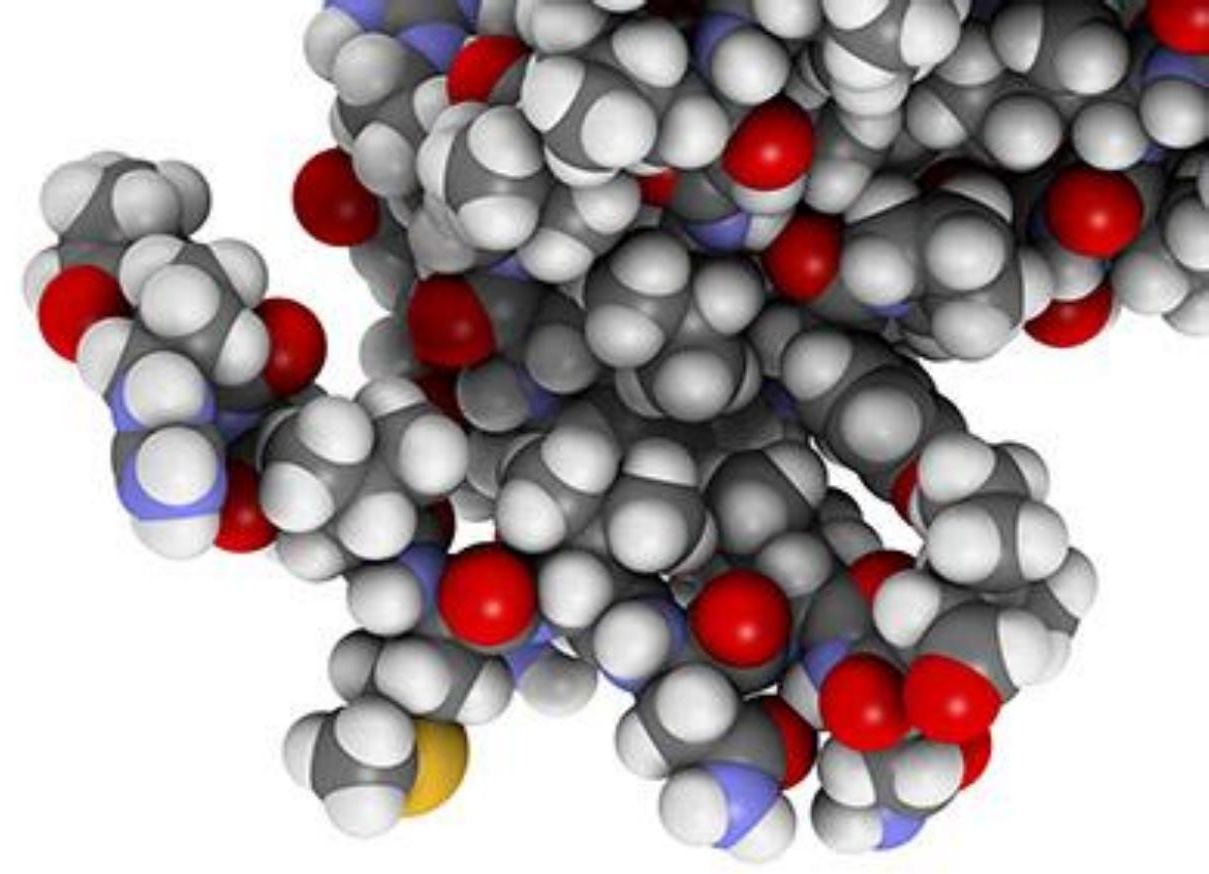

BIBLIOGRAFíA 



\section{Bibliografía}

1. dicciomed.eusal.es esteroide [Internet]. [cited 2016 Mar 27]. Available from: http://dicciomed.eusal.es/palabra/esteroide

2. Libro de las enfermedades alérgicas de la Fundación BBVA. Fundacion BBVA; 2012. 488 p.

3. Grossman AB, Jameson JL, Groot LJD. Endocrinology Adult and Pediatric: The Adrenal Gland. Elsevier Health Sciences; 2013. 867 p.

4. Wilks SS, Daldy TM. A Collection of the Published Writings of the Late Thomas Addison, M.D.: Physician to Guy's Hospital. New Sydenham Society; 1868. 324 p.

5. Francisco Pizarro. Historia de los corticoides. Rev Médica Clínica Las Condes. 2014;25(4):858-60.

6. Gamarra AI. Historia del Lupus: Y del Síndrome Antifosfolipídico. Antonio Iglesias Gamarra; 2003. 744 p.

7. Young FG. Thomas Addison and the Background to Cortisone. Br Med J. 1951 Dec 29;2(4747):1535-41.

8. Cimaz R. Systemic Corticosteroids for Inflammatory Disorders in Pediatrics. Springer; 2015. $186 \mathrm{p}$.

9. $\quad \mathrm{Tg}$ B. History of the development of corticosteroid therapy. Clin Exp Rheumatol. 2010 Dec;29(5 Suppl 68):S - 5-12.

10. Gómez Ordóñez S, Álvarez G, María Á, Plata V, L E. Corticoids: 60 Years Later a Pending Subject. Rev Cienc Salud. 2007 Dec;5(3):58-69.

11. Martínez Cordero H, Montenegro González P, Restrepo JF, Rondón Herrera F, Quintana G, Iglesias Gamarra A. Historia de los glucocorticoides. Rev Colomb Reum. 2010 Jul;17(3):147-71.

12. Fernández RP. Reacciones adversas medicamentosas: valoración clínica. Ediciones Díaz de Santos; 1992. 698 p.

13. Medicamentos: Un Viaje a Lo Largo de la Evolucion Del Descubrimiento de Farmacos. Univ Santiago de Compostela; 2008. 512 p.

14. Héctor A. Serra, Juan Manuel Roganovich, Leonardo F. L. Rizzo. Glucocorticoides: paradigma de la medicina traslacional. De lo molecular al uso clínico. Sci Electron Libr Online. 2012;72:158-70.

15. Słapa RZ, Jakubowski WS, Dobruch-Sobczak K, Kasperlik-Załuska AA. Standards of ultrasound imaging of the adrenal glands. J Ultrason. 2015 Dec;15(63):377-87. 
16. Anatomy Of Adrenal Gland, Cross Section Canvas Print / Canvas Art by Stocktrek Images [Internet]. Fine Art America. [cited 2016 Mar 2]. Available from: http://fineartamerica.com/products/anatomy-of-adrenal-gland-crosssection-stocktrek-images-canvas-print.html

17. Vrezas I, Willenberg HS, Bornstein SR. Adrenal Cortex, Development, Anatomy, Physiology. In: De Groot LJ, Beck-Peccoz P, Chrousos G, Dungan K, Grossman A, Hershman JM, et al., editors. Endotext [Internet]. South Dartmouth (MA): MDText.com, Inc.; 2000 [cited 2016 Mar 2]. Available from: http://www.ncbi.nlm.nih.gov/books/NBK278945/

18. Gądek-Michalska A, Tadeusz J, Rachwalska P, Bugajski J. Cytokines, prostaglandins and nitric oxide in the regulation of stress-response systems. Pharmacol Rep PR. 2013;65(6):1655-62.

19. Smith SM, Vale WW. The role of the hypothalamic-pituitary-adrenal axis in neuroendocrine responses to stress. Dialogues Clin Neurosci. 2006 Dec;8(4):38395 .

20. Walker JJ, Spiga F, Gupta R, Zhao Z, Lightman SL, Terry JR. Rapid intraadrenal feedback regulation of glucocorticoid synthesis. J R Soc Interface [Internet]. 2015 Jan 6 [cited 2016 Mar 3];12(102). Available from: http://www.ncbi.nlm.nih.gov/pmc/articles/PMC4277077/

21. Hyman SE. How adversity gets under the skin. Nat Neurosci. 2009 Mar;12(3):241-3.

22. Arderiu XF. Bioquímica clínica y patología molecular. II. Reverte; 1998. 556 p.

23. Wagner CA. Effect of Mineralocorticoids on Acid-Base Balance. Nephron Physiol. 2014;128(1-2):26-34.

24. Fernández PL. Velázquez. Farmacología Básica y Clínica. Ed. Médica Panamericana; $1404 \mathrm{p}$.

25. Bioquímica clínica: de la patología al laboratorio. Ergon; 2008. 605 p.

26. Castrillo JMA, Álvarez EV. Endocrinologia Medica Y Metabolismo. Universidad de Oviedo; 2007. 428 p.

27. Yúfera EP. Química orgánica básica y aplicada: de la molécula a la industria. Reverte; 1995. 490 p.

28. Chrousos G, Pavlaki AN, Magiakou MA. Glucocorticoid Therapy and Adrenal Suppression. In: De Groot LJ, Beck-Peccoz P, Chrousos G, Dungan K, Grossman A, Hershman JM, et al., editors. Endotext [Internet]. South Dartmouth (MA): MDText.com, Inc.; 2000 [cited 2016 Mar 3]. Available from: http://www.ncbi.nlm.nih.gov/books/NBK279156/

29. Hill RW, Wyse GA. Fisiología animal. Akal; 1992. 655 p. 
30. Ramamoorthy S, Cidlowski JA. Exploring the molecular mechanisms of glucocorticoid receptor action from sensitivity to resistance. Endocr Dev. 2013;24:41-56.

31. Lu NZ, Cidlowski JA. Translational regulatory mechanisms generate N-terminal glucocorticoid receptor isoforms with unique transcriptional target genes. Mol Cell. 2005 Apr 29;18(3):331-42.

32. Oakley RH, Sar M, Cidlowski JA. The human glucocorticoid receptor beta isoform. Expression, biochemical properties, and putative function. J Biol Chem. 1996 Apr 19;271(16):9550-9.

33. Necela BM, Cidlowski JA. Mechanisms of glucocorticoid receptor action in noninflammatory and inflammatory cells. Proc Am Thorac Soc. 2004;1(3):239_ 46.

34. Nicolaides NC, Galata Z, Kino T, Chrousos GP, Charmandari E. The human glucocorticoid receptor: molecular basis of biologic function. Steroids. 2010 Jan;75(1):1-12.

35. Smoak KA, Cidlowski JA. Mechanisms of glucocorticoid receptor signaling during inflammation. Mech Ageing Dev. 2004 Nov;125(10-11):697-706.

36. Pratt WB, Toft DO. Steroid receptor interactions with heat shock protein and immunophilin chaperones. Endocr Rev. 1997 Jun;18(3):306-60.

37. Galigniana NM, Ballmer LT, Toneatto J, Erlejman AG, Lagadari M, Galigniana MD. Regulation of the glucocorticoid response to stress-related disorders by the Hsp90-binding immunophilin FKBP51. J Neurochem. 2012 Jul 1;122(1):4-18.

38. Jochems J, Teegarden SL, Chen Y, Boulden J, Challis C, Ben-Dor GA, et al. Enhancement of stress resilience through Hdac6-mediated regulation of glucocorticoid receptor chaperone dynamics. Biol Psychiatry. 2015 Feb 15;77(4):345-55.

39. Pratt WB, Morishima Y, Osawa Y. The Hsp90 Chaperone Machinery Regulates Signaling by Modulating Ligand Binding Clefts. J Biol Chem. 2008 Aug 22;283(34):22885-9.

40. Evolution of the glucocorticoid receptor | Cavalcade of Mammals [Internet]. [cited 2016 Feb 29]. Available from: http://jimlund.org/blog/?p=168

41. Echeverría PC, Mazaira G, Erlejman A, Gomez-Sanchez C, Pilipuk GP, Galigniana MD. Nuclear Import of the Glucocorticoid Receptor-hsp90 Complex through the Nuclear Pore Complex Is Mediated by Its Interaction with Nup62 and Importin $\beta$. Mol Cell Biol. 2009 Sep;29(17):4788-97.

42. Carrigan A, Walther RF, Salem HA, Wu D, Atlas E, Lefebvre YA, et al. An active nuclear retention signal in the glucocorticoid receptor functions as a strong inducer of transcriptional activation. J Biol Chem. 2007 Apr 13;282(15):1096371. 
43. Beck IME, Vanden Berghe W, Vermeulen L, Yamamoto KR, Haegeman G, De Bosscher K. Crosstalk in inflammation: the interplay of glucocorticoid receptorbased mechanisms and kinases and phosphatases. Endocr Rev. 2009 Dec;30(7):830-82.

44. Buttgereit F, Straub RH, Wehling M, Burmester G-R. Glucocorticoids in the treatment of rheumatic diseases: an update on the mechanisms of action. Arthritis Rheum. 2004 Nov;50(11):3408-17.

45. Clark AR, Belvisi MG. Maps and legends: the quest for dissociated ligands of the glucocorticoid receptor. Pharmacol Ther. 2012 Apr;134(1):54-67.

46. Meijsing SH, Pufall MA, So AY, Bates DL, Chen L, Yamamoto KR. DNA binding site sequence directs glucocorticoid receptor structure and activity. Science. 2009 Apr 17;324(5925):407-10.

47. Kumar R, Thompson EB. Folding of the glucocorticoid receptor N-terminal transactivation function: dynamics and regulation. Mol Cell Endocrinol. 2012 Jan 30;348(2):450-6.

48. Bain DL, Yang Q, Connaghan KD, Robblee JP, Miura MT, Degala GD, et al. Glucocorticoid receptor-DNA interactions: binding energetics are the primary determinant of sequence-specific transcriptional activity. J Mol Biol. 2012 Sep $7 ; 422(1): 18-32$.

49. Almawi WY, Melemedjian OK. Negative regulation of nuclear factor-kappaB activation and function by glucocorticoids. J Mol Endocrinol. 2002 Apr;28(2):69-78.

50. Maneechotesuwan K, Yao X, Ito K, Jazrawi E, Usmani OS, Adcock IM, et al. Suppression of GATA-3 nuclear import and phosphorylation: a novel mechanism of corticosteroid action in allergic disease. PLoS Med. 2009 May 12;6(5):e1000076.

51. Peti W, Page R. Molecular basis of MAP kinase regulation. Protein Sci Publ Protein Soc. 2013 Dec;22(12):1698-710.

52. Karin M. The Regulation of AP-1 Activity by Mitogen-activated Protein Kinases. J Biol Chem. 1995 Jul 14;270(28):16483-6.

53. Yang Y, Kim SC, Yu T, Yi Y-S, Rhee MH, Sung G-H, et al. Functional Roles of p38 Mitogen-Activated Protein Kinase in Macrophage-Mediated Inflammatory Responses. Mediators Inflamm [Internet]. 2014 [cited 2016 Mar 3];2014. Available from: http://www.ncbi.nlm.nih.gov/pmc/articles/PMC3977509/

54. Yang YH, Toh M-L, Clyne CD, Leech M, Aeberli D, Xue J, et al. Annexin 1 Negatively Regulates IL-6 Expression via Effects on p38 MAPK and MAPK Phosphatase-1. J Immunol. 2006 Dec 1;177(11):8148-53.

55. Ayroldi E, Zollo O, Macchiarulo A, Di Marco B, Marchetti C, Riccardi C. Glucocorticoid-induced leucine zipper inhibits the Raf-extracellular signal- 
regulated kinase pathway by binding to Raf-1. Mol Cell Biol. 2002 Nov;22(22):7929-41.

56. Ayroldi E, Cannarile L, Migliorati G, Nocentini G, Delfino DV, Riccardi C. Mechanisms of the anti-inflammatory effects of glucocorticoids: genomic and nongenomic interference with MAPK signaling pathways. FASEB J. 2012 Dec 1;26(12):4805-20.

57. Chen Y, Watson AM, Williamson CD, Rahimi M, Liang C, Colberg-Poley AM, et al. Glucocorticoid receptor and histone deacetylase-2 mediate dexamethasoneinduced repression of MUC5AC gene expression. Am J Respir Cell Mol Biol. 2012 Nov;47(5):637-44.

58. Ronchetti S, Migliorati G, Riccardi C. GILZ as a Mediator of the AntiInflammatory Effects of Glucocorticoids. Front Endocrinol. 2015;6:170.

59. Burnsides C, Corry J, Alexander J, Balint C, Cosmar D, Phillips G, et al. Ex vivo stimulation of whole blood as a means to determine glucocorticoid sensitivity. J Inflamm Res. 2012;5:89-97.

60. Ni Z, Tang J, Cai Z, Yang W, Zhang L, Chen Q, et al. A new pathway of glucocorticoid action for asthma treatment through the regulation of PTEN expression. Respir Res. 2011;12:47.

61. Ben Y, Chen J, Zhu R, Gao L, Bai C. Upregulation of AQP3 and AQP5 induced by dexamethasone and ambroxol in A549 cells. Respir Physiol Neurobiol. 2008 Apr 30;161(2):111-8.

62. Barnes PJ. Glucocorticosteroids: current and future directions. Br J Pharmacol. 2011 May;163(1):29-43.

63. Barnes PJ. Corticosteroids: the drugs to beat. Eur J Pharmacol. 2006 Mar 8;533(1-3):2-14.

64. Smoak K, Cidlowski JA. Glucocorticoids regulate tristetraprolin synthesis and posttranscriptionally regulate tumor necrosis factor alpha inflammatory signaling. Mol Cell Biol. 2006 Dec;26(23):9126-35.

65. John S, Sabo PJ, Thurman RE, Sung M-H, Biddie SC, Johnson TA, et al. Chromatin accessibility pre-determines glucocorticoid receptor binding patterns. Nat Genet. 2011 Mar;43(3):264-8.

66. Biddie SC, Conway-Campbell BL, Lightman SL. Dynamic regulation of glucocorticoid signalling in health and disease. Rheumatol Oxf Engl. 2012 Mar;51(3):403-12.

67. Gruver-Yates AL, Cidlowski JA. Tissue-Specific Actions of Glucocorticoids on Apoptosis: A Double-Edged Sword. Cells. 2013 Mar 26;2(2):202-23. 
68. Schlossmacher G, Stevens A, White A. Glucocorticoid receptor-mediated apoptosis: mechanisms of resistance in cancer cells. J Endocrinol. 2011 Oct;211(1):17-25.

69. Lynch JT, Rajendran R, Xenaki G, Berrou I, Demonacos C, Krstic-Demonacos $\mathrm{M}$. The role of glucocorticoid receptor phosphorylation in Mcl-1 and NOXA gene expression. Mol Cancer. 2010;9:38.

70. Matsumura Y. Heterogeneity of glucocorticoid resistance in patients with bronchial asthma. Int J Biomed Sci IJBS. 2010 Sep;6(3):158-66.

71. Alangari AA. Genomic and non-genomic actions of glucocorticoids in asthma. Ann Thorac Med. 2010 Jul;5(3):133-9.

72. Vernocchi S, Battello N, Schmitz S, Revets D, Billing AM, Turner JD, et al. Membrane glucocorticoid receptor activation induces proteomic changes aligning with classical glucocorticoid effects. Mol Cell Proteomics MCP. 2013 Jul;12(7):1764-79.

73. Dávila I, Jáuregui I, Olaguibel JM, Zubeldia JM. Tratado de Alergología. In Ergon; 2015.

74. Masoli M, Fabian D, Holt S, Beasley R, Global Initiative for Asthma (GINA) Program. The global burden of asthma: executive summary of the GINA Dissemination Committee Report. Allergy. 2004 May 1;59(5):469-78.

75. GEMA 4.0: Guía española para el manejo del asma. [Internet]. Comité Ejecutivo de la GEMA; 2015. Available from: www.gemasma.com

76. Zhang J, Paré PD, Sandford AJ. Recent advances in asthma genetics. Respir Res. 2008;9(1):4.

77. Middleton E. Middleton's Allergy: Principles \& Practice. Mosby Elsevier; 2009. $10 \mathrm{p}$.

78. Barnes PJ, Chung KF, Page CP. Inflammatory Mediators of Asthma: An Update. Pharmacol Rev. 1998 Dec 1;50(4):515-96.

79. Bradding P, Walls AF, Holgate ST. The role of the mast cell in the pathophysiology of asthma. J Allergy Clin Immunol. 2006 Jun;117(6):1277-84.

80. Possa SS, Leick EA, Prado CM, Martins MA, Tibério IFLC. Eosinophilic Inflammation in Allergic Asthma. Front Pharmacol [Internet]. 2013 Apr 17 [cited 2016 May 8];4. Available from: http://www.ncbi.nlm.nih.gov/pmc/articles/PMC3627984/

81. Travers J, Rothenberg ME. Eosinophils in mucosal immune responses. Mucosal Immunol. 2015 May;8(3):464-75.

82. Robinson DS. The role of the T cell in asthma. J Allergy Clin Immunol. 2010 Dec 1;126(6):1081-91. 
83. Hammad H, Lambrecht BN. Dendritic cells and epithelial cells: linking innate and adaptive immunity in asthma. Nat Rev Immunol. 2008 Mar;8(3):193-204.

84. Olga Ciepiela MO. Neutrophils in asthma-A review. Respir Physiol Amp Neurobiol. 2014;209.

85. Gandhi VD, Vliagoftis H. Airway epithelium interactions with aeroallergens: role of secreted cytokines and chemokines in innate immunity. Front Immunol. 2015;6:147.

86. Bang B-R, Chun E, Shim E-J, Lee H-S, Lee S-Y, Cho S-H, et al. Alveolar macrophages modulate allergic inflammation in a murine model of asthma. Exp Mol Med. 2011 May 31;43(5):275-80.

87. Ménard G, Bissonnette EY. Priming of Alveolar Macrophages by Leukotriene D4. Am J Respir Cell Mol Biol. 2000 Oct 1;23(4):572-7.

88. Zhang J-M, An J. Cytokines, Inflammation and Pain. Int Anesthesiol Clin. 2007;45(2):27-37.

89. Padrón-Morales J, García-Solaesa V, Isidoro-García M, Hernández-Hernández L, García-Sánchez A, Hincapié-López G, et al. Implications of cytokine genes in allergic asthma. Allergol Immunopathol (Madr). 2014 Dec;42(6):603-8.

90. Padrón-Morales J, Sanz C, Dávila I, Muñoz-Bellido F, Lorente F, Isidoro-García M. Polymorphisms of the IL12B, IL1B, and TNFA genes and susceptibility to asthma. J Investig Allergol Clin Immunol. 2013;23(7):487-94.

91. Mahajan S, Mehta A. Role of cytokines in pathophysiology of asthma. Iran J Pharmacol Ther. 2006;5:1-14.

92. Zimmermann N, Hershey GK, Foster PS, Rothenberg ME. Chemokines in asthma: cooperative interaction between chemokines and IL-13. J Allergy Clin Immunol. 2003 Feb;111(2):227-42; quiz 243.

93. Wenzel SE. The role of leukotrienes in asthma. Prostaglandins Leukot Essent Fatty Acids. 2003 Sep;69(2-3):145-55.

94. White MV. The role of histamine in allergic diseases. J Allergy Clin Immunol. 1990 Oct;86(4 Pt 2):599-605.

95. Prado CM, Martins MA, Tibério IFLC, Prado CM, Martins MA, Tibério IFLC. Nitric Oxide in Asthma Physiopathology, Nitric Oxide in Asthma Physiopathology. Int Sch Res Not Int Sch Res Not. 2011 Apr 19;2011, 2011:e832560.

96. Bazsó A, Szodoray P, Szappanos Á, Korda J, Pálfi P, Kiss E, et al. Systemic Autoimmune, Rheumatic Diseases and Coinciding Psoriasis: Data from a Large Single-Centre Registry and Review of the Literature. Mediators Inflamm. 2015;2015:657907. 
97. Zhang Y-P, Gong Y, Zeng QY, Hou Z-D, Xiao Z-Y. A long-term, observational cohort study on the safety of low-dose glucocorticoids in ankylosing spondylitis: adverse events and effects on bone mineral density, blood lipid and glucose levels and body mass index. BMJ Open. 2015;5(6):e006957.

98. Kang HS, Chung HS, Kang K-S, Han KH. High-dose methylprednisolone pulse therapy for treatment of refractory intestinal involvement caused by HenochSchönlein purpura: a case report. J Med Case Reports. 2015;9:65.

99. Thomas AL, Coarfa C, Qian J, Wilkerson JJ, Rajapakshe K, Krett NL, et al. Identification of potential glucocorticoid receptor therapeutic targets in multiple myeloma. Nucl Recept Signal. 2015;13:e006.

100. Rodríguez-Orozco AR, P JF, A JV. Esteroides inhalados en asma. Aspectos farmacológicos que fundamentan su elección [Internet]. Revista Mexicana de Ciencias Farmacéuticas. 2010 [cited 2016 Feb 18]. Available from: http://www.redalyc.org/articulo.oa?id=57916078002

101. Badorrek P, Hohlfeld JM, Krug N, Joshi A, Raut A. Efficacy and safety of a novel nasal steroid, S0597, in patients with seasonal allergic rhinitis. Ann Allergy Asthma Immunol Off Publ Am Coll Allergy Asthma Immunol. 2015 Oct;115(4):325-9.e1.

102. Berger WE, Jacobs RL, Amar NJ, Tantry SK, Li J, Small CJ. Efficacy and safety of beclomethasone dipropionate nasal aerosol in children with perennial allergic rhinitis. Ann Allergy Asthma Immunol Off Publ Am Coll Allergy Asthma Immunol. 2015 Aug;115(2):130-6.

103. Baiula M, Bedini A, Baldi J, Cavet ME, Govoni P, Spampinato S. Mapracorat, a selective glucocorticoid receptor agonist, causes apoptosis of eosinophils infiltrating the conjunctiva in late-phase experimental ocular allergy. Drug Des Devel Ther. 2014;8:745-57.

104. van Aalderen WMC, Sprikkelman AB. Inhaled corticosteroids in childhood asthma: the story continues. Eur J Pediatr. 2011 Jun;170(6):709-18.

105. Lima JJ, Blake KV, Tantisira KG, Weiss ST. Pharmacogenetics of asthma. Curr Opin Pulm Med. 2009 Jan;15(1):57-62.

106. Amparo Escribano Montaner, Marcel Ibero Iborra, Jesús Garde Garde, Silvia Gartner, José Ramón Villa Asensi, Javier Pérez Frías. Protocolos terapéuticos en el asma infantil. In: Protocolos Diagnósticos y terapéuticos en Pediatría. Asociación Española de Pediatría (AEP). 2003. p. 187-210.

107. Kim M-Y, Song W-J, Cho S-H. Pharmacotherapy in the management of asthma in the elderly: a review of clinical studies. Asia Pac Allergy. 2016 Jan;6(1):3-15.

108. Singas E, Karpel JP. Profile of ciclesonide for the maintenance treatment of asthma. Ther Clin Risk Manag. 2011;7:351-8. 
109. P. PB, F. FH, S. SW. ASMA SEVERA EN ADULTOS: ENFOQUE DIAGNÓSTICO Y TRATAMIENTO. Rev Médica Clínica Las Condes. 2015 May;26(3):267-75.

110. Collins AD, Beigelman A. An update on the efficacy of oral corticosteroids in the treatment of wheezing episodes in preschool children. Ther Adv Respir Dis. 2014 Dec;8(6):182-90.

111. Chung KF, Wenzel SE, Brozek JL, Bush A, Castro M, Sterk PJ, et al. International ERS/ATS guidelines on definition, evaluation and treatment of severe asthma. Eur Respir J. 2014 Feb;43(2):343-73.

112. Fuhlbrigge A, Peden D, Apter AJ, Boushey HA, Camargo CA, Gern J, et al. Asthma outcomes: exacerbations. J Allergy Clin Immunol. 2012 Mar;129(3 Suppl):S34-48.

113. Lefebvre P, Duh MS, Lafeuille M-H, Gozalo L, Desai U, Robitaille M-N, et al. Acute and chronic systemic corticosteroid-related complications in patients with severe asthma. J Allergy Clin Immunol. 2015 Dec;136(6):1488-95.

114. Keeney GE, Gray MP, Morrison AK, Levas MN, Kessler EA, Hill GD, et al. Dexamethasone for Acute Asthma Exacerbations in Children: A Meta-analysis. Pediatrics. 2014 Mar;133(3):493-9.

115. Cross KP, Paul RI, Goldman RD. Single-dose dexamethasone for mild-tomoderate asthma exacerbations. Can Fam Physician. 2011 Oct;57(10):1134-6.

116. Luhadia SK. Steroid resistant asthma. J Assoc Physicians India. 2014 Mar;62(3 Suppl):38-40.

117. Hakonarson H, Bjornsdottir US, Halapi E, Bradfield J, Zink F, Mouy M, et al. Profiling of genes expressed in peripheral blood mononuclear cells predicts glucocorticoid sensitivity in asthma patients. Proc Natl Acad Sci U S A. 2005 Oct 11;102(41):14789-94.

118. Ungvári I, Hullám G, Antal P, Kiszel PS, Gézsi A, Hadadi É, et al. Evaluation of a Partial Genome Screening of Two Asthma Susceptibility Regions Using Bayesian Network Based Bayesian Multilevel Analysis of Relevance. PLoS ONE [Internet]. 2012 Mar 14 [cited 2016 Feb 15];7(3). Available from: http://www.ncbi.nlm.nih.gov/pmc/articles/PMC3303848/

119. Donn R, Berry A, Stevens A, Farrow S, Betts J, Stevens R, et al. Use of gene expression profiling to identify a novel glucocorticoid sensitivity determining gene, BMPRII. FASEB J Off Publ Fed Am Soc Exp Biol. 2007 Feb;21(2):40214.

120. Tantisira KG, Lasky-Su J, Harada M, Murphy A, Litonjua AA, Himes BE, et al. Genomewide association between GLCCI1 and response to glucocorticoid therapy in asthma. N Engl J Med. 2011 Sep 29;365(13):1173-83. 
121. Wenzel SE, Schwartz LB, Langmack EL, Halliday JL, Trudeau JB, Gibbs RL, et al. Evidence that severe asthma can be divided pathologically into two inflammatory subtypes with distinct physiologic and clinical characteristics. Am J Respir Crit Care Med. 1999 Sep;160(3):1001-8.

122. Douwes J, Gibson P, Pekkanen J, Pearce N. Non-eosinophilic asthma: importance and possible mechanisms. Thorax. 2002 Jul;57(7):643-8.

123. Ilmarinen $\mathrm{P}$, Kankaanranta $\mathrm{H}$. Eosinophil apoptosis as a therapeutic target in allergic asthma. Basic Clin Pharmacol Toxicol. 2014 Jan;114(1):109-17.

124. Kim Y-M, Kim Y-S, Jeon SG, Kim Y-K. Immunopathogenesis of allergic asthma: more than the th2 hypothesis. Allergy Asthma Immunol Res. 2013 Jul;5(4):189-96.

125. Kudo M, Ishigatsubo Y, Aoki I. Pathology of asthma. Front Microbiol. 2013;4:263.

126. Chang Y, Al-Alwan L, Risse P-A, Halayko AJ, Martin JG, Baglole CJ, et al. Th17-associated cytokines promote human airway smooth muscle cell proliferation. FASEB J Off Publ Fed Am Soc Exp Biol. 2012 Dec;26(12):515260 .

127. Vazquez-Tello A, Halwani R, Hamid Q, Al-Muhsen S. Glucocorticoid receptorbeta up-regulation and steroid resistance induction by IL-17 and IL-23 cytokine stimulation in peripheral mononuclear cells. J Clin Immunol. 2013 Feb;33(2):466-78.

128. Ather JL, Fortner KA, Budd RC, Anathy V, Poynter ME. Serum amyloid A inhibits dendritic cell apoptosis to induce glucocorticoid resistance in CD4(+) T cells. Cell Death Dis. 2013;4:e786.

129. Balzar S, Fajt ML, Comhair SAA, Erzurum SC, Bleecker E, Busse WW, et al. Mast Cell Phenotype, Location, and Activation in Severe Asthma. Am J Respir Crit Care Med. 2011 Feb 1;183(3):299-309.

130. Kobayashi Y, Mercado N, Barnes PJ, Ito K. Defects of protein phosphatase 2A causes corticosteroid insensitivity in severe asthma. PloS One. 2011;6(12):e27627.

131. Sher ER, Leung DY, Surs W, Kam JC, Zieg G, Kamada AK, et al. Steroidresistant asthma. Cellular mechanisms contributing to inadequate response to glucocorticoid therapy. J Clin Invest. 1994 Jan;93(1):33-9.

132. Corrigan CJ, Loke T-K. Clinical and molecular aspects of glucocorticoid resistant asthma. Ther Clin Risk Manag. 2007 Oct;3(5):771-87.

133. Dysregulation of interleukin 4, interleukin 5, and interferon gamma gene expression in steroid-resistant asthma. J Exp Med. 1995 Jan 1;181(1):33-40. 
134. Hew M, Bhavsar P, Torrego A, Meah S, Khorasani N, Barnes PJ, et al. Relative corticosteroid insensitivity of peripheral blood mononuclear cells in severe asthma. Am J Respir Crit Care Med. 2006 Jul 15;174(2):134-41.

135. Gagliardo R, Chanez P, Mathieu M, Bruno A, Costanzo G, Gougat C, et al. Persistent activation of nuclear factor-kappaB signaling pathway in severe uncontrolled asthma. Am J Respir Crit Care Med. 2003 Nov 15;168(10):1190-8.

136. Ito K, Getting SJ, Charron CE. Mode of glucocorticoid actions in airway disease. ScientificWorldJournal. 2006;6:1750-69.

137. Allen JC, Seidel P, Schlosser T, Ramsay EE, Ge Q, Ammit AJ. Cyclin D1 in ASM Cells from Asthmatics Is Insensitive to Corticosteroid Inhibition. J Allergy. 2012;2012:307838.

138. Papi A, Contoli M, Adcock IM, Bellettato C, Padovani A, Casolari P, et al. Rhinovirus infection causes steroid resistance in airway epithelium through nuclear factor $\kappa \mathrm{B}$ and c-Jun $\mathrm{N}$-terminal kinase activation. J Allergy Clin Immunol. 2013 Nov;132(5):1075-85.e6.

139. da Silva EZM, Jamur MC, Oliver C. Mast Cell Function. J Histochem Cytochem. 2014 Oct;62(10):698-738.

140. Roitt. Inmunologia. Fundamentos. Ed. Médica Panamericana; 2008. 548 p.

141. Hart PH. Regulation of the inflammatory response in asthma by mast cell products. Immunol Cell Biol. 2001 Apr;79(2):149-53.

142. Krystel-Whittemore M, Dileepan KN, Wood JG. Mast Cell: A Multi-Functional Master Cell. Front Immunol [Internet]. 2016 Jan 6 [cited 2016 Feb 27];6. Available from: http://www.ncbi.nlm.nih.gov/pmc/articles/PMC4701915/

143. Bischoff SC. Role of mast cells in allergic and non-allergic immune responses: comparison of human and murine data. Nat Rev Immunol. 2007 Feb;7(2):93104.

144. Fanning LB, Boyce JA. Basic Science for the Clinician: Lipid Mediators. Ann Allergy Asthma Immunol Off Publ Am Coll Allergy Asthma Immunol. 2013 Sep;111(3):155-62.

145. Lasa M, Mahtani KR, Finch A, Brewer G, Saklatvala J, Clark AR. Regulation of cyclooxygenase 2 mRNA stability by the mitogen-activated protein kinase p38 signaling cascade. Mol Cell Biol. 2000 Jun;20(12):4265-74.

146. Tilley SL, Coffman TM, Koller BH. Mixed messages: modulation of inflammation and immune responses by prostaglandins and thromboxanes. J Clin Invest. $2001 \mathrm{Jul} 1 ; 108(1): 15-23$.

147. Moghaddami M, Ranieri E, James M, Fletcher J, Cleland LG. Prostaglandin D(2) in inflammatory arthritis and its relation with synovial fluid dendritic cells. Mediators Inflamm. 2013;2013:329494. 
148. Wu D, Zheng S, Li W, Yang L, Liu Y, Zheng X, et al. Novel biphasic role of resolvin D1 on expression of cyclooxygenase-2 in lipopolysaccharide-stimulated lung fibroblasts is partly through PI3K/AKT and ERK2 pathways. Mediators Inflamm. 2013;2013:964012.

149. Terao A, Huang Z-L, Wisor JP, Mochizuki T, Gerashchenko D, Urade Y, et al. Gene Expression in the Rat Brain During Prostaglandin D2- and Adenosinergically-Induced Sleep. J Neurochem. 2008 May;105(4):1480-98.

150. Evans JF, Islam S, Urade Y, Eguchi N, Ragolia L. The lipocalin-type prostaglandin D2 synthase knockout mouse model of insulin resistance and obesity demonstrates early hypothalamic-pituitary-adrenal axis hyperactivity. $\mathrm{J}$ Endocrinol. 2013 Feb;216(2):169-80.

151. Lehninger AL, Cox MM. Principios de bioquímica. Omega; 2006. 1232 p.

152. Wang P, Guan P-P, Guo C, Zhu F, Konstantopoulos K, Wang Z-Y. Fluid shear stress-induced osteoarthritis: roles of cyclooxygenase- 2 and its metabolic products in inducing the expression of proinflammatory cytokines and matrix metalloproteinases. FASEB J. 2013 Dec;27(12):4664-77.

153. Kugathas S, Audouze K, Ermler S, Orton F, Rosivatz E, Scholze M, et al. Effects of Common Pesticides on Prostaglandin D2 (PGD2) Inhibition in SC5 Mouse Sertoli Cells, Evidence of Binding at the COX2 Active Site, and Implications for Endocrine Disruption. Environ Health Perspect. 2015 Sep 11;

154. Rossitto M, Ujjan S, Poulat F, Boizet-Bonhoure B. Multiple roles of the prostaglandin D2 signaling pathway in reproduction. Reprod Camb Engl. 2015 Jan;149(1):R49-58.

155. Joo M, Sadikot RT. PGD Synthase and PGD2 in Immune Resposne. Mediators Inflamm [Internet]. 2012 [cited 2016 Feb 25];2012. Available from: http://www.ncbi.nlm.nih.gov/pmc/articles/PMC3389719/

156. Nagai H. Prostaglandin as a target molecule for pharmacotherapy of allergic inflammatory diseases. Allergol Int Off J Jpn Soc Allergol. 2008 Sep;57(3):18796.

157. Sykes L, MacIntyre DA, Teoh TG, Bennett PR. Anti-inflammatory prostaglandins for the prevention of preterm labour. Reproduction. 2014 Aug 1;148(2):R29-40.

158. The Hematopoietic PGD2 Synthase Pathway: Synchronizing the inflammatory response and its resolution |Article Library || Cayman Chemical | Supplier [Internet]. [cited 2016 Feb 27]. Available from: https://www.caymanchem.com/article/2140

159. Iñiguez MA, Cacheiro-Llaguno $C$, Cuesta $\mathrm{N}$, Díaz-Muñoz $\mathrm{MD}$, Fresno $\mathrm{M}$. Prostanoid function and cardiovascular disease. Arch Physiol Biochem. 2008 Jul;114(3):201-9. 
160. Arima M, Fukuda T. Prostaglandin D2 and TH2 Inflammation in the Pathogenesis of Bronchial Asthma. Korean J Intern Med. 2011 Mar;26(1):8-18.

161. Oguma T, Asano K, Ishizaka A. Role of Prostaglandin D2 and Its Receptors in the Pathophysiology of Asthma. Allergol Int. 2008;57(4):307-12.

162. Xue L, Salimi M, Panse I, Mjösberg JM, McKenzie ANJ, Spits H, et al. Prostaglandin D2 activates group 2 innate lymphoid cells through chemoattractant receptor-homologous molecule expressed on $\mathrm{TH} 2$ cells. J Allergy Clin Immunol. 2014 Apr;133(4):1184-94.e7.

163. Kim N, Luster AD. Regulation of immune cells by eicosanoid receptors. ScientificWorldJournal. 2007;7:1307-28.

164. Tsubosaka Y, Nakamura T, Hirai H, Hori M, Nakamura M, Ozaki H, et al. A deficiency in the prostaglandin D2 receptor CRTH2 exacerbates adjuvantinduced joint inflammation. J Immunol Baltim Md 1950. 2014 Dec $15 ; 193(12): 5835-40$.

165. Consuegra E de Z, Salgado E de Z, Salgado A de Z. Asma bronquial. Ed. Médica Panamericana; 2003. 720 p.

166. Jandl K, Stacher E, Bálint Z, Sturm EM, Maric J, Peinhaupt M, et al. Activated prostaglandin D2 receptors on macrophages enhance neutrophil recruitment into the lung. J Allergy Clin Immunol. 2016 Jan 11;

167. Luster AD, Tager AM. T-cell trafficking in asthma: lipid mediators grease the way. Nat Rev Immunol. 2004 Sep;4(9):711-24.

168. Pettipher R. The roles of the prostaglandin D2 receptors DP1 and CRTH2 in promoting allergic responses. Br J Pharmacol. 2008 Mar;153(Suppl 1):S191-9.

169. Matsuoka T, Hirata M, Tanaka H, Takahashi Y, Murata T, Kabashima K, et al. Prostaglandin D2 as a mediator of allergic asthma. Science. 2000 Mar 17;287(5460):2013-7.

170. Xue L, Fergusson J, Salimi M, Panse I, Ussher JE, Hegazy AN, et al. Prostaglandin D2 and leukotriene E4 synergize to stimulate diverse TH2 functions and TH2 cell/neutrophil crosstalk. J Allergy Clin Immunol. 2015 May;135(5):1358-66.e1-11.

171. Fajt ML, Gelhaus SL, Freeman B, Uvalle CE, Trudeau JB, Holguin F, et al. Prostaglandin D2 pathway upregulation: Relation to asthma severity, control, and TH2 inflammation. J Allergy Clin Immunol. 2013 Jun;131(6):1504-12.

172. Zhang S, Wu X, Yu S. Prostaglandin D2 Receptor DP2 Mediates Eosinophil trafficking into the Esophagus. Dis Esophagus Off J Int Soc Dis Esophagus ISDE. 2014 Aug;27(6):601-6.

173. Murata T, Aritake K, Tsubosaka Y, Maruyama T, Nakagawa T, Hori M, et al. Anti-inflammatory role of PGD2 in acute lung inflammation and therapeutic 
application of its signal enhancement. Proc Natl Acad Sci U S A. 2013 Mar 26;110(13):5205-10.

174. Kobayashi K, Tsubosaka Y, Hori M, Narumiya S, Ozaki H, Murata T. Prostaglandin D2-DP Signaling Promotes Endothelial Barrier Function via the cAMP/PKA/Tiam1/Rac1 Pathway. Arterioscler Thromb Vasc Biol. 2013 Mar 1;33(3):565-71.

175. Hammad H, Heer HJ de, Soullie T, Hoogsteden HC, Trottein F, Lambrecht BN. Prostaglandin D2 Inhibits Airway Dendritic Cell Migration and Function in Steady State Conditions by Selective Activation of the D Prostanoid Receptor 1. J Immunol. 2003 Oct 15;171(8):3936-40.

176. Matsuoka T, Narumiya S. Prostaglandin Receptor Signaling in Disease. Sci World J. 2007;7:1329-47.

177. Yamamoto Y, Otani S, Hirai H, Nagata K, Aritake K, Urade Y, et al. Dual Functions of Prostaglandin D2 in Murine Contact Hypersensitivity via DP and CRTH2. Am J Pathol. 2011 Jul;179(1):302-14.

178. Monneret G, Gravel S, Diamond M, Rokach J, Powell WS. Prostaglandin D2 is a potent chemoattractant for human eosinophils that acts via a novel DP receptor. Blood. 2001 Sep 15;98(6):1942-8.

179. Yoshimura-Uchiyama C, Iikura M, Yamaguchi $M$, Nagase H, Ishii A, Matsushima K, et al. Differential modulation of human basophil functions through prostaglandin D2 receptors DP and chemoattractant receptorhomologous molecule expressed on Th2 cells/DP2. Clin Exp Allergy J Br Soc Allergy Clin Immunol. 2004 Aug;34(8):1283-90.

180. Kapadia R, Yi J-H, Vemuganti R. Mechanisms of anti-inflammatory and neuroprotective actions of PPAR-gamma agonists. Front Biosci J Virtual Libr. 2008 Jan 1;13:1813-26.

181. Surh Y-J, Na H-K, Park J-M, Lee H-N, Kim W, Yoon I-S, et al. 15-Deoxy$\Delta 12,14$-prostaglandin $\mathrm{J} 2$, an electrophilic lipid mediator of anti-inflammatory and pro-resolving signaling. Biochem Pharmacol. 2011 Nov 15;82(10):1335-51.

182. Koyani CN, Windischhofer W, Rossmann C, Jin G, Kickmaier S, Heinzel FR, et al. 15-deoxy- $\Delta 12,14-\mathrm{PGJ} 2$ promotes inflammation and apoptosis in cardiomyocytes via the DP2/MAPK/TNFa axis. Int J Cardiol. 2014 May 15;173(3):472-80.

183. Cahill KN, Bensko JC, Boyce JA, Laidlaw TM. Prostaglandin D2: A dominant mediator of aspirin exacerbated respiratory disease. J Allergy Clin Immunol. 2015 Jan;135(1):245-52.

184. Nittner-Marszalska M, Cichocka-Jarosz E, Sanak M, Wujczyk M, DorWojnarowska A, Lis G, et al. 9 $\alpha, 11 \beta-P G F 2$, a Prostaglandin D2 Metabolite, as a Marker of Mast Cell Activation in Bee Venom-Allergic Patients. Arch Immunol Ther Exp (Warsz). 2015 Aug;63(4):317-25. 
185. Zhang $\mathrm{X}$, Young HA. PPAR and immune system-what do we know? Int Immunopharmacol. 2002 Jul;2(8):1029-44.

186. Woodward DF, Jones RL, Narumiya S. International Union of Basic and Clinical Pharmacology. LXXXIII: classification of prostanoid receptors, updating 15 years of progress. Pharmacol Rev. 2011 Sep;63(3):471-538.

187. García-Solaesa V, Sanz-Lozano C, Padrón-Morales J, Hernández-Hernández L, García-Sánchez A, Rivera-Reigada ML, et al. The prostaglandin D2 receptor (PTGDR) gene in asthma and allergic diseases. Allergol Immunopathol (Madr). 2014 Feb;42(1):64-8.

188. Narumiya S, Sugimoto Y, Ushikubi F. Prostanoid Receptors: Structures, Properties, and Functions. Physiol Rev. 1999 Jan 10;79(4):1193-226.

189. Neumann E, Khawaja K, Müller-Ladner U. G protein-coupled receptors in rheumatology. Nat Rev Rheumatol. 2014 Jul;10(7):429-36.

190. Cameron L, Webster RB, Strempel JM, Kiesler P, Kabesch M, Ramachandran H, et al. Th2 cell-selective enhancement of human IL13 transcription by IL13$1112 \mathrm{C}>\mathrm{T}$, a polymorphism associated with allergic inflammation. J Immunol Baltim Md 1950. 2006 Dec 15;177(12):8633-42.

191. PTGDR - Prostaglandin D2 receptor - Homo sapiens (Human) - PTGDR gene \& protein [Internet]. [cited 2016 Feb 27]. Available from: http://www.uniprot.org/uniprot/Q13258

192. Mohan S, Ahmad AS, Glushakov AV, Chambers C, Doré S. Putative Role of Prostaglandin Receptor in Intracerebral Hemorrhage. Front Neurol [Internet]. 2012 Oct 22 [cited 2016 Feb 28];3. Available from: http://www.ncbi.nlm.nih.gov/pmc/articles/PMC3477820/

193. Hakonarson H, Bjornsdottir US, Halapi E, Palsson S, Adalsteinsdottir E, Gislason D, et al. A Major Susceptibility Gene for Asthma Maps to Chromosome 14q24. Am J Hum Genet. 2002 Sep;71(3):483-91.

194. Mansur A, Bishop D, Holgate S, Markham A, Morrison J. Linkage/association study of a locus modulating total serum IgE on chromosome $14 \mathrm{q} 13-24$ in families with asthma. Thorax. 2004 Oct;59(10):876-82.

195. Mansur AH, Bishop DT, Markham AF, Morton NE, Holgate ST, Morrison JF. Suggestive evidence for genetic linkage between $\operatorname{IgE}$ phenotypes and chromosome 14q markers. Am J Respir Crit Care Med. 1999 Jun;159(6):1796802.

196. Malerba G, Pignatti PF. A review of asthma genetics: gene expression studies and recent candidates. J Appl Genet. 2005;46(1):93-104.

197. Oguma T, Palmer LJ, Birben E, Sonna LA, Asano K, Lilly CM. Role of prostanoid DP receptor variants in susceptibility to asthma. N Engl J Med. 2004 Oct 21;351(17):1752-63. 
198. Sanz C, Isidoro-García M, Dávila I, Moreno E, Laffond E, Avila C, et al. Promoter genetic variants of prostanoid DP receptor (PTGDR) gene in patients with asthma. Allergy. 2006 May;61(5):543-8.

199. Sanz C, Isidoro-García M, Dávila I, De Pedro MP, De Arriba Méndez S, Padrón $\mathrm{J}$, et al. A new PTGDR promoter polymorphism in a population of children with asthma. Pediatr Allergy Immunol. 2009 Mar 1;20(2):151-6.

200. Benito Pescador D, Isidoro-García M, García-Solaesa V, Pascual de Pedro M, Sanz C, Hernández-Hernández L, et al. Genetic association study in nasal polyposis. J Investig Allergol Clin Immunol. 2012;22(5):331-40.

201. Zhu G, Vestbo J, Lenney W, Silverman M, Whyte M, Helms P, et al. Association of PTGDR gene polymorphisms with asthma in two Caucasian populations. Genes Immun. 2007 Jul;8(5):398-403.

202. Karmaus W, Ziyab AH, Everson T, Holloway JW. Epigenetic mechanisms and models in the origins of asthma. Curr Opin Allergy Clin Immunol. 2013 Feb;13(1):63-9.

203. Isidoro-García M, Sanz C, García-Solaesa V, Pascual M, Pescador DB, Lorente F, et al. PTGDR gene in asthma: a functional, genetic, and epigenetic study. Allergy. 2011 Dec;66(12):1553-62.

204. Tsai YJ, Choudhry S, Kho J, Beckman K, Tsai H-J, Navarro D, et al. The PTGDR gene is not associated with asthma in 3 ethnically diverse populations. $\mathbf{J}$ Allergy Clin Immunol. 2006 Dec;118(6):1242-8.

205. Li J, Liu Q, Wang P, Li H, Wei C, Guo C, et al. Lack of association between three promoter polymorphisms of PTGDR gene and asthma in a Chinese Han population. Int J Immunogenet. 2007 Oct;34(5):353-7.

206. Leung TF, Li CY, Kong APS, Chan IHS, Ng MCY, Chan MHM, et al. PTGDR is not a major candidate gene for asthma and atopy in Chinese children. Pediatr Allergy Immunol Off Publ Eur Soc Pediatr Allergy Immunol. 2009 Sep;20(6):556-62.

207. Birbian N, Singh J, Jindal SK, Joshi A, Batra N. No association of PTGDR $441 \mathrm{C} / \mathrm{T}$ polymorphism with asthma in a North Indian population. Dis Markers. 2011;31(6):353-9.

208. Katsumata Y, Shinmura K, Sugiura Y, Tohyama S, Matsuhashi T, Ito H, et al. Endogenous prostaglandin D2 and its metabolites protect the heart against ischemia-reperfusion injury by activating Nrf2. Hypertension. 2014 Jan;63(1):80-7.

209. Lim W, Park C, Shim MK, Lee YH, Lee YM, Lee Y. Glucocorticoids suppress hypoxia-induced COX-2 and hypoxia inducible factor- $1 \alpha$ expression through the induction of glucocorticoidinduced leucine zipper. Br J Pharmacol. 2014 Feb;171(3):735-45. 
210. Yamaura K, Doi R, Suwa E, Ueno K. Repeated application of glucocorticoids exacerbate pruritus via inhibition of prostaglandin D2 production of mast cells in a murine model of allergic contact dermatitis. J Toxicol Sci. 2012;37(6):1127-34.

211. Lajqi N, Ilazi A, Kastrati B, Islami H. Comparison of Glucocorticoid (Budesonide) and Antileukotriene (Montelukast) Effect in Patients with Bronchial Asthma Determined with Body Plethysmography. Acta Inform Medica. 2015 Dec;23(6):347-51.

212. Paakinaho V, Kaikkonen S, Levonen A-L, Palvimo JJ. Electrophilic Lipid Mediator 15-Deoxy- $\Delta$ 12,14-Prostaglandin J2 Modifies Glucocorticoid Signaling via Receptor SUMOylation. Mol Cell Biol. 2014 Sep;34(17):3202-13.

213. Kang M-J, Kwon J-W, Kim B-J, Yu J, Choi W-A, Shin Y-J, et al. Polymorphisms of the PTGDR and LTC4S influence responsiveness to leukotriene receptor antagonists in Korean children with asthma. J Hum Genet. 2011 Apr;56(4):284-9.

214. Livak K, Schmittgen T. Guide to Performing Relative Quantification of Gene Expression Using Real-Time Quatitative PCR. Applied Biosystems; 2004.

215. 260/280 and 260/230 Ratios. Technical bulletin. Thermo scientific. [Internet]. [cited 2015 Dec 19]. Available from: http://www.nanodrop.com/Library/T009NanoDrop\%201000-\&-NanoDrop\%208000-Nucleic-Acid-Purity-Ratios.pdf

216. HT ExoSAP-IT High-Throughput PCR Product Cleanup | Affymetrix [Internet]. [cited 2016 May 13]. Available from: http://www.affymetrix.com/catalog/prod460001/USB/HT+ExoSAP-IT+HighThroughput+PCR+Product+Cleanup\#1_1

217. A549 Cell Line Transfection Protocol Reagent Method [Internet]. [cited 2016 Jan 22]. Available from: http://www.a549.com/

218. Masubuchi T, Koyama S, Sato E, Takamizawa A, Kubo K, Sekiguchi M, et al. Smoke extract stimulates lung epithelial cells to release neutrophil and monocyte chemotactic activity. Am J Pathol. 1998 Dec;153(6):1903-12.

219. Corbière V, Dirix V, Norrenberg S, Cappello M, Remmelink M, Mascart F. Phenotypic characteristics of human type II alveolar epithelial cells suitable for antigen presentation to T lymphocytes. Respir Res. 2011;12:15.

220. McCormick C, Freshney RI, Speirs V. Activity of interferon alpha, interleukin 6 and insulin in the regulation of differentiation in A549 alveolar carcinoma cells. Br J Cancer. 1995 Feb;71(2):232-9.

221. Dave KA, Norris EL, Bukreyev AA, Headlam MJ, Buchholz UJ, Singh T, et al. A comprehensive proteomic view of responses of A549 type II alveolar epithelial cells to human respiratory syncytial virus infection. Mol Cell Proteomics MCP. 2014 Dec;13(12):3250-69. 
222. Montalbano AM, Riccobono L, Siena L, Chiappara G, Di Sano C, Anzalone G, et al. Cigarette smoke affects IL-17A, IL-17F and IL-17 receptor expression in the lung tissue: Ex vivo and in vitro studies. Cytokine. 2015 Dec;76(2):391-402.

223. Pniewska E, Sokolowska M, Kupryś-Lipińska I, Przybek M, Kuna P, Pawliczak $\mathrm{R}$. The step further to understand the role of cytosolic phospholipase A2 alpha and group X secretory phospholipase A2 in allergic inflammation: pilot study. BioMed Res Int. 2014;2014:670814.

224. Murai H, Okazaki S, Hayashi H, Kawakita A, Hosoki K, Yasutomi M, et al. Alternaria extract activates autophagy that induces IL-18 release from airway epithelial cells. Biochem Biophys Res Commun. 2015 Sep 4;464(4):969-74.

225. Rajajendram R, Tham CL, Akhtar MN, Sulaiman MR, Israf DA. Inhibition of Epithelial CC-Family Chemokine Synthesis by the Synthetic Chalcone DMPF-1 via Disruption of NF- $\kappa$ B Nuclear Translocation and Suppression of Experimental Asthma in Mice. Mediators Inflamm. 2015;2015:176926.

226. Chen S-M, Tsai Y-S, Lee S-W, Liu Y-H, Liao S-K, Chang W-W, et al. Astragalus membranaceus modulates Th1/2 immune balance and activates PPAR $\gamma$ in a murine asthma model. Biochem Cell Biol Biochim Biol Cell. 2014 Oct;92(5):397-405.

227. Freshney RI. Culture of Animal Cells: A Manual of Basic Technique and Specialized Applications. John Wiley \& Sons; 2011. 57-71 p.

228. Strober W. Trypan Blue Exclusion Test of Cell Viability. Curr Protoc Immunol Ed John E Coligan Al. 2015;111:A3.B.1-3.

229. Netto C, Soccol VT, Sepulveda LM, Timenetsky J. Experimental infection of BHK21 and Vero cell lines with different Mycoplasma spp. Braz J Microbiol Publ Braz Soc Microbiol. 2014;45(4):1513-9.

230. Geraghty RJ, Capes-Davis A, Davis JM, Downward J, Freshney RI, Knezevic I, et al. Guidelines for the use of cell lines in biomedical research. $\mathrm{Br} \mathrm{J}$ Cancer. 2014 Sep 9;111(6):1021-46.

231. Maurisse R, De Semir D, Emamekhoo H, Bedayat B, Abdolmohammadi A, Parsi $\mathrm{H}$, et al. Comparative transfection of DNA into primary and transformed mammalian cells from different lineages. BMC Biotechnol. 2010 Feb 8;10:9.

232. Lipofectamine ${ }^{\circledR}$ Reagent for the transfection of DNA into eukaryotic cells [Internet]. [cited 2016 Jan 22]. Available from: https://www.thermofisher.com/es/en/home/references/protocols/cellculture/transfection-protocol/lipofectamine-reagent-suitable-for-the-transfectionof-dna-into-eukaryotic-cells.html

233. How xMAP® Technology Works [Internet]. [cited 2016 Jan 25]. Available from: https://www.thermofisher.com/es/en/home/references/protein-analysisguide/multiplex-assays-luminex-assays/how-xmap-technology-works.html 
234. Datta SC, Opp MR. Lipopolysaccharide-induced increases in cytokines in discrete mouse brain regions are detectable using Luminex xMAP® technology. J Neurosci Methods. 2008 Oct 30;175(1):119-24.

235. BIO-RAD. Bio-Plex Cytokine Assay. Instruction Manual.

236. Gueders MM, Paulissen G, Crahay C, Quesada-Calvo F, Hacha J, Hove CV, et al. Mouse models of asthma: a comparison between C57BL/6 and BALB/c strains regarding bronchial responsiveness, inflammation, and cytokine production. Inflamm Res. 2009 Jun 9;58(12):845-54.

237. Moore CD, Roberts JK, Orton CR, Murai T, Fidler TP, Reilly CA, et al. Metabolic pathways of inhaled glucocorticoids by the CYP3A enzymes. Drug Metab Dispos Biol Fate Chem. 2013 Feb;41(2):379-89.

238. Hukkanen J, Väisänen T, Lassila A, Piipari R, Anttila S, Pelkonen O, et al. Regulation of CYP3A5 by glucocorticoids and cigarette smoke in human lungderived cells. J Pharmacol Exp Ther. 2003 Feb;304(2):745-52.

239. Roberts JK, Moore CD, Romero EG, Ward RM, Yost GS, Reilly CA. Regulation of CYP3A genes by glucocorticoids in human lung cells. F1000Research [Internet]. 2013 Oct 8 [cited 2016 Jan 25];2. Available from: http://www.ncbi.nlm.nih.gov/pmc/articles/PMC3869485/

240. Hukkanen J, Lassila A, Päivärinta K, Valanne S, Sarpo S, Hakkola J, et al. Induction and regulation of xenobiotic-metabolizing cytochrome P450s in the human A549 lung adenocarcinoma cell line. Am J Respir Cell Mol Biol. 2000 Mar;22(3):360-6.

241. Żochowska D, Wyzgał J, Pączek L. Impact of CYP3A4*1B and CYP3A5*3 polymorphisms on the pharmacokinetics of cyclosporine and sirolimus in renal transplant recipients. Ann Transplant. 2012 Sep;17(3):36-44.

242. Roberts JK, Moore CD, Ward RM, Yost GS, Reilly CA. Metabolism of Beclomethasone Dipropionate by Cytochrome P450 3A Enzymes. J Pharmacol Exp Ther. 2013 May;345(2):308-16.

243. Awasthi S, Gupta S, Agarwal S, Sharma N. CRHR1 Gene SNPs and Response to Systemic Corticosteroids in Indian Asthmatic Children During Acute Exacerbation. Indian J Pediatr. 2015 Sep;82(9):781-6.

244. Vijverberg SJH, Koster ES, Tavendale R, Leusink M, Koenderman L, Raaijmakers J a. M, et al. ST13 polymorphisms and their effect on exacerbations in steroid-treated asthmatic children and young adults. Clin Exp Allergy J Br Soc Allergy Clin Immunol. 2015 Jun;45(6):1051-9.

245. Kim M-H, Kim S-H, Kim Y-K, Hong S-J, Min K-U, Cho S-H, et al. A polymorphism in the histone deacetylase 1 gene is associated with the response to corticosteroids in asthmatics. Korean J Intern Med. 2013 Nov;28(6):708-14. 
246. Lopert A, Rijavec M, Zavbi M, Korošec P, Fležar M. Asthma treatment outcome in adults is associated with rs9910408 in TBX21 gene. Sci Rep. 2013;3:2915.

247. Berce V, Kozmus CEP, Potočnik U. Association among ORMDL3 gene expression, 17q21 polymorphism and response to treatment with inhaled corticosteroids in children with asthma. Pharmacogenomics J. 2013 Dec;13(6):523-9.

248. Dijkstra A, Postma DS, Bruinenberg M, van Diemen CC, Boezen HM, Koppelman GH, et al. SERPINE1 -675 GG/5G polymorphism is associated with asthma severity and inhaled corticosteroid response. Eur Respir J. 2011 Nov;38(5):1036-43.

249. Berce V, Potocnik U. Functional polymorphism in CTLA4 gene influences the response to therapy with inhaled corticosteroids in Slovenian children with atopic asthma. Biomark Biochem Indic Expo Response Susceptibility Chem. 2010 Mar;15(2):158-66.

250. de Vooght KMK, van Wijk R, van Solinge WW. GATA-1 binding sites in exon 1 direct erythroid-specific transcription of PPOX. Gene. 2008 Feb 15;409(1-2):8391.

251. Pierce RA, Moore $\mathrm{CH}$, Arikan MC. Positive transcriptional regulatory element located within exon 1 of elastin gene. Am J Physiol Lung Cell Mol Physiol. 2006 Sep;291(3):L391-9.

252. Bengtsen M, Klepper K, Gundersen S, Cuervo I, Drabløs F, Hovig E, et al. cMyb Binding Sites in Haematopoietic Chromatin Landscapes. PloS One. 2015;10(7):e0133280.

253. Ahituv N. Exonic enhancers: proceed with caution in exome and genome sequencing studies. Genome Med. 2016;8(1):14.

254. Hirsch N, Birnbaum RY. Dual Function of DNA Sequences: Protein-Coding Sequences Function as Transcriptional Enhancers. Perspect Biol Med. 2015;58(2):182-95.

255. Khan AH, Lin A, Smith DJ. Discovery and characterization of human exonic transcriptional regulatory elements. PloS One. 2012;7(9):e46098.

256. Jamrozik EF, Warrington N, McClenaghan J, Hui J, Musk AW, James A, et al. Functional haplotypes in the PTGDR gene fail to associate with asthma in two Australian populations. Respirol Carlton Vic. 2011 Feb;16(2):359-66.

257. Tapani E, Taavitsainen M, Lindros K, Vehmas T, Lehtonen E. Toxicity of ethanol in low concentrations. Experimental evaluation in cell culture. Acta Radiol Stockh Swed 1987. 1996 Nov;37(6):923-6.

258. Castilla R, González R, Fouad D, Fraga E, Muntané J. Dual effect of ethanol on cell death in primary culture of human and rat hepatocytes. Alcohol Alcohol Oxf Oxfs. 2004 Aug;39(4):290-6. 
259. Wu D, Zhai Q, Shi X. Alcohol-induced oxidative stress and cell responses. J Gastroenterol Hepatol. 2006 Oct;21 Suppl 3:S26-9.

260. Relja B, Omid N, Wagner N, Mörs K, Werner I, Juengel E, et al. Ethanol, ethyl and sodium pyruvate decrease the inflammatory responses of human lung epithelial cells via Akt and $\mathrm{NF}-\kappa \mathrm{B}$ in vitro but have a low impact on hepatocellular cells. Int J Mol Med. 2016 Feb;37(2):517-25.

261. Johansson A-SM, Lidén J, Okret S, Palmblad JEW. Effects of ethanol on cytokine generation and NFKB activity in human lung epithelial cell. Biochem Pharmacol. 2005 Aug 15;70(4):545-51.

262. Sakazaki F, Ogino H, Arakawa T, Okuno T, Ueno H. Low-dose ethanol aggravates allergic dermatitis in mice. Alcohol Fayettev N. 2014 Aug;48(5):5018 .

263. Bouchard JC, Kim J, Beal DR, Vaickus LJ, Craciun FL, Remick DG. Acute Oral Ethanol Exposure Triggers Asthma In Cockroach Allergen-Sensitized Mice. Am J Pathol. 2012 Sep;181(3):845-57.

264. Bouchard JC, Beal DR, Kim J, Vaickus LJ, Remick DG. Chemokines mediate ethanol-induced exacerbations of murine cockroach allergen asthma. Clin Exp Immunol. 2013 May;172(2):203-16.

265. Miranda TB, Morris SA, Hager GL. Complex genomic interactions in the dynamic regulation of transcription by the glucocorticoid receptor. Mol Cell Endocrinol. 2013 Nov 5;380(1-2):16-24.

266. John S, Johnson TA, Sung M-H, Biddie SC, Trump S, Koch-Paiz CA, et al. Kinetic Complexity of the Global Response to Glucocorticoid Receptor Action. Endocrinology. 2009 Apr;150(4):1766-74.

267. Lang G, Gombert WM, Gould HJ. A transcriptional regulatory element in the coding sequence of the human Bcl-2 gene. Immunology. 2005 Jan;114(1):25-36.

268. Dambara A, Morinaga T, Fukuda N, Yamakawa Y, Kato T, Enomoto A, et al. Nucleolin modulates the subcellular localization of GDNF-inducible zinc finger protein 1 and its roles in transcription and cell proliferation. Exp Cell Res. 2007 Oct 15;313(17):3755-66.

269. Stogios PJ, Downs GS, Jauhal JJS, Nandra SK, Privé GG. Sequence and structural analysis of BTB domain proteins. Genome Biol. 2005;6(10):R82.

270. Lee S-H, Jang M-K, Kim O-S, Lee O-H, Kim NY, Yoo K-H, et al. Activation of the GDNF-inducible transcription factor (GIF) gene promoter by glucocorticoid and progesterone. J Steroid Biochem Mol Biol. 2009 May;115(1-2):30-5.

271. Thu KL, Becker-Santos DD, Radulovich N, Pikor LA, Lam WL, Tsao M-S. SOX15 and other SOX family members are important mediators of tumorigenesis in multiple cancer types. Oncoscience. 2014;1(5):326-35. 
272. Tsuchiya M, Misaka R, Nitta K, Tsuchiya K. Transcriptional factors, Mafs and their biological roles. World J Diabetes. 2015 Feb 15;6(1):175-83.

273. Sato M, Shibata Y, Kimura T, Yamauchi K, Abe S, Inoue S, et al. Immunohistochemical staining for transcription factor MafB in alveolar macrophages is correlated with spirometric measures of airflow limitation in smokers. Respirol Carlton Vic. 2011 Jan;16(1):124-30.

274. Machiya J-I, Shibata Y, Yamauchi K, Hirama N, Wada T, Inoue S, et al. Enhanced expression of MafB inhibits macrophage apoptosis induced by cigarette smoke exposure. Am J Respir Cell Mol Biol. 2007 Apr;36(4):418-26.

275. Grenningloh R, Gho A, Lucia P di, Klaus M, Bollag W, Ho I-C, et al. Cutting Edge: Inhibition of the Retinoid X Receptor (RXR) Blocks $\mathrm{T}$ Helper 2 Differentiation and Prevents Allergic Lung Inflammation. J Immunol. 2006 May 1;176(9):5161-6.

276. Hejazi ME, Modarresi-Ghazani F, Entezari-Maleki T. A review of Vitamin D effects on common respiratory diseases: Asthma, chronic obstructive pulmonary disease, and tuberculosis. J Res Pharm Pract. 2016;5(1):7-15.

277. Wu J, Zhang Y, Liu Q, Zhong W, Xia Z. All-trans retinoic acid attenuates airway inflammation by inhibiting Th2 and Th17 response in experimental allergic asthma. BMC Immunol. 2013;14:28.

278. Yang H, Wang H. Signaling control of the constitutive androstane receptor (CAR). Protein Cell. 2014 Feb;5(2):113-23.

279. Pascussi JM, Busson-Le Coniat M, Maurel P, Vilarem M-J. Transcriptional analysis of the orphan nuclear receptor constitutive androstane receptor (NR1I3) gene promoter: identification of a distal glucocorticoid response element. Mol Endocrinol Baltim Md. 2003 Jan;17(1):42-55.

280. Pascussi JM, Gerbal-Chaloin S, Fabre JM, Maurel P, Vilarem MJ. Dexamethasone enhances constitutive androstane receptor expression in human hepatocytes: consequences on cytochrome P450 gene regulation. Mol Pharmacol. 2000 Dec;58(6):1441-50.

281. Mahon BD, Wittke A, Weaver V, Cantorna MT. The targets of vitamin D depend on the differentiation and activation status of CD4 positive $\mathrm{T}$ cells. J Cell Biochem. 2003 Aug 1;89(5):922-32.

282. Hamers AAJ, Argmann C, Moerland PD, Koenis DS, Marinković G, Sokolović $\mathrm{M}$, et al. Nur77-deficiency in bone marrow-derived macrophages modulates inflammatory responses, extracellular matrix homeostasis, phagocytosis and tolerance. BMC Genomics. 2016;17(1):162.

283. Hanna RN, Shaked I, Hubbeling HG, Punt JA, Wu R, Herrley E, et al. NR4A1 (Nur77) deletion polarizes macrophages toward an inflammatory phenotype and increases atherosclerosis. Circ Res. 2012 Feb 3;110(3):416-27. 
284. Koch S, Graser A, Mirzakhani H, Zimmermann T, Melichar VO, Wölfel M, et al. Increased expression of nuclear factor of activated T cells 1 drives IL-9-mediated allergic asthma. J Allergy Clin Immunol [Internet]. 2016 Mar 15 [cited 2016 Apr 10];0(0). Available from: http://www.jacionline.org/article/S0091674916002001/abstract

285. Diehl S, Krahl T, Rinaldi L, Norton R, Irvin CG, Rincón M. Inhibition of NFAT specifically in $\mathrm{T}$ cells prevents allergic pulmonary inflammation. $\mathrm{J}$ Immunol Baltim Md 1950. 2004 Mar 15;172(6):3597-603.

286. Fink K, Grandvaux N. STAT2 and IRF9: Beyond ISGF3. JAK-STAT. 2013 Oct $1 ; 2(4): \mathrm{e} 27521$.

287. Gonzales-van Horn SR, Farrar JD. Interferon at the crossroads of allergy and viral infections. J Leukoc Biol. 2015 Aug;98(2):185-94.

288. DeKoter RP, Schweitzer BL, Kamath MB, Jones D, Tagoh H, Bonifer C, et al. Regulation of the interleukin-7 receptor alpha promoter by the Ets transcription factors PU.1 and GA-binding protein in developing B cells. J Biol Chem. 2007 May 11;282(19):14194-204.

289. Gallant S, Gilkeson G. ETS transcription factors and regulation of immunity. Arch Immunol Ther Exp (Warsz). 2006 Jun;54(3):149-63.

290. Tharappel JC, Cholewa J, Espandiari P, Spear BT, Gairola CG, Glauert HP. Effects of cigarette smoke on the activation of oxidative stress-related transcription factors in female A/J mouse lung. J Toxicol Environ Health A. 2010;73(19):1288-97.

291. Hellqvist M, Mahlapuu M, Blixt Å, Enerbäck S, Carlsson P. The Human Forkhead Protein FREAC-2 Contains Two Functionally Redundant Activation Domains and Interacts with TBP and TFIIB. J Biol Chem. 1998 Sep $4 ; 273(36): 23335-43$.

292. Mukhopadhyay S, Mukherjee S, Ray BK, Ray A, Stone WL, Das SK. Antioxidant liposomes protect against CEES-induced lung injury by decreasing SAF-1/MAZ-mediated inflammation in the guinea pig lung. J Biochem Mol Toxicol. 2010 Jun;24(3):187-94.

293. Ray A, Dhar S, Shakya A, Ray P, Okada Y, Ray BK. SAF-3, a novel splice variant of the SAF-1/MAZ/Pur-1 family, is expressed during inflammation. FEBS J. 2009 Aug;276(15):4276-86.

294. Suehiro T, Kaneda T, Ikeda Y, Arii K, Kumon Y, Hashimoto K. Regulation of human glucocorticoid receptor gene transcription by Sp1 and p53. Mol Cell Endocrinol. 2004 Jul 30;222(1-2):33-40.

295. Kolla V, Litwack G. Upregulation of mineralocorticoid- and glucocorticoidreceptor gene expression by Sp-I. Mol Cell Biol Res Commun MCBRC. 1999 Apr;1(1):44-7. 
296. Hahm K, Ernst P, Lo K, Kim GS, Turck C, Smale ST. The lymphoid transcription factor LyF-1 is encoded by specific, alternatively spliced mRNAs derived from the Ikaros gene. Mol Cell Biol. 1994 Nov;14(11):7111-23.

297. Taylor A, Tang W, Bruscia EM, Zhang P-X, Lin A, Gaines P, et al. SRF is required for neutrophil migration in response to inflammation. Blood. 2014 May 8;123(19):3027-36.

298. Taylor A, Halene S. The regulatory role of serum response factor pathway in neutrophil inflammatory response. Curr Opin Hematol. 2015 Jan;22(1):67-73.

299. Miano JM. Role of serum response factor in the pathogenesis of disease. Lab Invest. 2010 Sep;90(9):1274-84.

300. Xue L, Gyles SL, Wettey FR, Gazi L, Townsend E, Hunter MG, et al. Prostaglandin D2 causes preferential induction of proinflammatory Th2 cytokine production through an action on chemoattractant receptor-like molecule expressed on Th2 cells. J Immunol Baltim Md 1950. 2005 Nov 15;175(10):65316.

301. Medoff BD, Sauty A, Tager AM, Maclean JA, Smith RN, Mathew A, et al. IFN$\gamma$-Inducible Protein 10 (CXCL10) Contributes to Airway Hyperreactivity and Airway Inflammation in a Mouse Model of Asthma. J Immunol. 2002 May 15;168(10):5278-86.

302. Deshmane SL, Kremlev S, Amini S, Sawaya BE. Monocyte Chemoattractant Protein-1 (MCP-1): An Overview. J Interferon Cytokine Res. 2009 Jun;29(6):313-26.

303. Baay-Guzman GJ, Bebenek IG, Zeidler M, Hernandez-Pando R, Vega MI, Garcia-Zepeda EA, et al. HIF-1 expression is associated with CCL2 chemokine expression in airway inflammatory cells: implications in allergic airway inflammation. Respir Res. 2012;13(1):60.

304. Singh SR, Sutcliffe A, Kaur D, Gupta S, Desai D, Saunders R, et al. CCL2 release by airway smooth muscle is increased in asthma and promotes fibrocyte migration. Allergy. 2014 Sep;69(9):1189-97.

305. Chihara J, Yasuba H, Tsuda A, Urayama O, Saito N, Honda K, et al. Elevation of the plasma level of RANTES during asthma attacks. J Allergy Clin Immunol. 1997 Dec;100(6 Pt 2):S52-5.

306. Takyar S, Vasavada H, Zhang J, Ahangari F, Niu N, Liu Q, et al. VEGF controls lung Th2 inflammation via the miR-1-Mpl (myeloproliferative leukemia virus oncogene)-P-selectin axis. J Exp Med. 2013 Sep 23;210(10):1993-2010.

307. Hosoki K, Ying S, Corrigan C, Qi H, Kurosky A, Jennings K, et al. Analysis of a Panel of 48 Cytokines in BAL Fluids Specifically Identifies IL-8 Levels as the Only Cytokine that Distinguishes Controlled Asthma from Uncontrolled Asthma, and Correlates Inversely with FEV1. PLoS ONE [Internet]. 2015 May 26 [cited 
2016

Apr

11];10(5).

Available

from:

http://www.ncbi.nlm.nih.gov/pmc/articles/PMC4444276/

308. Zhou ZH, Han Y, Wei T, Aras S, Chaturvedi P, Tyler S, et al. Regulation of monocyte chemoattractant protein (MCP)-1 transcription by interferon-gamma (IFN-gamma) in human astrocytoma cells: postinduction refractory state of the gene, governed by its upstream elements. FASEB J Off Publ Fed Am Soc Exp Biol. 2001 Feb;15(2):383-92.

309. Herbert C, Hettiaratchi A, Webb DC, Thomas PS, Foster PS, Kumar RK. Suppression of cytokine expression by roflumilast and dexamethasone in a model of chronic asthma. Clin Exp Allergy J Br Soc Allergy Clin Immunol. 2008 May;38(5):847-56.

310. Djalilian AR, Nagineni CN, Mahesh SP, Smith JA, Nussenblatt RB, Hooks JJ. Inhibition of inflammatory cytokine production in human corneal cells by dexamethasone, but not cyclosporin. Cornea. 2006 Jul;25(6):709-14.

311. Zhan Y, Zou S, Hua F, Li F, Ji L, Wang W, et al. High-dose dexamethasone modulates serum cytokine profile in patients with primary immune thrombocytopenia. Immunol Lett. 2014 Jul;160(1):33-8.

312. Barnes PJ, Drazen JM, Rennard SI. Asthma and COPD: Basic Mechanisms and Clinical Management. Academic Press; 2009. 898 p.

313. Murakami R, Nakagawa Y, Shimizu M, Wakabayashi A, Negishi Y, Hiroi T, et al. Effects of Dendritic Cell Subset Manipulation on Airway Allergy in a Mouse Model. Int Arch Allergy Immunol. 2015;168(4):219-32.

314. Lee L-F, Axtell R, Tu GH, Logronio K, Dilley J, Yu J, et al. IL-7 Promotes TH1 Cell Differentiation and Its Level in Serum Predicts Response to Interferon- $\beta$ in Multiple Sclerosis. Sci Transl Med. 2011 Jul 27;3(93):93ra68.

315. Jin J-O, Kawai T, Cha S, Yu Q. Interleukin-7 Enhances the Th1 Response to Promote the Development of Sjögren's Syndrome-like Autoimmune Exocrinopathy in Mice. Arthritis Rheum. 2013 Aug 1;65(8):2132-42.

316. Lee CG, Ma B, Takyar S, Ahangari F, DelaCruz C, He CH, et al. Studies of Vascular Endothelial Growth Factor in Asthma and Chronic Obstructive Pulmonary Disease. Proc Am Thorac Soc. 2011 Nov 1;8(6):512-5.

317. Bandi N, Kompella UB. Budesonide reduces vascular endothelial growth factor secretion and expression in airway (Calu-1) and alveolar (A549) epithelial cells. Eur J Pharmacol. 2001 Aug 10;425(2):109-16.

318. Bartneck M, Peters FM, Warzecha KT, Bienert M, van Bloois L, Trautwein C, et al. Liposomal encapsulation of dexamethasone modulates cytotoxicity, inflammatory cytokine response, and migratory properties of primary human macrophages. Nanomedicine Nanotechnol Biol Med. 2014 Aug;10(6):1209-20. 
319. Kim V, Cornwell WD, Oros M, Durra H, Criner GJ, Rogers TJ. Plasma Chemokine signature correlates with lung goblet cell hyperplasia in smokers with and without chronic obstructive pulmonary disease. BMC Pulm Med. 2015;15:111.

320. Grob M, Schmid-Grendelmeier P, Joller-Jemelka HI, Ludwig E, Dubs RW, Grob $\mathrm{PJ}$, et al. Altered intracellular expression of the chemokines MIP-1alpha, MIP1 beta and IL- 8 by peripheral blood CD4+ and CD8+ T cells in mild allergic asthma. Allergy. 2003 Mar;58(3):239-45.

321. Schrum S, Probst P, Fleischer B, Zipfel PF. Synthesis of the CC-chemokines MIP-1alpha, MIP-1beta, and RANTES is associated with a type 1 immune response. J Immunol. 1996 Oct 15;157(8):3598-604.

322. Pease JE, Williams TJ. Eotaxin and asthma. Curr Opin Pharmacol. 2001 Jun;1(3):248-53.

323. CORRIGAN CJ. Eotaxin and asthma: some answers, more questions. Clin Exp Immunol. 1999 Apr;116(1):1-3.

324. Chen Y-L, Chiang B-L. Targeting TSLP With shRNA Alleviates Airway Inflammation and Decreases Epithelial CCL17 in a Murine Model of Asthma. Mol Ther Nucleic Acids. 2016;5:e316.

325. Shin YS, Takeda K, Gelfand EW. Understanding asthma using animal models. Allergy Asthma Immunol Res. 2009 Oct;1(1):10-8.

326. Reddy AT, Lakshmi SP, Reddy RC. Murine model of allergen induced asthma. J Vis Exp JoVE. 2012;(63):e3771.

327. Nials AT, Uddin S. Mouse models of allergic asthma: acute and chronic allergen challenge. Dis Model Mech. 2008;1(4-5):213-20. 


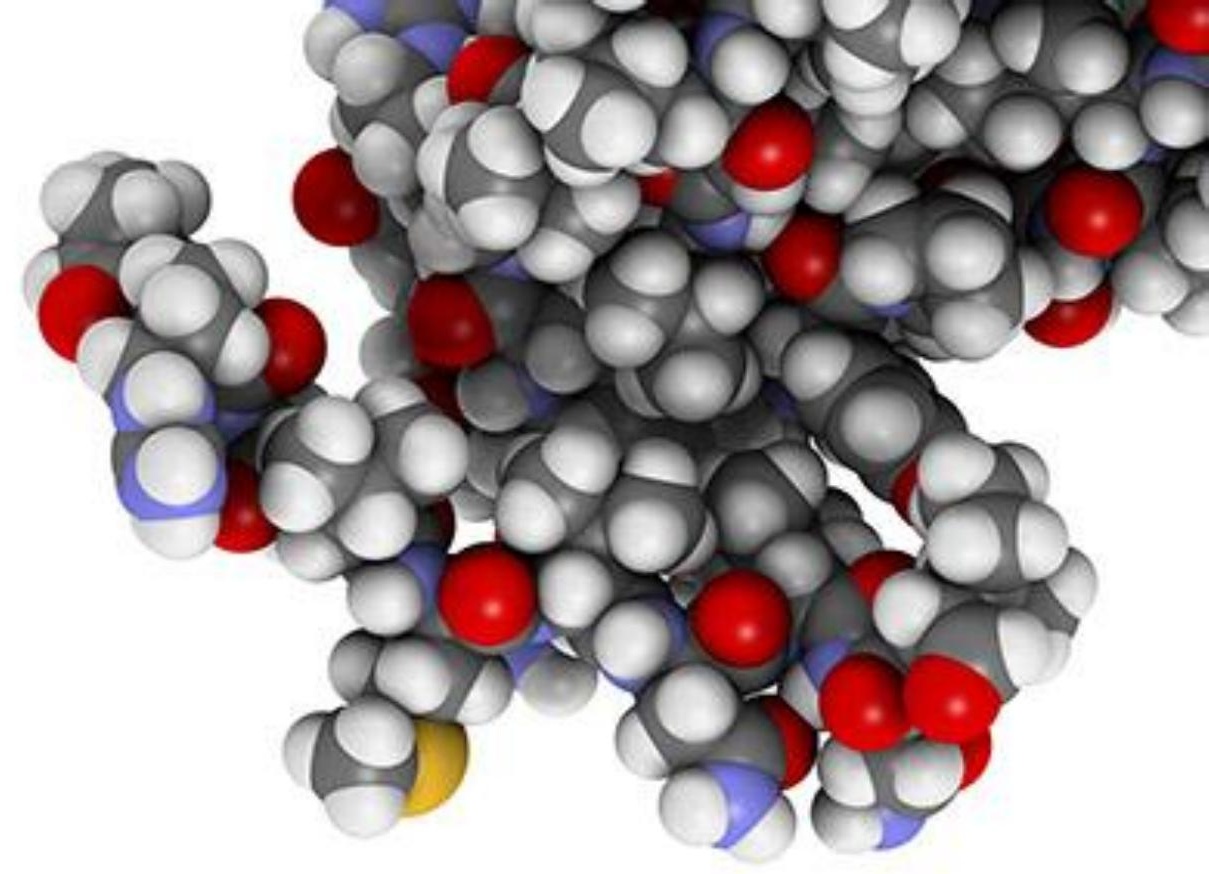

ÍNDICE DE TABLAS 



\section{9. ÍNDICE DE TABLAS}

Tabla 1: Clasificación de los glucocorticoides.

Tabla 2: Relación de algunas de las citocinas implicadas en la patología asmática y sus efectos 36

Tabla 3: Características clínicas y biológicas de los fenotipos del asma grave del adulto.

Tabla 4: Programa de amplificación por PCR utilizado. .81

Tabla 5: Programa de amplificación en los ensayos de PCR a tiempo real. 85

Tabla 6: Secuencias de los cebadores utilizados en los diferentes ensayos. 88

Tabla 7: Números de referencia (rs) de los polimorfismos de PTGDR a estudio. 91

Tabla 8: Especificaciones metodológicas de los distintos ensayos. 107

Tabla 9: Especificaciones para la lipofección en los diferentes ensayos. 110

Tabla 10: Programa utilizado para el ensayo de luciferasa en el luminómetro 113

Tabla 11: Panel de citocinas detectadas en el ensayo. 118

Tabla 12: Resultados del análisis in silico del promotor de PTGDR con las plataformas de MatInspector y Transfac (Biobase). 144

Tabla 13: Patrón de citocinas expresadas a 12 horas sin tratamiento. 147

Tabla 14: Patrón de expresión de citocinas a las 36 horas sin tratamiento 149 
Efecto de la dexametasona sobre el mecanismo inflamatorio que subyace en el asma 


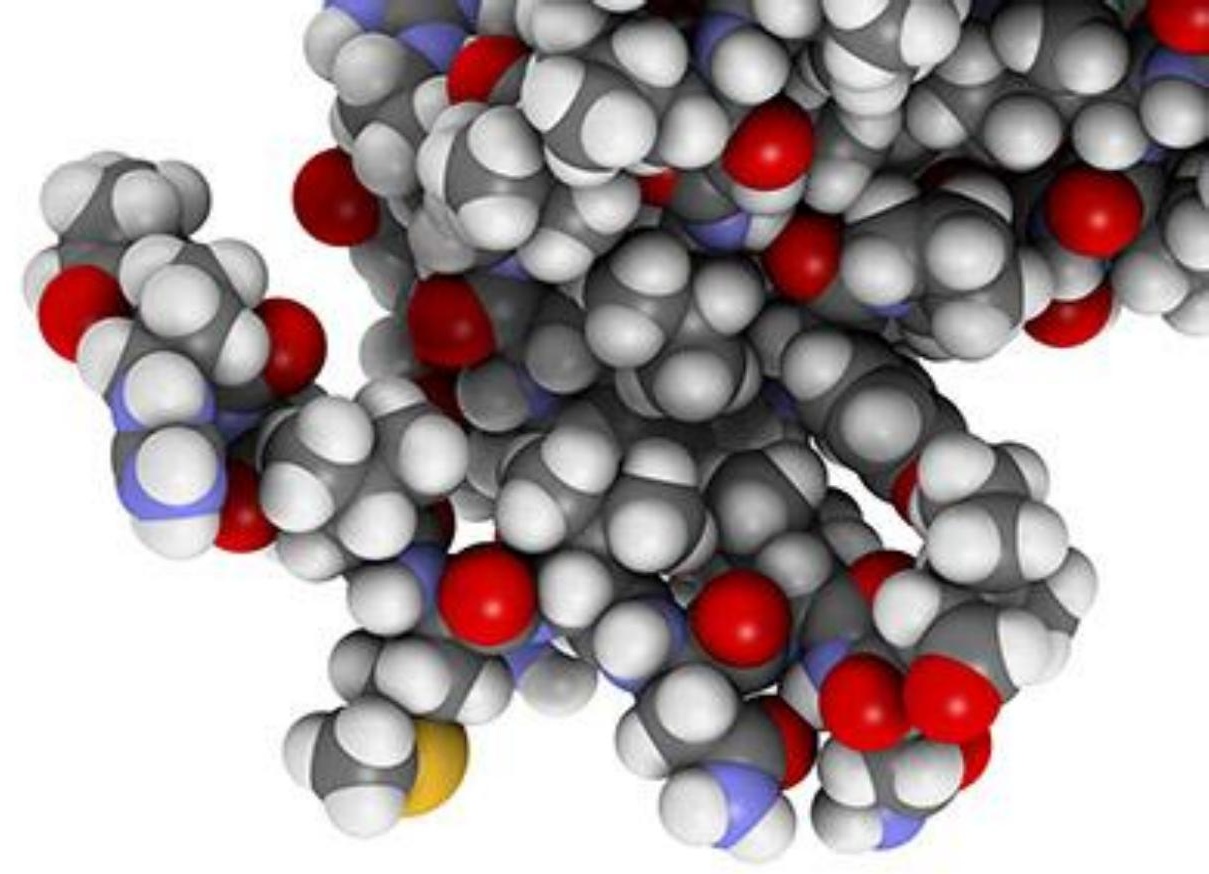

ÍNDICE DE FIGVRAS 



\section{0. ÍNDICE DE FIGURAS}

Figura 1: Publicación de Thomas Addison en 1855..

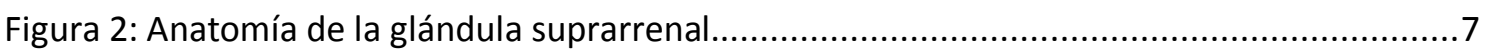

Figura 3: Sistema básico de regulación del eje hipotálamo-hipófisis-suprarrenal. ......................9

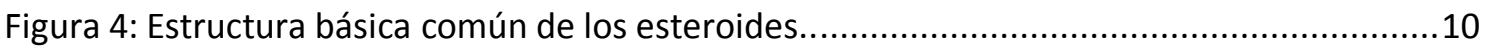

Figura 5: Estructura molecular de algunos corticoides naturales y sintéticos. ..........................11

Figura 6: Localización del gen del receptor de glucocorticoide en el cromosoma 5 .................14

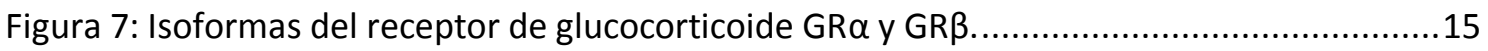

Figura 8: Estructura esquemática del receptor de glucocorticoides. .......................................16

Figura 9: Activación del receptor de glucocorticoide por unión del ligando. ............................17

Figura 10: Acción del GR a través de los elementos de respuesta a glucocorticoide..................20

Figura 11: Interacción entre la activación de GR y la inhibición de MAPK................................24

Figura 12: Papel del GR en la regulación del proceso apoptótico... ….......................................28

Figura 13: Papel del eosinófilo en la respuesta inmunitaria. ......................................................32

Figura 14: Papel del linfocito Th2 en la inflamación asmática. ...............................................33

Figura 15: Implicación de las células epiteliales en el desarrollo del asma...............................34

Figura 16: Escalones terapéuticos en el tratamiento del asma..............................................39

Figura 17: Activación de mastocito por complejo IgE-alérgeno...............................................49

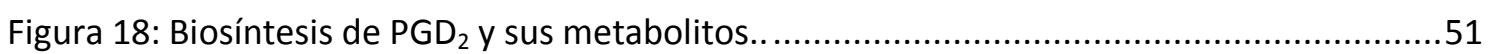

Figura 19: Mecanismo de acción de los dos receptores de prostaglandina $\mathrm{D}_{2} \ldots \ldots \ldots \ldots \ldots \ldots \ldots . . . . . . . . . . . . .52$

Figura 20: Localización del gen PTGDR dentro del cromosoma 14. .....................................57

Figura 21: Ejemplo de estructura de receptor acoplado a proteína $G$ con siete dominios

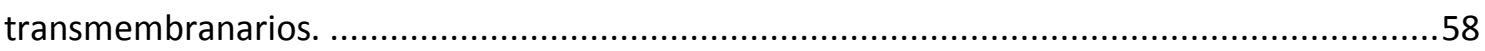

Figura 22: Árbol filogenético de los receptores de prostaglandinas en seres humanos (h) y

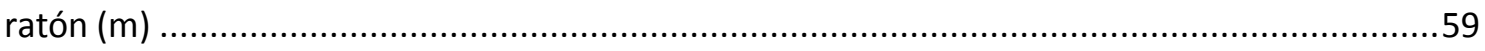

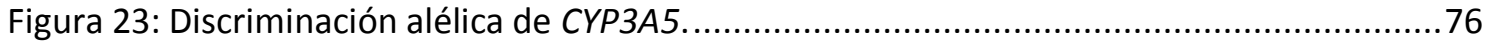

Figura 24: Marcador de peso molecular Marker VIII (Gel de agarosa 2\%). ...............................82

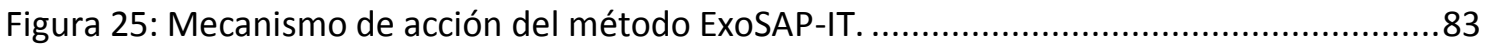

Figura 26: Ejemplo de curva para el cálculo de eficiencia para los cebadores de GAPDH humano

Figura 27: Secuencia del amplicón de PTGDR utilizado para la creación de los vectores específicos.

Figura 28: Esquema del vector pSC-A-amp/kan, utilizado para la clonación de los productos de PCR. 


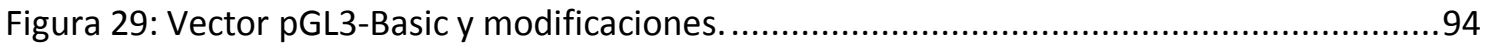

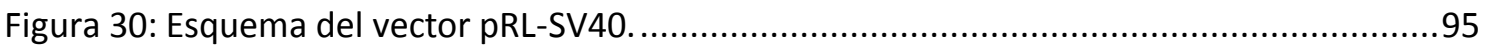

Figura 31: Construcción de vectores de expresión de PTGDR ..............................................96

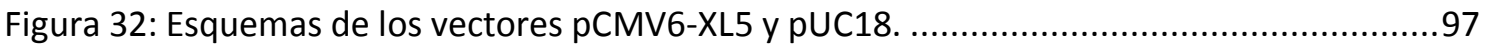

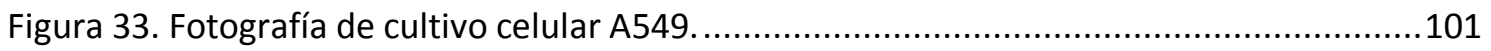

Figura 34: Planificación del ensayo para medir la actividad promotora con luciferasa. ..........111

Figura 35: Reacción química llevada a cabo por la luciferasa de luciérnaga............................112

Figura 36: Reacción química llevada a cabo por la Renilla luciferasa.......................................112

Figura 37: Planificación del ensayo para medir la expresión génica con vectores de expresión.

Figura 38: Sistema de reconocimiento de citocinas mediante conjugación con anticuerpos y sistema de doble láser.

Figura 39: Grupos de tratamiento en el modelo experimental múrido de asma alérgica.

Figura 40: Análisis mediante PCR a tiempo real del nivel de expresión de CYP3A5 en respuesta al tratamiento corticoideo. 129

Figura 41: Actividad promotora de PTGDR tras 12 y 36 horas de cultivo. 131

Figura 42: Efecto de las variantes polimórficas de PTGDR sobre su actividad promotora.

Figura 43: Actividad promotora de las cuatro variantes polimórficas de PTGDR en condición basal sin tratamiento y con etanol.

Figura 44: Efecto del tratamiento con dexametasona en la actividad promotora de las cuatro variantes polimórficas de PTGDR.

Figura 45: Nivel de actividad promotora tras el tratamiento con dexametasona. 135

Figura 46: Análisis mediante PCR a tiempo real del nivel de expresión de PTGDR según la combinación haplotípica de su promotor tras 12 y 36 horas de cultivo.

Figura 47: Comparación mediante PCR a tiempo real de los niveles de expresión de PTGDR en células no tratadas y células tratadas con etanol.

Figura 48: Comparación mediante PCR a tiempo real de los niveles de expresión de PTGDR en células tratadas con dexametasona y células tratadas con etanol.

Figura 49: Diferencia de expresión de PTGDR entre el tratamiento con dexametasona y con el vehículo (etanol) tras12 horas de exposición.

Figura 50: Diferencia de expresión de PTGDR entre el tratamiento con dexametasona y con el vehículo (etanol) tras 36 horas de exposición. 142

Figura 51: Influencia de la presencia de distintas combinaciones polimórficas en el promotor de PTGDR sobre el nivel de citocinas en células A549 tras 12 horas de cultivo. 148 
Figura 52: Influencia de la presencia de distintas combinaciones polimórficas en el promotor de PTGDR en el nivel de citocinas en células A549 tras 36 horas de cultivo. 151

Figura 53: Efecto de la dexametasona sobre el nivel de IP-10 tras 12 horas de tratamiento...154

Figura 54: Efecto de la dexametasona sobre el nivel de RANTES tras 12 horas de tratamiento. 155

Figura 55: Efecto de la dexametasona sobre el nivel de MIP-1 $\beta$ tras 12 horas de tratamiento. 156

Figura 56: Efecto de la dexametasona sobre el nivel de IL-12 tras 12 horas de tratamiento...157 Figura 57: Efecto de la dexametasona sobre el nivel de VEGF tras 12 horas de tratamiento. .157 Figura 58: Efecto de la dexametasona sobre el nivel de IL-6 tras 12 horas de tratamiento.....158 Figura 59: Efecto de la dexametasona sobre el nivel de IL-8 tras 12 horas de tratamiento.....159 Figura 60: Efecto de la dexametasona sobre el nivel de MCP-1 tras 36 horas de tratamiento.

Figura 61: Efecto de la dexametasona sobre el nivel de Eotaxina tras 36 horas de tratamiento.

Figura 62: Efecto de la dexametasona sobre el nivel INF- $\gamma$ tras 36 horas de tratamiento. 162

Figura 63: Efecto de la dexametasona sobre el nivel de MIP-1b tras 36 horas de tratamiento. 163

Figura 64: Efecto de la dexametasona sobre el nivel de VEGF tras 36 horas de tratamiento. .164 Figura 65: Efecto de la dexametasona sobre el nivel IL-12 tras 36 horas de tratamiento.........164 Figura 66: Efecto de la dexametasona sobre el nivel de IL-6 tras 36 horas de tratamiento.....165 Figura 67: Efecto de la dexametasona sobre el nivel de IL-8 tras 36 horas de tratamiento.....166 Figura 68: Análisis mediante PCR a tiempo real de la expresión de PTGDR en un modelo crónico de asma alérgica en ratón. 167 
Efecto de la dexametasona sobre el mecanismo inflamatorio que subyace en el asma 



\section{ABREVIATURAS}

A: Adenina

AA: Ácido araquidónico

AC: Adenilato ciclasa

ACTH: Hormona adrenocorticotropa o corticotropina

ADN: Ácido desoxirribonucleico

ADNc: ADN complementario

AF: Dominio de transactivación

AGNC: Asma grave no controlada

AMP: Adenosín monofosfato

Amp: Amplicilina

AMPc: Adenosín monofosfato cíclico

ANOVA: Análisis de la varianza

AP-1: Activator protein 1

AQP: Acuoporina

ARLT: Antagonista del receptorde leucotrienos

ARN: Ácido ribonucleico

ARNm: ARN mensajero

ARNr: ARN ribosómico

ATCC: American Type Culture Collection
ATP: Adenosín trifosfato

ATS: American Thoracic Society.

B: Biotina

BAL: Lavado broncoalveolar

FGF: Factor de crecimiento de fibroblastos

BD: Budenosida

BLAST: Basic Local Alingment Search Tool

C: Citosina

Cfu: Unidades formadoras de colonias

CMV: Citomegalovirus

COX: Ciclooxigenasa

CRF: Factor liberador de corticotropina

CRHT2: Molécula homóloga de receptor quimiotáctico extresada en células Th2

CRM1: Exportina 1 (XPO1)

Ct: Threshold Cycle. Ciclo umbral CYP: Citocromo p450

Da: Dalton

DBD: Dominio de unión al ADN 
Dexa: Dexametasona

DMSO: Dimetil sulfóxido

dNTP: Desoxirribonucleotido trifosfato

DOPE: Dioleoyl

phosphatidylethanolamine

DOSPA: 2,3-dioleyloxy-N-

[2(sperminecarboxamido)ethyl]-

N,Ndimethyl-1-propanaminium

trifluoroacetate

DPB: Dipropionato de beclometasona

DTT: Ditiotreitol

EDTA: Ácido etilendiaminotetraacético

EEUU: Estados Unidos

EPOC: Enfermedad pulmonar

obstructiva crónica

ERS: European Respiratory Society.

EtOH: Etanol

Exol: Exonucleasa I

FEV1: Volumen espirado máximo en el primer segundo de la espiración forzada

FKBP: Proteína de unión a FK506

FVC: Capacidad vital forzada
GAPDH: Gliceraldehido-3-fosfato

deshidrogenasa

GC: Glucocorticoide

GCI: Glucocorticoide inhalado

GCS: Glucocorticoide sistémico

G-CSF: Factor estimulante de colonias de granulocitos

GEMA: Guía Española para el Manejo del Asma

GILZ: Glucocorticoid-induce leucine zipper

GINA: Global Initiative for Asthma

GM-CSF: Factor estimulante de colonias de granulocitos y monocitos

GR: Receptor de glucocorticoide

GRE: Elemento de respuesta a los corticoides

GWAS: Genome-wide association study

HAT: Histona acetiltransferasa

HDAC: Histona deacetilasa

H-PGDS: Sintasa hematopoyética de prostaglandina $D_{2}$

HRM: High Resolution Melt.

G: Guanina 
Hsp: Heat shock protein. Proteína de shock térmico.

ICAM: Molécula de adhesión

intercelular

IFN: Interferón

IgE: Inmunoglobulina $\mathrm{E}$

IGF: Factor de crecimiento insulínico

IL: Interleucina

IN: Intranasal

iNOS: Sintasa de óxido nítrico inducible

IP: Intraperitoneal

IP-10: Proteína 10 inducida por

interferón

Kan: Kanamicina

$\mathbf{K b}$ : kilobase

kDa: kilo Dalton

LABA: $\beta$-adrenérgicos de acción larga

LBD: Dominio de unión al ligando

L-PGDS: Sintasa de prostaglandina $\mathrm{D}_{2}$ tipo lipocalina

LPS: Lipopolisacáridos

Luc: Luciferasa

MAP: Mitogen-activated protein
MAPK: cinasa de MAP

MCP: Proteína quimioatrayente de monocitos

MIP: Proteina inflamatoria de macrófagos.

MKP: MAPK fosfatasa

N: Nucleótido

NF-kB: Nuclear factor kappa beta

NLS: Secuencia de localización nuclear

NO: Óxido nítrico

NRS: Señal de retención nuclear

NTD: Dominio amino-terminal

NVP: Núcleo paraventricular

OVA: Ovoalbúmina

$\mathrm{Pb}$ : Pares de bases.

PBMC: Célula mononuclear de sangre periférica

PBS: Buffer fosfato salino

PCR: Reacción en cadena de la polimerasa

PE: Ficoeritrina

PF: Propionato de fluticasona

$\mathrm{PGD}_{2}$ : Prostaglandina $\mathrm{D}_{2}$ 
$\mathrm{PGE}_{2}$ : Prostaglandina $\mathrm{E}_{2}$

$\mathbf{P G F}_{2}$ : Prostaglandina $\mathrm{F}_{2}$

$\mathbf{P G G}_{2}$ : Prostaglandina $\mathrm{G}_{2}$

$\mathbf{P G H}_{2}$ : Prostaglandina $\mathrm{H}_{2}$

$\mathrm{PGI}_{2}$ : Prostaglandina $\mathrm{I}_{2}$

PKA: Proteína kinasa A kinasa o cinasa?

PLA $A_{2}$ Fosfolipasa $A_{2}$

PTGDR: Receptor de la prostaglandina

$D_{2}$. También llamado DP o DP1.

Pu: Purina

Py: Pirimidina

qPCR: PCR cuantitativa

RANTES: Regulated on Activation,

Normal T Cell Expressed and Secreted,

(CCL5)

RIN: RNA integrity number

RNApolII: RNA polimerasa III

ROS: Especies reactivas del oxígeno

Rpm: Revoluciones por minuto

Rs: Número de referencia de

polimosrfismos

RT-PCR: Reacción en cadena de la

polimerasa con transcriptasa inversa

RXR: Retinoid X receptor
S: Estreptavidina

SAP: Fosfatasa alcalina

SFB: Suero fetal bovino

T: Timina

TAF: Factor asociado de transcripción

TF: Factor de transcripción

TFRE: elemento de respuesta a factor de transcripción

TNF: Factor de necrosis tumoral

TSH: Tirotropina, Hormona estimulante del tiroides

TXA $A_{2}$ :Tromboxano $A_{2}$

TXB $_{2}$ : Tromboxano $\mathrm{B}_{2}$

URL: Unidades relativas de luciferasa

VCAM: Molécula de adhesión vascular

VEGF: Factor de crecimiento del

endotelio vascular

VRS: Virus respiratorio sincitial 